\title{
ISSN 2411-1562
}

\section{INSTITUTUM PHILOLOGIAE}

CATHEDRA LINGUISTICAE GENERALIS, PHILOLOGIAE CLASSICAE ET NEOHELLENISTICAE

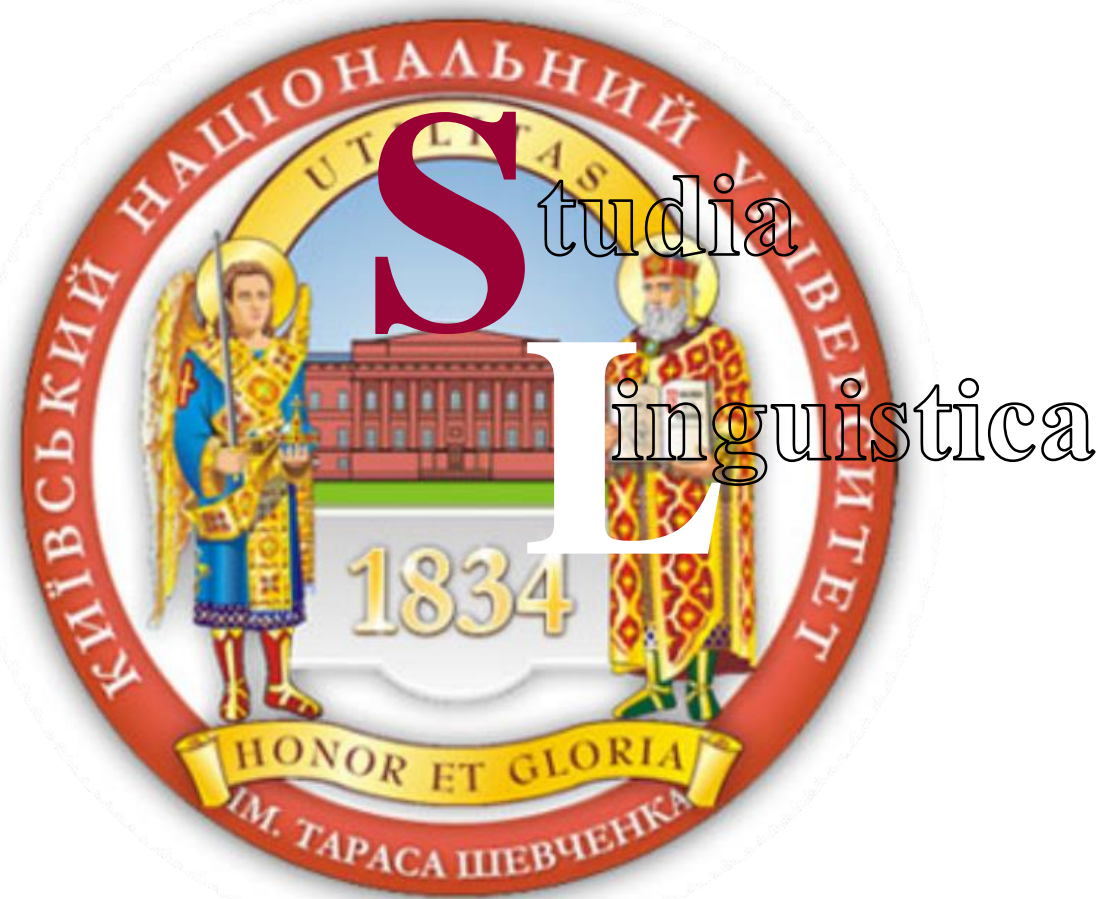

http://philology.knu.ua/node/316 http://pinax.com.ua 
ISSN 2411-1562

У рамках тринадцятого тому збірника наукових праць "Studia Linguistica" представлені наукові праці вчених, присвячені різним проблемам мовознавства, когнітивної лінгвістики, лінгвокультурології та етнолінгвістики, які осмислюються у річищі найсучасніших лінгвістичних ідей.

Within the framework of the thirteenth volume of the collection of scientific works "Studia Linguistica" the scientific articles of scholars devoted to the solution of various problems of modern theoretical linguistics, cognitive linguistics, cultural linguistics and ethnolinguistics are being presented.

Орієнтований на наукових працівників, викладачів, студентів, аспірантів.

Addressed to researchers, teachers, graduate and post-graduate students.

Адреса редколегії

Address of the Editorial Board

\section{Рекомендовано}

Recommended

Атестовано

Certified

Зареєстровано

Registered

Засновник

Founder

Відповідальні за випуск

Responsible for the issue
01601, м. Київ, 6-р Шевченко, 14, к. 141

? (+38044) 23934 15, zagmoclasphil@gmail.com

Збірник розміщено на сайтах:

http://philology.knu.ua/node/316; http://pinax.com.ua

01601, Kyiv, boulevard Shevchenko, 14, room 141

\& (+38044) 23934 15, zagmoclasphil@gmail.com

The collection of scientific works is presented on the website:

http://philology.knu.ua/node/316; http://pinax.com.ua

Вченою радою Інституту філології КНУ імені Тараса Шевченка від 28.11.2018 (протокол № 4)

By Academic Council of Institute of Philology of Taras Shevchenko National University of Kyiv on November, 28, 2018 (protocol № 4)

Вищою атестаційною комісією України.

Постанова Президії ВАК України № 747 від 13.07.2015

By State Accreditation Committee of Ukraine

Decree of the Presidium of the SAC of Ukraine № 747 dated 13.07.2015

Міністерством юстиції України

Свідоцтво про державну реєстрацію КВ № 13518-2402Р від 09.11 .2007

By Ministry of Justice of Ukraine Certificate of registration KB № 13518-2402P dated 09.11.2007

Київський національний університет імені Тараса Шевченка

Taras Shevchenko National University of Kyiv

О. В. Левко, А. філол. наук., доц., О. Ю. Галкіна, ст. лаборант

O. v. Levko, D. of Philol., Associate Prof., 0. Yu. Galkina, laboratory assistant

Автори опублікованих матеріалів несуть повну відповідальність за підбір, точність наведених фактів, цитат, економіко-статистичних даних, відповідної галузевої термінології, власних імен та інших відомостей. Редколегія залишає за собою право скорочувати та редагувати подані матеріали.

The authors of the published materials are fully responsible for the selection, accuracy of the facts, quotes, economic and statistical data, relevant terminology, proper names and other information. The editorial board reserves the right to shorten and edit the submitted materials. 


\section{Редакційна колегія \\ періодичного видання "Studia Linguistica" \\ Information about the members of the Editorial Board \\ of the periodical "Studia Linguistica"}

Відповідальний редактор

Responsible Editor

\author{
Голубовська \\ Ірина Олександрівна \\ доктор філологічних наук, професор
}

Iryna Golubovska

Doctor of Philology, Professor

Заступник відповідального редактора

Deputy Editor-in-Chief

Звонська

Леся Леонідівна

доктор філологічних наук, професор

Lesia Zvons'ka

Doctor of Philology, Professor

\section{Відповідальні секретарі}

Responsible Secretaries

\author{
Корольов \\ Ігор Русланович \\ кандидат філологічних наук, доцент, \\ докторант

\section{Ihor Korol'ov} \\ Ph.D in Philology, Doctoral Candidate
}

\section{Левко}

Олександр Вадимович

кандидат філологічних наук, доцент
Київський національний університет імені Тараса Шевченка, Інститут філології, завідувач кафедри загального мовознавства, класичної філології та неоелліністики

Taras Shevchenko National University of Kyiv, Institute of Philology, Head of the Department of General Linguistics, Classical Philology and Neoellinistics

Київський національний університет імені Тараса Шевченка, Інститут філології, професор кафедри загального мовознавства, класичної філології та неоелліністики

Taras Shevchenko National University of Kyiv, Institute of Philology, Professor of the Department of General Linguistics, Classical Philology and Neoellinistics

Київський національний університет імені Тараса Шевченка, Інститут філології, докторант кафедри загального мовознавства, класичної філології та неоелліністики

Taras Shevchenko National University of Kyiv, Institute of Philology, Ph.D. in Philology, Doctoral Candidate

Київський національний університет імені Тараса Шевченка, Інститут філології, доцент кафедри загального мовознавства, класичної філології та неоелліністики 
Olexandr Levko

Ph.D in Philology

Associate Professor

Руда

Наталя Вікторівна

кандидат філологічних наук

\section{Natalia Ruda}

Ph.D in Philology, Assistant Professor

Члени редакційної колегії

Members of the Editorial Board

\author{
Архангельська \\ Алла Мстиславівна
}

доктор філологічних наук, професор

Alla Arkhangelska

Doctor of Philology, Professor

\section{Бартмінський Єжі}

Академік Польської Академії мистецтв і наук, доктор філологічних наук, професор

Bartmiński Jerzy

Academician of the Polish Academy of Arts and Sciences, Doctor of Philology, Professor

\section{Бацевич \\ Флорій Сергійович}

доктор філологічних наук, профессор

Florii Batsevych

Doctor of Philology, Professor
Taras Shevchenko National University of Kyiv, Institute of Philology, Associate Professor of the Department of General Linguistics, Classical Philology and Neoellinistics

Київський національний університет імені Тараса Шевченка, Інститут філології, асистент кафедри загального мовознавства, класичної філології та неоелліністики

Taras Shevchenko National University of Kyiv, Institute of Philology, Assistant Professor of the Department of General Linguistics, Classical Philology and Neoellinistics

Університет ім. Ф. Палацького в Оломоуці (Чехія), професор кафедри славістики

University of the F. Palacki in Olomouc (Czech Republic), Professor of the Department of Slavic Studies

Люблінський університет Марії КюріСклодовської (Польща), гуманітарний факультет, директор Етнолінгвістичного Архіву Інституту польської філології

Lublin University Maria CurieSclodowska (Poland), Faculty of Humanities, Director of the Ethnolinguistic Archive of the Institute of Polish Philology

Львівський національний університет імені Івана Франка, завідувач кафедри загального мовознавства

Lviv Ivan Franko National University, Head of the Department of General Linguistics 
Броджі Джованна

доктор філологічних наук, професор

\section{Brogi Giovanna}

Doctor of Philology, Professor

Гарзаніті Марчелло

доктор філологічних наук, професор

Garzaniti Marcello

Doctor of Philology, Professor

\section{Єрмоленко \\ Сергій Семенович}

доктор філологічних наук, професор

Serhii Yermolenko

Doctor of Philology, Professor

Загнітко Анатолій Панасович

Член-кореспондент НАН України, доктор філологічних наук, професор

\section{Anatolii Zahnitko}

Corresponding Member of the National Academy of Sciences of Ukraine, Doctor of Philology, Professor

\begin{tabular}{c} 
Клименко \\
Ніна Федорівна \\
Член-кореспондент НАН України, доктор \\
філологічних наук, професор \\
\hline
\end{tabular}

Міланський університет (Італія), факультет літератури i філософії, завідувач кафедри лінгвістичних, літературних і філологічних студій

University of Milan (Italy), Faculty of Literature and Philosophy, Head of the Department of Linguistic, Literary and Philological Studies

Флорентійський університет (Італія), факультет мов, літератур та міжкультурних досліджень, професор кафедри лінгвістичних студій та сходознавства, Президент Італійської Асоціації славістів

Florentine University (Italy), Faculty of Languages, Literature and Intercultural Studies, Professor of the Department of Linguistic and Oriental Studies, President of the Italian Association of Slavists

Інститут мовознавства імені О. О. Потебні НАН України, провідний науковий співробітник відділу загального мовознавства

O. O. Potebnia Institute of Linguistics (National Academy of Sience of Ukraine), Leading Researcher of the Department of General Linguistics

Донецький національний університет імені Василя Стуса, завідувач кафедри загального і прикладного мовознавства та слов'янської філології

Vasyl' Stus Donetsk National University, Head of the Department of General and Applied Linguistics and Slavic Philology

Київський національний університет імені Тараса Шевченка, Інститут філології, професор кафедри загального мовознавства, класичної філології та неоелліністики 


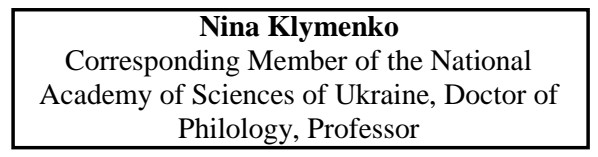

Корнілов

Олег Олександрович

доктор культурології, професор

Oleh Kornilov

Doctor of Cultural Studies, Professor

Лучканин

Сергій Мирославович

доктор філологічних наук, професор

\author{
Serhii Luchkanyn \\ Doctor of Philology, Professor
}

Манакін
Володимир Миколайович
доктор філологічних наук, професор

Volodymyr Manakin

Doctor of Philology, Professor

Миронова Валентина Миколаївна

кандидат філологічних наук, доцент

Valentyna Myronova

Ph.D in Philology, Associate Professor
Taras Shevchenko National University of Kyiv, Institute of Philology, Professor of the Department of General Linguistics, Classical Philology and Neoellinistics

Московський державний університет імені М. В. Ломоносова (Росія), факультет іноземних мов та регіонознавства, професор кафедри порівняльного вивчення національних літератур і культур

Mykhailo Lomonosov Moscow State University (Russia), Faculty of Foreign Languages and Regional Studies, Professor of the Department of Comparative Study of National Literatures and Cultures

Київський національний університет імені Тараса Шевченка, Інститут філології, доцент кафедри загального мовознавства, класичної філології та неоелліністики

Taras Shevchenko National University of Kyiv, Institute of Philology, Professor of the Department of General Linguistics, Classical Philology and Neoellinistics

Запорізький національний університет, декан факультету журналістики, завідувач кафедри видавничої справи та редагування

Zaporizhzhya National University, Dean of the Faculty of Journalism, Head of the Department of Publishing and Editing

Київський національний університет імені Тараса Шевченка, Інститут філології, доцент кафедри загального мовознавства, класичної філології та неоелліністики

Taras Shevchenko National University of Kyiv, Institute of Philology, Associate Professor of the Department of General Linguistics, Classical Philology and Neoellinistics 
Мосенкіс Юрій
Леонідович

доктор філологічних наук, професор

Yurii Mosenkis

Doctor of Philology, Professor

Нікітіна Фіонілла Олексіївна

доктор філологічних наук, професор

Fionilla Nikitina

Doctor of Philology, Professor

Снитко Олена

Степанівна

доктор філологічних наук, професор

Olena Snytko

Doctor of Philology, Professor

Тищенко

Олег Володимирович

доктор філологічних наук, професор

Oleh Tyshchenko

Doctor of Philology, Professor

Черниш

Тетяна Олександрівна

доктор філологічних наук, професор

Tetiana Chernysh

Doctor of Philology, Professor
Київський національний університет імені Тараса Шевченка, Інститут філології, професор кафедри української мови та прикладної лінгвістики

Taras Shevchenko National University of Kyiv, Institute of Philology, Professor of the Department of Ukrainian Language and Applied Linguistics

Національний педагогічний університет імені М.П. Драгоманова, Інститут іноземної філології, професор, завідувач кафедри англійської філології

Mykhailo Drahomanov National Pedagogical University, Institute of Foreign Philology, Professor, Head of the Department of English Philology

Київський національний університет імені Тараса Шевченка, Інститут філології, завідувач кафедри російської філології

Taras Shevchenko National University of Kyiv, Institute of Philology, Head of the Department of Russian Philology

Львівський державний університет безпеки життєдіяльності, завідувач кафедри перекладу

Lviv State University of Life Safety, Head of the Department of Translation

Київський національний університет імені Тараса Шевченка, Інститут філології, професор кафедри слов'янської філології

Taras Shevchenko National University of Kyiv, Institute of Philology, Professor of the Department of Slavic Philology 


\section{Чемес \\ Валерій Федорович}

кандидат філологічних наук, доцент

Valerii Chemes

Ph.D in Philology, Associate Professor

Шовковий

В'ячеслав Миколайович

доктор педагогічних наук, професор

V'iacheslav Shovkovyi

Doctor of Pedagogical Sciences, Professor

Hui Ching Chang

Ph.D., Associate Professor

Хуей Чін Чан,

кандидат філологічних наук, доцент

Michael A. Denner

Ph.D., Associate Professor

Мішель А. Деннер,

кандидат філологічних наук, доцент
Київський національний університет імені Тараса Шевченка, Інститут філології, доцент кафедри загального мовознавства, класичної філології та неоелліністики

Taras Shevchenko National University of Kyiv, Institute of Philology, Associate Professor of the Department of General Linguistics, Classical Philology and Neoellinistics

Київський національний університет імені Тараса Шевченка, Інститут філології, завідувач кафедри методики викладання української та іноземної мов та літератур

Taras Shevchenko National University of Kyiv, Institute of Philology, Head of the Department of Methods of Teaching Ukrainian and Foreign Languages and Literatures

University of Illinois at Chicago, Professor at the Communicative Department

Іллінойський Університет в Чікаго, доцент кафедри комунікативістики

Stetson University (DeLand, Florida)

Stetson's Program in Russian, East European and Eurasian Studies Director, University Honors Program Director, Editor of Tolstoy Studies Journal

Стетсонський університет (ДеЛанд, Флорида). Директор програми російських, східно-європейських та євразійських студій, директор почесних програм Стетсонського університету, редактор журналу «Толстовські студії» 


\title{
RESEARCH PROJECT
}

\section{LANGUAGE AND DISCOURSE PRACTICES OF WORLD MEDIA IN THE CONTEXT OF AXIOLOGICAL DOMINANTS' CHANGE}

\author{
Golubovska Iryna, igolubovska777@gmail.com \\ Doctor of Science, Full prof. \\ Taras Shevchenko National University of Kyiv, \\ Institute of Philology
}

\section{Darchuk Natalia, nataliadarchuk@gmail.com \\ Doctor of Science, Full prof. \\ Taras Shevchenko National University of Kyiv, Institute of Philology}

\section{Chernenko Hanna, hanna.chernenko@gmail.com \\ Ph.D., Associate prof. \\ Taras Shevchenko National University of Kyiv, \\ Institute of Philology}

The main problem the present project addresses is the development of an integrated approach to diachronically oriented study of the main sociocultural values based on semiotic oppositions: culture / nature; materialistic / spiritual; joy / grief; health / illness; beauty / deformity, which involves the development of linguocognitive and linguoculturological methods on the material of fine arts' and media texts based on the identification of verbal and non-verbal markers of value dominants what contributes to the formation of a postmodernist model of the world examined in the veine of new cultural values and anti-values emergence.

The working hypothesis of the project is that the study of lingual and discursive reflexes of the changes in values of the modern society, made with the help of corpus data on the material of the European languages, will reveal the main features of the modern world conceptual system based on the common for many ethnic groups (at least European) systems of values and anti-values.

The goal of the project might be put as working out of an algorithm for analyzing the process of changing of axiological orientations of a society, which will be carried out on the material of fiction and media texts on the grounds of a corpus-based approach to the processing language data.

The relevance of such a research is due to the lack of systemic studies of this kind both in domestic linguistics and abroad: so far there are no studies within which an attempt is made to investigate changes in the axiosphere of modern society on the

Дослідницький проект [Исследовательский проект]

(С) Голубовська І. О., Дарчук Н. П., Черненко А. А. [Голубовская И. А., Дарчук Н. П., Черненко А. А.], igolubovska777@gmail.com,nataliadarchuk@gmail.com, hanna.chernenko@gmail.com Мова і дискурсивні практики світового медіапростору у контексті змін аксіологічних домінант [Язык и дискурсивные практики мирового медиапространства в контексте изменений аксиологических доминант] (Українською / На укр. яз) 
material of many European languages practicing the corpus approach to processing cultural and speech data and highlightening both global and national-specific values inherent for this or that linguoculture.

The study will be anthropocentrically oriented, as well as a set of neolinguistic approaches to processing lexical, phraseological and grammatical innovations in media (which will be considered in linguocognitive, linguo cultural, linguopragmatic, discursive and suggestive aspects) would be exercised.

Predicted results might significantly affect the empowerment of human selfreflection in the context of identifying axiological attitudes that speakers both intentionally and unwittingly broadcast in their daily communicative practices (many of them are being formed just by media and fiction texts). This is extremely important in the context of the informational wars, when there is a need to increase the level of mass media texts' critical perception, the last very often appear to be an instrument of political propaganda.

\section{ИССЛЕДОВАТЕЛЬСКИЙ ПРОЕКТ}

\section{ЯЗЫК И ДИСКУРСИВНЫЕ ПРАКТИКИ МИРОВОГО МЕДИАПРОСТРАНСТВА В КОНТЕКСТЕ ИЗМЕНЕНИЙ АКСИОЛОГИЧЕСКИХ ДОМИНАНТ}

\section{Голубовская Ирина Александровна, igolubovska777@gmail.com}

д. филол. наук, проф.

Киевский национальный университет имени Тараса Шевченко, Институт филологии

Дарчук Наталья Петровна, nataliadarchuk@gmail.com д. филол. наук, проф.

Киевский национальный университет имени Тараса Шевченко, Институт филологии

\section{Черненко Анна Анатольевна, hanna.chernenko@gmail.com}

к. филол. наук, доц.

Киевский национальный университет имени Тараса Шевченко Институт филологии

Основная проблема, на разрешение которой будет направлен проект,разработка комплексного подхода к диахронно ангажированному изучению базовых социокультурных ценностей на основе семиотических оппозиций: культура / природа; материальное / духовное; радость / горе; здоровье / болезнь; красота / уродство, который предусматривает разработку методики 
лингвокогнитивного и лингвокультурологического анализа художественных и медиатекстов на основе выделения вербально-невербальных маркеров ценностных доминант, способствующих формированию постмодернистской картины мира в аспекте возникновения новых культурных ценностей и антиценностей.

Рабочая гипотеза проекта будет заключаться в том, что исследование языковых и дискурсивных рефлексов изменений в ценностных установках современного нам общества, сделанное с привлечением корпусных данных на материале языков «среднеевропейского стандарта», обнаружит основные черты новой концептуальной картины мира современности на основе определения общей для многих этносов (по крайней мере европейских) системы ценностей и антиценностей.

Цель проекта можно сформулировать как создание алгоритма анализа процесса изменений аксиологических ориентаций общества, который будет осуществлен на материале художественных и медиатекстов с привлечением корпусного подхода к разработке языковых данных.

Актуальность такого рода исследования обусловлена отсутствием системных исследований такого рода как в отечественной лингвистике, так и за рубежом, поскольку пока не существует исследований, в рамках которых была бы предпринята попытка исследовать изменения в аксиосфере современного общества на материале многих европейских языков с привлечением корпусного подхода к обработке культурно-речевых данных и выделения при этом как глобальных, так и национально-специфических ценностей, присущих отдельным лингвокультурам.

В основу этого исследования будет положен антропоцентрический подход, а также комплекс неолингвистических подходов к толкованию лексико-фразеологических и лексико-грамматических инноваций в медиа, которые будут рассматриваться в лингвокогнитивном, лингвокультурологическом, лингвопрагматическом, дискурсивном, суггестивном аспектах.

Прогнозируемые результаты могут существенно повлиять на расширение возможностей саморефлексии человека в контексте выявления аксиологических установок, которые говорящие умышленно или невольно транслируют в своей повседневной коммуникации (многие из них формируют именно медиа- и художественные тексты). Это крайне важно в условиях информационной, консциентальной войны, когда существует потребность в повышении уровня критического восприятия массмедийных текстов, которые очень часто выступают орудием политической пропаганды.

Дослідницький проект [Исследовательский проект] (С) Голубовська І. О., Дарчук Н. П., Черненко А. А. [Голубовская И. А., Дарчук Н. П., Черненко А. А.], igolubovska777@gmail.com,nataliadarchuk@gmail.com, hanna.chernenko@gmail.com Мова і дискурсивні практики світового медіапростору у контексті змін аксіологічних домінант [Язык и дискурсивные практики мирового медиапространства в контексте изменений аксиологических доминант] (Українською / На укр. яз) 


\section{ДОСЛІДНИЦЬКИЙ ПРОЕКТ}

\section{МОВА І ДИСКУРСИВНІ ПРАКТИКИ СВІТОВОГО МЕДІАПРОСТОРУ У КОНТЕКСТІ ЗМІН АКСІОЛОГІЧНИХ ДОМІНАНТ}

Голубовська Ірина Олександрівна, igolubovska777@gmail.com

д. філол. наук, проф.

Київський національний університет імені Тараса Шевченка, Інститут філології

Дарчук Наталія Петрівна, nataliadarchuk@ gmail.com

д. філол. наук, проф.

Київський національний університет імені Тараса Шевченка, Інститут філології

\section{Черненко Анна Анатоліївна, hanna.chernenko@gmail.com к. філол. наук, доц. \\ Київський національний університет імені Тараса Шевченка Інститут філології}

Будь-яка нова епоха породжує певний набір життєвих цінностей, які виформовують нову норму міжлюдських стосунків, новий стиль та образ життя, у кінцевому рахунку - нові світоспоглядальні соціально заангажовані орієнтири людського буття. Сучасна епоха постмодерну тут i зараз визначає особливий характер життєвих цінностей, вносить суттєві коректури в їх ієрархію і змістове наповнення. При цьому художній дискурс та засоби масової інформації - 3MI, які у новому постіндустріальному суспільстві стають універсальною формою отримання знання про соціально-політичне життя глобалізованого суспільства, пропонують певну ієрархію ціннісних смислів, нові психоповедінкові моделі, тим самим суттєво впливаючи на трансформацію аксіологічної сфери того чи того соціуму. При цьому нові аксіологічні домінанти далеко не завжди спрямовані на консолідацію суспільства: часто-густо вони набувають руйнівної, деструктивної якості, характеру соціокультурної антицінності. Таким чином, великої значущості у наш карколомний час набуває відстеження змін в аксіологічній сфері 
суспільства на основі вивчення мовних, мовленнєвих та дискурсивних інновацій, що ефективно можна здійснювати із залученням лінгвоінформаційних технологій корпусів мов (зокрема Корпусу української мови, створеного фахівцями КНУ імені Тараса Шевченка під керівництвом професора Наталії Дарчук (www.mova.info), потужного комп'ютерного ресурсу, який надає можливість на основі системи підкорпусів медіатекстів, художньої прози, поезії, наукових текстів проводити лінгвістичну експертизу, у тому числі й відносно змін аксіологічних суспільних орієнтацій.

Основна проблема, на яку буде спрямовано проект, - розроблення комплексного підходу до діахронно заангажованого вивчення базових соціокультурних цінностей на основі семіотичних опозицій: культура/природа; матеріальне/духовне; радість/горе; здоров'я/хвороба; краса/потворність, який передбачає розроблення методики лінгвокогнітивного та лінгвокультурологічного аналізу художніх та медіатекстів на основі виділення вербально-невербальних маркерів ціннісних домінант, що сприяють формуванню постмодерної картини світу в аспекті постання нових культурних цінностей і антицінностей.

Об'єктом такого дослідження можуть виступити медіатексти корпусів мов (української, російської, англійської, французької, німецької, іспанської тощо), а також відповідні художні дискурси XXI століття, розглядувані у контексті представлення змін аксіологічних домінант постмодерного світу. Предметом виступить дослідження особливостей процесу трансформації базових соціокультурних цінностей у постмодерному соціумі, відображені у мовних інноваціях і змінах, у розгортанні та реалізації дискурсивних практик на матеріалі медіа- та художніх текстів української, російської, англійської, французької, німецької мов тощо.

Для реалізації заявленої мети вже створено необхідне підгрунтя. Так, напрацьовано методологію дослідження, а саме: 1) розроблені методи зіставних досліджень мовно-концептуальних систем і аксіологічних домінант у різних лінгвокультурах (І. О. Голубовська, О. Левко), у тому числі в діахронічному вимірі на прикладі окремих концептів (I. О. Голубовська, О. В. Левко, Л. В. Клименко, Г. А. Черненко);

Дослідницький проект [Исследовательский проект] () Голубовська І. О., Дарчук Н. П., Черненко А. А. [Голубовская И. А., Дарчук Н. П., Черненко А. А.], igolubovska777@gmail.com,nataliadarchuk@gmail.com,hanna.chernenko@gmail.com Мова і дискурсивні практики світового медіапростору у контексті змін аксіологічних домінант [Язык и дискурсивные практики мирового медиапространства в контексте изменений аксиологических доминант] (Українською / На укр. яз) 
2) опрацьовано методику опису процесів формування ціннісних концептів (Г. А.Черненко); 3) осмислено фразеологізм як маркер активних соціальних процесів, вербалізованих у масовій свідомості (Д. Ю. Сизонов); 4) досліджено трансформації у мові медіа-, зокрема Інтернет-простору, в умовах інформаційної війни та аксіологічних зрушень, викликаних нею, на матеріалі читацьких коментарів та експертного дискурсу (Л. В. Клименко); 5) розроблена методика викриття персуазивного впливу (метастратегії плюс та мінус) у рамках політичного дискурсу (I. О. Голубовська, Д. Д. Харитонова); 6) доступні он-лайн корпуси європейських мов, які можуть стати надійним інструментом вивчення названих явищ (зокрема Корпус української мови, у рамках якого професор Н. П. Дарчук планує розробити універсальні принципи семантичної параметризації аксіологічно заангажованої лексики). Всі ці напрацювання, будучи інтегрованими в єдиний проект, забезпечать цілісне бачення тенденцій розвитку сучасної мови, представлені у медіапросторі різних мов, який на початку XXI ст. набув принципово нових форм і охоплює практично всі сфери людського буття, відображаючи його аксіологічні виміри і водночас впливаючи на них.

Виконання поставлених завдань передбачає продовження та поглиблення напрацювань світової та української науки в галузі вивчення взаємозв'язку між мовно-когнітивною та аксіосферою на матеріалі медіата художніх текстів. Це, зокрема, доробок представників медіалінгвістики (Д. Перрін, Л. О. Кудрявцева, Л. І. Шевченко та ін.), критичного дискурсаналізу (Р. Водак, Т. ван Дейк, Н. Ферклоу та ін.), у якому продемонстровано можливості філологічного аналізу в площині експлікації ціннісних настанов, що транслюються за допомогою мови та виформовуються iï засобами. Власне мовні аксіологічні структури, які неминуче при цьому оприявнюються, детально було описано в працях Г. фон Врігта, О. А. Івіна, О. М. Вольф, В. М. Телії, Н. Д. Арутюнової, Т. А. Космеди. Здобутки когнітологів (М. М. Болдирєв П. Вайт, Р. Джекендофф, С. А. Жаботинска, Дж. Лакофф, Р. Ленекер, Дж. Мартін тощо) надають можливість перейти на інший - прагматично та соціокультурно заангажований рівень розуміння аксіологічних змін, які презентуються медіатекстами та текстами художньої літератури. 
Дискурсивні вияви цінностей як феноменів лінгвокультури вивчали T. Вельхофф, Ж. Житвогнан, С. Жан-Франсуаз, В. І. Карасик. Спроби каталогізувати цінності робилися від часів античності (Аристотель) до сьогодення (Г. Ласуел, А. Маслоу, Ш. Шварц та ін.). Мовознавці доповнили ці напрацювання культурно маркованими тезаурусами (Л. К. Байрамова， С. Бартмінські, О.І.Бессонова, В. І. Кононенко, Я. Пузиніна та ін.). Однак очевидною $є$ прогалина в дослідженнях динамічних процесів в аксіосфері, реалізованих тими чи тими мовнокогнітивними структурами. $€$ нагальна потреба у створенні дослідницької рамки вивчення тих явищ мови та мовлення, що заангажовані ціннісно: мовне конструювання ідентичності, відстеження факторів іiі змінності (О. Гнатюк, В. М. Кулик, М. Рейзігл, М. Рябчук, Ф. Рібейро та ін.), мова ворожнечі, аксіологічних конфліктів і ширше - консцієнтальних, інформаційних воєн $\quad$ (В. П. Горбулін, Л. Ф. Компанцева, О. С. Снитко, Н. В. Слухай, Г. М. Яворська). Хоча в деяких працях зроблено спроби описати закономірності семантичних змін на рівні аксіології значення (Т. М. Антонченко, С.В. Зубарєв, О.В.Орлова, О.О.Ткаченко та ін.), проте все ще не вистачає дослідницької моделі, яка б надала можливість аналітичного охоплення всіх трансформацій, що пов'язані 3 перетвореннями в системі суспільних аксіологічних домінант та їх рефлексами у вигляді тих чи тих особливостей розвитку мови та мовлення. Саме на цих проблемах, які досі лишаються недостатньо вивченими, планується зосередити дослідницьку увагу, залучивши, чи не вперше, для ïх вирішення досягнення світової корпусної лінгвістики.

Постіндустріальна ера інформаційного суспільства зумовила карколомні зміни фактично на всіх ділянках суспільного життя, спричинила появу нової ієрархії цінностей, індукувала формування принципово нової картини світу найновішого часу. Мова як найчутливіший індикатор суспільно-політичних змін закарбовує у своїх лексико-фразеологічних формах і дискурсивних реалізаціях трансформацію старих і появу нових соціокультурних цінностей, які нерозривно пов'язані із виникненням нових смислів людського буття. Сучасні медійні тексти та сучасний художній дискурс, маючи потужний потенціал впливу на людську особистість, фіксують цю нову систему

Дослідницький проект [Исследовательский проект] (ㄱ Голубовська І. О., Дарчук Н. П., Черненко А. А. [Голубовская И. А., Дарчук Н. П., Черненко А. А.], igolubovska777@gmail.com,nataliadarchuk@gmail.com,hanna.chernenko@gmail.com Мова і дискурсивні практики світового медіапростору у контексті змін аксіологічних домінант [Язык и дискурсивные практики мирового медиапространства в контексте изменений аксиологических доминант] (Українською / На укр. яз) 
ціннісних смислів. Причому, якщо медіадискурс їі часто-густо нав'язує за допомогою маніпулятивних стратегій і тактик, - у художньому дискурсі відбувається iї рефлексія. Таким чином, виникає нагальна потреба в дослідженні еволюції соціокультурних цінностей, що виступають орієнтирами індивідуального та суспільного життя людини, які можуть бути відстежені на мовно-дискурсивному матеріалі за допомогою віднайдення певних вербально-авербальних маркерів трансформацій і змін у ментальності того чи того етносу.

Робоча гіпотеза такого масштабного проекту полягатиме в тому, що дослідження мовних та дискурсивних рефлексів змін у ціннісних настановах сучасного нам суспільства, зроблене із залученням корпусних даних на матеріалі мов «середньоєвропейського стандарту», виявить основні риси нової концептуальної картини світу сучасності на підставі окреслення спільної для багатьох етносів (принаймні європейських) системи цінностей та антицінностей.

Мету проекту можна сформулювати як створення алгоритму аналізу процесу змін аксіологічних орієнтацій суспільства, який буде здійснений на матеріалі художніх та медіатекстів із залученням корпусного підходу до опрацювання мовно-мовленнєвих даних. Поставлена мета імплікує розв'язання таких завдань:

1) Проаналізувати і схарактеризувати основні наукові підходи до вивчення мови ЗМІ та постмодерного літературного тексту в міждисциплінарному аспекті на перетині ідей, що сформувалися у сучасній лінгвокультурології, лінгвокогнітології, медіалінгвістиці, політичній лінгвістиці, філософії, герменевтиці, літературознавстві.

2) Вивчити соціальні, політичні, економічні, психологічні, лінгвістичні та інші фактори впливу на сучасну людину в аспекті змін аксіологічних констант в іiі сприйнятті дійсності та виформовування нової постмодерної картини світу.

3) Визначити універсальні, а також національно-специфічні для окремих культур аксіологічні домінанти на матеріалі сучасних офіційних (газети, журнали, комерційні сайти) та неофіційних (інтернет-блоги, чати, дискусії, форуми) інтернет-ресурсів із 
урахуванням фундаментальних змін в аксіосфері суспільства, які відбулися протягом останніх 10-15-ти років; розробити їх типологію.

4) Опрацювати інтегрований підхід до аналізу мови ЗМІ та постмодерного літературного тексту, який передбачав би виділення вербально-невербальних маркерів ціннісних домінант на основі застосування лінгвоінформаційних технологій ментально-мовної кластеризації текстів корпусів мов та їх лінгвістичної експертизи.

Актуальність такого роду дослідження зумовлена повною відсутністю системних досліджень у заявленій площині як на вітчизняних теренах, так і за кордоном, адже наразі не існує розвідок, у рамках яких була б зроблена спроба дослідити зміни в аксіосфері сучасного суспільства на матеріалі багатьох європейських мов із залученням корпусного підходу до опрацювання мовно-мовленнєвих даних і виділення при цьому як глобальних, так i національно-специфічних цінностей, притаманних окремим лінгвокультурам.

В основу цього дослідження буде покладено антропоцентричний підхід як скерований на людину та прагматику ії життя, а також комплекс неолінгвістичних підходів до тлумачення лексико-фразеологічних та лексико-граматичних інновацій у медіа, які розглядатимуться під лінгвокогнітивним, лінгвокультурологічним, лінгвопрагматичним, дискурсивним, сугестивним кутами зору. Базою для здійснення всіх вище зазначених підходів виступатимуть лінгвоінформаційні технології корпусів опрацьовуваних мов. Щодо матеріалів КУМ (Корпусу української мови), на його основі буде здійснено ментально-мовну кластеризацію текстів Корпусу, лінгвістичну параметризацію як підгрунтя для експертизи будь-якого тексту, на основі чого будуть інтерпретовані результати лінгвістичної експертизи. Такого роду підхід ще ніколи не опробовувався 3 метою дослідження мовних рефлексів аксіологічних зсувів у свідомості різних етносів. Кінцевою метою проекту буде створення цілісного дослідницького діахронно заангажованого фрейму у царині опрацювання мовно-мовленнєвих проекцій динаміки змін аксіологічних констант, досліджуваних на матеріалах корпусів мов.

Дослідницький проект [Исследовательский проект]

() Голубовська І. О., Дарчук Н. П., Черненко А. А. [Голубовская И. А., Дарчук Н. П., Черненко А. А.], igolubovska777@gmail.com,nataliadarchuk@gmail.com, hanna.chernenko@gmail.com Мова і дискурсивні практики світового медіапростору у контексті змін аксіологічних домінант [Язык и дискурсивные практики мирового медиапространства в контексте изменений аксиологических доминант] (Українською / На укр. яз) 
Для здійснення проекту будуть застосовуватися описовий, порівняльний, зіставно-типологічний, таксономічний методи; методи аналізу, синтезу, індукції, дедукції; методи структурно-семантичного аналізу слова: компонентний та контекстуальний аналіз, трансформаційний метод, функціонально-стилістичний метод, метод безпосередніх складників та дерев залежностей, кількісно-якісного аналізу, статистичного аналізу; методи, що постали у новітній час: метод дискурсаналізу та метод контент-аналізу, прототипічний аналіз, метод концептуального аналізу, фреймового / гештальт-аналізу, конверсаційного, прагматичного та текстологічного аналізу, лінгвокультурологічної інтерпретації, внутрішньої інтроспекції; комплекс медіалінгвістичних методів - медіапланування, медіамоніторингу, медіафреймінгу та ін.

У рамках проекту планується: 1) розробити методику лінгводеконструкції вербалізованих аксіологічних структур, що надасть можливість оприявнювати приховані ціннісні настанови мовця та його наміри впливати на аксіологічні уподобання адресата, розпізнавати способи такого впливу, реалізовані на різних рівнях мовної системи і тексту; 2) віднайти закономірності впливу мас-медійних та художніх текстів на процес трансформації аксіологічних домінант світової та української громади; 3) відстежити новації у розвитку національних систем мов (поява нових лексичних та фразеологічних одиниць неолексем і неофразем); 4) установити напрямки зміни мовної норми під впливом узуально-оказіональних використань; 5) розробити програмне забезпечення для автоматичної лінгвістичної експертизи текстів, яка надаватиме досліднику повну інформацію про текст, висвітлюючи його аспекти: функціональний (оцінка за вживаністю); синтагматичний (сполучуваність - оцінюється за якісними та кількісними ознаками; Lграми); епідигматичний (оцінювання за кількістю значень словникових одиниць); парадигматичний (входження словникових одиниць до різних лексичних парадигм); хронологічний (накопичена частота вживаності лексем у певний часовий період).

Очікувані результати спиратимуться передусім на спостереження за семіотичною реальністю мовного узусу, представленого у світовому та українському медіа- та художньому просторі, результати чого будуть 
піддані багатоаспектному мовознавчому аналізу із залученням статистичних даних електронних корпусів мов (англійської, німецької, української та інших). Першочерговим завданням у цій царині можна вважати розроблення способів фіксації культурно та ціннісно маркованих мовно-мовленнєвих одиниць різного рівня абстракції.

Наразі не існує досліджень, у рамках яких було б зроблено спробу дослідити зміну аксіосфери сучасного суспільства на матеріалі декількох мов із залученням корпусного підходу до опрацювання мовномовленнєвих даних із подальшим виділенням як універсальних, так i національно-специфічних цінностей, притаманних окремим лінгвокультурам. I хоча вплив суспільства на розвиток мови в лінгвістиці висвітлюється 3 початку 2000-х рр. [Блакар 1987; Кудрявцева, Дядечко, 2005], це робилося переважно соціологами, які досліджували ціннісні аспекти такого впливу, звертаючись до кількісних методів, передусім контент-аналізу. Філологи ж $з$ пропозицією якісного аналізу семантики мовних та мовленнєвих одиниць все ще залишаються на маргінесах. Так, запропонований О. О. Тараненком [Тараненко 2012-2014] аналіз формування аксіологічних пріоритетів українського суспільства не охоплює тих процесів, що відбуваються за межами українського інформаційного простору; окрім того, автор зосереджується переважно на словотвірних аспектах мовного буття, - водночас у пропонованому дослідженні передбачено охопити різні рівні мовного аналізу, починаючи від морфолого-лексичного аж до рівня семантики тексту та метадискурсу. Праця Р. Джекендоффа [Jackendoff 2001] розкриває структуру ціннісного концепту, але не дає уявлення про динаміку його формування й трансформації, зокрема у взаємозв'язку з іншими мовними процесами, що відбуваються у медіапросторі. Пропоноване дослідження якраз зосереджено на з'ясуванні специфіки моделей аксіологічних трансформацій, які відбуваються у просторі сучасних медіа. Окрім того, давно вже виникла нагальна потреба опробовування методу критичного дискурс-аналізу у царині мовознавства [Wodak, Meyer 2009].

Новизна методики автоматизованої лінгвістичної експертизи тексту, яка покликана забезпечити автоматичну обробку частини даних та їхній статистичний аналіз, зумовлена тим, що сучасні корпуси мов часто-густо

Дослідницький проект [Исследовательский проект]

(С) Голубовська І. О., Дарчук Н. П., Черненко А. А. [Голубовская И. А., Дарчук Н. П., Черненко А. А.], igolubovska777@gmail.com,nataliadarchuk@gmail.com,hanna.chernenko@gmail.com

Мова і дискурсивні практики світового медіапростору у контексті змін аксіологічних домінант [Язык и дискурсивные практики мирового медиапространства в контексте изменений аксиологических доминант] (Українською / На укр. яз) 
не дають можливості отримати інформацію про граматичні та семантичні особливості аналізованого тексту (див. альтернативні корпуси української мови он-лайн: korpus.org.ua/search/; Проект групи Lang-Ukr. URL: http://lang.org.ua/uk/; General Regionally annotated Corpus of Ukraine. URL: http://uacorpus.org/; Корпуси текстів української мови ДонНУ. URL: corpora.donnu.edu.uа та ін.).

Очікувані результати можуть суттєво вплинути на розширення можливостей саморефлексії людини у контексті оприявнення аксіологічних настанов, які мовці умисно чи мимохіть транслюють у своїй повсякденній комунікації (багато 3 них формують саме медіа- та художні тексти). Це вкрай важливо в умовах інформаційної, консцієнтальної війни, коли існує потреба у підвищенні рівня критичного сприйняття масмедійних текстів, які дуже часто виступають знаряддям політичної пропаганди. Так само нагальною $є$ потреба розуміння, які саме засоби використовують авторитетні мовці для формування певної ціннісної ієрархії суспільства; діагностування аксіологічних змін на рівні функціонування медіадискурсу в період активізації глобалізаційних процесів, коли стикаються та перетинаються різні системи цінностей. Особливої актуальності зміна ціннісної шкали набуває у наш час, коли відбувається бурхливий розвиток української нації як особливої спільноти зі своєю мовно-культурною ідентичністю і своєю системою традиційних цінностей. Примат ідеального на матеріальним, який зумовлює наукову й концептуальну картини світу сучасності, фактично ставить економічний успіх країни в залежність від тих аксіологічних домінант гуманітарної сфери, які вже довели свою ефективність на прикладі розвинених європейських країн та США.

Результати планованого дослідження нададуть можливість запропонувати цілісне бачення мовних та дискурсивних процесів, що відбуваються в сучасному світовому та українському медіапросторі під впливом аксіологічних змін. Вироблення необхідних методів та методик дослідження цих процесів, зокрема автоматизованої експертизи текстів, аксіологічної лінгводеконструкції, діахронного моделювання аксіологічних мовних змін тощо суттєво збагатить методологометодичний апарат сучасного мовознавства та гуманітарних наук у 
цілому, що є конче необхідним для дослідження цілого комплексу актуальних на сьогодні проблем конструювання ідентичності, міжкультурної комунікації, 3'ясування специфіки мови ворожнечі, осмислення тоталітарного та колоніального минулого країн пострадянського простору, і не тільки.

Висновки щодо особливостей відображення в мові аксіологічних домінант, які виформовують світоспоглядання сучасної людини, їх впливу на становлення нового формату громадянського суспільства, стануть логічним продовженням сучасних напрацювань у царині мовної семантики, лінгвоконцептології, прагмалінгвістики, корпусної лінгвістики, піднімаючи філологічні напрацювання сьогодення на якісно новий рівень усвідомлення та узагальнення у контексті потреб саморефлексії людства у цілому.

\section{Література:}

1. Арутюнова, Н. Д. Язык и мир человека (Москва, Языки русской культуры, 1999), 896.

2. Бессонова, О. Л. «Оцінний тезаурус англійської мови: когнітивний i гендерний аспекти.» Автореф. дис. д-ра філол. наук, Київ, 2003.

3. Блакар, Р. М. «Язык как инструмент социальной власти.» Язык $u$ моделирование сочиального взаимодействия, сост. В. М. Сергеева и П. Б. Паршина; общ. ред. В. В. Петрова (Москва, Прогресс, 1987): 88-125.

4. Водак, Р. «Взаимосвязь «дискурс - общество»: когнитивный подход к критическому дискурс-анализу.» Современная политическая лингвистика, Э. В. Будаев, А. П. Чудинов (Екатеринбург, 2006): 123-136.

5. Водак, Р. «Критическая лингвистика и критический анализ дискурса.» Политическая лингвистика 4 (38) (2011): 286-291.

6. Вригт, Г. Х. фон. Логико-философские исследования: избранные труды, пер. с англ. Е. И. Тарусина, А. С. Карпенко и др.; общ. ред. Г. В. Рузавина, В. А. Смирнова (Москва, Прогресс, 1986), 600.

7. Вольф, Е. М. «Оценочное значение и соотношение признаков «хорошо» / «плохо».» Вопросы языкознания 5 (1986): 98-106.

8. Голубовська, І. О. «Мова соціальних мереж як новітній лінгвістичний феномен.» Мовні і концептуальні картини світу 55 (2) (2015): 49-56.

9. Голубовська, I. О., Клименко, Л. В., Левко, О. В., Гудзенко, О. П., Александрова, Г. А., Черненко, А. А. Концепти і конщептосфери: динамічні виміри:

Дослідницький проект [Исследовательский проект]

() Голубовська І. О., Дарчук Н. П., Черненко А. А. [Голубовская И. А., Дарчук Н. П., Черненко А. А.], igolubovska777@gmail.com,nataliadarchuk@gmail.com,hanna.chernenko@gmail.com

Мова і дискурсивні практики світового медіапростору у контексті змін аксіологічних домінант [Язык и дискурсивные практики мирового медиапространства в контексте изменений аксиологических доминант] (Українською / На укр. яз) 
колективна монографія, під ред. І. О. Голубовської, Л. В. Клименко (Київ, Логос, 2017), 178.

10. Голубовська, I. O, Орлова, Т. В. Політичний дискурс як інструмент маніпулювання свідомістю електорату (на матеріалі інавгураційної промови Дональда Трампа 20 січня 2017 р.).» Studia Linguistica 11 (2017): 9-29.

11. Голубовська, I. О., Черненко, Г. А. «Фреймове моделювання концепту ДОБРОЧЕСНІСТЬ: зіставний аспект.» Мовознавство 1 (2017): 3-12.

12. Дарчук, Н. П. «Корпус текстів Тараса Шевченка як джерело для мовознавчих студій.» Science and Education: A New Dimension. Philology 32, Issue 122 (Budapest, 2017): 33-38.

13. Дарчук, Н. П. «Компьютерная грамматика украинского языка АГАТ и перспективы ее использования.» Актуальные проблемы современной прикладной лингвистики 37 (Минск, 2017): 37-43.

14. Дарчук, Н. П., Алексієнко, Л. А. «Автоматичне конструювання частотного словника сполучуваності української мови.» Сучасна україністика: Проблеми мови, літератури і культури. Оломоуцький симпозіум украӥністів (Оломоуць, 2016): 33-38.

15. Жаботинская, С. А. «Язык как оружие в войне мировоззрений. Майдан Антимайдан: словарь-тезаурус лексических инноваций : Украина, декабрь 2013 декабрь 2014.» Интернет-издание (Киев, Укр. асоц. когнітивної лінгвістики і поетики, 2015), доступ http://uaclip.at.ua/zhabotinskaja-jazyk_kak_oruzhie.pdf (дата обращения: 30.01.2018).

16. Ивин, А. А. Аксиология (Москва, Высш. шк., 2006), 390.

17. Клименко, Л. В. «Семантичний простір фланерства у французькій лінгвокультурі.» Science and Education a New Dimension. Philology 31 (V), Issue 118 (Budapest, 2017): 33-36.

18. Кудрявцева, Л. О., Дядечко Л. П., Дорофєєва О. М., $\quad$ Черненко Г. А., Філатенко І. О. «Сучасні аспекти дослідження мас-медійного дискурсу: експресія вплив - маніпуляція.» Мовознавство 1 (2005): 58-66.

19. Levko, O. «Somatic means of emotion verbalization in Ancient Greek and Ukrainian linguocultures.» Science and Education: A New Dimension. Philology 26 (IV), Issue 106 (Budapest, 2016): 30-33.

20. Левко, О. «Діахронні виміри вербалізації концептів ПРАВЕДНІСТЬ і $\triangle \mathrm{IKAIO \Sigma YNH} \mathrm{в} \mathrm{українській} \mathrm{мові} \mathrm{та} \mathrm{грецькій} \mathrm{мові} \mathrm{Нового} \mathrm{Завіту:} \mathrm{точки} \mathrm{перетину.»}$ Studia linguistica 9 (2016): 54-63.

21. Лингвистика и аксиология. Этносемиометрия ценностных смыслов: коллективная монография, Е. Ф. Серебренникова, Н. П. Антипьев, Л. Г. Викулова и др. (Москва, Тезаурус, 2011), 352.

22. Сизонов, Д. Ю. «Психолінгвістичні основи медіаграмотності: до проблеми інтерпретації медіатекстів.» Science and education 7 (2017): 82-88.

23. Тараненко, О.О. «Українська мова і сучасна мовна ситуація в Україні.» Мовознавство 4 (2001): 3-19.

Research Project [Doslidnyc'kyj proekt]

(C) Golubovska I., Darchuk N., Chernenko H. [Golubovs'ka I. O., Darchuk N. P., Chernenko A. A.], igolubovska777@gmail.com,nataliadarchuk@gmail.com, hanna.chernenko@gmail.com

Language and Discourse Practices of World Media in the Context of Axiological Dominants' Change [Mova i dyskursyvni praktyky svitovogo mediaprostoru u konteksti zmin aksiologichnyh dominant] (in Ukrainian) 
24. Тараненко, О.О. «Формування нової системи соціальних цінностей i пріоритетів українського суспільства (на матеріалі української мови кінця $\mathrm{XX}$ - початку XXI ст.).» Мовознавство (2012), № 3: 3-31; № 5: 13-40; № 6: 3-22 ; (2013), № 6: 3-26 ; (2014), № 1: 3-31; № 3: 3-33; № 5: 14-34.

25. Харитонова, Д. Д. «Реалізація дихотомії «свій $\leftrightarrow$ чужий» у політичному дискурсі (на матеріалі виступу в суді Ю. В. Тимошенко).» Науковий вісник Міжнародного гуманітарного університету, Серія: Філологія 27, т 1 (Одеса, 2017): 154-157.

26. Шевченко, Л. І. «Медіалінгвістика в сучасній Україні: аналіз ситуації.» Актуальні проблеми украӥнської лінгвістики:теорія і практика 26 (2013): 3-12.

27. Черненко, А. А. Мовленнєвий вплив на ціннісні системи: діапазон імовірностей (Київ, Видавничий дім «Дмитра Бураго», 2018), 404.

28. Яворська, Г. М. «До проблеми формування європейської ідентичності в Україні.» Наукові записки Інституту політичних $і$ етнографічних досліджень ім. I. Ф. Kураса 42 (2008): 269-277.

29. Bartmiński, J. «Projekt i założenia ogólne słownika aksjologicznego.», [w:] Język a Kultura, t. 2, red. Jerzy Bartmiński, Jadwiga Puzynina (Wrocław, 1989): 293-312.

30. Golubovska, I. «Lingual Concept: Epistemic Approaches in Modern Ukrainian Linguistics.» Науковий вісник Міжнародного гуманітарного університету, Серія: Філологія 27, т. 1 (Одеса, 2017): 128-132.

31. Fairclough, N. Discourse and SocialChange (Cambridge, PolityPress, 1992), 259.

32. Fairclough, I. \& Fairclough, N. Political Discourse Analysis. A Method for Advanced Students (London, Routledge, 2012).

33. Jackendoff, R. «The peculiar logics of Value.» Journal of Cognition and Culture 34 (2001): 375-407.

34. Wodak, R., Meyer, M. Critical discourse analysis: history, agenda, theory, and methodology. Methods for Critical Discourse Analysis, ed. by Wodak, Ruth (London, Sage, 2009): 1-33.

\section{References}

1. Arutjunova, N. D. Jazyk i mir cheloveka (Moskva, Jazyki russkoj kul'tury, 1999), 896.

2. Bjessonova, O. L. «Ocinnyj tezaurus anglijs'koi' movy: kognityvnyj i gendernyj aspekty.» Avtoref. dys. d-ra filol. nauk, Kyi'v, 2003.

3. Blakar, R. M. «Jazyk kak instrument social'noj vlasti.» Jazyk i modelirovanie social'nogo vzaimodejstvija, sost. V. M. Sergeeva i P. B. Parshina; obshh. red. V. V. Petrova (Moskva, Progress, 1987): 88-125.

Дослідницький проект [Исследовательский проект]

(С Голубовська І. О., Дарчук Н. П., Черненко А. А. [Голубовская И. А., Дарчук Н. П., Черненко А. А.], igolubovska777@gmail.com, nataliadarchuk@gmail.com, hanna.chernenko@gmail.com

Мова і дискурсивні практики світового медіапростору у контексті змін аксіологічних домінант [Язык и дискурсивные практики мирового медиапространства в контексте изменений аксиологических доминант] (Українською / На укр. яз) 
4. Vodak, R. «Vzaimosvjaz' «diskurs - obshhestvo»: kognitivnyj podhod $\mathrm{k}$ kriticheskomu diskurs-analizu.» Sovremennaja politicheskaja lingvistika, Je. V. Budaev, A. P. Chudinov (Ekaterinburg, 2006): 123-136.

5. Vodak, R. «Kriticheskaja lingvistika i kriticheskij analiz diskursa.» Politicheskaja lingvistika 4 (38) (2011): 286-291.

6. Vrigt, G. H. fon. Logiko-filosofskie issledovanija: izbrannye trudy, per. s angl. E. I. Tarusina, A. S. Karpenko i dr.; obshh. red. G. V. Ruzavina, V. A. Smirnova (Moskva, Progress, 1986), 600.

7. Vol'f, E. M. «Ocenochnoe znachenie i sootnoshenie priznakov «horosho» / «ploho».» Voprosy jazykoznanija 5 (1986): 98-106.

8. Golubovs'ka, I. O. «Mova social'nyh merezh jak novitnij lingvistychnyj fenomen.» Movni i konceptual'ni kartyny svitu 55 (2) (2015): 49-56.

9. Golubovs'ka, I. O., $\quad$ Klymenko, L. V., $\quad$ Levko, O. V., $\quad$ Gudzenko, O. P., Aleksandrova, G. A., Chernenko, A. A. Koncepty i konceptosfery: dynamichni vymiry: kolektyvna monografija, pid red. I. O. Golubovs'koi', L. V. Klymenko (Kyi'v, Logos, 2017), 178.

10. Golubovs'ka, I. O, Orlova, T. V. P»olitychnyj dyskurs jak instrument manipuljuvannja svidomistju elektoratu (na materiali inavguracijnoi' promovy Donal'da Trampa 20 sichnja 2017 r.).» Studia Linguistica 11 (2017): 9-29.

11. Golubovs'ka, I. O., Chernenko, G. A. «Frejmove modeljuvannja konceptu DOBROChESNIST": zistavnyj aspekt.» Movoznavstvo 1 (2017): 3-12.

12. Darchuk, N. P. «Korpus tekstiv Tarasa Shevchenka jak dzherelo dlja movoznavchyh studij.» Science and Education: A New Dimension. Philology 32, Issue 122 (Budapest, 2017): 33-38.

13. Darchuk, N. P. «Komp'juternaja grammatika ukrainskogo jazyka AGAT i perspektivy ee ispol'zovanija.» Aktual'nye problemy sovremennoj prikladnoj lingvistiki 37 (Minsk, 2017): 37-43.

14. Darchuk, N. P., Aleksijenko, L. A. «Avtomatychne konstrujuvannja chastotnogo slovnyka spoluchuvanosti ukrai'ns'koi' movy.» Suchasna ukrai'nistyka: Problemy movy, literatury i kul'tury. Olomouc'kyj sympozium ukrai'nistiv (Olomouc', 2016): 33-38.

15. Zhabotinskaja, S. A. «Jazyk kak oruzhie v vojne mirovozzrenij. Majdan Antimajdan : slovar'-tezaurus leksicheskih innovacij : Ukraina, dekabr' 2013 - dekabr' 2014.» Internet-izdanie (Kiev, Ukr. asoc. kognitivnoï lingvistiki i poetiki, 2015), dostup http://uaclip.at.ua/zhabotinskaja-jazyk_kak_oruzhie.pdf (data obrashhenija: 30.01.2018).

16. Ivin, A. A. Aksiologija (Moskva, Vyssh. shk., 2006), 390.

17. Klymenko, L. V. «Semantychnyj prostir flanerstva u francuz'kij lingvokul'turi.» Science and Education a New Dimension. Philology 31 (V), Issue 118 (Budapest, 2017): 33-36.

18. Kudrjavceva, L. O., $\quad$ Djadechko, L. P., $\quad$ Dorofjejeva, O. M., Chernenko, G. A., Filatenko I. O. «Suchasni aspekty doslidzhennja mas-medijnogo dyskursu: ekspresija vplyv - manipuljacija.» Movoznavstvo 1 (2005): 58-66.

Research Project [Doslidnyc'kyj proekt]

(C) Golubovska I., Darchuk N., Chernenko H. [Golubovs'ka I. O., Darchuk N. P., Chernenko A. A.], igolubovska777@gmail.com,nataliadarchuk@gmail.com,hanna.chernenko@gmail.com

Language and Discourse Practices of World Media in the Context of Axiological Dominants' Change [Mova i dyskursyvni praktyky svitovogo mediaprostoru u konteksti zmin aksiologichnyh dominant] (in Ukrainian) 
19. Levko, O. «Somatic means of emotion verbalization in Ancient Greek and Ukrainian linguocultures.» Science and Education: A New Dimension. Philology 26 (IV), Issue 106 (Budapest, 2016): 30-33.

20. Levko, O. «Diahronni vymiry verbalizacii' konceptiv PRAVEDNIST" i $\triangle \mathrm{IKAIO} \Sigma \mathrm{YNH}$ v ukrai'ns'kij movi ta grec'kij movi Novogo Zavitu: tochky peretynu.» Studia linguistica 9 (2016): 54-63.

21. Lingvistika i aksiologija. Jetnosemiometrija cennostnyh smyslov: kollektivnaja monografija, E. F. Serebrennikova, N. P. Antip'ev, L. G. Vikulova i dr. (Moskva, Tezaurus, 2011), 352.

22. Syzonov, D. Ju. «Psyholingvistychni osnovy mediagramotnosti: do problemy interpretacii' mediatekstiv.» Science and education 7 (2017): 82-88.

23. Taranenko, O. O. «Ukrai'ns'ka mova i suchasna movna sytuacija v Ukrai'ni.» Movoznavstvo 4 (2001): 3-19.

24. Taranenko, O. O. «Formuvannja novoi' systemy social'nyh cinnostej i priorytetiv ukrai'ns'kogo suspil'stva (na materiali ukrai'ns'koi' movy kincja $\mathrm{HH}$ - pochatku HHI st.).» Movoznavstvo (2012), № 3: 3-31; № 5: 13-40; № 6: 3-22; (2013), № 6: 3-26; (2014), № 1: 3-31; № 3: 3-33; № 5: 14-34.

25. Harytonova, D. D. «Realizacija dyhotomii' «svij ↔ chuzhyj» u politychnomu dyskursi (na materiali vystupu v sudi Ju. V. Tymoshenko).» Naukovyj visnyk Mizhnarodnogo gumanitarnogo universytetu, Serija: Filologija 27, t 1 (Odesa, 2017): 154-157.

26. Shevchenko, L. I. «Medialingvistyka v suchasnij Ukrai'ni: analiz sytuacii'.» Aktual'ni problemy ukrai'ns'koi' lingvistyky:teorija i praktyka 26 (2013): 3-12.

27. Chernenko, A. A. Movlennjevyj vplyv na cinnisni systemy: diapazon imovirnostej (Kyi'v, Vydavnychyj dim «Dmytra Burago», 2018), 404.

28. Javors'ka, G. M. «Do problemy formuvannja jevropejs'koi' identychnosti v Ukrai'ni.» Naukovi zapysky Instytutu politychnyh i etnografichnyh doslidzhen' im. I. F. Kurasa 42 (2008): 269-277.

29. Bartmiński, J. «Projekt i założenia ogólne słownika aksjologicznego.», [w:] Język a Kultura, t. 2, red. Jerzy Bartmiński, Jadwiga Puzynina (Wrocław, 1989): 293-312.

30. Golubovska, I. «Lingual Concept: Epistemic Approaches in Modern Ukrainian Linguistics.» Науковий вісник Міжнародного гуманітарного університету, Серія: Філологія 27, т. 1 (Одеса, 2017): 128-132.

31. Fairclough, N. Discourse and SocialChange (Cambridge, PolityPress, 1992), 259.

32. Fairclough, I. \& Fairclough, N. Political Discourse Analysis. A Method for Advanced Students (London, Routledge, 2012).

33. Jackendoff, R. «The peculiar logics of Value.» Journal of Cognition and Culture 3-4 (2001): 375-407.

34. Wodak, R., Meyer, M. Critical discourse analysis: history, agenda, theory, and methodology. Methods for Critical Discourse Analysis, ed. by Wodak, Ruth (London, Sage, 2009): 1-33.

Дослідницький проект [Исследовательский проект]

(С Голубовська І. О., Дарчук Н. П., Черненко А. А. [Голубовская И. А., Дарчук Н. П., Черненко А. А.], igolubovska777@gmail.com, nataliadarchuk@gmail.com, hanna.chernenko@gmail.com

Мова і дискурсивні практики світового медіапростору у контексті змін аксіологічних домінант [Язык и дискурсивные практики мирового медиапространства в контексте изменений аксиологических доминант] (Українською / На укр. яз) 


\title{
How Greek Language is Studied and Researched in Ukraine (on the occasion of International Greek Language Day 9.02.19.)
}

\author{
Golubovska Iryna, igolubovska777@gmail.com \\ Doctor of Science, Full prof. \\ Taras Shevchenko National University of Kyiv, \\ Institute of Philology
}

Study of the Greek language has a long tradition in Ukraine. It goes back to KyevanRus'being determinedby the close contacts of Ukrainians and Greeks, by the necessity in economical and spiritual communication. In the XVI-th XVII-th centuries the Greek language was taught at the so called fraternal schools. Within the activities of Lviv fraternal school Arseniy Elassonskiy, who trained the pupils of this school, wrote the grammar book of the Greek language. At KyivMohyla Academyfounded by Petro Mogyla in 1632 there was a 12-year program of the Greek language teaching. In the XVIII-th century at collegiums of Odessa, Poltava, Kharkiv, Kherson, Chernivtsithe Old Greek language was taught. In the XIX-th century at the new-born universities in such cities as Odessa, Kharkiv, Lviv the programs of historical-philological departments presupposed the study of the Old Greek language, history, philosophy, culture. Kyiv University of Saint Volodymyr founded in 1834 from the day of its foundation had the chair of the Greek language. Such prominent specialists in the field of classical philology as I. Neikirkh, M. Skvortsov, F. Mischenko, A. Sonni, F. Knauer, J. Kulakovskij, I. Tsvetajev and others delivered the courses in Greek culture, Old Greek language; made translations from the Old Greek into Russian. M. Skvortsov had translated Plato's dialogues, F. Mischenko had made translations of the pieces of Fukidid, Polybius, Herodot. Later on, in a century, "Histories" by Herodot were translated into Russian by the prominent Ukrainian scholar A. Biletskiy. In Kharkiv university academician of Russian and Ukrainian Academies V. Buzeskul had been teaching the Old Greek language for about 40 years.

Lvivuniversity was and is one of the mightiest centers of Hellenistic studies. A prominent classical philologist, mycologist S. Lurje beginning from 1953 had been heading the classical department in Lviv University. He is the author of the first written out of Greece monograph "Language and Culture of Mycenaean Greece" (1957). It is hard to overestimate the contribution into the development of Hellenistic Studies of such scholars as J. Kobiv, A. Sodomora, 
L. Glushchenko, B. Cherniukh and other Lviv classics.

From the sixties of the XX-th century there began the history of the New Greek teaching in Kyiv University. It is closely connected with the activities of A. Biletskiy and and T. Chernyshova. Starting from 1958 they prepared about 57 neohellenists. Among them such prominent scholars as O. Ponomariv and N. Klimenko who were the founders of the Chair of Hellenistics in Kyiv National University in 1999. Since then the New Greek language is taught as the first language (as the second it started in 1995 at the Department of foreign philology). Thanks to the efforts of professors O. Ponomariv, N. Klimenko, F. Nikitina, Greek embassy in Ukraine the Chair of Hellenistics had been founded and made a great contribution into the development of Hellenistic studies in Ukraine. A new generation of Hellenists was prepared. It is now represented by young, but in the same time already experienced scholars as A. Savenko, S. Perepliotchikova, A. Stoliarova, T. Liubchenko and many others.

After this short introduction into the history of the Greek language teaching in Ukraine I'd like to pay some attention to the scientific studies of the New Greek language in modern Ukraine.

This trend might be divided into two streams:

1. Translation Studies presented by A. Savenko, translator and researcher of literary works of the prominent Greek writers Nikos Kazandzakis and StratisMiryvilis. To this stream also belongs the scientific activity of S. Perepliotchikova, who analized the translations of N. Kazandzakis novels into Ukrainian.

2. Studies in the New Greek language which in their turn might be divided into such three substreams as: 1) language as a function; 2) language's realization in speech under the pragmatic point of view; 3) language as a bearer of ethnic mentality and culture. All of these substreams were headed by the prominent Ukrainian scholar N. Klimenko who has recently passed away leaving behind the mighty scientific methodological background for the further effective studies in the field of neohellenistics.

Let's take a look into each of them.

Being a specialist in the field of general linguistics I'd like to deal primarily with the studies in the sphere of linguistics' theory.

Актуальні проблеми мовознавства [Актуальные проблемы языкознания] СГолубовська I. О. [Голубовская И. A.], igolubovska777@gmail.com Як вивчається та досліджується грецька мова в Україні (3 нагоди Міжнародного дня грецької мови 9.02.19.) [Как изучается и исследуется греческий язык в Украине (к Международному дню греческого языка 9.02.19.)] (Англійською / На англ. яз) 
Language as a function. The thesis for the Candidate degree in Philology "Transitivity as a Type of Verb Valency in Modern Greek"(2009)by T. Liubchenko, within which the major types of predicates characteristic for the New Greek language are presented, the interaction between transitivity and verb valency is also shown.

Within the Thesis for the Candidate degree in Philology "Syntax of the Accusative Case in Modern Greek" (2009) by Z. Pavlovska the Accusative case functions were described in the context of diachronic transferring of Genitive and Dative cases functions in the Old Indoeuropean language to the Accusative case in the New Greek. The updated semantic classification of the verb predicatives governing the Accusative case is being presented. It is proved that in Modern Greek language the ergative system of the Old Indoeuropean language is reconstructed with the help of special class of verbs (ergative and transmissive).

Thesis for the Candidate degree in Philology "Grammatical Gender in the System of Noun Categories in Modern Greek” (2011) by O. Tyshchenko. This category is described in the context of its semantization and lexicalization. It is shown that this grammatical category is in unstable and variable state thanks to the coexistence in Modern Greek of demotic and catharevousa.

Thesis of V.Ardonceau "Semantic and Syntactical Structure of Impersonal Sentences in Modern Greek" is devoted to the study of the peculiarities of impersonality category in Modern Greek language. It is done in the terms of functional-semantic field; the center and the periphery of this field are being modeled on the grounds of the lingual forms' belonging to morphological, lexical, syntactic and phraseological language levels. The reasons of infinitive disappearance which had a direct impact on the category of impersonality in Modern Greek are being investigated.

Thesis by M. Kositskyy "Analitical and Synthetical Tendencies in Morphology and Compounding of the Modern Greek Language" (2015) focuses on analytical and synthetical peculiarities of Modern Greek language which are characteristic for the morphological and word-formative levels. The phenomenon of analyticity and syntheticityis shown on the different levels of language structure.

Language's realization in speech under the pragmatic point of view. Thesis of A. Stoliarova "A Communicative and Pragmatic Aspects of the New Greek Legislative Documents (based on the Greek Criminal Code, the Code of 
Criminal Procedure and Other Legal Texts) (2007) is focused on the analysis of communicative and pragmatic peculiarities of the Modern Greek legislative texts. Lingual means of cohesion and coherence are being studied in the context of their macrostructure on the material of the legislative documents. This stuff is also considered under pragmatic point of view; such metalanguage as the addresser, the addressee, the communicative intention, the pragmatic goal, the presupposition, which mark a pragmatic approach, are used for the purposes of the pragmatic analysis. This linguistic work done on the material of Modern Greek language appeared to be the first in Ukraine which had as its methodological background the ideas of communicative linguistics, pragmatics and textology.

Language as a bearer of ethnic mentality and culture. Thesis of Y. Zharikova "The Rumeic Phraseology in its Relation with the Ukrainian and Greek Phraseological Systems" (2013) is devoted to the peculiarities of Azov Greeks' language functioning in Ukraine. The author's attention is focused on the phraseological systems of the three languages - Rumeic, Modern Greek and Ukrainian. Both structural and anthropological approaches are being exercised, i. e. synonymy, antonymy, polysemy, thematic groups of phraseological units are being studied alongside with features of ethnic mentality conveyed with the help of phraseological entities of the three languages.

And, finally, the thesis of Y. Kozhukhovska"Concept JOURNEY in Modern Greek Poetry of the XX-th century: aspects of culture and ethnolinguistics" (2018) is completed in the frames of the anthropological linguistics and is devoted to the study of the ways of verbalization of the concept JOURNEY on Modern Greek linguoculture on the basis of poetical discourse. The author comes up with conceptual cognitive analysis fulfilled with the help of the frame-slot modeling. This linguistic work appears to be the first one inspired by cognitive ideas (highly characteristic for the contemporary linguistics) and accomplished on the material of Modern Greek language.

So, as we have seen, there was and there still exists the mighty tradition in Greek language teaching and Greek language investigation in Ukraine. The logic of the strengthening friendship relations between our countries puts forward the urgent need in the further development of cross-language and cross-cultural Greek-Ukrainian links.

Актуальні проблеми мовознавства [Актуальные проблемы языкознания] СГолубовська I. О. [Голубовская И. A.], igolubovska777@gmail.com Як вивчається та досліджується грецька мова в Україні (3 нагоди Міжнародного дня грецької мови 9.02.19.) [Как изучается и исследуется греческий язык в Украине (к Международному дню греческого языка 9.02.19.)] (Англійською / На англ. яз) 
УДК 811.134.2'373

\title{
МОРБІАЛЬНА МЕТАФОРА В ЕКОНОМІЧНОМУ ДИСКУРСІ СУЧАСНИХ ІСПАНОМОВНИХ ЗМІ
}

\section{Васильєва Тетяна Олександрівна, tatikievita@gmail.com}

\author{
к.філол. наук, доцент
}

кафедри іноземних мов і міжкультурної комунікації

Київський національний економічний університет імені Вадима Гетьмана

Статтю присвячено дослідженню функиіонування морбіальної метафори в економічному дискурсі сучасних іспаномовних ЗМI. Матеріалом наукових розвідок є статті економічної тематики, опубліковані в розділі «Економіка» іспаномовних періодичних інтернет-видань. Для дослідження обрано період з 2008 року, початку глобальної економічної кризи, по теперімній час. Вивчено структуро-семантичні властивості морбіальної метафори, джерелом експансії якої є поняттєва сфера ХВОРОБА. Основним методом дослідження обрано метод метафоричного моделювання. Увагу акцентовано на визначенні основних моделей морбіальної метафори, які мають фреймово-слотову структуру, та виявлено мовні засоби їх відтворення. Здійснено структурний аналіз фреймів, в яких економічні установи представлено як пацієнтів, щчо потерпають від хвороб, які є метафоричним переосмисленням негативних явищ в економічі, і потребують лікування. 3'ясовано, щуо морбіальна метафора в іспаномовному економічному дискурсі представлена п'ятьма основними фреймами: "Пацієнти $i$ лікарі», "Діагноз», "Симптоми хвороби», «Лікування» $i$ «Стан хворого». У межах кожного фрейму виділено основні слоти $і$ описано їх лексичне наповнення. Визначено комунікативні функиї морбіальної метафори в іспаномовному економічному дискурсі в період кризи та під час виходу з неї, а також з'ясовано причини ії активізачї. Зроблено висновок, що фреймово-слотова структура морбіальної метафори відображає негативні явища глобальної економіки, представлені в іспаномовному медійному дискурсі, i свідчить про активізачію використання досліджуваної метафори в період загострення економічної кризи та боротьби з ї наслідками. З'ясовано, що в об'єктивації концептів поняттєвої сфери ЕКОНОМІКА під час загострення економічної ситуаџіï $i$ стану кризи переважають негативно-оцінні метафори хвороб та їх симптомів, а в посткризовий період - позитивно-оцінні метафори позитивного впливу обраних методів лікування та одужання економіки. 
Ключові слова: концептуальна метафора, сфера-джерело, сфера-мішень, метафорична модель, фрейм, слот.

\title{
МОРБИАЛЬНАЯ МЕТАФОРА В ЭКОНОМИЧЕСКОМ ДИСКУРСЕ СОВРЕМЕННЫХ ИСПАНОЯЗЫЧНЫХ СМИ
}

\author{
Васильева Татьяна Александровна, tatikievita@gmail.com \\ к.филол.наук, доцент \\ кафедры иностранных языков и межкультурной коммуникации
}

Киевский национальный экономический университет имени Вадима Гетьмана

Статья посвящена исследованию функционирования морбиальной метафоры в экономическом дискурсе современных испаноязычных СМИ. Материалом исследования избраны статьи экономической тематики, опубликованные в разделе «Экономика» испаноязычных периодических интернетизданий. Для исследования выбран период с 2008 года, начала глобального экономического кризиса, по настоящее время. Изучень структурносемантические свойства морбиальной метафоры, источником экспансии которой является понятийная сфера БОЛЕЗНЬ. Основным методом исследования является метод метафорического моделирования. Внимание акиентируется на определении основных моделей морбиальной метафоры, имеюших структуру фреймов и слотов, а также на анализе языковых средств их актуализации. Осуществлен структурный анализ фреймов, в которых объекты экономики представлень как пациенты, страдающие болезнями, являющимися метафорическим переосмыслением негативных явлений в экономике, и нуждаюшихся в лечении. Как показал анализ текстов, опубликованных за указанный период, морбиальная метафора в испаноязычном экономическом дискурсе представлена пятью основными фреймами: «Пачиенть и врачи», «Диагноз», «Симптомы болезни», «Лечение» $и$ «Состояние больного». В каждом фрейме выделены основные слоты и описано их лексическое наполнение. Выяснены коммуникативные функиии морбиальной метафоры в испаноязычном экономическом дискурсе в период кризиса и во время выхода из него, а также причины ее активного использования. Сделан вывод, что фреймово-слотовая структура морбиальной метафоры, представленной в испаноязычном медийном дискурсе, актуализирует негативные явления, происходящче в глобальной экономике, и свидетельствует об активизации использования исследуемой метафоры в период обострения экономического кризиса и борьбы с его последствиями. Установлено, что в объективаџии концептов понятийной сферы «ЭКОНОМИКА» во время обострения экономической ситуаџии и кризиса 
преобладают негативно-оченочные метафоры болезней и их симптомов, а в посткризисный период - позитивно-оченочные метафоры положительного эффекта выбранных методов лечения и оздоровления экономики.

Ключевые слова: концептуальная метафора, сфера-источник, сферамишень, метафорическая модель, фрейм, слот.

\title{
MORBIAL METAPHOR IN ECONOMIC DISCOURSE OF THE MODERN HISPANIC MEDIA
}

\author{
Vasylieva T., tatikievita@gmail.com \\ $\mathrm{PhD}$ (Philology), Associate Professor of the \\ Department of Foreign Languages and Intercultural Communication \\ Kyiv National Economic University named after Vadym Hetman
}

The present paper deals with the functioning of the morbial metaphor in the economic discourse of contemporary Hispanic media. The articles of economic topics, published in the section "Economics» of Hispanic periodical Internet publications are been chosen as the material of this scientific research. The period from the beginning of the global economic crisis (2008) to our days is been selected for this investigation. The structural-semantic properties of the morbial metaphor, which source domain is DISEASE, is being studied. The main method of the research is the metaphorical modeling. The emphasis is on determining the basic models of a morbial metaphor, which have a frame-slot structure, and language means of their reproduction. Structural analysis of frames present economic institutions as patients suffering from diseases, which are the metaphorical rethinking of negative phenomena in the economy, and need treatment. It has been found that five main frames represent the morbial metaphor in the Hispanic economic discourse: "Patients and doctors", "Diagnosis", "Symptoms of illness", "Treatment" and "Health status of the patient". Within each frame, the main slots are highlighted and their lexical content is described. The communicative functions of the morbial metaphor in the Hispanic economic discourse during the crisis and the causes of its activation have been determined. It was concluded that the frame-slot structure of the morbial metaphor reflects the negative phenomena of the global economy, presented in the Hispanic media discourse, and indicates the intensification of the use of the metaphor under study in the period of the aggravation of the global economic crisis and combating its effects. It was found out that the actualization of concepts of the conceptual sphere ECONOMY during the aggravation of the economical situation is dominated by the negative evaluative metaphors of the domain ILLNESS AND THEIR SYMPTOMS, and in the post-crisis period, - by the positively evaluative 
metaphors of the positive influence of the chosen methods of TREATMENT and RECOVERY of the economy.

Key words: conceptual metaphor, source domain, target domain, metaphorical model, frame, slot.

\section{ВСТУП}

У сучасній лінгвістиці спостерігається значний інтерес до когнітивної метафори та ii прагматичного потенціалу в різних типах дискурсів. Метафора, як ментальний i лінгвальний феномен, $\epsilon$ інструментом концептуалізації дійсності i формування світогляду людини. Антропоцентрична за своєю природою свідомість людини дозволяє їй переосмислювати усі абстрактні явища за аналогією з об'єктами реальної дійсності через схожість певних ознак цих явищ із ознаками реальних об'єктів, добре ій відомих.

Зміни, які відбуваються в сучасній економічній ситуації, призводять до необхідності їі осмислення в нових термінах і поняттях. Відбувається активний процес збагачення лексики за допомогою вторинної номінації. Тому саме метафора як один із фундаментальних прийомів пізнання i концептуалізації дійсності набуває найбільшого поширення в економічному дискурсі.

У центрі нашого дослідження - морбіальна метафора, що $\epsilon$ різновидом антропоморфної метафори, вихідною сферою чи сфероюджерелом якої виступає поняття ХВОРОБА.

Актуальність обраної теми дослідження зумовлено загальною спрямованістю сучасних лінгвістичних досліджень на аналіз функціонування мовних одиниць із урахуванням їх лінгвокогнітивних та комунікативно-прагматичних особливостей з позиції антропоцентризму.

Мета дослідження - виявити структурно-семантичні та функціональні особливості морбіальної метафори в сучасних іспаномовних текстах економічного медійного дискурсу, дослідити іï роль в концептуалізації економічних понять та реалій світової економіки. Для цього необхідно виокремити і класифікувати іiї основні метафоричні моделі, описати засоби їх вербального втілення та виявити прагматичний потенціал.

Об’єкт дослідження становлять тексти, розміщені в розділі «Економіка» іспаномовних загальнонаціональних періодичних Інтернет- 
видань та в спеціалізованих економічних періодичних виданнях, розміщених в Інтернеті. Предметом обрано метафоричні моделі морбіальної метафори зі сферою-джерелом ХВОРОБА, виявлені в економічних текстах.

Матеріалом дослідження слугували тексти економічної тематики, опубліковані в періодичних інтернет-виданнях Іспанії та Латинської Америки (elpaís.com, eleconomista.es, elmundo.es, larazon.es, АBC.es, eldiario.es, 20minutos.es, expancion.com, expancion.mx, lavoz.com.ar, cronista.com, jornada.com.mx, es.euronews.com).

Морбіальна метафора неодноразово ставала предметом аналізу в працях вітчизняних та закордонних лінгвістів. У сучасній лінгвістиці існують наукові студії, присвячені вивченню функціонування морбіальної метафори в політичному дискурсі на прикладі англійської та німецької мов (I. Телешева, М. Жулінська, Н. Смоляр), в російському і британському управлінському дискурсі (О. Юдіна), в представленні системи освіти в британських ЗМІ (М. Вавіліна), автомобільному медіадискурсі в німецькій та російській мові (Ю. Ревіна). Дослідниця Alice Stender здійснює аналіз корпусу метафори SALUD/ЗДОРОВ'Я в фінансово-економічних текстах періодичних видань в іспанській та німецькій мовах за допомогою квантитативного та компаративного методів [Spencer 2015]. Незважаючи на значний ступінь зацікавленості мовознавців у дослідженні функціонування морбіальної метафори в різних типах дискурсу, в іспаністиці немає праць, в яких би іiі було досліджено методом когнітивно-метафоричного моделювання, що передбачає аналіз кожної метафоричної моделі 3 урахуванням її фреймово-слотової структури, опис її лексичного наповнення та з’ясування iï прагматичної функції.

Наше дослідження виконано в рамках теорії концептуальної метафори та присвячено метафоричному моделюванню дійсності в межах економічного медійного дискурсу. Теоретичним підгрунтям наших розвідок стали праці науковців, присвячені дослідженню економічного дискурсу та концептуальній метафорі, - основними поняттями, якими ми оперуємо у цій роботі.

Економічний дискурс $є$ окремим видом інституційного дискурсу. Водночас деякі мовознавці вважають його складовою політичного дискурсу (О. Чудінов, А. Баранов, О. Шейгал), ділового чи бізнес-дискурсу (C. Наумова, Н. Щокіна, Р. Пилипенко, Р. Кадимова). Слідом за 
Т. Свтушиною i Н. Ковальською, визначаємо економічний дискурс як “сукупність мовленнєвих актів у сфері економіки, а також створені професіоналами, неспеціалістами та журналістами усні та письмові тексти чи їх фрагменти, які відображають реалії економічного світу” [Євтушина, Ковальська 2014,44]. Водночас існують підвиди економічного дискурсу, створені його контамінацією іншими видами дискурсів. Наприклад, економічний дискурс преси чи медійний економічний дискурс, який $є$ поєднанням економічного і медійного дискурсу, адресатом якого є масова аудиторія, а каналом комунікації - засоби масової інформації. ЗМІ повідомляють про факти і події у світі економіки, висвітлюють глобальні процеси в світовій економіці та формують ціннісне ставлення до них, сприяють певній оцінці цих подій і процесів соціумом як адресатом. Російська дослідниця О. Петушинська розглядає контамінацію медійного й економічного дискурсів як популярний економічний дискурс, створений засобами масової інформації, комунікативним завданням якого слід визнати необхідність не лише довести інформацію до адресата, але й вплинути на його думку та примусити до певних дій [Петушинська 2008].

Тексти, що розглядаються в статті, належать до популярного економічного дискурсу. Специфічність лексичного оформлення популярних економічних текстів полягає в поєднанні загальновживаної лексики, загальнонаукової та спеціальної термінологічної. Особливістю популярних економічних текстів $є$ живі метафори, які базуються на щоденних, повсякденних концептах життя людини, і в переосмисленому вигляді співвідносяться із концептами економіки.

3 точки зору когнітивної лінгвістики метафора є потужним засобом об’єктивації абстрактних понять та концептів. М. Джонсон та Дж. Лакофф, вчені, що започаткували теорію когнітивної метафори, вважають ії способом "структурування нашого сприйняття, нашого мислення та наших дій" [Джонсон, Лакофф 2004, с. 25]. Процес пізнання навколишнього світу відбувається за допомогою "осмислення та переживання явищ одного роду в термінах явищ іншого роду" [Джонсон, Лакофф 2004, с. 27]. Метафора як ментальна оперативна одиниця об'єднує сферу-джерело, той простір, який $є$ донором, та сферу-мішень, простір, який запозичує поняття донорської сфери. Елементи сфери-джерела структурують менш зрозумілу сферумішень, що і складає суть когнітивного потенціалу метафори. 
Для дослідження метафори ми скористалися методом метафоричного моделювання, розробленого М. Джонсоном і Дж. Лакоффом, який отримав подальший розвиток у працях А. Баранова, Ю. Караулова, І. Кобозевої, А. Чудінова, М. Тернера, Ж. Фоконьє та інших дослідників. Як зазначає А. Чудінов, "метафоричне моделювання - це засіб усвідомлення, рубрикації, представлення та оцінки певного фрагменту дійсності, що відображає його національну, соціальну i особистісну самосвідомість за допомогою сценаріїв, фреймів і слотів, які належать до іншої поняттєвої сфери" [Чудінов 2001, с. 47].

Проаналізувавши статті за період з 2008 року по теперішній час, який співпадає із початком глобальної економічної кризи та виходу з неї, ми спостерігаємо підвищення інтенсивності використання морбіальної метафори в економічних текстах іспаномовних ЗМІ в період загострення кризи. На основі дослідження корпусу морбіальних метафор за зазначений період, ми висуваємо гіпотезу про застосування даної метафори адресантом не лише для експресивності та зрозумілості економічних текстів широкому колу читачів, що не мають спеціальної економічної освіти, але й для впливу на свідомість адресата, намагання переконати його у необхідності вживання непопулярних заходів, що призводять до тимчасового погіршення економічної ситуації у суспільстві, з метою виходу з економічної кризи, порівнюючи непопулярні заходи 3 прийняттям ліків, які позитивно впливають на людський організм.

\section{ОСНОВНИЙ ЗМІСТ}

Поняттєва сфера морбіальної метафори $є$ доволі продуктивною та насиченою. В економічних текстах іспаномовних ЗМІ зазначена метафора представлена метафоричною моделлю ЕКОНОМІКА - ХВОРИЙ ОРГАНІЗМ. Відповідно до цієї моделі в поняттєвій сфері ЕКОНОМІКА використовується лексика хвороб, їх лікування та одужання або смерть хворого. Ця метафора значно активується під час економічної кризи, тому що, як зазначає Ст. Ульман, джерелом метафоричної експансії завжди $є$ семантичні сфери, яким суспільство приділяє особливу увагу. Однією із таких сфер є здоров'я людини. Погіршення економічної ситуації у країні та світі впливає на добробут людини [Ульман 1970, с. 253]. Тому стає зрозумілим така активізація морбіальної метафори у період економічної кризи. Як зазначає О. Чудінов, метафорична модель цього типу має 
емотивний характер. Метою ії використання $є$ перенесенням ставлення адресанту до хвороб у поняттєву сферу економіки з метою викликати у нього тривожне ставлення до економіки країни, навіть співчуття, та налаштувати адресата на тривалий період лікування, який потребуватиме терпіння та витримки для одужання пацієнта, тобто економіки [Чудінов 2001, c. 73].

Зазначена модель представлена наступними фреймами: 1. Пацієнти та лікарі. 2. Діагноз. 3. Симптоми хвороби. 4. Лікування. 5. Стан хворого. У межах кожного із фреймів виділено основні слоти та описано їх лексичне наповнення.

Фрейм 1. "Пацієнти і лікарі” представлено слотами 1.1. “Пацієнти” і 1.2 “Лікарі".

Слот 1.1. "Пацієнти”. В економічних текстах ЗМІ Іспанії економіку різних країн, в першу чергу європейських, представлено як пацієнта, хворого, чиє захворювання $є$ заразним і тому становить небезпеку для інших організмів. Часто економіка країни метонімічно позначається назвою країни. Так, Франція, Італія, Іспанія є метонімічною назвою економік зазначених країн: Francia e Italia, los enfermos que amenazan el crecimiento económico de la Eurozona (eleconomista.es, 17.02.15). Los economistas consultados coinciden en el diagnóstico: España es un enfermo grave que debe sobrevivir con menos crédito. Europa debe culminar el saneamiento de su sistema bancario (elpais.com, 17.04.13). У цьому прикладі пацієнтом вважається економіка Європи, яка повинна закінчити оздоровлення банківської системи, що асоціюється із життєво важливим органом в іiї організмі.

Окрім концепту ЕКОНОМІКА в межах однойменної поняттєвої сфери можливе метафоричне перенесення концепту ПАЦІЕНТ на фінансово-економічні установи: banco enfermo / saneado / contagiado; bolsa enferma, el estornudo de la bolsa de valores; mercado contagiado/saneado; empresa expuesta a contagio та грошові одиниці: euro /dólar /peso contagiado / enfermo / débil.

Tenemos tres magnificos bancos saneados y con liquidez (elpaís.com, 21.03.13). El dólar sumó 40 centavos contagiado por caída de otras monedas regionales (cronista.com, 24.10.18).

Слот 1.2. “Лікарі”. Зазвичай “лікарями” економіки постають інспектори: президенти Міжнародного Валютного Фонду, Центрального 
Європейського Банку та Європейської комісії, яких в іспаномовному масмедійному дискурсі представлено номенами "tecnócratas profesionales"; епітетом "incorruptibles"; алюзивними антропонімами "hombres de negro", натякаючи на героїв однойменної кінострічки, які рятують планету від прибульців; та "troika" (алюзія на трьох керівників колишнього СРСР президента країни, голову уряду і генерального секретаря КПРС, які вирішували долю країни). Таке метафоричне перенесення пояснюється тим, що трійця керівників МВФ, ЦСБ та Європейської комісії приїздить у країни, що потерпають від економічної кризи, та після ретельного аналізу їх економічної ситуації пропонує їм допомогу за умов проведення низки реформ для покращення основних економічних показників. Іншим “лікарем” виступає Єдиний комітет 3 врегулювання - la Junta Unica de Resolución, місія якого полягає в вирішенні проблем банків у кризовій ситуації 3 мінімальним впливом на фінансову систему інших країн $\mathrm{CC}$.

Tecnócratas profesionales ... . Son incorruptibles, no negocian. Son los hombres de negro (elmundo.es, 24.08.12). La comisión del Congreso encargada de investigar la crisis financiera y el rescate de las cajas de ahorros ha acordado citar a los conocidos como 'hombres de negro' que se ocuparon del rescate financiero de España (la 'troika' formada por el FMI, el MEDE y la CE) y a la presidenta de la Junta Unica de Resolución (JUR), Elke König, la responsable europea que puso en marcha el proceso de la venta del Banco Popular ... puso en cuarentena al Banco POPULAR hasta que acabó siendo vendido al Santander (eleconomista.es, 29.06.17).

Фрейм 2. “Діагноз”. Аналіз метафоричних образів в іспаномовних медійних текстах, присвячених питанням економіки, виявив, що під час погіршення економічної ситуації економіці та іiі установам приписуються різні захворювання. Головною хворобою економіки $є$ економічна криза, побічними ефектами якої виступають інфляція, безробіття, банкрутство. Усі види захворювань можна розподілити на фізіологічні, психічні та інфекційні.

Слот 2.1. “Фізіологічні захворювання”. Здебільшого це захворювання верхніх дихальних шляхів. Найпоширенішою метафоричною моделлю в межах цього слоту $\epsilon$ ЕКОНОМІЧНА КРИЗА ЗАСТУДА / ЗАПАЛЕННЯ ЛЕГЕНІВ. СТупень тяжкості хвороби відображає ступінь масштабності фінансово-економічної кризи: Economía mexicana 
¿pulmonía o 'catarro'? Una recesión en EU o un impago griego podrían desatar una crisis en México, afirma Sergio Negrete (expancion.com, 20.09.11). Siemens, ¿resfriado o crisis existencial? (elpais.com, 04.08.2013) Señales de la constipación económica_aparecen por todos lados (lavoz.com.ar, 27.04.14).

Завдяки метафоричному перенесенню із сфери-джерела ХВОРОБИ адресантом економічних текстів використовується також лексика на позначення захворювань опорно-рухової системи, які призводять до деформації кісток та ускладнення довільного руху або повної його втрати: raquitis, parálisis. La economía aragonesa sufrirá otro año más de parálisis y desempleo (elperiodicodearagon.com, 07.10.10). У наведеному прикладі адресант ставить діагноз економіці автономної спільноти Арагон - параліч та безробіття, поняття, позначені лексемами, які належать до різних лексико-семантичних полів, поєднані в одному реченні. Економіка регіону, що втрачає динаміку, порівнюється із хворим організмом, розбитим паралічем. Побічним ефектом цього захворювання є безробіття.

El mercado de la vivienda padece raquitismo en el Principado. El anuario de los Registradores coloca a Asturias como la región que menos operaciones de compraventa realizó por habitante a lo largo de 2014 junto a Galicia (elmundo.es, 25.04.16). Недостатня кількість операцій купівлі продажу на ринку нерухомого майна дає підстави адресанту порівнювати ситуацію на ринку із захворюванням на рахіт, спричиненим дефіцитом вітаміну Д в організмі.

Доволі поширеним є актуалізація кризового стану економіки за допомогою лексеми 'anemia': Es dificil recordar una coyuntura externa así para el crecimiento español. Incluyendo los peros que quieran: anemia de la economía europea, caída de los emergentes, reveses latinoamericanos, nubarrones geoestratégicos... que pueden gestar un sincope (elpais.com, 18.12.15).

Для усвідомлення адресатом серйозності ситуації, в якій опинилась економіка країни внаслідок економічної кризи, що загрожує колапсом, адресант послуговується лексемами донорської сфери на позначення невиліковних хвороб: $\boldsymbol{E l}$ 'cáncer' se descubrió en mayo de 2010, cuando Grecia reveló el estado de sus finanzas y recibió un rescate por 159,000 millones de dólares (expansión.com, 20.05.11). 
Цікавим є вживання поняття 'enfermedad holandesa' чи 'resfriado holandés'.¿Padece de enfermedad holandesa la economía colombiana? (elpais.com.co, 08.07.12) Зазначений термін використовується на позначення типу ведення економіки, де левову частку доходів країна отримує від експорту сировини, витрачаючи їх потім на імпорт товарів, щоб задовольнити потреби населення у продуктах та послугах. При цій моделі економіки власне виробництво майже не розвивається.

Слот 2.2. "Психічні захворювання" включає лексичні одиниці, які номінують психічні розлади такі, як шок, стрес, маразм, наркотична залежність, які переносяться в концептуальну сферу ЕКОНОМІКА. Цікавим $\epsilon$ поєднання лексеми сфери-джерела із атрибутом сфери-мішені (shock financiero, estrés bancario): "Un amplio, adverso y persistente shock financiero como el que comenzó a finales del 2008 podría resultar en una economía más lenta con menos contrataciones y un mayor desempleo que lo que debería ser" (abc.com, 03.10.13). Todo parece indicar, conocidas la semana pasada las condiciones que se aplicarán al ejercicio de estrés bancario que se va a realizar en la Unión Europea, que no se repetirán errores pasados (abc.es, 6.05.14). Хронічна криза в європейських країнах порівнюється із маразмом, що погіршує прогнози про вихід економіки із затяжної кризи: La de Europa es una crisis crónica: mientras el resto del mundo ha salido del pozo, la eurozona se ha quedado atascada en un deprimente marasmo, un estado de sitio del que apenas se adivina la futura recuperación (elpais.com, 12.10.13).

Розвиток економіки за рахунок видобутку та експорту сировини негативно впливає на виробництво власної продукції. Негативна оцінка цій тенденції надається адресантом порівнянням із наркотичною залежністю: Rusia padece la dependencia del petróleo y el gas para su crecimiento. (es.euronews.com, 19.04.13).

Слот 2.3. "Інфекційні захворювання". У цьому слоті в межах метафоричної моделі КРИЗА - ІНФЕКЦІЙНЕ ЗАХВОРЮВАННЯ адресант концептуалізує реакцію фінансово-економічних установ світу на погіршення економічної ситуації в окремій країні за допомогою лексем інфекційних захворювань 'contagio', 'contagioso', 'contagiarse', 'epidemia' для експресивної передачі миттєвого реагування ринків, банків та бірж на загрозу кризи: Wall Street sufrió hoy una paliza, motivada por la continuación de los problemas en los países emergentes, que se han contagiado a través de 
diversos caminos a los mercados neoyorquinos (expansion.com, 24.01.14). El Fondo Monetario Internacional (FMI) ha expresado su preocupación ante el riesgo de contagio "notable" de la crisis italiana a aquellas economías europeas en peores condiciones macroeconómicas y menor margen fiscal (republica.com, 08.11.18). МВФ, як лікар, схвильований ризиком зараження європейських економік інфекційним захворюванням, на яке страждає італійська економіка.

Фрейм 3. “Симптоми хвороби”. Часто негативні процеси в економіці постають у вигляді симптомів хворобливого стану. Це такі прояви захворювань як чхання та кашель при застуді; кровотеча при пораненні; шрами від рани, що ще не зовсім загоїлась; новоутворення, появі яких передував прихований період захворювання; та метастази, що свідчать про серйозну загрозу “здоров”ю” економіки : Cuando China estornuda, el mundo se resfría (abc.es, 29.10.12) La City está estornudando por la incertidumbre del qué pasará, y como el Gobierno ni sabe ni contesta, ha decidido ponerse en lo peor (elpais.com, 07.08.17). El resfriado chino -o lo que sea, que los expertos no se ponen muy de acuerdo- ya está provocando compulsivos ataques de tos en todo Occidente. Por ahora, bursátiles. Pero la crisis no se detiene y, pese a ese esfuerzo, la herida sigue sangrando (elpais.com, 10.03.13). Lo más probable es que se apruebe un rescate, pero la pésima gestión de la crisis chipriota por parte de las autoridades europeas dejará cicatrices aunque llegue el acuerdo porque la burbuja es un tumor lento (nación.com, 30.03.15). El problema es que la metástasis ya se ha expandido por todo el sistema financiero mundial (elpais.com, 03.11.11).

Симптом болі актуалізовано за допомогою дієслів sufrir, padecer:_El dólar_estadounidense estaba sufriendo hoy en los mercados internacionales (elEconomista 25.01.18).

Фрейм 4. “Лікування”. Економічна ситуація, метафорично представлена у вигляді хвороб, потребує медикаментозного лікування та оперативного втручання. Зазначений фрейм в іспаномовному економічному дискурсі сучасних ЗМІ можна представити двома слотами “Ліки” та "Методи лікування".

Слот 4.1. “Ліки” представлено лексемами 'tratamiento', 'cura', 'medicina', 'receta', 'remedio eficaz', 'sanguijuelas', 'contraindicaciones', 'efectos colaterales'. У більшості випадків найкращими ліками, що 
прописують “лікарі” економіці для покращення ії стану здоров'я, є сувора економія, нульові ставки та вливання капіталу. Проте, прописані ліки мають також побічні ефекти та протипоказання. Інколи ліки можуть бути доволі екзотичними, як, наприклад, п'явки, які ставляться для припинення кровотечі у хворого. Eso es como aplicar sanguijuelas a un paciente que sangra. Es un milagro que la economía de EE.UU. al menos haya podido renquear hasta aqui (progresosemanal.us, 12.07.13). La cura prescrita es austeridad (un término más suave para decir deflación), pero las democracias no son buenas en esa práctica (expansión.com, 20.05.11). Para seguir con la alusión a la medicina, después del colapso de 2008, los bancos centrales del mundo desarrollado recetaron a sus maltrechas economías un remedio muy fuerte: para contrarrestar los efectos de la crisis aplicaron de manera persistente tasas de interés cercanas a cero (e incluso negativas en algunos casos) e inyectaron cantidades astronómicas de liquidez al sistema financiero. Pero esa medicina tenía contraindicaciones y efectos colaterales indeseables (jornada.com.mx, 17.10.18).

Слот 4.2. “Методи лікування". Лексичне наповнення цього слоту представлено здебільшого словосполученнями contener / frenar la sangría, detener el flujo, taponar la hemorragia, що свідчить про те, що економіку актуалізовано як пораненого пацієнта, у якого сильна кровотеча, що знесилює його організм. Тому перший етап лікування економіки полягає в припиненні кровотечі і переливанні крові, де кров є метафоричним перенесенням у сферу DINERO / ГРОШІ: El banco central chino baja los tipos de interés para intentar contener la sangría de las bolsas (17.10.18). El tratamiento a un paciente que pierde sangre es detener el flujo y suministrar una transfusión. El tratamiento para una economía que sangra empleos, es que el gobierno suministre una transfusión en la forma de consumo incrementado. Los grandes bancos españoles han hecho un esfuerzo tremendo el pasado año por intentar taponar la hemorragia de pérdidas por los créditos concedidos a los promotores en tiempos de la burbuja inmobiliaria. Наступним етапом лікування економіки є крапельниці та ін'єкції для одужання пацієнта - банків, бірж, ринків, де ін'єкції теж $є$ метафоричним осмисленням поняття DINERO / ГРОШI: Los mercados juegan infiltrados en todo el mundo gracias a las inyecciones de liquidez de los grandes bancos centrales, que han evitado lo 
peor, pero las autoridades se empiezan a preocupar por lo que ocurra cuando estos estímulos se retiren (elpais.com, 17.04.13).

Необхідність рішучих дій для порятунку глобальної економіки під час фінансово-економічної кризи, яка охоплює все більше країн, адресант втілює метафоричним перенесенням лексем 'detección precoz', 'intervención quirúrgica' концептуальної донорської сфери CÁNCER / ОНКОЗАХВОРЮВАННЯ на сферу ЕСОNOMÍA / ЕКОНОМІКА, утворюючи метафоричну модель CRISIS / КРИЗА - CÁNCER/ PAK: Recientemente participé en un seminario con exministros de Economía iberoamericanos en el que contaban sus experiencias en gestión de crisis financieras. Como en el cáncer, es clave la detección precoz y una intervención rápida ... Y en el protocolo de intervención quirúrgica es fundamental mantener la calma (elpais.com, 03.11.11).

Фрейм 5. “Стан хворого”. Логічним завершенням будь-якої хвороби може бути одужання пацієнта або погіршення його стану. Зазначений фрейм представлено слотами “Погіршення стану”, “Одужання”, “Показники стану здоров'я".

Слот 5.1. "Погіршення стану". Якщо терапія, застосована до “хворої” економіки, не дає позитивного ефекту, можна казати про перехід хвороби у хронічний стан: España sale de la UVI pero sigue grave en paro, deuda y déficit (eleconomista.es, 02.11.17). Si los problemas de la economía productiva no se resuelven, la tregua finalizará y "la crisis financiera mundial podría entrar en una fase más crónica, caracterizada por un deterioro de las condiciones financieras y por episodios recurrentes de inestabilidad" (elpais.com, 17.04.13). El sistema financiero mundial continúa empeorando (elmundo.es, 08.10.08).

Інколи невчасна або некваліфікована медична допомога або ігнорування хворим призначеного лікування може призвести до його смерті: Si el BCE retira la manguera, la banca chipriota morirá de sed. ElIbex35 no da señales de vida: cae un $0.25 \%$ hasta los 9.507 enteros (eleconomista.es 14.08.18). ¿Por qué murió el Popular hace un año? Demasiados errores para un banco enfermo (elpais.com 07.06.18).

Слот 5.2. “Одужання". Вихід з економічної кризи метафорично описується як одужання хворого за допомогою лексем-іменників 'recuperación', 'mejoría', 'saneamiento', 'convalecencia' та похідних від них 
дієслів; виразів 'dar de alta', 'dar señales de vida', 'dar síntomas/signos de recuperación', 'detener sangría', 'salir de la paralisis'; дієприкметників 'saneado, recuperado, reforzado'. Процес одужання є поступовим і тривалим, тому не слід сподіватись на швидке покращення. Одужання економіки в цілому та економічних установ зокрема асоціюється із виходом хворого організму з коми, полегшеним скороченням м'яз та першими кроками після паралічу, зупиненням кровотечі, виходу 3 лікарняного: ...el mercado inmobiliario español está empezando a dar señales de vidas tras un desplome continuado durante siete años (eleconomista.es, 08.02.15); bolsas asiáticas detienen la sangría. ... la economía empieza a dar síntomas de cierta recuperación (eleconomista.es, 06.02.15). La economía empieza a mejorar, sí, pero el avance será "modesto" y muy prolongado en el tiempo. Está claro que 2014 empieza con signos claros de recuperación. Ahora bien, la situación actual de la economía española es como la de un enfermo que no hace mucho que salió de la UCI y con un largo periodo de convalecencia antes de que le den el alta médica (elpais.com, 26.06.13). España "está saliendo ya de la crisis con una economía saneada y reforzada" y consideró que América Latina ha tenido un papel muy importante en esa recuperación. (elmundo.es, 19.10.13), Ese estudio señala "que el saneamiento de la banca poco capitalizada ha alcanzado un nivel avanzado, Grecia ha comenzado a sacar la cabeza. El enfermo que hace unos meses estaba en coma inducido por los hombres de negro (Comisión, BCE y FMI) ha abierto los ojos. ;Milagro! Seguirá con respiración asistida durante meses, pero al menos ya no se teme por su vida, ni por su quiebra, ni por su salida del euro. La economía española está de nuevo en pie y en mejor forma que hace cinco años", ha espetado. (eleconomista.es 02.11.17). los mercados interbancarios van saliendo de la parálisis (elpais.com 16.10.08). Адресату натякають, що вихід із економічної кризи буде повільним і болючим. Потрібно набратись терпіння.

Слот 5.3. “Показники стану здоров'я”. Як тільки пацієнт захворів, необхідно провести низку досліджень та взяти аналізи для встановлення точного діагнозу. Як свідчать приклади, виявлені в економічних текстах іспаномовних 3МI, визначити стан “здоров'я” банків можна за допомогою стрес-тестування, аналізів на стійкість: La banca española supera los test de estrés en Europa con Banco Sabadell con la nota más baja. (eldiario.es 02.11.18). Pruebas de resistencia de la banca europea. Los cuatro bancos 
españoles superan los test de estrés elaborados por la Autoridad Bancaria Europea (elpais.com 02.11.18). Рентгенографія виявляе приховані хвороби інфляцію, безробіття: Radiografía de los precios en 2018: qué subió y qué bajó en la cesta de la compra (elpais.com 25.12.18) Radiografía de la banca a la espera de recuperar el favor del mercado (elpais.com, 12.10.18).

Важливим показником стану економіки та ії установ $є$ температура, яка визначається термометром. РІВ / ВВП стає джерелом експансії концепту TERMÓMETRO / TEPMOMETP: саме цей інструмент надає дані про стан здоров'я економіки. El PIB о Producto Interno Bruto es uno de los principales indicadores de la salud de una economía. (es.eronews.com 20.08.18). El PIB, ¿suficiente para medir la salud de la economía? (expansión.mx. 19.09.16). 250 inversores internacionales toman la temperatura a la economía española (elpais.com, 14.01.14).

Стан країни, зображений як хворий організм, змушує адресата негативно сприймати економічну ситуацію й особливо критично реагувати на процеси, що відбуваються в суспільстві. Проте, змальовуючи кризу та погіршення ситуації в фінансово-економічній системі як хвороби, адресант приховує вину керівників держав, банківських установ у доведенні стану економіки до серйозних збоїв, які впливають на рівень життя населення, пояснюючи помилки керівного менеджменту як симптоми хвороб, причина виникнення яких невідома. Єдине, що потрібно робити, - це набратися терпіння i дотримуватись приписаного лікарями режиму та методів лікування.

\section{ВИСНОВКИ}

На підставі розглянутого доходимо висновку, що морбіальна метафора широко використовується в текстах іспаномовних періодичних видань економічної тематики, особливо під час кризи та погіршення економічної ситуації у суспільстві, про що свідчить вибірка текстів із розділу «Економіка» іспанських та іспаномовних інтернет-видань, яка охоплює період з 2008 року по теперішній час, тобто період початку, кульмінації глобальної економічної кризи та етапу виходу із неї. Здійснений аналіз дав можливість виявити в іспаномовних медійних текстах економічної тематики структуру морбіальної метафори ECONOMÍA ORGANISMO ENFERMO, яку представлено п'ятьма фреймами: 1. Пацієнти та лікарі. 2. Діагноз. 3. Симптоми хвороби. 4. Лікування. 5. Стан хворого, 
котрі, в свою чергу, складаються 3 двох чи більше слотів. Як свідчать наведені у статті приклади, особливо продуктивними в межах метафоричної моделі ECONOMÍA - ORGANISMO ENFERMO $є$ метафора хвороб дихальних шляхів, когнітивні ознаки яких проектуються на важкий стан, який переживають об'єкти економіки. Серед основних функцій метафоричного перенесення зі сфери-джерела ENFERMEDAD у сферумішень у медійних текстах економічної тематики можна виокремити інформативну, метою якої є донесення до читача, який здебільшого не $є$ фахівцем в області економіки, інформації про економічну ситуацію та пояснення складних соціально-економічних явищ за допомогою зрозумілих адресатові прикладів зі сфери, в якій він має власний досвід. Іншою прагматичною функцією $є$ персуазивна, вплив на свідомість реципієнта із формуванням у нього потрібного замовнику текстів ставлення до економічних явищ i процесів. Перенесення концепту ORGANISMO ENFERMO на економіку із вживанням медичної термінології обгрунтовує важкий економічний стан як захворювання економіки, який потребує медичного втручання, котре часто $є$ болючим (погіршення матеріального стану), але необхідним для подальшого одужання пацієнта - виходу з кризи та економічного росту.

Метафоризацію основних понять досліджуваного дискурсу супроводжує позитивне і негативне аксіологічне забарвлення. В об'єктивації концептів ECONOMÍA, BANCO, MERCADO, BOLSA, DINERO під час кризи переважають негативно-оцінні метафори хвороб, натомість у післякризовий період - позитивно-оцінні метафори одужання. Морбіальна метафора в економічних іспаномовних текстах надає цінну інформацію про те, як осмислюються економічні явища і процеси та їх учасники в іспаномовній культурі.

Перспективними напрямками подальшого дослідження $\epsilon$ порівняльний лінгвістичний аналіз використання метафори, зокрема морбіальної, в українських та іспанських медійних текстах економічної тематики, а також дослідження метафоричної профілізації економічних концептів та порівняння лінгвістичних засобів ії втілення в іспанській та українській мовах. 


\section{Література:}

1. Евтушина, Т., Ковальская, Н. «Экономический дискурс как объект лингвистического исследования.» Вестник Челябинского гос. университета 6 (335), Серія «Филология. Искусствоведение» 88 (2014): 42-46.

2. Лакофф, Дж., Джонсон, М. «Метафоры, которыми мы живем.» Теория метафоры (1990): 387-415.

3. Петушинская, Е. Г. «Язык популярного экономического дискурса.» Автореф. дисс. канд. филол. наук, Москва, 2008.

4. Ульманн, С. «Семантические универсалии.» Новое в лингвистике, вып. 5: Языковые универсалии (1970), 301.

5. Чудинов, А. П. «Россия в метафорическом зеркале: когнитивное исследование политической метафоры (1991-2000).» Монография (Екатеринбург, Урал. гос. пед. ун-т, 2001), 238.

6. Spencer, Alice. «Las metáforas de la salud en un corpus de la crisis financiera alemánespañol.» CVC. E-Aesla. Revista digital de lingüística aplicada, No. 1: Lingüística de corpus, computacional e ingeniería lingüística (2015), доступ cvc.cervantes.es/lengua/ eaesla

\section{References:}

1. Evtushina, T., Kovalskaya, N. «Ekonomicheskiy diskurs kak ob'ekt lingvisticheskogo issledovaniya [Economic discourse as an object of linguistic research].»Vestnik Chelyabinskogo gos. Universiteta 6 (335), Seriya «Filologiya. Iskusstvovedenie» 88 (2014), 42 (In Rus).

2. Lakoff, G., Johnson, M. «Metafory, kotorymi my zhivem [Metaphors We Live By].» Teoriya metafory (1990): 387-415 (In Rus).

3. Petushinskaya, E. G. «Yazyk populyarnogo ekonomicheskogo diskursa [Language of the popular economic discourse].» Avtoref. diss. kand. filol. nauk, Moskva, 2008 (In Rus).

4. Ulmann, S. «Semanticheskie universalii [Semantic universals].» Novoe v lingvistike, Vol. 5: Yazyikovyie universalii (1970), 301 (In Rus).

5. Chudinov, A. P. Rossiya v metaforicheskom zerkale: kognitivnoe issledovanie politicheskoy metaforyi [Russia in the metaphorical mirror:cognitive study of political metaphor] (Ekaterinburg, 2001), 238 (In Rus).

6. Spencer, Alice. «Las metáforas de la salud en un corpus de la crisis financiera alemánespañol [The metaphors of health in a corpus of the German-Spanish financial crisis].» CVC. E-Aesla. Revista digital de lingüística aplicada, No. 1: Lingüística de corpus, computacional e ingeniería lingüística (2015), access mode cvc.cervantes.es/lengua/ eaesla (In Spanish). 


\title{
СТАТИКА І ДИНАМІКА МОВИ: ПРОБЛЕМИ РІВНОВАГИ
}

\author{
Гриценко Світлана Павлівна, ap730518@gmail.com \\ д. філол. наук, доцент \\ Київський національний університет імені Тараса Шевченка, \\ Інститут філології
}

У статті на підставі українськомовних писемних пам'яток різних стилів $i$ жанрів проаналізовано лексикон украӥнської мови XVI-XVII cm. як системний динамічний феномен, запропоновано низку нових підходів до аналізу динаміки лексики в часі. Виявлено фактори розвитку лексикону української мови; встановлено закономірності вербалізаиії позамовної сфери в окреслений період історії мови. Розкрито прояви динаміки і статики в лексищі украйнської мови XI-XV cm. та XVI-XVII ст., схарактеризовано комбінаторику різних змін лексичної системи украӥнської мови. 3'ясовано закономірності розширення українського лексикону завдяки деривацї та іншомовним впливам, зміни архітектоніки лексичної системи та ї̈ конщептуальної організації як форм відтворення тогочасної мовної картини світу українців. Досліджена формальна та семантична деривація номінативних одиниць, адаптачія запозичень до структури мови-реципієнта. Звернута увага на потребі верифікаиії часу та умов появи в украӥнській мові багатьох лексем.

Ключові слова: динаміка, статика, взаємодія мов, лексикон, питома лексема, запозичення, мова-джерело, мова-рещипієнт, мова-посередниия, адаптаџія, дериваџія, хронологія запозичування.

\section{СТАТИКА И ДИНАМИКА ЯЗЫКА: ПРОБЛЕМЫ РАВНОВЕСИЯ}

\section{Гриценко Светлана Павловна, ap730518@gmail.com}

д. филол. наук, доцент

Киевский национальный университет имени Тараса Шевченко

Институт филологии

В статье на основе украиноязычных письменных источников различных стилей и жанров исследован лексикон украинского языка XVI-XVII вв. как системный динамический феномен, предложены новые подходы к анализу динамики лексики во 
времени. Определены факторы развития лексикона украинского языка и установлены закономерности вербализачии внеязыковой сферы в исследуемый период. Продемонстрировано соотношение динамики и статики в лексике украинского языка XI-XV вв. и XVI-XVII вв., дана характеристика комбинаторике различных изменений лексической системь украинского языка. Изучень закономерности расширения лексикона украинского языка как следствия иноязычного влияния и деривации, архитектоника лексической системь и ее концептуальная организация как формь отражения языковой картины мира украинцев XVI-XVII вв. Проанализирована формальная и семантическая деривация номинативных единии, адаптация заимствований $к$ структуре языка-реципиента. Актуализировано внимание на необходимости верификаџии времени и условий появления многих лексем в украинском языке.

Ключевье слова: динамика, статика, взаимодействие языков, лексикон, исконная лексема, заимствование, язык-источник, язык-реципиент, язык-посредник, адаптащия, деривачия, хронология заимствования.

\section{STATICS AND DYNAMICS OF THE LANGUAGE: THE ISSUE OF BALANCE \\ SvitlanaGritsenko, ap730518@gmail.com \\ Doctor of Philology \\ Kyiv National Taras Shevchenko University \\ Institute of Philology}

The vocabulary of the Ukrainian language of the XVIth-XVIIth century as a systemic dynamic phenomenon was studied in the thesis basing on Ukrainian-language written sources of various styles and genres, a set of techniques was selected and applied, a number of new approaches to the analysis of the time dynamics of vocabulary was proposed.

It is stressed that the most noticeable are changes of vocabulary and semantics due to the verbalization of the dynamics of the culture of society - the transformations in the material-subject and production spheres, intercessions of some social and cultural dominants. It is accentuated that an important factor in the dynamics of the Ukrainian language is its interaction with the other languages, that leads to the changes in the structure of language elements, their interconnections and their functions.

The correlation between dynamics and statics in the vocabulary of the Ukrainian language of the XIth-XVth century and XVIth-XVIIth century is determined, combinations of various changes of the lexical system of the Ukrainian language are characterised. Changes appear in the formation of new values of specific or borrowed lexemes as a result of metonymic transformations, semantic attraction, entering into constant phrases or cliché expressions, generalization or specialization of meanings, emergence of connotative, 
estimative elements of semantics. Functional reduction of the word, its absence in the written sources of the next period in comparison with the previous stage of the existence in language testifies deactualization of the notion in the language model of the world, as well as intercession of an older lexeme by a new nomination - specific or borrowed. The regularities of the expansion of the Ukrainian vocabulary due to foreign-language influences are discovered, the factors that influenced the degree of saturation of thematic and lexicalsemantic groups are outlined. The architectonics of the lexical system and its conceptual organization as a reproduction of the contemporary language model of the world of Ukrainian people are revealed.

The formal and semantic derivation of nominative units, adaptation of borrowings to the structure of the recipient language are analized. Dynamics of the formal structure of the vocabulary is connected with a change in the meaning of the primary lexeme. Formal derivation establishes motivational and word-formation models, outlines productive ones for the appropriate period of language development. According to the sources of the XVIth$X V I I t h$ century both non-hybrid (monolingual) and hybrid derivatives are present there.

Analysis of derivatives of foreign genesis, the history of their appearance in the Ukrainian language of the XVIth-XVIIth century, as well as the study of the functioning of borrowings in the language allowed to estimate hypothetically the place of derivation (in the source language, intermediate language, recipient language); complexity of genesis estimation of derivatives associated with the presence of common affixes and word-formation models for interacting languages.

For many lexemes the time of their appearance in the Ukrainian language is specified, assumptions about time and conditions of borrowings are verified. For the study of the history of borrowings it is important to find out the history of functioning of the corresponding lexemes in the source language and intermediate languages, and their timing appearance (moment of entry), distribution and adaptation in the recipient language. Determination of the moment, the time of , birth” - appearance and rooting - of the borrowings foresees the proof of the absence of written fixation of an appropriate lexeme in older written sources. The conditional identification of the time of the first fixation and the time of borrowing allowed to find out lexemes for which the time of borrowing can be set: for such date a year / relative chronological sign, which is indicated in the written source, or exactly the year of writing a memorial are accepted. For a series of lexemes relative chronological characteristics (indication of time period from the interval of one year to another or the corresponding century) are proposed. Application of methods of determining the time of the appearance of lexeme based on the history of the designated reality contributed to the definition of borrowings that nominate the notion of material culture, the history of which is clearly established, or the time before which these borrowings could not appear in the recipient language. 
It was clarified that the chronology of foreign language nominatives contributes to clarification of the sources of borrowing, in particular, for alternative explanations available in science. An important role in determining the chronological characteristics of the lexemes has the information about the peculiarities of the analyzed lexemes' functionning in the potential intermediary languages.

Key words: dynamic, static, interaction of languages, vocabulary, specific lexeme, borrowing, source language, recipient language, intermediary language, adaptation, derivation, chronology of borrowings.

Осмислення української мови в діахронії передбачає вивчення елементів усіх іiі структурних рівнів на різних часових зрізах, зіставлення стану мови, змінності чи статики кожного іiі компонента. Зрозуміло, що охопити усіх без винятку елементів не може один дослідник, як і $\epsilon$ самоочевидним, що на такий крок уповажнюють наявні джерела інформації. Адже пам'ятки за всього їхнього позірного багатства відтворюють мову вибірково. I ця вибірковість заважає реалізувати ідеальну модель дослідження, змушує рахуватися з реаліями, на підставі яких вибудовується гносеологічна модель руху мови на осі часу.

Основою вивчення історичних змін мови є писемні пам'ятки, укладені на основі картотеки, текстофонди; важливим джерелом залишаються численні студії наших попередників, їхні часто прозірливі оцінки, міркування, висновки 3 докладного аналізу, зокрема це праці О. О. Потебні, П. Г. Житецького, С. Смаль-Стоцького, В. Сімовича, А. О. Білецького, Є. К. Тимченка, I. І. Огієнка, П. П. Плюща, Ю. В. Шевельова, В. М. Русанівського, С. В. Семчинського, І. П. Чепіги, Л. П. Гнатюк, О. І. Ніки, Г. М. Наєнко, В. М. Мойсієнка та ін. Усе це є підставою для нових дослідницьких спроб, спрямованих на розуміння моделей розвитку української мови.

Лексику вважають особливо динамічним структурним рівнем, що пов'язаний із відтворенням мовної картини світу в їі динаміці, зокрема змін в економічному, культурному житті суспільства, різновекторних зв'язків між народами.

В історії розвитку української мови період XVI-XVII ст. - час бурхливих політичних, економічних, культурних, мовних трансформацій. Це складний період усвідомлення необхідності відродження „української еліти” на тлі національного ренегатства, коли українські великопанські роди або вимерли, або стали католицькими; коли, за вдалими оцінками дослідників, 
„українець із вищих соціальних верств нагадував порожню посудину, у яку стороння сила, спираючись на насильство, вливала свій - у кожен раз новий зміст: перефарбовувала українця то в поляка, то в австрійця, то в росіянина" [Лісовий 1997, с. 225]. XVI-XVII ст. - це період бурхливого розвитку освіти, книгодрукування на тлі мовного протистояння за сфери функціонування, а відтак і статусність мов.

Активізація суспільного життя XVI-XVII ст. спонукала створення значної кількості писемних текстів, частина 3 яких зберіглася сьогодні i становить Золотий фонд інформації про історію нашої мови. Одним із визначальних завдань сучасної україністики і славістики $є$ вивчення цих пам'яток, їх докладний опис, на чому наголошував В. М. Топоров: „Самодостатність і іманентність мови роблять зайвим питання про сенс і мету опису мовних елементів. Сенс і мета - в самому описі ..., тому їх потрібно шукати в самій мові" [Топоров 1995, с. 7].

Обираючи об'єктом вивчення динаміку в часі лексики як структурного рівня мови, свідомі існування нерозривного зв'язку між змінністю лексикону і того інформаційного поля, у якому перебували тогочасні українці. Поява великої кількості нових номінативних засобів часто сигналізувала про виформування, входження нових понять, і відповідно була свідченням зацікавлення різними сферами економічного, суспільного життя, міжособистісними взаєминами. Багато із понять, явищ, реалій належать до кола статичних, відомих упродовж тривалого часу (як скажімо, торгівля, обмін, предмети зі сфери виробництва, трудових процесів, тощо). Але водночас з'являлося багато нових елементів матеріальної культури, типів економічних, суспільних відношень, які або вже приходили в українськомовне середовище 3 готовими номінаціями, або ж для них формувалися нові вербальні позначення. Нерідко цей процес мав ще один важливий складник - перебудову, часткову чи відчутну зміну в обсягах значень, використанні уже наявних елементів лексикону. Наприклад, відома ще за пам'ятками XI-XIII ст. лексема мыто“торгове мито' (,И да входлтъ в городъ Фдіными вороты съ царевымъ мужьмъ безъ юружьћ, ... и да творАт куплю, њко же имъ надобь, не платАче мыта ни в чемь же” 907 р. [Договоръвел. кн. Олега сь Греками по Ипат. списку „Повьстиврем. льть” // ИЛ, 595 стб.]) у XIV-XV ст. розширює своє значення до 'митна застава', 'митниця'; у XVI ст. у цьому значенні приймає синонімічні позначення комора і комора мытная; а в XVII ст. додає трансформовані 
означення мытницкая / мытничая і водночас лексема мыто розвиває ще одне значення 'плата, винагорода, заохочення’ (див. Таблиця 1).

Таблиияя 1. Лексема мыто у пам'ятках XIV-XVII ст.

\begin{tabular}{|c|c|c|c|}
\hline & 'торгове мито' & 'митна застава, митниця' & $\begin{array}{c}\text { 'плата, } \\
\text { винагорода, } \\
\text { заохочення' }\end{array}$ \\
\hline XIV ct. & \begin{tabular}{l}
\multicolumn{2}{c}{ мыто } \\
„А мыта нє примышлАти \\
но какь из вБка пошло” 1366 \\
р. [Українські грамоти XIV \\
ст. // Розов, 14]; \\
„A jestliby kotoryje reczi \\
kramnyje wez, majet myto \\
płatiti” 1389 p. [Zbiór praw \\
litewskich od roku 1389 do \\
roku 1529 // ZPL, 105]
\end{tabular} & 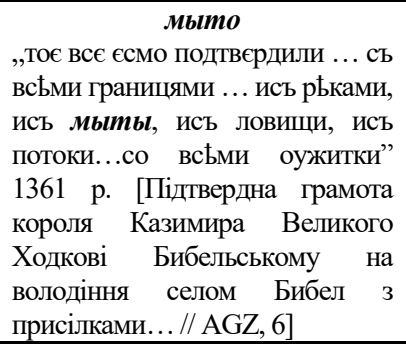 & \\
\hline XV ст. & 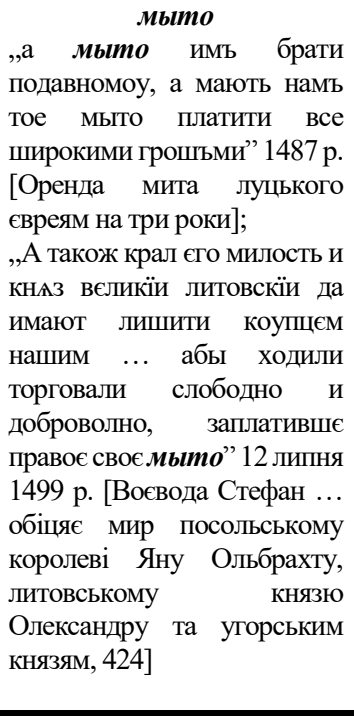 & 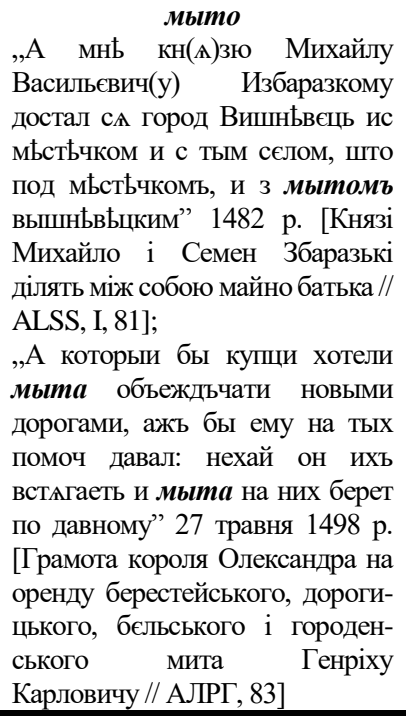 & \\
\hline XVI ст. & 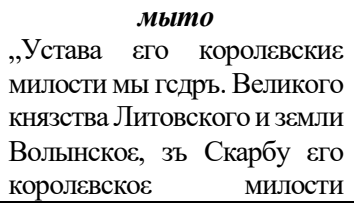 & \begin{tabular}{l}
\multicolumn{1}{c}{ мытница } \\
„онъ сьдить на мытмицц” \\
1556-1561 рр. [Пересопницьке \\
євангеліє // ПЄ, 35]
\end{tabular} & \\
\hline
\end{tabular}




\begin{tabular}{|c|c|c|c|}
\hline & 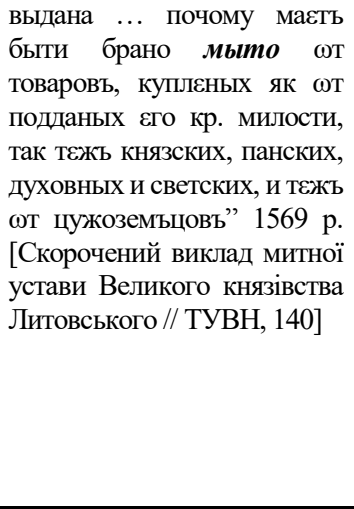 & 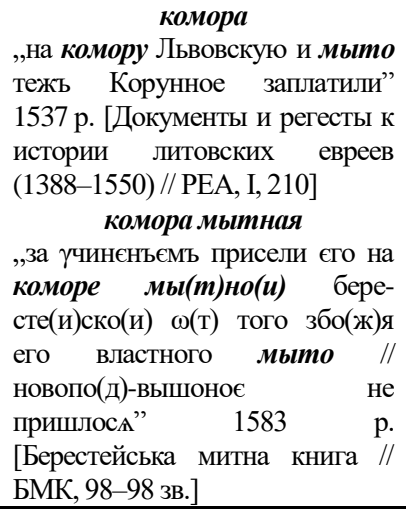 & \\
\hline XVII ст. & 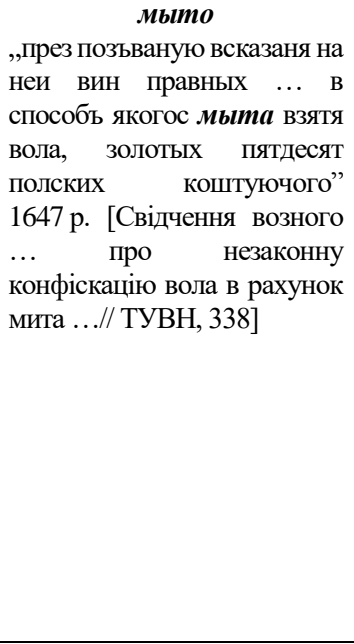 & 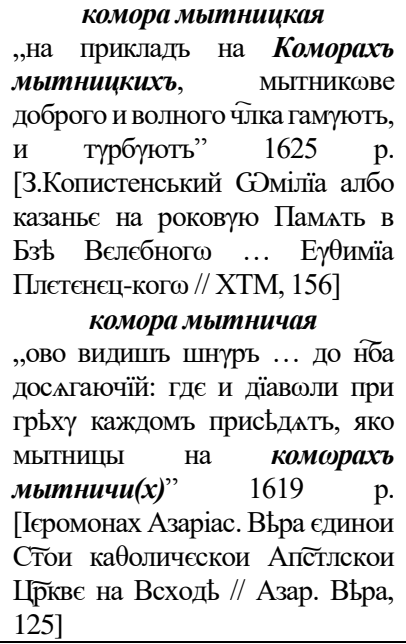 & \begin{tabular}{l}
\multicolumn{1}{c}{ мыто } \\
„Слуга \\
мыто $\quad$ свое \\
заслужоное \\
возоветь ко \\
Господу” \\
1656 р. [Руко- \\
писный хро- \\
нограф, 62]
\end{tabular} \\
\hline
\end{tabular}

Здатність адаптувати, а не лише прийняти іншомовні елементи до системи мови-реципієнта, розширити засоби за умови збереження і власних ресурсів - свідчить про силу української мови. Результатом цього процесу $\epsilon$ фіксовані у писемних джерелах дублети, синоніми (див. Таблиця 2).

Таблиия 2.Питомі та запозичені агентиви XVI-XVII ст.

\begin{tabular}{|l||l|l|}
\hline \multicolumn{1}{|c||}{ Значення } & \multicolumn{1}{|c|}{ Питома лексема } & \multicolumn{1}{|c|}{ Запозичена лексема } \\
\hline \hline \multirow{2}{*}{ 'астролог' } & гвіздар / звъздаръ & астроліогъ(XVII ст.) \\
\cline { 2 - 3 } & въщциъ & практикаръ(XVII ст.) \\
\hline
\end{tabular}

Actual Problems of Linguistics $\overline{\text { [Aktual'niproblemymovoznavstva] }}$ (C) Gritsenko S.[Grycenko S.], ap730518@gmail.com Statics and Dynamics of the Language: the Issue of Balance [Statyka i dynamika movy: problemy rivnovagy] (in Ukrainian) 
STUDIA LINGUISTICA, 2018. - Вип. 13: 48-70

\begin{tabular}{|c|c|c|}
\hline & въщчокъ & \\
\hline & звбздословъ & \\
\hline 'астроном' & звбздозаконникъ & астрономь (1598 р.) \\
\hline \multirow{2}{*}{$\begin{array}{l}\text { 'людина, яка живе } 3 \\
\text { милостині, жебракує; той, } \\
\text { хто випрошує' }\end{array}$} & прошак & жебракъ(1598 р.) \\
\hline & въчнийстарець & ковдошъ (XVI ст.) \\
\hline 'вигнанець' & вигнанець & банить(1597 р.) \\
\hline ‘той, хто вибиває вовну’ & волняръ & $\begin{array}{l}\text { шаповаль (кін. XVII - поч. } \\
\text { XVIII ст.) }\end{array}$ \\
\hline 'палітурник' & льпитєль & интрельтаторь (1612р.) \\
\hline \multirow{12}{*}{$\begin{array}{l}\text { ‘грабіжник, порушник, } \\
\text { розбійник, негідник’ }\end{array}$} & грабитель & лотрь(1528 р.) \\
\hline & грабовникъ & выдирияа(п. XVII ст.) \\
\hline & рабовникъ & выдырарачъ(XVIII ст.) \\
\hline & злодюга & опричникъ(1621 р.) \\
\hline & воропай & збойцุа $(1509$ р.) \\
\hline & нарушитель & драпьжникъ(1592 р.) \\
\hline & & драпьжияа(1556-1561 рр.) \\
\hline & & драпьжливый(1637р.) \\
\hline & & лупьжияа (1599 р.) <псл. \\
\hline & & коррупторь (1639р.) \\
\hline & & виоляторь (1638 р.) \\
\hline & & ексъиесоръ(1634 р.) \\
\hline
\end{tabular}

Для виявлення i розуміння характеру змін українського лексикону у XVI-XVII ст. необхідно враховувати і попередній період староукраїнської писемності: від княжої доби XI-XIII ст. через період післямонгольської навали XIV-XV ст. аж до періоду досліджуваного XVI-XVII ст. Якщо оглянути репертуар лексикону XVI-XVII ст. на тлі зазначених двох попередніх періодів, то картина виглядає так: одні лексеми засвідчують тяглість упродовж трьох періодів, інші - від другого і в третьому періоді, ще інші - лакунарність у XIV-XV ст., i нарешті - багато лексем зафіксовано лише у XVI-XVII ст. Таблиця 3 демонструє активне поповнення іншомовними елементами ТГЛ освіта i наука у досліджуваний період, що було типовим і для інших ТГЛ.

\section{Таблицяя 3.Динаміка складу ТГЛ освіта і наука за джерелами XI-XVII ст.}

\begin{tabular}{|l||c||c|c|c|}
\hline \multirow{2}{*}{ Запозичення } & \multicolumn{1}{|c||}{ Значення } & \multicolumn{3}{|c|}{ Писемні джерела } \\
\cline { 3 - 5 } & & $\begin{array}{c}X I-X I I I \\
\mathrm{~cm} .\end{array}$ & $\begin{array}{c}X I V-X V \\
\mathrm{~cm} .\end{array}$ & $\begin{array}{c}X V I-X V I I \\
\mathrm{~cm} .\end{array}$ \\
\hline \hline азъбукьл & 'алфавіт' & + & & + \\
\hline
\end{tabular}

Актуальні проблеми мовознавства [Актуальные проблемы языкознания] (С Гриценко С. П. [Гриценко С. П.], ap730518@gmail.com Статика і динаміка мови: проблеми рівноваги [Статика и динамика языка: проблемы равновесия] 
STUDIA LINGUISTICA, 2018. - Vol. 13: 48-70

\begin{tabular}{|c|c|c|c|c|}
\hline грамота & $\begin{array}{l}\text { 'писемність', ‘напис', 'письмо’ } \\
\text { 'лист’, 'грамота, діловий } \\
\text { документ' }\end{array}$ & + & + & + \\
\hline юпистольһы & 'лист, послання’ & + & & + \\
\hline ярльккъ & 'грамота татарського хана' & + & & + \\
\hline харатьна & 'пергамент' & + & + & + \\
\hline хронографь & 'літописець, хроніст’ & + & & + \\
\hline граматикина & ‘граматика’ & + & & + \\
\hline $\begin{array}{l}\text { астрономињ, } \\
\text { острономьца }\end{array}$ & $\begin{array}{l}\text { 'астрономія, } \text { наука } \\
\text { небесні тіла' }\end{array}$ & + & + & + \\
\hline кондакъ & $\begin{array}{l}\text { 'хвалебна пісня церковного } \\
\text { змісту, кондак' }\end{array}$ & + & + & + \\
\hline кондакаръ & $\begin{array}{l}\text { 'збірник церковних пісень, } \\
\text { кондаків' }\end{array}$ & + & & + \\
\hline дидаскалия & ‘церковна школа, дидаскалія’ & & + & \\
\hline \multirow[t]{5}{*}{ икола } & $\begin{array}{l}\text { 'послідовники христи- } \\
\text { янського вчення' }\end{array}$ & & & + \\
\hline & ‘система освіти’ & & & + \\
\hline & 'суспільна думка' & & & + \\
\hline & 'колектив учнів’ & & & + \\
\hline & \multirow[t]{4}{*}{ 'навчальний заклад’ } & & + & + \\
\hline икулка & & & & + \\
\hline школка & & & & + \\
\hline иколньидом & & & & + \\
\hline $\begin{array}{l}\text { школяр / } \\
\text { школярей, } \\
\text { школьник }\end{array}$ & \multirow[t]{2}{*}{ ‘особа, яка навчається’ } & & & + \\
\hline схоластик & & & & + \\
\hline иколярський & ‘належний школяру’ & & & + \\
\hline хартофилакъ & 'бібліотекар, хранитель книг’ & & + & + \\
\hline nараграфь & ‘розділ’ & & & + \\
\hline шпаргаль & $\begin{array}{l}\text { 'старий списаний папірець } 3 \\
\text { потрібною інформацією’ }\end{array}$ & & & + \\
\hline лекція & $\begin{array}{l}\text { 'усний виклад відпо-відного } \\
\text { предмета' }\end{array}$ & & & + \\
\hline акростіхісь & 'акровірш' & & & + \\
\hline инкаусть & 'чорнило' & & & + \\
\hline секстернъ & 'зошит' & & & + \\
\hline твичине & 'навчання' & & & + \\
\hline
\end{tabular}

Actual Problems of Linguistics $\overline{\text { [Aktual'niproblemymovoznavstva] }}$

(C) Gritsenko S.[Grycenko S.], ap730518@gmail.com

Statics and Dynamics of the Language: the Issue of Balance [Statyka i dynamika movy: problemy 
STUDIA LINGUISTICA, 2018. - Вй. 13: 48-70

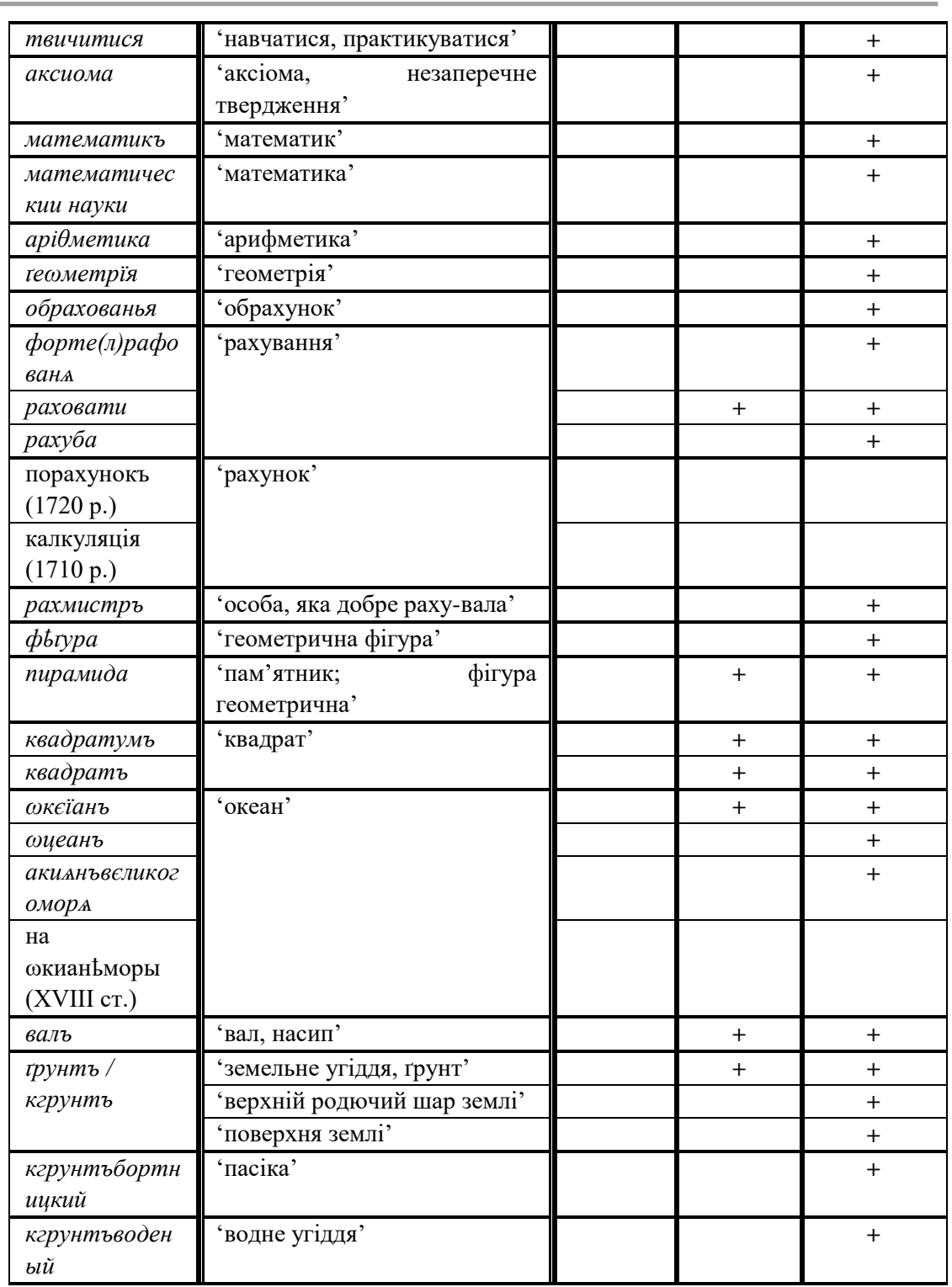


STUDIA LINGUISTICA, 2018. - Vol. 13: 48-70

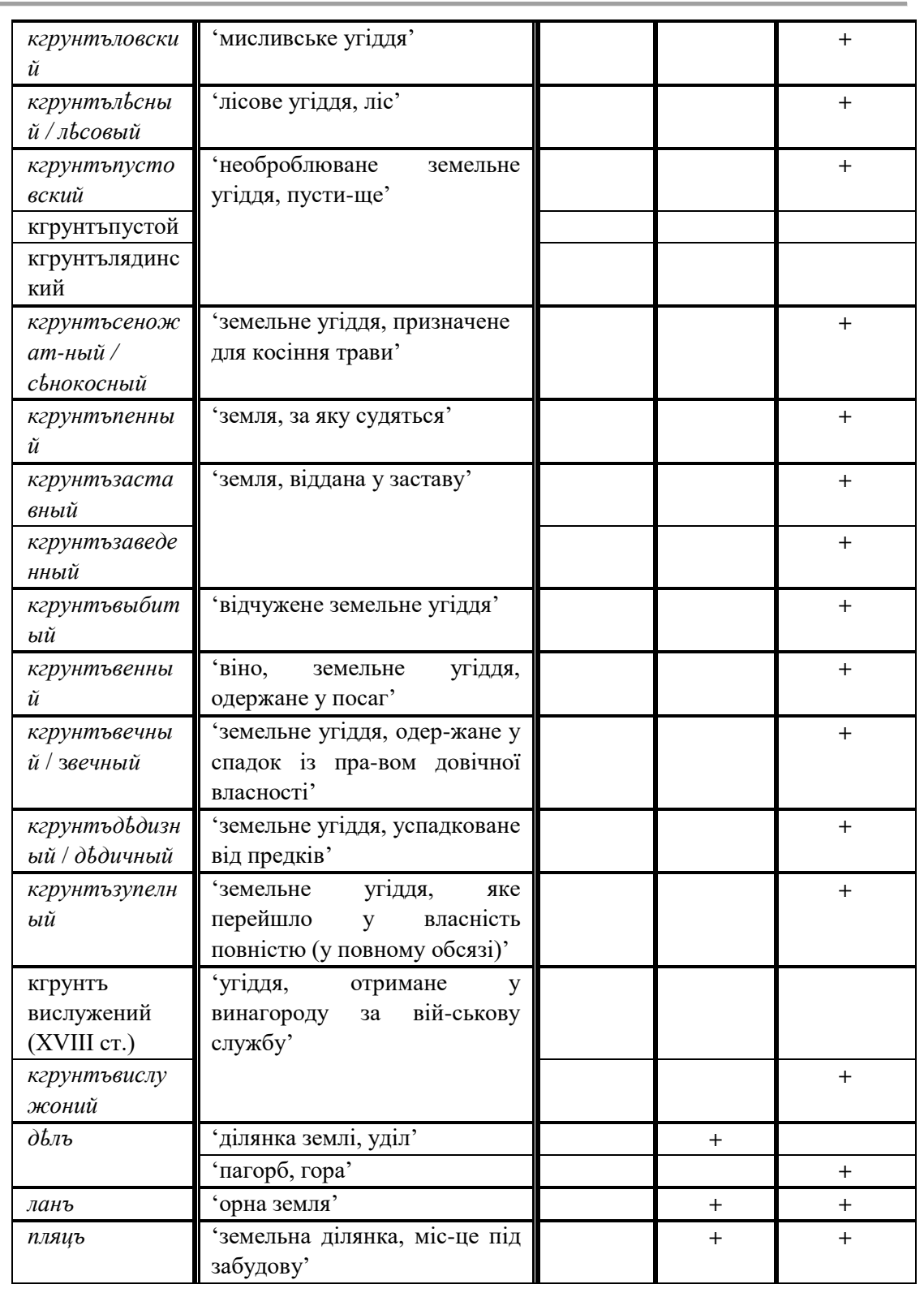

Actual Problems of Linguistics $\overline{\text { [Aktual'niproblemymovoznavstva] }}$

(C) Gritsenko S.[Grycenko S.], ap730518@gmail.com Statics and Dynamics of the Language: the Issue of Balance [Statyka i dynamika movy: problemy rivnovagy] (in Ukrainian) 
STUDIA LINGUISTICA, 2018. - ВиI. 13: 48-70

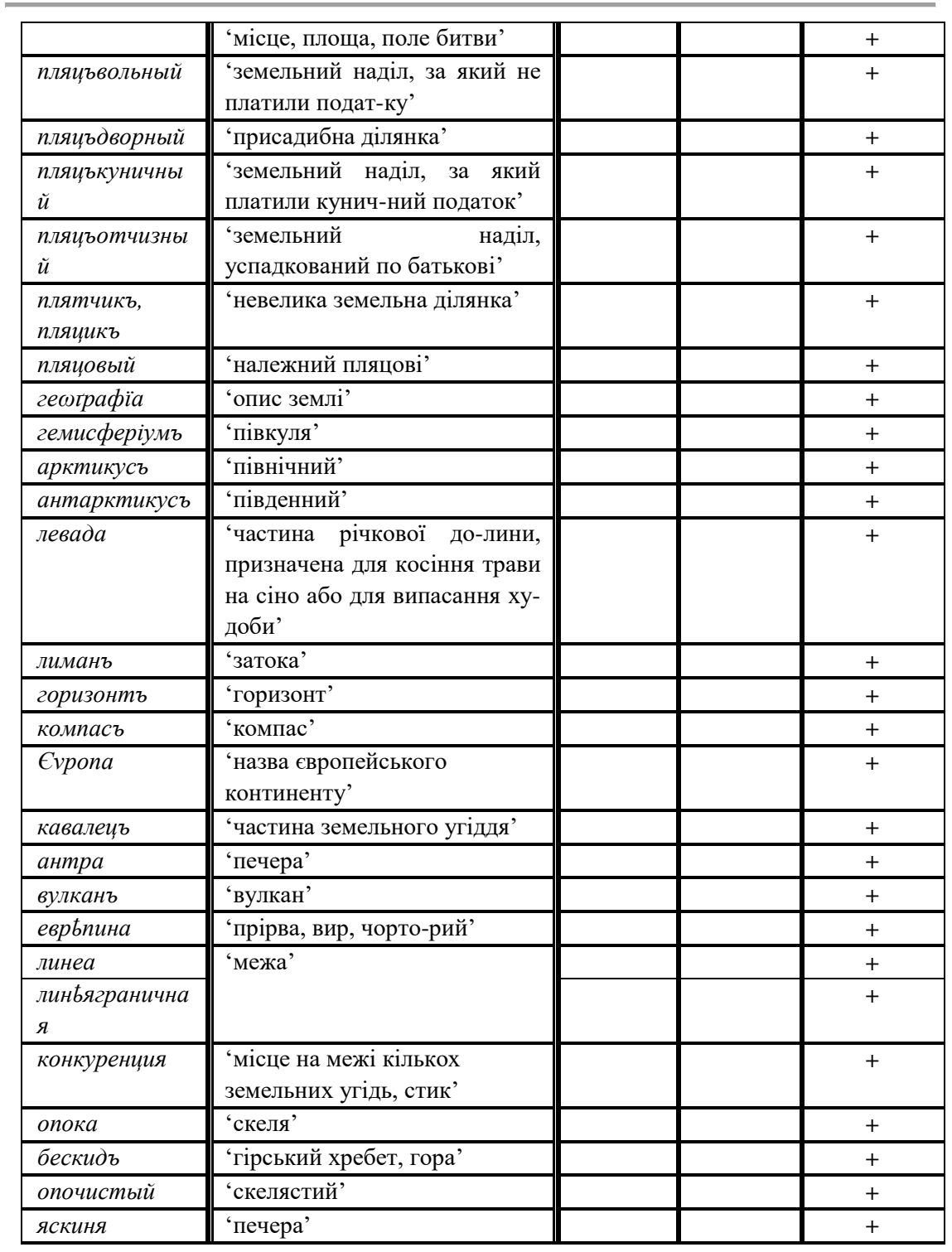


STUDIA LINGUISTICA, 2018. - Vol. 13: 48-70

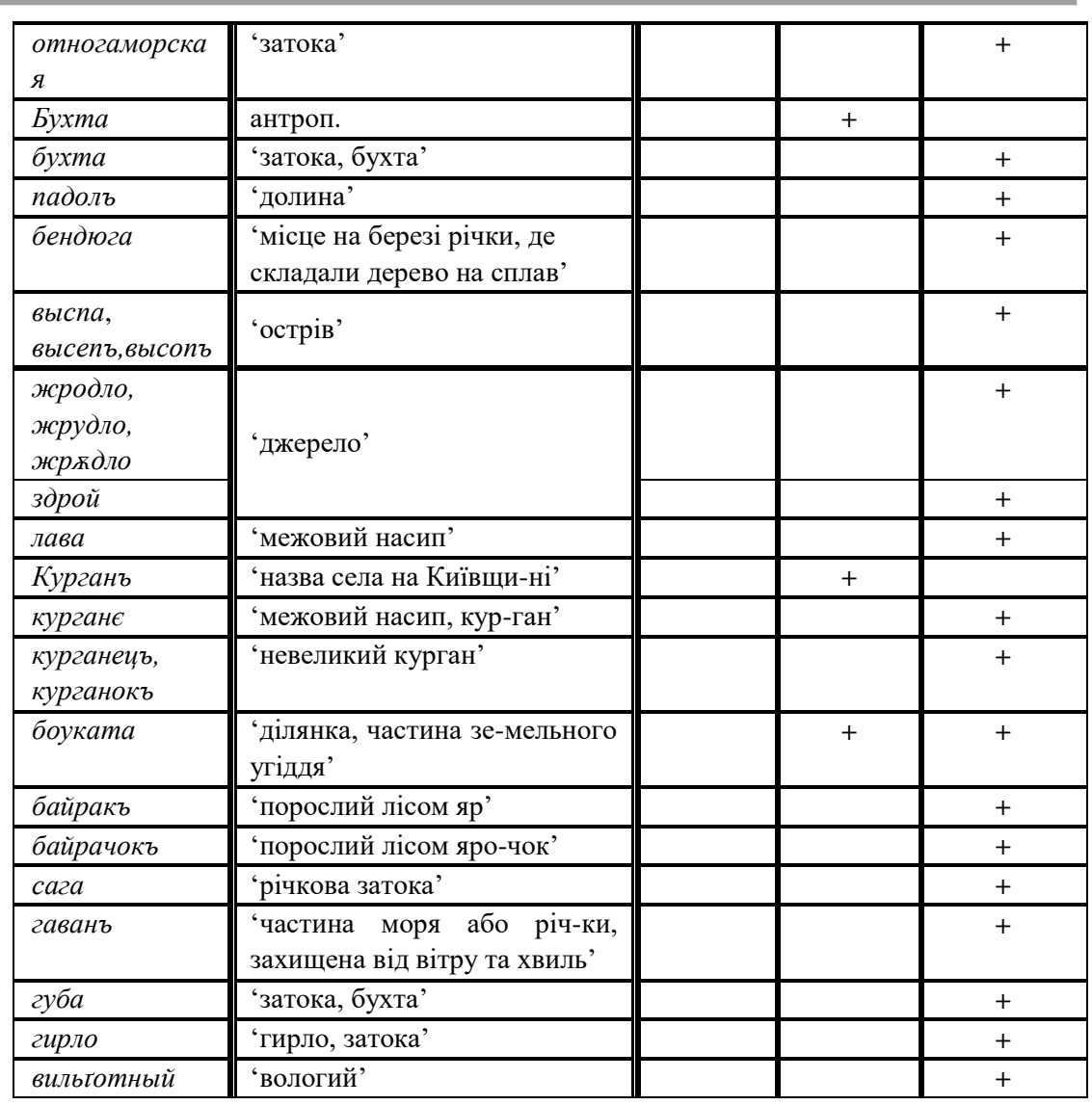

Таблиця 3 демонструє лише спецчифіку відтворення питомих i запозичених лексем українськими писемними пам'ятками XVI-XVII ст.; ми не можемо стверджувати, що якогось слова не було в усному мовленні українців.

За спостереженнями, співвідношення реєстрів лексем, відтворених у пам'ятках, виглядає так: лексем, які пройшли від XI до XVII ст. 21 одиниця; лексем, які мали лакуни - 47; лексем, що не засвідчені джерелами досліджуваного періоду, хоча відомі у попередні - 50; лексем, що зафіксовані у пам'ятках з XIV ст. і включно до XVII ст. - 263; лексем, 
писемне функціонування яких виявлено лише у XVI-XVII ст. - 2362. Ми свідомі релятивності цих висновків, але не можна заперечити загальної тенденції збільшення кількості пам'яток, а відтак і представлених лексем.

Ідучи шляхом виокремлення і часової параметризації лексики, ми розуміємо, що рівень похибки може бути доволі відчутним. Адже дослідження етапів формування лексикону у віддалені епохи має свою специфіку: воно має обмежений лише писемними текстами ресурс інформації, який часто засвідчує факт лакунарності представлення мовного елемента. Поняття лакунарність розуміємо як непослідовне в часі, вибіркове відбиття багатьох лексем. Зокрема маємо багато фактів, коли лексема була засвідчена пам'ятками давніше, далі спостерігаємо тривалий проміжок відсутності фіксації і їі появу після часової перерви. Так, лексема икономъ відома $з$ пам'яток поч. XII ст., а на поч. XVII ст. фіксується слово економъ, так само: үксүсъ 1136 р. - сер. XVII ст.; мынцарь 1388 р. - 1500 р.; барханъ 1392 р. - 1564 р.; чета 1499 р. - чата 1633 р. та ін. Лакунарність $\epsilon$ зрозумілою; вона могла бути зумовлена маловживаністю запозичень у хронологічно віддалений період, що спричинило їх тривале невідтворення в пам'ятках і відродження (а можливо, і повторне запозичення) пізніше, зокрема в досліджуваний період. У своїх твердженнях використовуємо модальність допустовості, оскільки чітко вказати, що процес був таким i тільки таким за відсутності для окремих періодів в історії мови надійних джерел не можна; тому висловлюємо припущення, що і за умов вказаної лакунарності тяглість зберігалася.

Вивчення розвитку лексики мови в часово віддалені періоди залишає, на жаль, відкритим питання ролі усної комунікації в запозичуванні, оскільки письмо, як зауважив Ф. де Соссюр, приховує мову від наших очей; важко вичерпно окреслити роль писаря, його ідіолектну, а часто й мовноетнічну належність, оскільки ні писемні пам'ятки, ні інші джерела такої інформації не дають.

Дослідження пам'яток XVI-XVII ст. на тлі попередніх епох дають підстави констатувати, що частина лексики, що була відома в XI-XV ст., уже не засвідчена у пізніших пам'ятках, що уможливлює припущення про їх деактуалізацію в мовленні, функційну редукцію. Це явище за особливостями протікання та наслідками було неоднорідним. Зокрема:

- втрата церковнослов’янізма грецького походження сынъклить на 
позначення 'ради старійшин' („Тыевси села, отънасъ ку церкви Божой прыданые, маетъ держати господинъ богомолецъ нашъ Климентый ... а за насъ и чада наша Господа Бога молити и о добромъ посполитомъ, вкупе зъ сынъклитомъ нашимъ ... радити" 1322 р. [АрхЮЗР, Ч. 1, т. 6, 3]); запозичення з німецької мови боургоурь / боургарь 'міський радник’(,прїидєкъ г(с)во ми посо(л) о(т) брашєва ... на имА па(н) де(к) хано(с) и па(н) боургоуръмихи(л) и просили оу г(с)ва ми миръ и мыто" 1437 p. [Cost, II, 709], „а ли(ст) єсми дали бръгароу михаєви” 1437 р. [ССУМ I, 131]); з угорської - вигъ 'сувій, міра довжини тканини' (,алє полотно и бобовълоктємъ не продаю(т), а соукнасъ вигомъ да продаю(т)" 1449 p. [Cost, II, 743]) та ін;

- в окремих випадках простежуємо трансформацію значення, зокрема латинізм цата / ц̧Ата в XI ст. позначав 'дрібну монету, гріш', а також збірне поняття 'гроші'; у XVI ст. ця лексема втрачає значення 'гроші'. Церковнослов'янізм рать засвідчений у писемних джерелах X-XIII ст. на позначення понять 'військо', 'ворог', 'війна', 'битва, бій', 'ворожнеча'; у писемних пам'ятках XIV-XV ст. ця лексема зафіксована зі значенням 'військо'; у XVI-XVII ст. слово рать витісняється питомою лексемою воиско і латинізмом армата на позначення поняття 'військо' (,ге(т)ма(н) ... ро(с)казаль ... воискуа бы за Дньпръ на лежү пошли на зиму” сер. XVII ст. [Львівський літопис, 174] чи „Гетманъ запорозскийзъ гарматою стануль въ ББлой Церкви” 1630 р. [МИВР, 302]); на позначення 'ворог', 'війна', ‘битва, бій', ‘ворожнеча' у писемних джерелах досліджуваного періоду це слово не засвідчене, однак чітко окреслюється нове значення - ‘боротьба внутрішня, душевна' („И зась на дрүгомъ мьстц бжїа поглашаєть любовъ родителей. А хто бы повьда(л) в(ъ) собь шбою имБти, себе прельстилъ, слышалъ мовАчого. нє прійдохъ вложити покою на землю, але рать" [Отп. КО, 14]). Нагадаємо, що окремі давні значення збереглися в українській мові XIX-XX ст.: лексема рать використовується на позначення 'великої кількості кого- чи чого-небудь однорідного’, що демонструє поезія „Дві сили” Максима Рильського:

„О кодло підле і несите,

Дурисвітів злостива рать!

Чи правду нашу вам убити? 
Чи наше братство розбратать?"

(М. Рильський, II, 1960, с. 318)

Може вживатися ця лексема і з іншим значенням: як урочисте 'битва', зокрема: у романі Семена Скляренка „Святослав”: „Коли на Дніпрі чи в степу з'являвся ворог, водили [старійшини] людей на рать" (Скл., Святослав, 1959, 12). Також лексема рать у сучасній українській мові $\epsilon$ вершиною дериваційного гнізда: ратний 'призначений для раті', ‘бойовий, воєнний’ та ратник ‘боєць раті, воїн' [СУМ, 8, 454]. Ці приклади ще раз переконують у тому, що мова - це живий організм, що постійно видозмінюється;

- в окремих випадках маємо появу формально ускладненого елемента, зокрема тюркізм єсакъ у кінці XV ст. позначав 'податок натурою', а пам’ятка XVI ст., а саме „Опис Чорнобильського замку” (1552р.) фіксує форму єсачъчизна.

Спостережено також випадки втрати у досліджуваний період однієї iз раніше відомих трансформ, зокрема запозичення 3 давньоверхньонімецької мови пискупъ ‘єпископ' засвідчене в писемних джерелах II пол. XIV ст. і вживалося одночасно з формою бискупь, відомою 3 I пол. XIV ст. Форма бискупъ продовжила своє функціонування у мові XV-XVII ст., на відміну від форми пискупъ та іiї дериватів пискоупъство, пискоупъскии, які були втрачені.

Аналіз матеріалу уможливив уточнення часу появи в історії української мови низки лексем. Цю інформацію подано у зведеній таблиці „Лексикографічне відтворення часу запозичень” [Гриценко 2017, с. 413734], де верифіковано час представлення українськими писемними джерелами запозичень, зокрема визначено для частини лексем час першого відтворення у пам'ятках (як для лексем иукор, салат, шмалець, свекла, книшь, мариипанникъ, оркишь, павидла, пампушокъ, форман та ін.) або уточнено чи змінено час. Як правило, ці уточнення засвідчують поглиблення у часі, як для лексем таляръ, мусатъ, риштунекъ, сагайдак, натарте, манеля, шата, цинамонъ, мордерско, мордериза та ін.

Ураховуючи чинник часу відбиття запозичень у писемних джерелах мов-посередниць та мові-реципієнті вдалося уточнити шлях переймання запозичень. Зокрема, германізм гелмъ, що позначав 'шолом', у писемних пам’ятках української мови засвідчений з I пол. XVII ст. (1627р.); він міг 
бути перейнятий через посередництво як старочеської мови, в яку потрапив із старонімецької у 1472 р. [SSČ I, 411], так і зі старопольської мови, у пам'ятках якої засвідчений із 1403 р. [SSP 2, 7, 542] і пізніше (1564 p. [SP 8, 321-322]). Проте наявність дериватів у старочеських пам'ятках у XIV ст. (helmodek), на поч. XV ст. (helmovnik 1417 p., helmový 1417 р., helmér XV ст., helmitý XV ст.), у XVI ст. (helmik 1515 р.) [SSČ I, 412] може свідчити про більш раннє функціонування лексеми гелмъ у старочеській мові. Відсутність дериваційного гнізда у старопольській мові і в польській мові XVI ст. дозволяє висунути припущення про можливість старочеського посередництва у процесі переймання германізму гелмъ в українську мову.

Поширеною $\epsilon$ думка, що багато германізмів прийшло в українську мову досліджуваного періоду за посередництва старопольської чи старочеської мов. Для цього є достатньо підстав, оскільки польський i чеський континуум безпосередньо межують з германським. Але є випадки, коли пам'ятки старопольської і старочеської мов не підтверджують факту посередництва в перейманні германізму в зазначений відрізок часу, що ще раз актуалізує необхідність 3'ясування історії кожної лексеми. Зокрема, в українських пам'ятках лексема голдовати 'підкорятися, бути залежним' відбита значно раніше, ніж у старопольських чи старочеських. Цей факт дає підстави припускати, що лексема голдовати є безпосереднім запозиченням 3 німецької мови, яке було посилене і підтримане пізнішим польським і чеським впливами (див. Таблиця 4).

Таблиия 4.Лексикографічне відтворення запозичених лексем

\begin{tabular}{|c|c|c|c|c|c|c|c|c|c|}
\hline Лексема & Срезн. & СДЯ & ССУМ & ICУМ & MCT & ІСУЯ & SSP & SP & SSČ \\
\hline $\begin{array}{l}\text { голдова- } \\
\text { ти }\end{array}$ & $\begin{array}{l}1395 \mathrm{p} . \\
{[1,542]}\end{array}$ & $\begin{array}{l}1388 \mathrm{p} . \\
{[2,348]}\end{array}$ & $\begin{array}{l}1388 \mathrm{p} . \\
{[1,248]}\end{array}$ & $\begin{array}{l}\text { кін. XVI ст. } \\
{[6,248]}\end{array}$ & $\begin{array}{l}1656 \mathrm{p} . \\
{[1,179]}\end{array}$ & $\begin{array}{l}1387 \mathrm{p} . \\
{[546]}\end{array}$ & $\begin{array}{l}1448 \mathrm{p} . \\
{[\mathrm{II}, 7,544]}\end{array}$ & $\begin{array}{l}1560 \mathrm{p} . \\
{[8,361]}\end{array}$ & $\begin{array}{l}1472 \mathrm{p} . \\
{[\mathrm{I}, 452]}\end{array}$ \\
\hline олдовати & - & - & $\begin{array}{l}1434 \mathrm{p} . \\
{[1,247]}\end{array}$ & $\begin{array}{c}- \\
1395 p . \\
{[\text { [ЕСУ } 1,547]}\end{array}$ & - & - & - & $\begin{array}{l}1564 \mathrm{p} . \\
{[8,361]}\end{array}$ & - \\
\hline $\begin{array}{l}\text { холдова- } \\
\text { ти }\end{array}$ & - & - & $\begin{array}{l}1445 \mathrm{p} . \\
{[1,247]}\end{array}$ & - & - & - & - & - & - \\
\hline $\begin{array}{l}\text { кголдо- } \\
\text { вати }\end{array}$ & - & - & $\begin{array}{l}1388 \mathrm{p} . \\
{[1,247]}\end{array}$ & - & - & - & - & - & - \\
\hline $\begin{array}{l}\text { голдова- } \\
\text { тисА }\end{array}$ & - & - & $\begin{array}{l}1407 \mathrm{p} . \\
{[1,247]}\end{array}$ & - & - & - & - & - & - \\
\hline
\end{tabular}

Урахування чинника часу дозволило простежити розростання 
дериваційних гнізд, що продемонстровано на прикладі лексеми жебрак. Цей приклад є показовим, оскільки засвідчує тяглість цього процесу і в сучасній українській мові.

Гніздо з основою жебр- у XVI-XVII ст.:

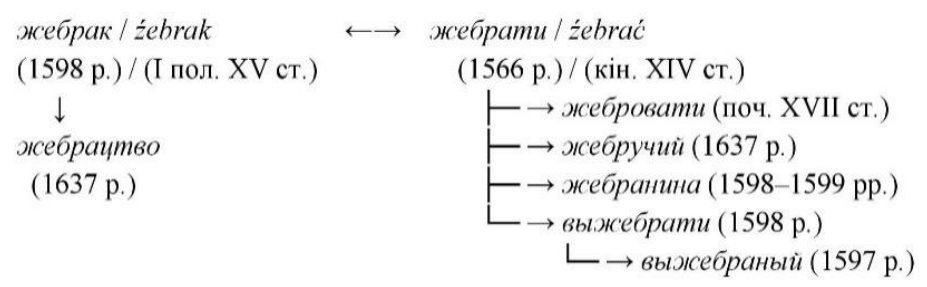

Гніздо з основою жебр- у сучасній українській мові:

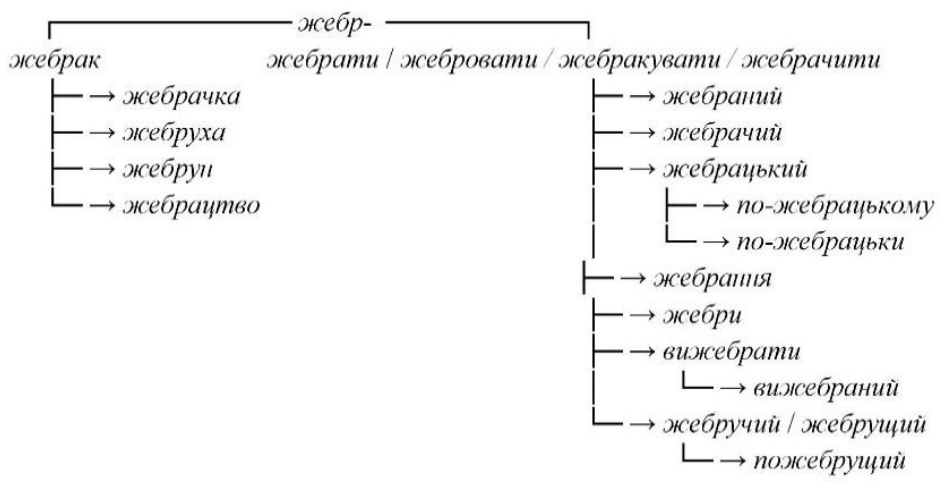

Важливе значення, на нашу думку, відіграє історія позначуваних реалій, яка сприяє уточненню часу, раніше якого ці запозичення не могли з'явитися в мові-реципієнті, зокрема: назви зброї (мушкетъ, флинта, фузбя, аркабузъ, карабинъ, сагайдак), грошових одиниць та грошових операцій (чехъ, чиншъ, дукатъ, таляръ, денга, полугрошокъ, мынца, трыбуть), напоїв (понтакъ). Історія цих лексем $\epsilon$ промовистою щодо шляху виникнення і проникнення в мову-реципієнт та проміжку часу (а саме - від 14 до 130 років) між з’явою десигната і фіксацією його назви в українських пам'ятках. Розглянемо декілька прикладів: флинта 'рушниця з кремінним затвором' з'явилася на поч. XVII ст. і використовувалася упродовж двох 
століть; у XIX ст. кремінний затвор було замінено капсульними й патронними системами, які існують і досі. Французький королівський зброяр Марен ле Буржуа створив першу рушницю із замком флінта для короля Людовіка ХІІІ у 1610 р. Нова рушниця швидко стала популярною i використовувалася в різних варіантах по всій Європі 31630 р. Історія іменованої реалії окреслює дату, раніше якої лексема флинта не могла потрапити в українську мову - 1610 р., а тому фіксація ії̈ в пам'ятках кінця XVII ст. на початку XVIII ст. $є$ виправданою і зрозумілою (пор.: „Калениченку реестъдалемъ купить мньшліонску флинту” 1717-1734 pp. [Дневник Марковича, 1, 35]).

Лексема карабинъ позначає 'вид ручної вогнепальної зброї, карабін'; сама реалія вперше з'явилася у 1498 р.; винахід приписують зброяру Гаспару Цольнеру. Лексема карабинъ українськими пам'ятками фіксується значно пізніше - у I пол. XVII ст. у „Позові ... про незаконне стягнення мита у м. Білій Церкві”: „... у ных в способъ мыта взялъ ... у Тимоша // Дорошенка - кордъ ..., у Ждана Федоренъка - лукъ зъ сагаидаком ..., у Петра Сторожа - карабинъ ...” 1628 р. [ТУВН, 285].

Ці приклади переконують ще раз у відомому положенні: без докладного вивчення історії позначуваної реалії немає наукової історії лексики, особливо, коли це стосується номінації десигнатів матеріальної культури (а не абстрактних понять). У зв'язку з цим можемо нагадати відому думку Ю. Шевельова про те, що „не можна будувати історію мовотворення і мововимирання, абстрагуючись від історичних фактів (процесів)" [Шевельов 1996, с. 195].

Зауважимо, що лінгвісти часто умовно ототожнюють час першої фіксації явищ у пам'ятках 3 часом реального постання явища. Не заперечуючи процедурного характеру такого ототожнення, поділяємо саме його умовність.

Важливим для пізнання змін у лексиконі є встановлення джерела поповнення складу лексики: чи це словотворення з уже наявного мовного ресурсу, чи це переймання з інших джерел. Зокрема, у польській мові, як мові-джерелі, засвідчені лексеми knafel 1486 р. і дериват knaflik 1437 р., які пізніше запозичені українською мовою як готові елементи (кнафель 1546 р., кнафликъ 1579 р. 'прикраса, гудзик, брошка'); або ж інший приклад: на основі італійського запозичення cavalkata у польській мові був утворений 
дериват kawalkator у 1575 p. і пізніше перейнятий українською мовою: кавалкаторь 1627 р. 'наїзник, вершник'.

3 дериватами не все так просто, бо маємо чимало прикладів, коли та сама словотвірна модель широко знана і в українській мові і в мовах, з яких запозичено багато лексем, зокрема з польської чи чеської. Наприклад, безсумнівними запозиченими лексемами, на нашу думку, $\epsilon$ иинкаръ, цьькляръ, шафаръ, грабаръ, маляръ, дракгаръ, кухаръ, бо пам'ятки польської мови фіксують ці деривати на одне-два століття раніше від українськомовних джерел (див. Таблиця 5).

Таблицяя 5.Спільні деривати: час фіксації пам'ятками

\begin{tabular}{|c|c|}
\hline Польська мова & Українська мова \\
\hline $\begin{array}{l}\text { szynkarz 'шинкар, крамар' } \\
1445 \text { р. [SSP } 8,7,592]\end{array}$ & $\begin{array}{l}\text { шинкаръ/ шинар 'працівник } \\
\text { господар шинку' } 1656 \text { р. [ЛРК, 78] }\end{array}$ \\
\hline $\begin{array}{l}\text { cektarz 'прислужник із міської охорони' } \\
1491 \text { р. [SSP } 1,4,217]\end{array}$ & $\begin{array}{l}\text { иьлклярь ‘слідчий’ II пол. XVI ст. [MCT } \\
2,472]\end{array}$ \\
\hline $\begin{array}{l}\text { szafarz'той, хто володіє і роздає } \\
\text { матеріальні блага' } 1403 \text { р., 'розпорядник, } \\
\text { керівник маєтністю, домом, володар’ XV } \\
\text { ст., ‘купець' } 1500 \text { р. [SSP } 8,7,530]\end{array}$ & $\begin{array}{l}\text { шафарь“економ, } \\
\text { управитель’ кін. XVI ст. [АЮЗР, II, } \\
216]\end{array}$ \\
\hline $\begin{array}{l}\text { grabarz 'землекоп, який копає могили' } \\
1396 \text { р. [SSP } 2,7,481]\end{array}$ & $\begin{array}{l}\text { грабарь‘особа, що копає могили’ } \\
\text { 1557-1558 рр. [Акты, III, 78] }\end{array}$ \\
\hline $\begin{array}{l}\text { malarz,malar,maler,malerz } \\
\text { маляр' кін. XIV ст. [SSP 4, 2, 146] }\end{array}$ & $\begin{array}{l}\text { малярь‘художник’ } \\
1650 \text { р. [АрхЮЗР, Ч. 3, т. 4, 486] }\end{array}$ \\
\hline $\begin{array}{l}\text { dragarz 'робітник солеварні' } \\
1363 \text { р. [SSP } 2,3,177]\end{array}$ & $\begin{array}{l}\text { дракгарь ‘візник, фурман' } \\
1598 \text { р. [ЛСБ } 1039,9]\end{array}$ \\
\hline $\begin{array}{l}\text { kucharz 'кухар, хто керує кухнею' } \\
1393 \text { р. [SSP 3, 6, 459] }\end{array}$ & кухарь‘кухар’ 1552 р. [ОВЛ3, 202] \\
\hline
\end{tabular}

Водночас $є$ чимало випадків, коли ареалом творення дериватів спільної моделі можна вважати український мовний простір, зокрема лексема собакарь 'наглядач за (мисливськими) собаками' 3 основою собак-, собака- показова у тому плані, що у польській мові, вона має порівняно невеликий ареал на північному заході - на Кашубах, які ніколи не входили у зону активної українсько-польської взаємодії. Лексема sobaka у польськомовних пам'ятках XVI ст. засвідчена як рідковживана (маємо лише 2 фіксаціiі), на відміну від лексеми pies, яку зафіксовано 831 раз і яка має розгалужене дериваційне гніздо: pieseczek, piesek, pieski, pieskow. В 
українському ареалі собака - широко знана лексема, що і дало поштовх до творення деривата собакар, який у польських писемних пам'ятках досліджуваного і сучасного періодів не засвідчений (у сучасній польській мові лексема собака вживається на позначення '(osoba) lajdak' чи як синонім до лексеми pies [SJP]). Відзначимо, що і від лексеми пес в українській мові маємо дериват псар.

Так само і лексема кобзаръ була утворена в українській мові від слова кобза, широко вживаного в українській мові досліджуваного періоду і рідковживаного (всього 4 згадки) у польських писемних пам'ятках XVI ст. Дериват кобзар у польських джерелах не зафіксований.

Окрема проблема у дослідженні динаміки лексикону - це структура номінативних одиниць. Ідеться не лише про функціонування непохідних номінативних одиниць і дериватів. Важливо не випустити з поля зору полікомпонентні номінативні одиниці - вербалізацію цілісних, неподільних за своєю сутністю понять словосполученнями, зокрема: 'повноліття' передано у пам'ятках досліджуваного періоду зуполныйзрость, 'осуджувати, ганити' - давати ганьбу і т. д. До складу словосполук могли входити як питома й іншомовна лексема, так і виключно іншомовні лексеми (контрактъ выдеркафовый 'викупний контракт'). Окремі сполуки пізніше, через свою популярність фразеологізувалися, зокрема: на шрот губу пустити 'розпустити язика, говорити дурниці', не заглядай же ты въ мою манътыку 'не втручатися до інших, займатися своїми справами', на свою руку выцвичити 'привернути на свій бік, переманити'.

Досліджуючи формування нових значень як питомих, так i запозичених лексем (внаслідок метонімії, семантичної атракції, генералізації та спеціалізації, полісемантизації та між стильової транслокації запозичень), а також активне формування абстрактної лексики у досліджуваний період, поширення виразно конотованих, оцінних елементів; аналізуючи також функційну редукцію лексикону, ми прагнули збагнути як взаємодіють механізми динаміки і водночас механізми збереження мови. Внаслідок чого досягається внутрішня рівновага динаміки і статики української мови на осі часу; і чи справді це був злам у мові, як часто говорять про досліджуваний період розвитку української мови. Тут радше варто говорити про глибоку трансформацію, активну взаємодію мов, а поняття злам використовувати лише як метафору, 
оскільки, як засвідчує матеріал, ніякого зламу у внутрішніх механізмах української мови не відбулося. Зазнаючи потужних іншомовних впливів у період XVI-XVII ст., проявивши високий ступінь вітальності на тлі латинізації, полонізації, германізації, орієнталізації тощо, українська мова водночас употужнювалася і розширювалася, зберігала своє обличчя; у цьому вважаємо одна із характерних рис української мови цього періоду. Українська мова вистояла, бо на той час це була розвинена, внутрішньо сформована, сильна система, були широкі кола їі носіїв, що забезпечували iii репродукування і збереження в часі.

\section{Словники та довідники:}

ІСУМ - Словник української мови ХVI - першої половини ХVII cm., Ін-т українознавства ім. І. Крип'якевича НАН України, Список використаних джерел,Львів (1994), 329;Вип. 1 (1994), 151;Вип. 2 (1995), 151; Вип. 3 (1996),251;Вип. 4 (1997), 259;Вип. 5 (1998), 257;Вип. 6 (1999), 255;Вип. 7 (2000), 255; Вип. 8 (2001), 255; Вип. 9 (2002), 255;Вип. 10 (2003), 255;Вип. 11 (2004), 255; Вип. 12 (2005), 244;Вип. 13 (2006), 241;Вип. 14 (2008), 255; Вип. 15 (2010), 255.

ІСУЯ - Історичний словник українського язика, уклали Є. Тимченко та ін.; зредагував

Є. Тимченко, Т. 1, зошит 1, XXIV,Харків (Держ. вид-во України, 1930), 528;T. 1, зошит 2 (Укр. рад. енциклопедія, 1932): 529-947, фотопередрук О. Горбача (Мюнхен, 1985), 947.

МСТ - Тимченко Є. Матеріали до словника писемної та книжної украӥнської мови $X V-X V I I I$ cm.: у 2 кн.,підгот.: В. В. Німчук, Г. І. Лиса, НАН України, Укр. вільна акад. наук у США, Київ; Нью-Йорк, Літопис-ХХ,Кн. 1.(2002),512;Кн. 2 (2003), 513 (Пам'ятки української мови. Серія словників).

ССУМ - Словник староукраӥнської мови XIV-XV cm.: у 2 т., редкол.: Л. Л. Гумецька (голова) та ін., Київ, Наук. думка, Т. 1(1977), 632;Т. 2 (1978), 592.

СУМ- Словник української мови: в 11 т., АН УРСР; редкол.: І. К. Білодід та ін., Київ, Наук. думка, Т. 1 (1970), 799; Т. 2 (1971), 550; Т. 3 (1972), 744; Т. 4 (1973), 840; Т. 5 (1974), 840; T. 6 (1975), 832;T. 7 (1976), 723; T. 8 (1977), 927; T. 9 (1978), 916; T. 10 (1979), 658; T. 11 (1980), 699.

Срезн. - Матеріалы для Словаря древнерусскага языка по письменнымъ памятникамъ, трудъ И. И. Срезневскаго, Санкт-Петербург: тип. Имп. акад. наукъ, Т. 1 (1893), 1420; T. 2 (1902), 1802; Т. 3 (1912), 1684: дополненія 272: дополненія къ указателямъ сокращеній, помещенныхъ въ тт. 1-мъ и 2-мъ, 13.

СДЯ - Словарь древнерусского языка (XI-XIV вв.): в 10 т., АН СССР, ИРЯ РАН; гл. ред.: Р. И. Аванесов, И. С. Улуханов, Москва, Рус. яз.; Азбуковник, Т. 1 (1988), 525 [2]; Т. 2 (1989), 493 [2]; T. 3 (1990), 510 [1]; T. 4 (1991), 557 [2]; T. 5 (2002), 647; T. 6 (2009), 742; T. 7 (2004), 505; T. 8 (2008), 762 ; T. 9 (2012), 480. 
SP - Stownik polszczyzny XVI wieku, kom. red.: Stanisław Bąk et al. (Wrocław; Warszawa; Kraków; Gdańsk, PAN), T. 1 (1966); T. 2 (1967); T. 3 (1968); T. 4 (1969); T. 5 (1971); T. 6 (1972); T. 7 (1973); T. 8 (1974); T. 9 (1975); T. 10 (1976); T. 11 (1978); T. 12 (1979); T. 13 (1981); T. 14 (1982); T. 15 (1984); T. 16 (1985); T. 17 (1987); T. 18 (1988); T. 19 (1990); T. 20 (1991); T. 21 (1992); T. 22 (1994); T. 23 (1995); T. 24 (1996); T. 25 (1997); Т. 26 (1998); T. 27 (1999); T. 28 (2000); T. 29 (2001); T. 30 (2002); T. 31 (2003); T. 32 (2004); T. 33 (2009); T. 34 (2010); T. 35 (2011).

SJP - Słownik języka polskiego, T.1-11, red. W. Doroszewski (Warszawa, Wiedza Powszechna: Państwowe Wydawnictwo Naukowe), 1958-1969.

SSČ - Gebauer, J. Slovník staročeský. Druhé, nezměněné vydáni (Praha, Academia, 1970), Díl. 1: [A-J], 674; Díl. 2: [K-N], 640.

SSP - Stownik staropolski, red. S. Urbańczyk, Warszawa [u. a.], PAN, T. 1-11 (1953-1993);

T. 1 (1953-1955); T. 2 (1956-1959); T. 3 (1960-1962); T. 4 (1963-1965); T. 5 (19651969); T. 6 (1970-1973); T. 7 (1973-1977); T. 8 (1977-1981); T. 9 (1982-1987); T. 10 (1988-1993); T. 11 (1995-2002).

\section{Література:}

1. Гриценко, С. П. «Динаміка лексикону української мови XVI-XVII ст.» Монографія (Київ, КММ, 2017), 936.

2. Лісовий, В. С. Культура - ідеологія - політика, відп. ред. О. Кобець (Київ, Вид-во ім. Олени Теліги, 1997), 350.

3. Топоров, В.Н. Миф. Ритуал. Символ. Образ. Исследования в области мифопоэтического: избранное (Москва, Прогресс: Культура, 1995), 624.

4. Шевельов, Ю. «Чому общерусский язик, а не вібчоруська мова? 3 проблем східнослов'янської глотогонії.» Історія української мови: хрестоматія, упоряд.: С. Єрмоленко, А. Мойсеєнко (Київ, 1996): 191-205.

\section{References:}

1. Gritsenko, S. P. 2017, Dynamika lekcykonu ukrajins'koji movy XVI-XVII st. [Dynamics of the Ukrainian language vocabulary of the XVI-XVII century] (Kyjiv, “KMM", 2017), 936 [In Ukr.].

2. Lisovyj, V. S. Kul tura-ideologija-polityka. [Culture-ideology-politics] (Kyjiv, "Vyd-vo im. Oleny Teligy", 2017), 350 [In Ukr.].

3. Toporov, V. N. Mif. Ritual. Simvol. Obraz. Isledovanija v oblasti mifopoenicheskoho: izbranoje [Myth. Ritual. Symbol. Image. Research in the field of mythopoetic: favorites] (Moskva, "Progres: Kul'tura", 1995), 624 [In Russ.].

4. Shevel`ov, Ju. «Chomu obshcherusskyj jazyk, a ne vibchorus`ka mova? Z problem shidnoslov`ns`koji glotogoniji». Istorija ukrajins`koji movy: hrestomatija [Why is the All-Russian language, and not the Vyborg language? On the Problems of the East Slavic Golotonia. In: History of the Ukrainian Language: Khestomatiya] (Kyjiv, 1996): 191-205 [In Ukr.]. 


\title{
АВТОРСЬКА НАРАТИВНА СТРАТЕГІЯ В І КНИЗІ ТВОРУ КСЕНОФОНТА "ВИХОВАННЯ КІРА"
}

\author{
Довбищенко Федір Володимирович, fedir.dovbyshchenko@gmail.com \\ аспірант \\ Київський національний університет імені Тараса Шевченка, \\ Інститут філології
}

У статті аналізується текст I книги “Виховання Кіра" Ксенофонта. Подається короткий опис найвагоміших праць, присвячених текстові Ксенофонта як літературній пам'ятияі. Аналіз здійснюється з позицій наратологї та рецептивної естетики. Стисло розглядаються теоретичні засади цих наук. Визначаються поняття наратора (первинного, вторинного, третинного), нарататора, автора, читача, ідеального реципіснта, преінтенції, лакуни, перипетії, золотого перетину, мовленнєвої стратегї, наративної стратегії, які необхідні для заданого типу аналізу зазначеного фрагмента. Дослідження авторської наративної стратегії відбувається через розмежування авторської та нараторської комунікацій, здійснюється спроба їх аналізу та порівняння. Вихід на аналіз подвійної структури комунікації можливий завдяки дослідженню фрагмента [Сугор. I.4.27], який привертає увагу нестандартністю в порівнянні з рештою тексту I книги “Виховання Кіра”, порушенням логіки нараторської комунікації. Припущення про те, щчо цей фрагмент слугує для виведення читача на рівень авторської комунікачії, підтверджується після наратологічного та рецептивноестетичного аналізу всієї I книги. Виявлення лакун у читацькому сприйнятті тексту, спостереження за їх розміщенням та роллю в кожному окремому випадку дозволяють зробити висновок про те, щзо фрагмент [Сугор. I.4.27] є наріжним каменем усієї I книги “Виховання Кіра”, адже лакуна у відчитуванні тексту, яку він спричинюе в читацькій активності, остаточно руйнує образ Кіра, в істинності якого має на меті нас переконати нараторська комунікація. Доведено, щзо ией фрагмент є ще й моментом сюжетної перипетії, на нього припадає золотий перетин у сюжетній структурі, подібно до будови античної трагедї. Висновки, зроблені на основі аналізу I книги “Виховання Кіра” Ксенофонта, відкривають илях для грунтовного дослідження наративної стратегії всього твору.

Ключові слова: наративна стратегія, наратологія, рецептивна естетика, авторська комунікаџія, нараторська комунікаџія, давньогрецька історіографія. 


\title{
АВТОРСКАЯ НАРРАТИВНАЯ СТРАТЕГИЯ В І КНИГЕ ПРОИЗВЕДЕНИЯ КСЕНОФОНТА "ВОСПИТАНИЕ КИРА"
}

\author{
Довбищенко Фёдор Владимирович, fedir.dovbyshchenko@gmail.com \\ аспирант \\ Киевский национальный университет имени Тараса Шевченко, \\ Институт филологии
}

В статье анализируется текст I книги "Воспитания Кира" Ксенофонта. Приводится краткое описание наиболее значительных работ, посвящённых тексту Ксенофонта как литературному памятнику. Анализ выполняется в русле установок нарратологии и рецептивной эстетики. Вкратче рассматриваются теоретические основы этих наук. Определяются понятия нарратора (первичного, вторичного, третичного), наррататора, автора, читателя, идеального реципиента, преинтенции, лакуны, перипетии, золотого сечения, языковой стратегии, нарративной стратегии, которые необходимь для анализа изучаемого фрагмента. Исследование авторской нарративной стратегии осуществляется посредством разграничения авторской и нарраторской коммуникаций, производится их анализ и сравнение. Двойная структура коммуникации проявляется в ходе анализа фрагмента [Сугор. I.4.27], который отличается нестандартностью по сравнению с остальным текстом I книги "Воспитания Кира", и характеризуется нарушением логики нарраторской коммуникации. Предположение о том, что целью этого фрагмента является выход читателя на уровень авторской коммуникации, подтверждается после нарратологического и реиептивно-эстетического анализа всей I книги. Обнаружение лакун в восприятии текста читателем, наблюдение за их размещением и ролью в каждом отдельном случае позволяют сделать вывод о том, что изучаемый фрагмент [Сугор. I.4.27] является краеугольным камнем всей I книги “Воспитания Кира", так как лакуна в прочитании текста, которую он создает читателю, окончательно разрушает образ Кира, в истинности которого стремится нас убедить нарраторская коммуникация. Доказано, что данный фрагмент является ещё и моментом сюжетной перипетии, на него приходится золотое сечение в сюжетной структуре, как и в строении античной трагедии. Заключения, сделанные на основе анализа I книги “Воспитания Кира" Ксенофонта, создают предпосылки для основательного исследования нарративной стратегии всего произведения.

Ключевые слова: нарративная стратегия, нарратология, рецептивная эстетика, авторская коммуникачия, нарраторская коммуникачия, древнегреческая историография. strategija v I knyzi tvoru Ksenofonta "Vyhovannja Kira"] (in Ukrainian) 


\title{
THE AUTHOR'S NARRATIVE STRATEGY IN THE BOOK I OF XENOPHON'S "CYROPAEDIA"
}

\author{
Fedir Dovbyshchenko, fedir.dovbyshchenko@gmail.com \\ $\mathrm{PhD}$ student \\ Taras Shevchenko National University of Kyiv, \\ Institute of Philology
}

The article deals with the text of the book I of Xenophon's "Cyropaedia”. A brief description of the most significant previous studies of the "Cyropaedia" as a literary work is given. The text is analyzed within the frames of narratology and reader-response criticism. The theoretical base of these approaches is shown concisely in the beginning of the article. The notions of narrator (primary, secondary, tertiary), narratee, author, reader, ideal recipient, pre-intent, lacuna, peripeteia, golden section, lingual strategy, narrative strategy are being defined as the main notions of the present investigation. The study of the author's narrative strategy supposes a distinction between authorial and narratorial communication with its further comparison. The analysis of a doublestructured communication is possible thanks to the study of the given fragment [Cyrop. I.4.27]. It draws the attention because it is unusual if compared with the rest of the book I, the narratorial communication lacks logics in this very fragment. The assumption that the fragment could be a key for understanding the authorial communication is proved by the analysis of the whole book I within the frames of narratology and reader-response criticism. Finding lacunas in reader's reception of the text as well as observation of their place and role in each case allows to conclude that [Cyrop. I.4.27] is a cornerstone of the whole book I of the "Cyropaedia". The lacuna this fragment provides to the reader ruins absolutely the image of Cyrus, which the author of narration tries to persuade us to be real. It is proved that the present fragment is, in addition, a moment of peripeteia and of golden section it the structure of the book I which is similar to that of the ancient tragedy. The conclusions of the present article give way to a thorough narratological analysis of the whole "Cyporaedia" of Xenophon.

Key words: narrative strategy, narratology, reader-response criticism, authorial communication, narratorial communication, ancient Greek historiography.

Вступ. Дослідження античного історіографічноготексту як наративу $\epsilon$ привабливим 3 точки зору перспектив, які відкривають наратологія та рецептивна естетика. Ці науки уможливлюють аналіз пам'ятки не лише як надійного або непевного джерела історичного знання, а й як мовленнєвого акту, із застосуванням методів, притаманних такому підходові (дискурсаналіз, структурно-функціональний аналіз тощо). Попри великий потенціал 
наратологічних і рецептивно-естетичних студій, які дають можливість відтворити умови і мету написання твору, слід відзначити брак і практичну відсутність літератури, присвяченої аналізові I книги "Виховання Кіра" Ксенофонта $з$ позицій наратології та рецептивної естетики. Д. Л. Гера в монографіï "Xenophon's Cyropaedia Style, Genre and Literary Technique" [Gera 1993] подає детальний аналіз міжтекстової інтерференції, порівнюючи настанови Камбіза Кірові в I.6 із паралельними місцями в Memorabilia. Питання, яке нас цікавитиме в цій статті, а саме: мета Камбіза в його повчанні, пояснюється таким чином, що останній не мав на меті навчити Кіра тактики, вважаючи таку інформацію "надто технічною" для дидактичного діалогу [Gera 1993, с. 71]. Ми спробуємо розвинути цю думку, поглянувши на проблему крізь призму наратології та рецептивної естетики. Дослідження діалогу Кіра з Манданою [Gera 1993, с. 73-78], де той переконує іiі залишити його в Мідії, переконливо показує прозірливість Кірової матері: вона боїться, що мідійська розкіш його зіпсує. Цікавим $є$ також аналіз уявлень про справедливість у персів та мідійців, який авторка здійснює в цьому розділі. Нашим же завданням буде показати роль “мідійського впливу”, у вирішальних учинках Кіра в I книзі.

К. Відден у статті “The Account of Persia and Cyrus's Persian Education in Xenophon's Cyropaedia" [Whidden 2007] порушує проблему політичних результатів діяльності Кіра 3 погляду Ксенофонта. Його імперія не могла протривати довго й не несла в собі хороших зачатків, тому, на думку автора, Ксенофонтів твір слід сприймати як іронію. Ми погоджуємося з тим, як автор інтерпретує загальний посил праці, i спробуємо дослідити “іносказання” в I книзі “Виховання Кіра".

П. В. Сейдж у статті “Dying in Style: Xenophon's Ideal Leader and the End of the "Cyropaedia." [Sage 1994] постулює абсолютну доречність змісту заключного розділу праці Ксенофонта, де показана руйнація держави після його смерті. Логічність і вмотивованість такого епілогу авторка доводить через його перегукування з передмовою в I книзі, де йшлося не про те, що Кір стане мудрим правителем, а про те, що він здобуде владу над багатьма народами. Ми вважаємо, що передмова та епілог "Виховання Кіра" виступають в опозиції до решти тексту, якщо брати до уваги нараторську комунікацію, проте $\epsilon$ незворотними логічними етапами, коли розглядати їх через комунікацію авторську. Перша книга "Виховання Кіра" містить 
засновки до відчитування авторської комунікації через лакуни в нараторській, що ми і спробуємо довести.

Дж. Татум у роботі “Xenophon's Imperial Fiction: on the Education of Cyrus" [Tatum 1989] робить цікаві висновки про алегорію стада в передмові праці Ксенофонта. Така алегорія, на думку автора, покликана показати відірваність царенка від людей і певне його ментальне наближення до покірних тварин, з якими йому легше знайти спільну мову [Tatum 1989, с. 64]. На нашу думку, такі Кірові схильності справді мають місце в діалозі з батьком, коли він невідступно, як мантру, повторює своє запитання про те, як досягти влади над людьми, а все інше його не цікавить. Наратологічний аналіз I книги “Виховання Кіра” підтверджує цю тезу.

Об'єктом пропонованого дослідження є текст I книги “Виховання Кіра” Ксенофонта, який розглядається під кутом зору наратології та рецептивної естетики.

Предметом дослідження $\epsilon$ структура комунікації та прийоми наративної стратегії, реалізовані в тексті.

Метою статті $є$ встановити, в чому полягає авторська наративна стратегія I книги “Виховання Кіра”, і якими прийомами вона реалізується.

Поставлена мета передбачає наступні завдання:

- перевірити наявність і розрізнити авторську і нараторську комунікації;

- 3'ясувати мету обох комунікацій;

- проаналізувати вплив на читача і роль композиційної організації I книги "Виховання Кіра";

- вийти на розуміння наративної будови I книги “Виховання Кіра”, iii комунікативного повідомлення.

У нашому аналізі ми послуговуємося законами й термінологією, розробленими в рамках наратології та рецептивної естетики. Основні положення цих наук висвітлені у статтях [Довбищенко 2015] та [Довбищенко 2017]. Тут наведемо лише коротке тлумачення термінів, які будуть використані у пропонованій статті.

Наратор - “той, хто розповідає в тексті" [Ткачук 2002, с. 83], “голос", який промовляє, відповідає за акт нарації, оповідаючи про подію як “правдиву історію” [Антологія 1996, с. 799]. Наратор, що належить не до реального, а до текстуального світу, передає розповідь іншій його частині - 
нарататорові. Нарататор (фр. narrataire) $є$ адресатом наратора, тою інстанцією, до якої звернена його розповідь [Genette 1972, с. 226].

У наративних текстах прийнято виділяти подвійну структуру комунікації, адже наратор та нарататор $є$ компонентами світу, який зображується в тексті автором, а адресатом авторського повідомлення виступає читач. На відміну від наратора та нарататора, дві останні інстанції існують у реальному світі: автор є конкретною особою, існування якої не обмежене текстом. Читач, як і автор, є певною особою, яка сприймає твір як авторське повідомлення і так само існує поза текстом [Шмид 2003, с. 41]. Подвійну структуру комунікації в наративному тексті можна зобразити у вигляді схеми [Шмид 2003, с. 35]:

Авторська комунікація:

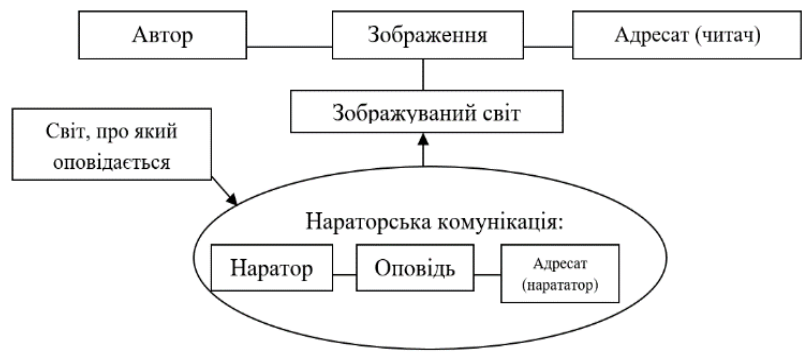

Як бачимо, нараторська комунікація є складовою частиною авторської, причому відноситься саме до зображуваного автором світу, адже, як ми побачимо далі, i наратор, і його уявний адресат, і повідомлення, яке йому передається, формуються авторською уявою.

Ідеальний реципіснт - це інстанція, яку абстрактний автор розглядає як носія однакових з ним цінностей, що дозволить йому повністю і без спотворень сприйняти авторське повідомлення [Шмид 2003, с. 61-62].

Терміни “первинний наратор", “вторинний наратор” i “третинний наратор” були запроваджені Бертилом Ромбергом [Romberg 1962 , с. 63]. Один 3 персонажів твору у якийсь момент може стати оповідачем, переповідаючи якусь історію. У даному випадку цей персонаж стає вторинним наратором. Коли ж і в цій історії міститься ще один, включений (embedded) у неї наратив, його суб'єкт виступає по відношенню до основного наративу третинним наратором. 
Засновник рецептивної естетики В. Ізер згадує тезу Е. Гусерля про преінтенції - оформлені в окремих реченнях “сподівання на те, що має надійти” [Антологія 1996, с. 352]. На основі цих суджень В. Ізер робить висновок про існування дійсного виміру тексту, який формується самим текстом та уявою читача [Там само, с. 353]. Таким чином, читання є творчим процесом, далеким від простої перцепції написаного [Там само, с. 353].

Якщо наступне речення в тексті не має відчутного зв'язку з тим, яке продумав читач, то у свідомості відбувається блокада, яку Р. Інгарден називає лакуною. Читач на власний розсуд заповнює лакуну, і в цьому акті виявляється динаміка читання. Фазами тексту, таким чином, є антиципація і ретроспекиія: читач постійно подумки передбачає те, про що йтиметься у тексті, і водночас згадує вже прочитане. Саме антиципація та ретроспекція призводять до утворення дійсного виміру тексту [Там само, с. 355].

За Аристотелем, “перипетія $(\pi \varepsilon \rho \imath \tau \varepsilon ́ \tau \varepsilon ı \alpha) \ldots \epsilon$ зміною дії на свою протилежність, і при цьому ... зміною імовірною або необхідною" [Aristotelis 1911, 1452a]. Термін широко використовується в літературознавстві.

Золотий перетин - термін, що виник в архітектурі. Позначає таке співвідношення величин, при якому їх сума так відноситься до більшої частини, як більша частина - до меншої [Mario 2003, с. 35].

Під мовленнсвою стратегією розуміють “сукупність мовленнєвих дій, спрямованих та вирішення загального комунікативного завдання мовця (глобального наміру, за ван Дейком)" [Иссерс 2008, с. 109]. Наративну стратегію розглядатимемо як різновид мовленнєвої у рамках такого типу комунікації, як наративний текст.

Читаючи "Виховання Кіра" Ксенофонта, неможливо не звернути увагу на фрагмент, який міститься в 27 частині I книги. У ньому йдеться про зустріч Кіра із закоханим у нього мідійцем. Дія відбувається під час від’їзду перського царевича додому з Мідії. Під приводом, буцімто $є$ його родичем, закоханий просить у Кіра поцілунку, а потім ще й наздоганяє його, коли той уже від'їхав, і знову вимагає свого. Кір цього разу не повторює “ритуалу”, але обіцяє повернутися на радість мідійцеві, і той, мовляв, бачитиме його, якщо тільки забажає.

Немовби будучи свідком усієї цієї історії та іï позірної недоречності 
3 точки зору композиції твору, наратор вводить їі в текст, обмовившись так:

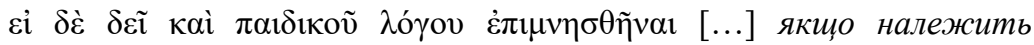
пригадати і грайливу історію [...][Xеnophon 1800, I.4.27].

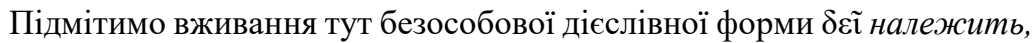
потрібно. Це слово немовби підкреслює доречність вставки. Але починається речення з умовного сполучника єі якщцо. Тобто, з одного боку,

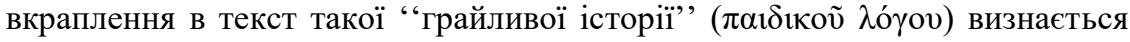
необхідним з точки зору побудови твору, а, з іншої, ця необхідність піддається сумніву. Вживання casus realis як типу умовного речення хоча й ставить під сумнів доцільність відступу, проте, водночас, заявляє про прямий логічний зв'язок підрядного речення 3 головним i цілковиту реальність умови. Сенс речення стає подвійним: фіктивний читач, ідеальний реципієнт, який сліпо вірить нараторському текстові, прийме ці “перепросини", й вирішить, услід за наратором, відпочити від самої серйозності проблематики “Виховання Кіра”, заявленої в проемії (туди ми ще повернемося). Читач же, який уважніше ставиться до тексту, помітить дивну двозначність речення, яке передує “любовній пригоді'”: навіщо перепрошувати, маючи вже цілком, здавалося б, удатний привід ““знизити рівень" повідомлення? Історія взагалі видається дивною в рамках усього тексту: більше ніде наратор не вставляє історій “просто для забави"; у першій книзі горе-коханець більше не фігурує. Спадає на думку, що не він $\epsilon$ головним героєм історії, тому й роль його тут і далі епізодична. I справді: головним героєм є Кір. Дозвольмо собі висловити припущення, що він і тут лишається в окресленому статусі. Та й текстово він $є$ центром уваги: історія про коханця обрамлюється описами внутрішнього стану головного героя. Погляньмо:

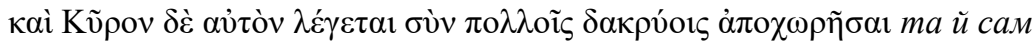
Кір, кажуть, від’їхв, гірко ридаючи (дослівно - “‘з численними слізьми”') [Xenophon 1800, I.4.26].

Так описується душевний стан Кіра по від’ізді. Аорист, вжитий у реченні, наголошує на тому, що царенко вже відбув. Прощальні поцілунки родичів і того коханця, який видав себе за родича, вже відбулися, і Кір від’іжджає засмученим, але наратор переставляє події місцями: “любовна історія', впроваджена в текст згаданою вже підозрілою фразою, починається $з$ опису прощання, коли Кір ще не відбув, а ось-ось відбуде. 
Настрій головного героя в такий спосіб завуальовується: вставці передує благородний учинок Кіра - повернення дарів Астіагові, щоб той роздав їх наближеним перського царенка, причому робить він це зі словами:

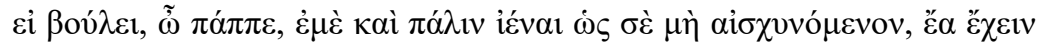

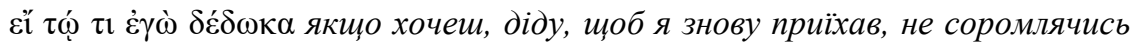
тебе, дозволь усякому мати те, щчо я дав [Хеnophon 1800, I.4.26].

Ця фраза виставляє на перший план благородство Кіра. Читач переміщується, услід за наратором, до любовної пригоди, уже маючи в голові цей образ Кіра - благородного й великодушного. Його моральний стан під час від'їзду забувається. Нараторське завуальовування істинного настрою Кіра підкріплюється зображенням його поведінки щодо нахабного прохача: він не знає, чи той $є$ його родичем, але охоче (чи, можливо, умисне) вірить йому на слово. Нараторський текст протирічить сам собі. У фрагменті, який впроваджує любовну історію (ми про нього вже згадували), первинний наратор протиставляе “коханця” і родичів Кіра:

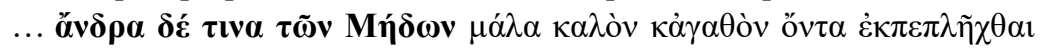

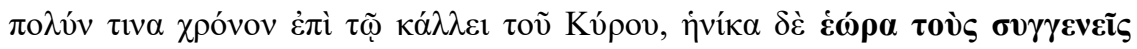

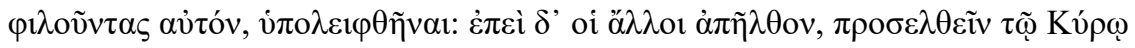
каі̀ єілєі̃v ... один мідієць, прегарний і преблагочестивий, уже довго був у захваті від Кірової краси, а тепер, коли побачив, що родичі його цілують, відсторонився; коли ж інші відійшли, наблизився до Кіра і мовив [Хеnоphon 1800, I.4.27].

Проте в тексті вторинного наратора (в діалозі Кіра з “коханцем”) царенко показно не лише охоче вірить “"родичеві”, а й, як видається, цілком поділяє прагнення нахаби:

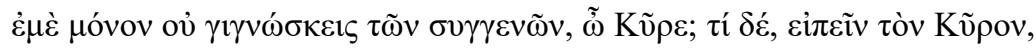

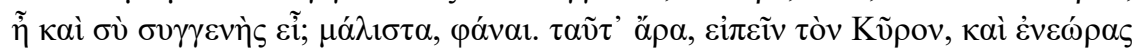

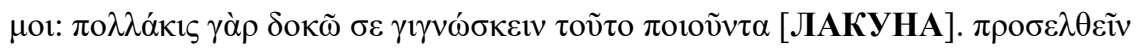

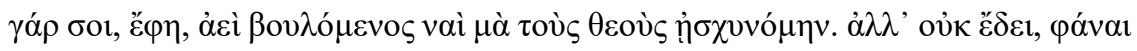

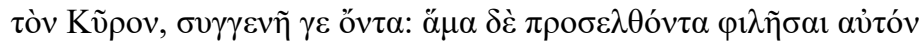

- Ти мене єдиного не визнаєш родичем, Кіре?

- Що, - каже Кір, - і ти мені родич?

- Нузвісно! - каже.

- Тому, - мовить Кір, - ти й дивишся так на мене: здається, я 
часто помічав, як ти це робиш [ЛАКУНА].

- Я завжди хотів до тебе підійти, - каже той, - але, присягаюсь богами, соромився.

- Та не треба було, - відповідає Кір, - адже ти мені родич. І одразу підійшов і поцілував його [Хеnophon 1800, I.4.27].

У діалозі ми позначили місце, де у відчитуванні тексту відбувається блокування потоку речень - лакуна. Адже попередня нараторська інформація вступає в дисонанс із новою: виявляється, що Кір, навпаки, зараховує того чоловіка до своїх родичів. Таким чином, відбувається порушення логіки нараторської комунікації. Спостерігаємо не один, а два образи Кіра: він постає, в інтерпретації первинного наратора, благородним і великодушним 3 огляду на вчинки, які передували від'іздові, і ця інтерпретація слугує немовби підгрунтям для “правильного” трактування ідеальним реципієнтом того, як Кір повівся 3 прохачем: царенко в благородному пориві зглянувся на його “любовне безумство”, ніби продовжуючи логіку великодушних учинків. Але через мовлення вустами вторинного наратора виявляється інший образ головного героя: його відповідь “Ну звісно!” демонструє відсутність вірності принципам, переконанням i, що найсуттєвіше, традиції, оскільки на початку вставки наратор не випадково зазначив, що поцілунки родичів є перським звичаєм. Нарататор, проте, може йти за логікою первинного наратора до кінця діалогу, адже “великодушний” Кір дозволяє себе поцілувати ще двічі: тут же і коли “'коханець” його наздоганяє, щоб імітувати розлуку і повторну зустріч. Нараторська логіка, яка підносить “великодушність” Кіра, остаточно порушується, коли одразу по цій пригоді ми читаємо про зміну його настрою:

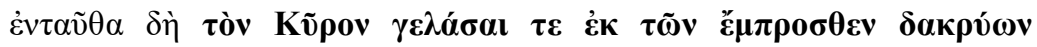

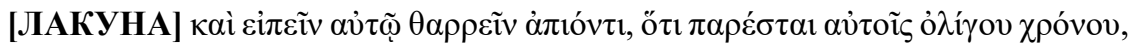

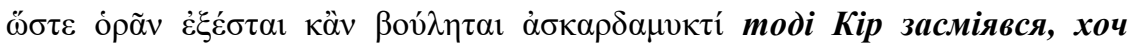
раніше плакав [ЛАКУНА], і сказав йому йти з певністю в сериі, бо він незабаром знову приїде до них, і тому буде дозволено його бачити як завгодно довго, якщя захоче [Хеnophon 1800, I.4.28].

Такий перехід спровокований компліментом “коханця":

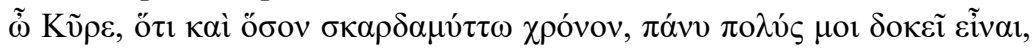

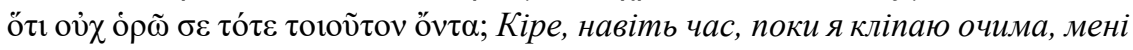
здається неймовірно довгим, бо тоді я не бачу тебе ось такого! [Xеnophon 1800, I.4.28]. 
Виходить, що відверті лестощі здатні впливати на настрій головного героя настільки сильно, що повністю змінюють його. Нарататор, який ішов за наратором і вірив у великодушність Кіра як рушій його вчинків, змушений змінити думку: царенко виявився готовим догодити нахабі, якого бачить уперше і не впізнав серед родичів, в обмін на похвалу й лестощі. Це протиріччя провокує лакуну у відчитуванні тексту читачем: “благородний і великодушний" Кір під впливом однієї фрази раптом виявляє свою внутрішню сутність, яка аж ніяк не збігається 3 тим, у чому хотів нас переконати первинний наратор, описуючи його від’ізд iз Мідії. Слід підкреслити тенденцію в авторському виборі наратора: коли автор прагне вселити нам віру в чесноти Кіра, тип наратора - первинний (розповідь ведеться від третьої особи), як у фрагменті, де Кір від’іжджає “гірко плачучи'; коли ж автор має на меті показати істинний внутрішній світ протагоніста, то наратор є або вторинним (включення прямої мови), як у першому діалозі з нахабою, або первинним, але репліки героїв передаються через непряму мову, як в описі реакції Кіра на комплімент.

Тепер стає зрозумілою логіка цілої вставки. Вона допомагає читачеві викрити подвійну структуру комунікації в I книзі “Виховання Кіра”, Ксенофонта. Нараторська комунікація зображає перського царенка як благочестивого парубка, сповненого великодушних поривань. Авторська комунікація малює перед нами зовсім інший образ: це людина, яка не здатна впокорити випадкові примхи і чий настрій цілковито залежить від їхньої реалізації.

Наголосимо тут на тому, що праця Ксенофонта називається

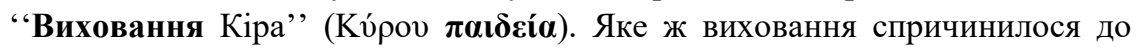
того, що головний герой так легко став заручником власних примх? Спробуємо розібратися.

На початку твору наратор аргументує свою цікавість до постаті Кіра. Вона обумовлена так:

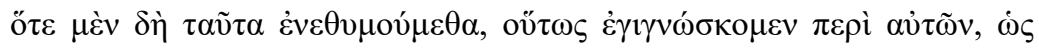

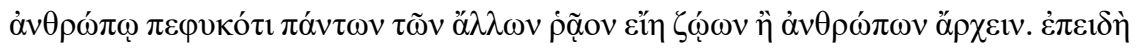

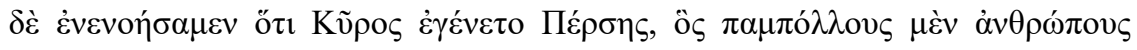

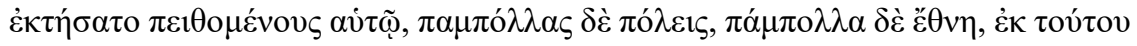

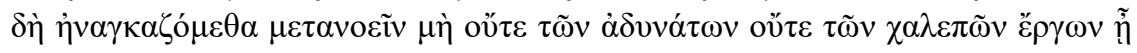




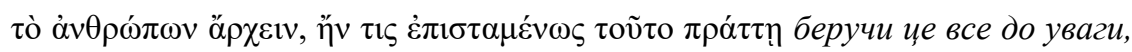
ми робили висновок, що людині легше владарювати над усіма іншими істотами, ніж над людьми. Та коли ми помітили, що був такий собі Кір, перс, який здобув владу над безліччю людей, щуо ӥх змусив собі коритися, над незліченними містами й народами, то довелося нам змінити думку: владарювання над людьми не є ані неможливим, ані важким завданням, якщчо робити ие вміло [Хеnophon 1800, I.1.3].

Як бачимо, наратора цікавить, як можна здобути владу над величезною кількістю людей. 3 одного боку, це банальний факт, але, 3 іншого, дуже важливо на ньому наголосити: в передмові мотивом до написання праці висувається саме спосіб здобуття влади. У заключній частині проемію наратор логічно пов'язує необхідні для цього якості 3 вихованням, яке має отримати майбутній володар народів:

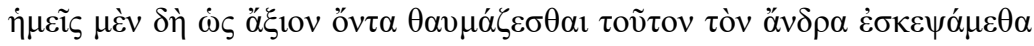

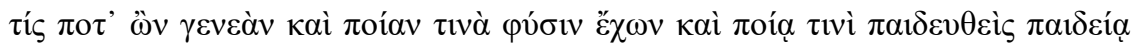

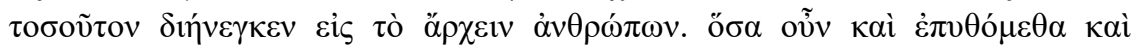

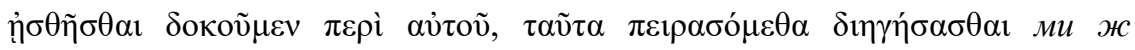
дослідили, якого роду, якої природи був цей гідний подиву чоловік, яке він отримав виховання, щчо дозволило йому правити над стількома людьми. Те, що ми дізналися $і$ вважаємо достовірним, спробуємо тут розповісти [Xenophon 1800, I.1.6].

Можемо сформулювати мету твору одним реченням, покладаючись на слова наратора: з'ясувати, яке виховання дає змогу керувати людьми. Це преінтенція твору: читач очікуватиме відповіді саме на це питання. Преінтенція також дає підстави вважати, що виховання було, причому мало бути настільки якісним, щоб забезпечити виконання Кіром надскладного завдання - розповсюдження своєї влади над іншими народами.

У другому розділі I книги, одразу на його початку, наратор починає реалізовувати преінтенцію: оповідає про давнє (навіть божественне) походження Кірового роду, красиву зовнішність. Торкається оповідач і його природних якостей. Вони, за логікою тексту, закладеною в преінтенції й розвинутою в описуваних тепер рядках, мають поступово вималювати образ молодої людини (чи хлопчика), від природи наділеної всіма чеснотами, як зовнішніми, так і внутрішніми. Проте одна деталь випадає з цього ряду:

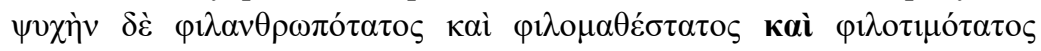
strategija v I knyzi tvoru Ksenofonta "Vyhovannja Kira"] (in Ukrainian) 


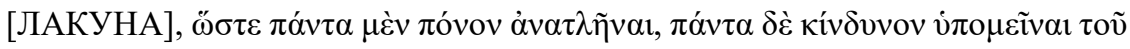

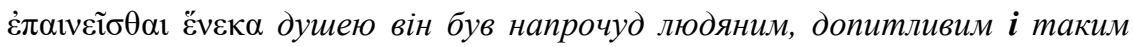
шанолюбним [ЛАКУНА], щңо ладен був стерпіти будь-які поневіряння й піддати себе будь-якій небезпеці заради похвали [Xеnорhon 1800, I.2.1].

Дві перші якості, згадані наратором, є позитивними. Третя, шанолюбність ( Проте включена вона в речення сполучником каі́ $i$, який ставить знак рівності між першими двома якостями і третьою. У цьому фрагменті закладається протиріччя між авторською та нараторською комунікаціями: шанолюбство починає сприйматися, з одного боку, як позитивна якість (адже воно ставиться в один ряд із людяністю й допитливістю), а, з іншого,

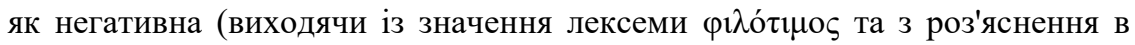
кінці речення, яке показує, до чого довела Кіра ця шанолюбність). Згаданий фрагмент створює прецедент, про який ми незабаром поговоримо.

Наступні рядки описують систему виховання персів. Це елітарний привілей (бідні не мають туди доступу [Xenophon 1800, I.2.15]) для багатої знаті. Ця-ось знать (решта населення просто працює) розділена на чотири вікові категорії: діти (до 16-17 років), ефеби (до 27 років), дорослі чоловіки (ще 25 років) і старійшини. Основна наука, яку опановують діти, - це наука справедливості [Xenophon 1800, I.2.6-8]. Ї̈̈ перси вважають найважливішою. Звернімо увагу на тривалість юнацького виховання: до 17 років. І весь цей час, як випливає з тексту, діти опановують науку справедливості, вершачи суд, а наставники стежать, щоб ті поводилися пристойно.

Така система виховання, на думку наратора, закладає основи гідної поведінки персів:

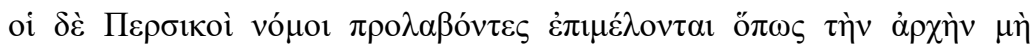

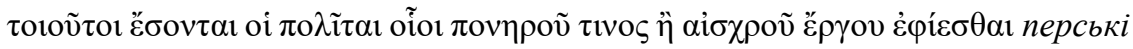
ж закони заздалегідь дбають про те, щоб громадяни не стали такими, щоб дозволити собі поганий або негідний учинок [Xenophon 1800, I.2.3].

Основа виховання перського громадянина, як ми вже переконалися, закладається в дитячому віці (що триває до 17 років) через пізнання науки справедливості. Далі, звісно, починається не менш важливий етап - парубки стають ефебами (з 17 до 27 років). Підсумовуючи зміст їхнього виховання згідно з текстом, можемо сказати, що головне, чого вони навчаються, - це 
витривалість (яка відточується на полюваннях) і самовдосконалення у постійних змаганнях [Xenophon 1800, I.2.9-12]. Але хлопчики, які не закінчили виховання як діти, не мають права перейти до стану ефебів:

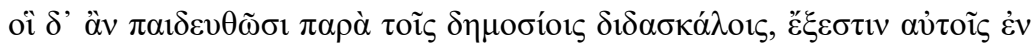

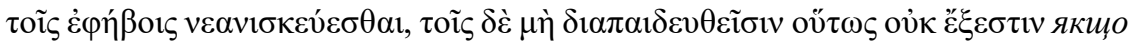
вони отримають виховання у державних учителів, то їм дозволяється провести юність серед ефебів; тим же, які не отримали такого виховання, иього не дозволено [Xenophon 1800, I.2.15].

Здавалося б, Кір як спадкоємець престолу повинен пройти не тільки описаний курс виховання, а й набагато глибший, 3 огляду на відповідальність, яка лежатиме на ньому в майбутньому. Проте третій розділ I книги, який починається майже одразу після щойно наведеної тут цитати, одразу заявляє про недотримання Кіром правил виховання:

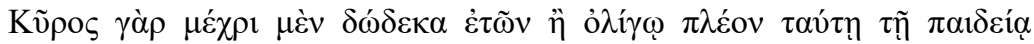

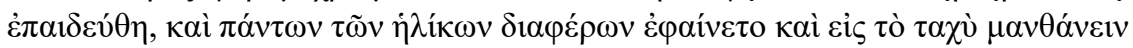

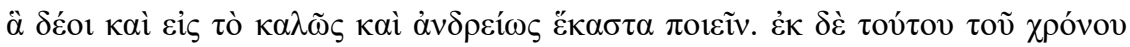

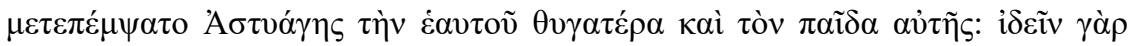

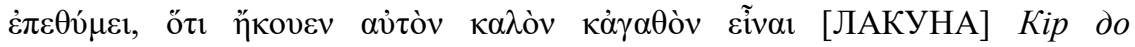
дванадияти років або до трохи старшого віку виховувався таким способом, вирізнявся серед усіх своїх однолітків тим, щзо швидко вивчав, щцо було потрібно, і тим, що все робив із благородством імужністю. А в цььому віці запросив Астіаг [дід Кіра, иар Мiдiї - Ф.Д.] до себе свою дочку та їі сина: палко-бо він бажав його побачити, адже чув про його красу й доброчесність [ЛАКУНА] [Хеnорhon 1800, І.3.1].

На момент від'їзду Кірові виповнилося дванадцять років, тобто лишалося ще п'ять років виховання у державного вчителя. Але, відбуваючи до Мідії, Мандана, його мати, перервала виховання. У цьому полягає лакуна в читацькому сприйнятті нараторського тексту: преінтенційно, з огляду на попередні цитати, нарататор мусив очікувати продовження логіки ідеального виховання царенка, але вона порушується. Причому аргументацією такого порушення, яка ще більше “поглиблює” лакуну, виступає бажання Астіага побачити на власні очі красу і чесноти Кіра, і краса тут стоїть на першому місці. Іншими словами, спостерігаємо висування на перший план зовсім не тих якостей, які були метою перського виховання. Наступна лакуна взагалі нівелює смисл виховання Кіра, бо 


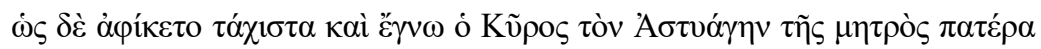

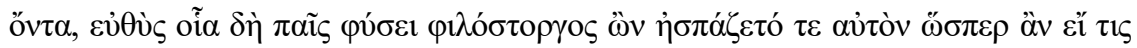

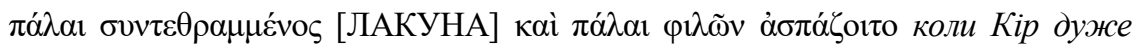
швидко прибув і дізнався, що Астіаг є батьком його матері, відразу, був-бо дитиною й від природи ніжним, тепло привітав його, наче той, хто змалечку з ним зріс і віддавна був його другом [ЛАКУНА][Хеnоphon 1800, I.3.2].

Далі текст демонструє історію поступового морального падіння Кіра, пов'язаного з тим, що близькі потурали його примхам. Особливо показовими 3 цієї точки зору є історія 3 полюванням [Хеnophon 1800, I.4.14-15], де малолітній Кір домагається зміни поведінки свого діда Астіага від повної заборони до надання свободи дій, і епізод із відбиттям збройного нападу на Мідію, де Кір не лише змушує старших дозволити йому брати участь у поході, а й сам без жодного на це права починає бій, ледь не погубивши при цьому власне (ба навіть не своє, перське, а мідійське) військо [Хеnophon 1800, I.4.2024]. Все це відбувається за мовчазної згоди Астіага, який спершу вдавано намагається корити Кіра за ці безглузді вчинки, а потім доходить до захвату ними [Хеnophon 1800, I.4.25]. Попри очевидну поразку й без того жалюгідних виховавчих зусиль Астіага, у згаданих фрагментах наратор ще переконує нас у тому, що в того принаймні на початках був намір провчити Кіра, але він змушений був скоритися громадській думці:

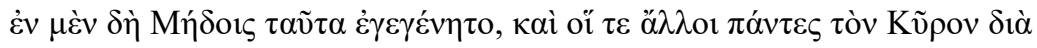

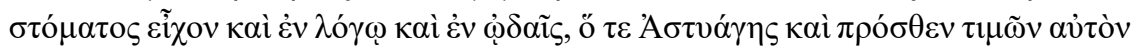

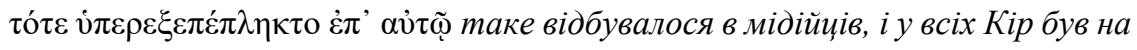
вустах у промовах і піснях; Астіаг же, який і раніме шанував його, тепер був ним вражений [Xenophon 1800, I.4.25].

І ось тепер текст повідомляє нам про від’їзд Кіра з Мідії, і наратор, ніби перепрошуючи за це, вставляє історію з “коханцем”. Ї̈і відмінність від попередніх історій про догоду Кіровій лестолюбності полягає в тому, що найприємнішу для себе нагороду - лестощі - царенко отримує вже не за те, що зробив “героїчний” учинок і йому пощастило при цьому не загинути, а без жодного приводу. Це остаточно переконує його у власній всемогутності й безкарності, що й доводиться його рішенням взяти на себе відповідальність і виступити проти ассирійського царя [Хеnophon 1800, I.5.4-5]. Перед читачем постає логічне запитання: як Кір може керувати 
військом, не маючи за плечима жодного досвіду, крім необдуманої божевільної атаки, яка ледь не закінчилася його загибеллю?

Мотивація Кіра розкривається в його промові до воїнів [Хеnophon 1800, I.5.7-14]. Надихнути їх на звершення подвигів він намагається, апелюючи до вузькоматеріальних інтересів і слави, що лише прикриваються потребою захищати союзника (Мідію), як це зображувалося на початку розділу [Хеnophon 1800, I.5.2-4]. Подивімося, якими є його аргументи:

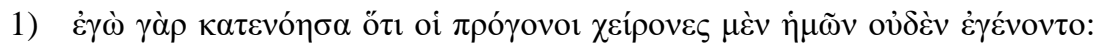

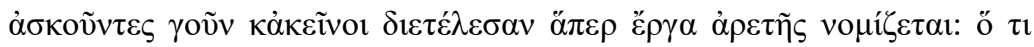

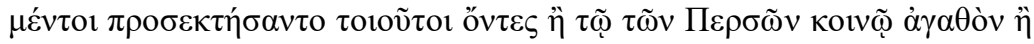

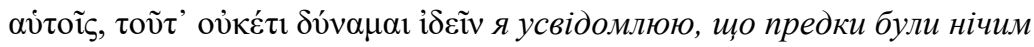
не гіршими за нас: адже й вони ревно прагнули звершити те, щзо вважається доброчесними справами; та я ніяк не можу побачити, що вони, будучи такими, надбали або для спільного перського блага, або для самих себе [Xenophon 1800, I.5.8];

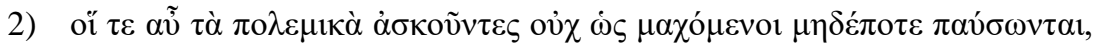

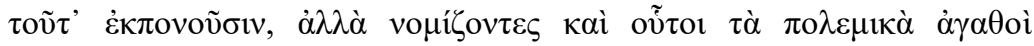

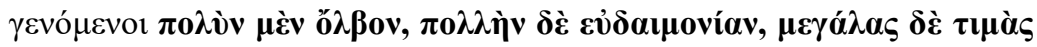

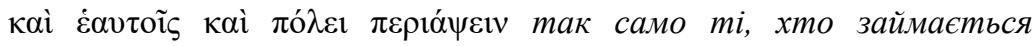
військовою справою, роблять це не для того, щчоб ніколи не припинити, але й ті, хто здобув військову доблесть, сподіваються надбати великого багатства, процвітання $і$ глибокої пошани самим собі й державі [Xеnophon 1800, I.5.9];

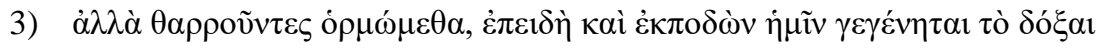

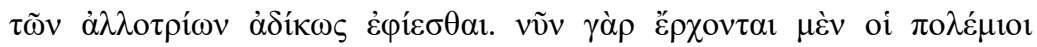

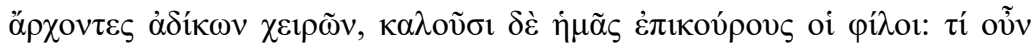

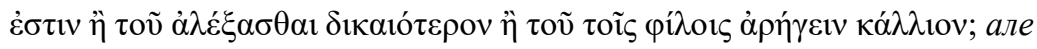
сміливо йдімо на ворога, адже аж ніяк не може здатися, щчо ми несправедливо прагнемо чужого. Зараз-бо йдуть на нас вороги, починаючи несправедливе насильство, а друзі кличуть нас на допомогу: що ж є справедливішим за відбиття нападу, $і$ щзо є кращим за допомогу друзям? [Хеnophon 1800, I.5.13]

Як бачимо, Кір навіть не намагається приховати свої справжні прагнення. Слід відзначити також упевненість, яка пронизує промову. Такої впевненості в царенка в Мідії не було, вона з'явилася тільки після зустрічі 3 
“коханцем”.

Завершальним фрагментом I книги є діалог Кіра з батьком [Хеnophon 1800, I.6]. Дія розгортається, коли перське військо на чолі з Кіром уже виступило в похід, і Камбіз починає розмову, супроводжуючи його до кордону. Мова йде про військову справу. Дивною $є$ сама ситуація: вже почалася війна і військо виступило в похід, а полководець тільки починає отримувати перші поради. Наведемо тут найяскравіші місця з діалогу:

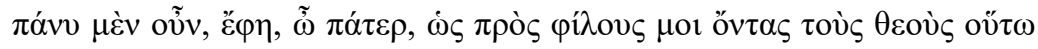

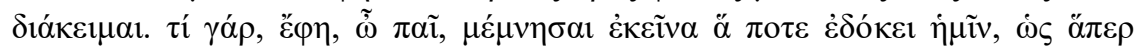

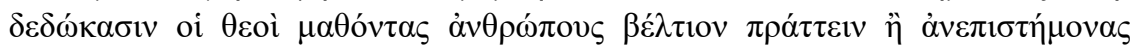

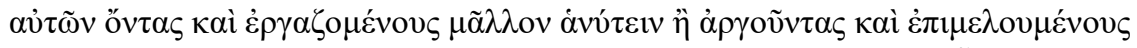

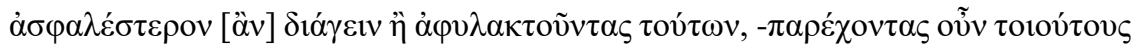

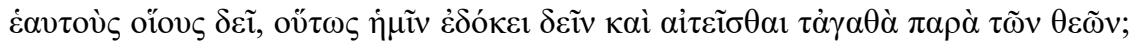
Цілком так, - каже, - батьку, я достеменно знаю, що боги мені як друзі. Що ж, - каже батько, - ти, сину, запам'ятав з того, що колись спало нам на думку, що боги дали вмілим людям краще жити, ніж неукам, $i$ працьовитим - більшого досягати, ніж неробам, а дбайливим - безпечніше прожсивати вік, ніж недбалим; якщо вони роблять себе саме такими, як належить, то й нам здавалося, що так потрібно робити, а тоді просити блага в богів? [Xenophon 1800, I.6.4-5].

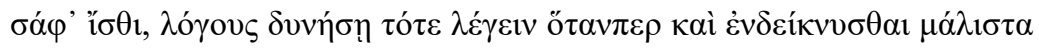

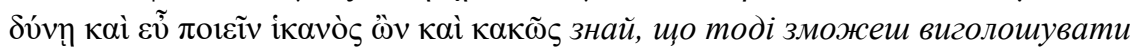
промови, коли справами доведеш, що здатен робити і добрі, й погані вчинки [Xenophon 1800, I.6.10].

Як бачимо, Камбіз усвідомлює, що Кір просто некомпетентний, і починає пояснювати йому елементарні речі, які навіть не стосуються прямо військової справи; іншими словами, батько бачить мотив сина (досягти слави в найлегший спосіб) і намагається зарадити проблемі. Все це

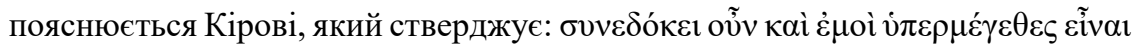

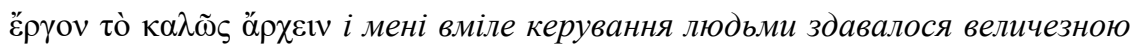
справою [Хеnophon 1800, I.6.8].

Подальше розгортання діалогу викриває повну некомпетентність Кіра у військовій справі: він учився тактики, не знаючи, як набирати, тренувати i забезпечувати військо, і взагалі не уявляє, що має робити полководець. Більш 
того, видається, що практичні вміння полководця його не цікавлять. Він погоджується з батьковими настановами, але його метою є здобуття шани, а не військова перемога. Він кілька разів з нетерпінням перепитує батька, як можна цього досягти, коли тому йдеться про інше. Наприклад:

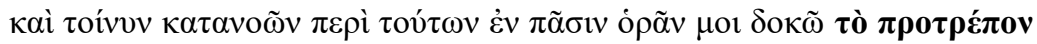

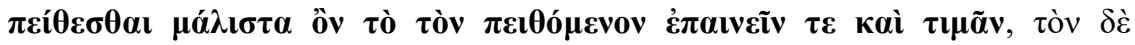

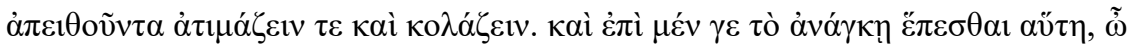

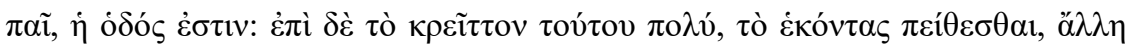

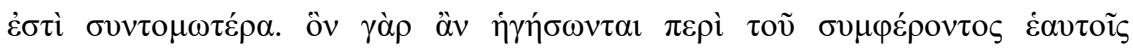

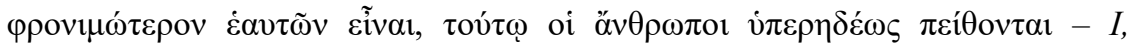
розмірковуючи про все, я вирішив, щчо для покори найбільще необхідно вихваляти й шанувати підлеглого, а непокірного соромити й карати. -I це, сину, - шлях до покори з примусу: набагато певнішим є інший добровільний послух, і цей шлях коротший. Люди-бо з великим задоволенням слухаються того, кого вважають розумнішим у справах їхнього власного блага [Xenophon 1800, I.6.20-21].

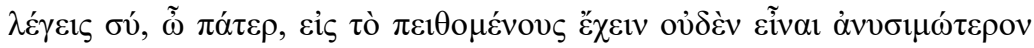

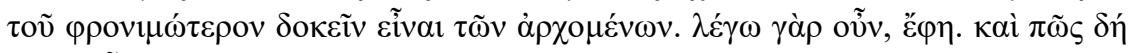

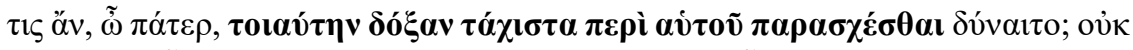

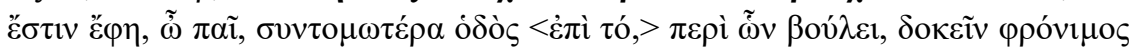

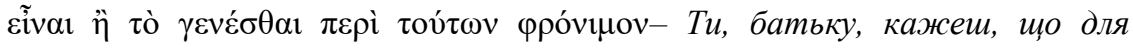
досягнення покори нічого немає вдатнішого, ніж здаватися розумнішим за підлеглих? - Так я й кажу тобі. - А як же, батьку, можна якнайшвидше надбати собі такої слави? - Немає, дитино, коротшого шляху до того, чого ти прагнеш, - здаватися розумнішим, - ніж стати розумним [Xenophon 1800, I.6.22].

Отже, Кіра цікавить, як можна якомога швидше здобути владу над великою кількістю людей. Він щиро вірить, що цього можна домогтися простою похвалою, не докладаючи жодних практичних зусиль. Така його поведінка є константою всього діалогу, який триває до кінця книги. Жодні твердження батька на нього не діють, бо своє питання про “якнайшвидший спосіб” він ставить раз по раз протягом усієї розмови, немовби пропускаючи повз вуха батькові слова.

Такої впевненості в собі й неприхованого усвідомлення власних цілей ми не спостерігаємо за царенком у Мідії. Там він боїться старших і strategija v I knyzi tvoru Ksenofonta "Vyhovannja Kira"] (in Ukrainian) 
намагається діяти “чесно” (пригадаймо епізод, коли він чесно попередив Астіага, що збирається вирушати на полювання, і той йому це, звісно, заборонив [Хеnophon 1800, I.4.13]). Рішучості він сповнюється тільки після зустрічі 3 “коханцем”: вже цитовані тут промова до солдатів і діалог 3 батьком, які є змістом книги після “любовної історії', показують, що сумніви в Кіра відсутні. Остаточне духовне переродження відбувається в царенка в момент, коли йому лестив закоханий мідієць (наратор не випадково говорить про зміну його настрою, точніше про те, яким він був до і після зустрічі), адже погоджуючись на очевидну брехню про “'родича”, Кір мав усвідомлювати, що йому вигідно видавати себе за того, ким він не є.

Мусимо визнати, що момент зустрічі 3 “коханцем” $\epsilon$ перипетією сюжетній лінії I книги “Виховання Кіра'”. Крім того, він ще й збігається 3 моментом золотого перетину (див. термінологічний словничок вище): i3 20 сторінок давньогрецького тексту I книги, набраних 12 кеглем, “більша частина" (до зустрічі Кіра з мідійцем) займає 12 сторінок, а " менша частина” (від зустрічі до кінця книги) - 8 сторінок. 20:12=1,66.., а 12:8=1,5. Це приблизно відповідає пропорціям золотого перетину. Таким чином, кульмінаційність сюжетної вставки про зустріч Кіра із закоханим мідійцем підтверджується.

Проаналізувавши текст I книги “Виховання Кіра" Ксенофонта, можемо зробити наступні висновки:

1. В тексті наявна подвійна структура комунікації - іï розподіл на авторську та нараторську.

2. Метою нараторської комунікації є завуальовування сутності характеру Кіра, утвердження засвоєння ним норм перського виховання.

3. Метою авторської комунікації $є$ викриття справжніх мотивів Кірової поведінки - жаги до багатства та потреби визнання.

4. Вставка про зустріч Кіра із закоханим у нього мідійцем відіграє роль ширми, за якою відбувається ключова для твору безповоротна еволюція у свідомості головного героя.

5. Текстові логічні невідповідності у згаданій вставці та в інших місцях I книги “Виховання Кіра" провокують, у термінах рецептивної естетики, лакуни в прочитанні твору. Пошук заповнення цих лакун дозволяє читачеві вийти на рівень авторської комунікації та виявити 
суперечності в нараторській.

6. Моменти сюжетної перипетії та золотого перетину припадають на згадану вже вставку в [Xenophon 1800, I.4]. Це дозволяє вважати іï кульмінаційним моментом I книги "Виховання Кіра".

7. Наративна стратегія автора полягає в завуальованому зображенні тієї якості Кіра, яку ми б назвали відсутністю виховання. 3 цієї точки зору можемо висловити припущення про те, що проливається нове світло на назву всього твору. Проте це тільки намічена перспектива для подальших досліджень.

\section{Література}

1. Антологіясвітової літературно-критичної думки XX cm., за ред. М. Зубрицької (Львів, Літопис, 1996), 633.

2. Довбищенко, Ф. В. «Комунікативна структура I книги трактату Геродіана «Історія після Марка Аврелія».»Мовні і концептуальні картини світу 1 (52) (2015): 242-253.

3. Довбищенко, Ф. В. «Інформаційний дисонанс рівнів авторської та нараторської комунікації у III книзі «Історії ... » Геродіана.» Studia linguistica 11 (2017): 32-42.

4. Иссерс, О. С. Коммуникативные стратегии и тактики русской речи, 5-е изд. (Москва, Издательство ЛКИ, 2008), 288.

5. Ткачук, О. М. Наратологічний словник (Тернопіль, Астон, 2002), 173.

6. Шмид, В. Нарратология (Москва, Языки славянской культуры, 2003), 312.

7. Aristotelis De Arte Poetica liber.Recognovit brevique adnotatione critica instruxit I. Bywater, Editio altera (Oxonii, E typographeo Clarendoniano, 1911), 66, доступ https://archive.org/stream/aristotelisdeart00aris\#page/n0/mode/2up

8. Genette, G. Discours du récit (Paris, Editions Du Seuil, 1972), 413.

9. Gera, D. L. Xenophon's Cyropaedia: Style, Genre, and Literary Technique (Oxford, Clarendon Press, 1993),360.

10. Mario, L. The Golden Ratio. The Story of PHI, the World's Most Astonishing Number (New York, Broadway Books, 2003), 299.

11. Romberg, B. Studies in the Narrative Technique of the First-Person Novel (Stockholm, 1962), 379.

12. Sage, P. W. «Dying in Style: Xenophon's Ideal Leader and the End of the 'Cyropaedia.» The Classical Journal, vol. 90, no. 2 (1994): 161-174.

13. Tatum, J. Xenophon's Imperial Fiction: On The Education of Cyrus (Princeton University Press, 1989), 301.

14. Whidden, Chr. «The Account of Persia and Cyrus's Persian Education in Xenophon's 'Cyropaedia'.» The Review of Politics, vol. 69, no. 4 (2007): 539-567.

15. Xenophontis Cyropaedia, Graece. Recensuit et interpretatus est, cum notis, 
J. G. Schneider (Lipsiae, 1800), 262, доступ https://www.abebooks.com/booksearch/title/xenophontis-cyropaedia/used/

\section{References}

1. Antologija svitovoi' literaturno-krytychnoi' dumky XX st. [Anthology of the XXth century global literary criticism], za red. M. Zubryc'koi' (L'viv, Litopys, 1996), 633 (in Ukr.).

2. Dovbyshhenko, F. V.«Komunikatyvna struktura I knygy traktatu Gerodiana «Istorija pislja Marka Avrelija» [The communicative structure of the book I of Herodian's Regnum post Marcum].» Movni i konceptual'ni kartyny svitu 1 (52) (2015): 242-253 (in Ukr.).

3. Dovbyshhenko, F. V.«Informacijnyj dysonans rivniv avtors'koi' ta narators'koi' komunikacii' u III knyzi «Istorii' ... » Gerodiana[The discordance between authorial and narratorial communication in the book III of Herodian's Regnum post Marcum].» Studia linguistica 11 (2017): 32-42 (in Ukr).

4. Issers, O. S. Kommunikativnye strategii i taktiki russkoj rechi. [Communicative strategies and tactics of the Russian speech], 5-e izd (Moskva, Izdatel'stvo LKI, 2008), 288 (in Russ.).

5. Tkachuk, O. M. Naratologichnyj slovnyk [Dictionary of narratology] (Ternopil': Aston, 2002), 173 (in Ukr.).

6. Shmid, V. Narratologija [Narrtology] (Moskva,Jazyki slavjanskoj kul'tury, 2003), 312 (in Russ.).

7. Aristotelis.De Arte Poetica liber.Recognovit brevique adnotatione critica instruxit I. Bywater, editio altera (Oxonii, E typographeo Clarendoniano, 1911), 66, access mode: https://archive.org/stream/aristotelisdeart00aris\#page/n0/mode/2up

8. Genette, G. Discours du récit (Paris, Editions Du Seuil, 1972), 413.

9. Gera, D. L. Xenophon's Cyropaedia: Style, Genre, and Literary Technique (Oxford, Clarendon Press, 1993), 360.

10. Mario, L. The Golden Ratio. The Story of PHI, the World's Most Astonishing Number (New York, Broadway Books, 2003), 299.

11. Romberg, B. Studies in the Narrative Technique of the First-Person Novel (Stockholm, 1992), 379.

12. Sage, P. W. «Dying in Style: Xenophon's Ideal Leader and the End of the 'Cyropaedia'.» The Classical Journal, vol. 90, no. 2 (1994): 161-174.

13. Tatum, J. Xenophon's Imperial Fiction: On The Education of Cyrus (Princeton University Press, 1989), 301.

14. Whidden, Chr. «The Account of Persia and Cyrus's Persian Education in Xenophon's 'Cyropaedia'.» The Review of Politics, vol. 69, no. 4 (2007): 539-567.

15. Xenophon. Cyropaedia, Graece. Recensuit et interpretatus est, cum notis, J. G. Schneider (Lipsiae, 1800), 262, access mode: https://www.abebooks.com/booksearch/title/xenophontis-cyropaedia/used/ 
Стаття надійшла до редакиії 13.06.2018 Перевірено на плагіат 20.06.2018 p.

УДК 811.161.2: [81'366+81'373. 611] унікальність $-80.11 \%$

\title{
ДЕРИВАЦІЙНА ПАРАДИГМА ДІЕСЛОВА (НА МАТЕРІАЛІ ХУДОЖНЬОЇ ПРОЗИ Є. ГУЦАЛА)
}

\author{
Заєцьь Валентина Григорівна, v.zaiets@kubg.edu.ua \\ канд. пед. н., доц.
}

Київський університет імені Бориса Грінченка

Розглянуто продуктивність словотвірних типів дієслів. Здійснено аналіз дісслівних формантів художньої прози Є. Гуцала. Підтверджено прикладами унормованість дієслівного словотворення в період 80-х років минулого століття. Показано роль і значення формантів у творенні моделей дієслів. Увагу зосереджено на продуктивних дієслівних афіксах художньої прози. Зафіксовано роль словотворчих формантів для передачі продуктивності діï, процесу, стану. 3'ясовано відтінки значень словотворчих засобів у тексті художньої прози. Визначено роль формантів на позначення початку діï, динамічності діï, завершеності дії. Розкрито роль афіксів на позначення миттєвої неповторюваної дії, якісної характеристики одноразової дї, процесуальності дії. Указано форманти для передавання якісно-оцінної номінації одноразової завершеної дії. Зауважено про рідковживані письменником афікси для експлікації негативної оиінки діï, зворотної дії. Позначено частовживані форманти для продукування словотвірних типів дієслів у художньому тексті. Доведено прикладами властивість дієслова передавати динаміку діі.

Ключові слова: афікс, девербативи, дериваційний потениіал, дієслово, динаміка, номінативність, завершеність дії, лінгвоукраӥністика, парадигма, прочесуальність, словотворчий засіб, формант.

\section{ДЕРИВАЦИОННАЯ ПАРАДИГМА ГЛАГОЛА (НА МАТЕРИАЛЕ ХУДОЖЕСТВЕННОЙ ПРОЗЫ Е. ГУЦАЛО)}

\section{Заеи Валентина Григорьевна, v.zaiets@kubg.edu.ua} канд. пед. н., доц.

Киевский университет имени Бориса Гринченко

Рассмотрена производительность словообразовательных типов глаголов. Осуществлен анализ глагольных формантов художественной прозы Е. Гуиало. Подтверждена примерами унормированность глагольного словообразования в период 80-х годов прочлого века. Показана роль и значение формантов в создании

Actual Problems of Linguistics $\overline{\text { [Aktual'niproblemymovoznavstva] }}$ (C) Zaiets V.[Zajec'V.],v.zaiets@kubg.edu.ua

The Derivational Paradigm of the Verb (on the Material of E. Hutsalo Fiction Prose) [Deryvacijna paradygma dijeslova (na materiali hudozhn'oi' prozy Je. Gucala)] (in Ukrainian) 
моделей глаголов. Внимание сосредоточено на производительных глагольньх аффиксах художественного стиля Е.Гуцало. Зафиксирована роль словообразовательных формантов для передачи производительности действия, прочесса, состояния. Выяснены оттенки значений словообразовательных средств в тексте художественной прозы. Определена роль формантов для обозначения начала действия, динамичности действия, завершенности действия. Раскрыта роль аффиксов для обозначения мгновенного действия, качественной характеристики одноразового действия, прочессуальности действия. Указань форманты для обозначения качественно-оченочной номинации одноразового завершенного действия. Отмечены редко употребляемые аффиксы для экспликации негативной оиенки воздействия, обратной силы. Обозначены часто употребляемые форманты для производных типов глаголов в художественном тексте. Доказана органичность глагола в передаче динамики прочессов в прозачческм произведении.

Ключевые слова: аффикс, девербативы, деривационный потенциал, глагол, динамика, номинативность, завершенность действия, лингвоукраинистика, парадигма, прочессуальность, словообразовательное средство, формант.

\title{
THE DERIVATIONAL PARADIGM OF THE VERB (ON THE MATERIAL OF E. HUTSALO FICTION PROSE)
}

\author{
Zaiets Valentyna, v.zaiets@kubg.edu.ua \\ PHD, Associate Professor, \\ Boris Grinchenko University of Kyiv
}

The productivity of word-formation types of the verbs has been examined. The analysis of verbal prose formants (usedin Y. Hutsalo's prose) has been made. The examples confirmed the normative way of verbal wordformation during the period of 80-s years of the previous century. The role and the meaning of formants in verbal models' formation have been shown. The attention has been focused on the verbal affixes in fiction. The role of word-formation formants for conveying the productivity of action, process, and state has been revealed. The connotative meanings of word-formation means in the text of art prose has been clarified. The role of formant for designation of the beginning of action, dynamism of action, completeness of action has been defined. The role of affixes for designation of non-repeating immediate action, qualitative characteristic of onetime action, procedurality of action has been proven. The formants used for transferring of the qualitative nomination of one-time complete action have been specified. The seldom used by the author affixes, which were used for the explication of a negative evaluation of action reaction effect have been looked upon. Often used formants for producing the wordformation types of verbs in the fiction text have been designated. The possibility of a verb 
to transfer the dynamics of action has been proved with the examples.

Key words: affix, derivative, derivative potential, verb, dynamics, normativity, completeness of action, Ukrainian linguistic studies, paradigm, procedurality, wordformation means, formant.

Дослідження словотвірної структури дієслів у художній прозі Є. Гуцала $є$ актуальним, позаяк допомагає розкрити продуктивні типи моделювання вторинних дериватів, виявити виражальні можливості твірних основ, афіксів для маркування в тексті статичних і динамічних ознак тощо. Цілком погоджуємося 3 думкою Т. Коць, що у 80-х роках минулого століття мова художньої прози ілюструвала унормоване словотворення. На думку дослідниці, “завдяки мовному чуттю письменників, у літературній мові закріпилися і стилістично нейтральні, і стилістично забарвлені, експресивнооцінні мовні засоби” [Коць 2011, с. 67]. Як відомо, в 70-80-і роки минулого століття літературні критики пильнували тенденції у “виваженому словесному мистецтві”, додали “словникові холодини”, відкидали “штучні або застарілі” лексеми як “наслідок ерозії. Зауважимо, що проза Є. Гуцала була неодноразово об’єктом літературної критики, наводилися безпідставні аргументи, приклади, що "Гуцало не Платон” [Українська мова у XX сторіччі: історія лінгвоциду: Док. і матеріали 2005, с. 301; с. 303-304].

Водночас зауважимо, що українська мова вищеназваного періоду переживала процеси, які особливо позначалися на лексичному складі й вели до змін на всіх їі рівнях, зокрема й словотвірному. Принагідно згадати, що в літературі 80-х років минулого століття дієслівний корпус не зазнав консервативних утисків, а навпаки окреслював збереження автором художнього тексту питомо українських моделей словотворення, що позначилося на особливостях ідіостилю Є.Гуцала. У прозовому творі дієслівний масив посідає чільне місце, що обумовлено "граматичним значенням динамічного процесу (дії або стану)" [Вступ до мовознавства : підручник 2016, с. 227]. Граматичні характеристики дієслова доповнюють та розкривають словотворчі засоби, що допомагають маркувати дію, іiі становлення, тривання, розгортання тощо.

В україністиці різноструктурні моделі дієслівного словотворення стали предметом низки досліджень. К. Городенська, М. Кравченко розкрили ознаки структурної організації відіменних дієслів, згрупували за словотворчою базою, підтвердили прикладами їх наповнюваність [Городенська, Кравченко 1981]. 
Відомо, що стилістичні функції дієслова закладені природою граматичних категорій, зокрема частин мови. Саме засоби дериватології підкреслюють приналежність дієслів до певного стилю, про що наголошують сучасні дослідники Л. Мацько, О. Мацько, О.Сидоренко i зауважують, зокрема, що стилістична сила дієслова "міститься в їх семантиці і в розгорнутій системі морфологічних форм", завдяки яким "художній текст ніби рухається" [Мацько 2003, с. 45-46]. О. Пономарів також розглядає природу дієслова як “один із засобів відтворення динаміки, тому художній та розмовний стилі широко послуговуються цією частиною мови” [Пономарів 2000, с. 157].

Сучасні мовознавчі праці різнопланово розглядають словотвірний потенціал дієслів на матеріалі художньої прози. У виконаних студіях автори вдаються до описового аналізу експресивних мовних одиниць, щоб окреслити відмінності в семантиці, яка досягається твірною основою та словотворчими засобами художнього стилю української мови. Зокрема, досліджено словотвірну семантику відсубстантивних дієслів, зазначено “похідні, утворені суфіксальним і конфіксальним способом словотворення" [Лагута 2003]. І. Овчиннікова типологізувала дієслівні значення, функціонально-семантичні показники, носії ознаки часової співвіднесеності й фазовості [Овчиннікова 2012, с. 106-111]. Розкрито стилістичне навантаження дієслів у художньому дискурсі, що посилюється словотворчими афіксами [Заєць 2015, с. 17-19].

Прикметно, що україністика має чисельні розвідки дієслівної парадигматики на засадах основоцентричного підходу [Грещук 1995]. Керуючись вищевказаним принципом, О. Кушлик визначила групи словотворчих засобів для моделювання семантичних відтінків, указала на “глибину семантичних позицій словотвірної парадигми” [Кушлик 2014, с. 63]. Для нашої розвідки важливими $є$ позиції дослідниці щодо словотвірної структури вторинних дієслів, яку “формують три словотвірні зони субстантивна, вербальна й ад’єктивна” [Кушлик 2016, с. 181-182].

Як бачимо, різноструктурні похідні дієслова ілюструють внутрішньомовні резерви української дериваційної традиції, надають додаткових забарвлень дієслівному слововислову в художній прозі.

Отже, на часі дослідження словотвірної структури дієслів у рамках художнього стилю періоду “жорсткого консерватизму”, експлікація зразків моделей дієслівного слововислову. Зауважимо, що структура вторинних 
дієслів є виражальним засобом для маркування відтінків, якісних змін стану, під дією зовнішніх чи внутрішніх чинників. У сучасній лінгвоукраїністиці дериваційна структура моделей дієслів на матеріалі прози Є. Гуцала вивчена недостатньо. Художня проза для дітей має широкі можливості для ілюстрації різноструктурних типів похідних дієслів, надає підгрунтя для відстеження семантики мотивувальної основи та стилістичного навантаження афіксів.

Об’єктом дослідження є словотвірна структура дієслів у художній прозі Є. Гуцала. Предметом дослідження $\epsilon$ особливості стилістичного навантаження дієслівних формантів для маркування семантичних відтінків у художньому стилі. Метою роботи є дослідження словотвірних дієслівних моделей у художніх текстах Є. Гуцала, встановлення ролі словотвірних афіксів у їх функціонуванні. Завдання розвідки - проаналізувати словотвірну структуру дієслів, показати ступінь продуктивності різнопланових мотивувальних основ, афіксів та їх вплив на семантичні відтінки в тексті художньої прози для дітей.

Матеріалом нашого дослідження слугували близько 900 лексичних одиниць дієслів із різним конотативним значенням, відібраних методом суцільної вибірки зі збірки оповідань для дітей Є. Гуцала «Полювання 3 гончим псом». Обстежений матеріал творів письменника ілюструє здатність використовувати внутрішньомовний потенціал для продукування лексем на позначення дії, поведінки героїв, їх психічного та фізичного стану, мотивувальною основою, дериваційними засобами дієслів передавати семантичні відтінки змін якостей, стану, процесу.

Аналіз корпусу дієслів дитячої прози Є.Гуцала дає можливість описати різноструктурні словотвірні моделі, узагальнити кількісні обрахунки продукованих вторинних одиниць, розглянути семантику твірних лексем.

Особливістю прозового художнього тексту для дітей $\epsilon$ висока продуктивність дієслів, що, окрім конкретної фізичні дії, передають зміни стану, становлення предмета, якісні зміни, вияв міжсуб’єктних відношень, ставлення до кого-небудь, діяльність органів чуття тощо. Беручи до уваги основоцентричний підхід, зауважимо, що в аналізованих творах помічено значну кількість похідних різноструктурних дериватів.

В аналізованій прозі для дітей помічено різні моделі дериватівперфективів, що маркують результативність дії, а точніше - iї завершальний етап. Наповнюваність цієї групи становить до 300 одиниць, що мають у 
похідних моделях префікси для маркування додаткових відтінків значень, на зразок: в-/y- - напрямок дії (влипнув, влився, влучив, всоталась, упірнув); ви-- звільнення від чогось, протилежний напрямок дії (витурила, випростався); з-/с- - однократний вияв дії, напрямок руху (звинуватили, зготувала, здивувався, здригнулася, зреагувала, зруйнувала, зодягнулась, зринути, сполохала, сповільнював); за- - початок дії, щуо має часове $i$ просторове значення (загальмував, заголубіла, заломились, замаскували, запозичкувала, заплутався, засумували); на- - додатковість чогось (навідувалась, накульгував, нарвала, народжувались,); о-/оді- - дія навколо чогось (озвалась, осмикнув, одірвав); пере- - повторення дії (перехрестився); при- - зближення, приєднання (пригальмував, пригорнув, примирився, пришпилив); по-/по+роз/по+c- - рух у певному напрямку, коротка повторювана дія (повірити, постукала, подався, повитикалися, попилюжсив, порозбігалися, пороз '̈̈жджалися, посковзнулась); роз-+про- - поширення векторів дії (розгнівалася, розвернувся, роззирнулась, розплющила, розгорнула). Пор.: А от від перенісся біліла ясна стьожка, й ия стьожка білої шерсті, перетнувши лоб і голову, розросталася, розпросторювалася в пухнастий білий загривок [Гуцало 1980, 141]; Все ладен роздарувати, - бубонить вдова Бандуриста і зникає в хаті [Гуцало 1980, с. 153]; по+за(позапікалися); по+зі(позіщулювались). Пор.: Ви з Сайорою посхоплювалися з піску й через кущі гайнули за лисеням [Гуцало 1980, с. 59]; Виглядає ріжок тернової хустини, яку він колись подарував матері на жіноче свято [Гуцало 1980, с. 152]; Хороби ми вже полікували, оклигує собачка [Гуцало 1980, с. 155].

Окрему групу дієслів-перфективів в аналізованих текстах оповідань утворюють деривати (близько 130 одиниць), в структурі яких афікс -ну-, зокрема для характеристики дій, що сприймаються зором: 1) миттєва неповторювана дія, що завершилася в момент мовлення, на зразок: блимнули, ворухнулись, гайнув, гулькнув, гойднулась, діткнулась; кивнула, клачнув, ковтнув, повернувся, увімкнув, обернулась, сіпнулися, спіткнувся, тицьнувся, сполохнула; 2) якісна оцінка одноразової здійсненої в момент мовлення дії, на зразок: зиркнула, порснув, спалахнув. Пор.: Рожева лопатка язика здригнулась, клацнули ікла [Гуцало 1980, с. 76]; Собака ковтнув шматочок ковбаси, клачнувши іклами [Гуцало 1980, с. 77]; I- дивно - той і справді, либонь, знався на гуморі, бо повернув до нас морду і крутнув хвостом [Гуцало 1980, с. 82]; 3) різкий перехід з одного стану до іншого, на зразок: здригнувся, одвернула, (C)Заєць В. Г. [Заец В. Г.], v.zaiets@kubg.edu.ua Дериваційна парадигма дієслова (на матеріалі художньої прози С. Гуцала) [Деривационная парадигма глагола (на материале художественной прозы Е. Гуцало)] (Українською / На укр. яз) 
підморгнув, підштовхнув; спіткнувся; 4) набуття нового стану,на зразок: тріснула, тхнула; 5) якісну характеристику окресленої дії, на зразок: осмикнув, осягнути, зазирнути, позіхнув, струснула, підштовхнув, шпигнула. Пор.: I на безмежному гіллі неправдоподібно яскраво спалахнуло безліч кетягів [Гуцало 1980, с. 25]; Від нього відреклись, живцем здихати змусили, а він не здатен осягнути людської жорстокості, відплачує за жорстокість незрадливою любов'ю [Гуцало 1980, с. 84]; Собака торкався грудьми ї̈ колін і намагався зазирнути в обличчя [Гуцало 1980, с. 86]; Брови в неї здригнулись ображено, а кутики повних вуст сіпнулись [Гуцало 1980, с. 88]; Собака знову здригнувся, знову підвів морду $i$, потремтівии віхтем язика поміж тинків фосфоричних ікол, позіхнув [Гуцало 1980, с. 90]; Й Петро Зеленюк схлипнув од розчулення шепеляво так, із посвистом крізь зиілені зуби [Гуцало 1980, с. 286]; Наказали скинути кожух, валянки, шапку [Гуцало 1980, с. 111]; Ксаверій Якубов усміхнувся своєюзвичайною усмішкоюй подався до хліва [Гуцало 1980, с. 143]; Мисливського собаку за законом треба повернути власникові або в міліцію повідомляти про знахідку [Гуцало 1980, с. 150]; O, тепер у Найди є товариш! вигукнув, помітивии в Катриних руках великого ведмедя [Гуцало 1980, с. 164]; ... Катря стала зграбно здригатись на старий-престарий клен, щуоб із його верика зазирнути на сусідське подвір'я [Гуцало 1980, с. 166]; I скрушно, й досадливо крутнув головою в баранячих кільцях в 'юнкого волосся [Гуцало 1980, c. 166]. Як бачимо, що структура похідних перфективів змінюється за умови вираження характеристики окресленої дії суфіксом -ну-, відповідно це ілюструють не лише префікси $8 u$-, з-/c-, за-, $o$-, nid-, no-, $y$-, але й постфікси -ся, $-c b$.

Твірна основа вторинних дієслів виступає типологізувальним чинником, зокрема дозволяє в межах аналізованих оповідань відзначити високу продуктивність відзвукових дериватів (близько 130 одиниць) для маркування різнопланових дій людини, тваринного світу, довкілля поєднанням звуконаслідувальної твірної основи з афіксами, що несуть різне семантичне навантаження, на зразок: 1) префікс за- виступає виразником початку дії звуку, або його стадії (забубонів, задзвонив, застогнав, затупотіло, затьохкав, затріщзавзахрущуав, зашарудів, зашелестів). Пор.: Зовсім поряд зарипіли шпииі, забряжчали щиттки, задеренчав багажник, затріскотів ланцюжок, сідло застогнало на пружинах, - $і$ з цьього брязкання виразно пробився голосок дзвінка [Гуцало 1980, с. 149]; 2) суфікс -нупередає миттєвість, короткотривалість 
відзвукової дії (брязнув, зойкнув, вигукнула, ойкнула, охнув, свиснув). Пор.: Сторчак склав губи курячим гузенщем і свиснув [Гуцало 1980, с. 205]; 3) конфікси ви- ... -y-, віס- ... -y-, по- ... -y-, nо- ... -yвa- ілюструють повторювану через певний проміжок часу дію (вибамкує, відгукується, поклаиують, подзенькують, посвистував, постукував, скрикував, хрумкотів, похрумкує, похрускує). Пор.: А дзвінок вибамкував на велосипеді, на якому їхав Ксаверій Якубов [Гуцало 1980, с. 149]; I раптом долинув до слуху слабенький писк, наче миші попискували в соломі, й ви здогадались: там ще є лисенята, вони бігають, бавляться [Гуцало 1980, с. 59].

Бестіальні дієслова маркують звуки, джерелом яких $є$ виключно представники тваринного світу, на зразок: заскімлив, зверескують, муркотіла, рохкає, кувікають, кляминув, скрикнув. Пор.: Собака жалібно заскімлив [Гуцало 1980, с. 142]; Далі витяг уперед шию, кляминув зубами $i$, світячи білими іклами, став жувати повільно, болісно й так само болісно та судорожно ковтнув їжу [Гуцало 1980, с. 144]; Травник розпачливо скрикнув - із чорного дзьобика ті скрики вилітали як безсилі погрози [Гуцало 1980, с. 5]; Рожева лопатка язика здригнулась, клацнули ікла [Гуцало 1980, с. 76]. Тоді як предметні дієслова-ономатопи експлікують звуки, продуковані під впливом зовнішніх чинників, на зразок: рипнули, порипували. Пор.: Куртка й штани на мовчазному й гордочолому Ігорі порипували так, як порипує зимовий сніг у великий мороз [Гуцало 1980, с. 163]; Сурма йшла по вулииі так само, як іще недавно йшли гітара та барабан, $i$ вона то зойкнула, то схлипувала, то раптом пронизливо скрикувала [Гуцало 1980, с. 97].

Зауважимо, що в межах досліджуваної прози відстежуємо міжкласові взаємопереходи гомональних дієслів (“позначають звуки, що видає людина”), бестіальних (“звуки, що видає тварина, птах, плазуни”) до предметних (ті, що “позначають звуки, утворювані за допомогою предметів”) і навпаки, що значно посилює оригінальність ідіолекту письменника, на зразок: Велосипед зойкнув, охнув, застогнав, забубонів, балакучий дзвіночок затьохкав, затріщав - і Ксаверій Якубов поїхав [Гуцало 1980, с. 149]. Помічено, що текст попереднього речення обов'язково має конкретизатори для уточнення звукової приналежності, на зразок: (дзвінок велосипеда) То щебетав, то тьохкав, то цвірінчав, то посвистував, як іволга, то підпадьомкав, то мало совою не ухкав [Гуцало 1980, с. 142]; Зовсім поряд зарипіли шпиці, забряжччали щитки, задеренчав багажник, затріскотів ланџюжок, сідло (С)аєць В. Г. [Заец В. Г.], v.zaiets@kubg.edu.ua Дериваційна парадигма дієслова (на матеріалі художньої прози Є. Гуцала) [Деривационная парадигма глагола (на материале художественной прозы Е. Гуцало)] (Українською / На укр. яз) 
застогнало на пружинах, - $i$ з цзього брязкання виразно пробився голосок дзвінка [Гуцало 1980, с. 149]; Новітуфлі свинячої шкіри кувікають під ї̈ дорідним тілом так, як би кувікало поросятко [Гуцало 1980, с. 152]; Мабуть, коли дебелий чоловік [Хома] обіймає та ичілує свою Лукію, то ї̈ туге тіло аж похрускує, аж похрумкує від його волячої ніжності [Гуцало 1980, с. 200].

Оригінальністю позначені в ідіолекті С. Гуцала відзвукові лексеми, наділені авторською характеристикою дії, зокрема емоційно-оцінний відтінок виражає твірна основа, що вказує на подібність звучання через його порівняння, на зразок: буркнув, вибамкує, гамселить, гарикатимуть, забубоніли, загорлав, залементувала, пробурчав, промимрив, тарабанився.Пор.: Сурма йшла по вулиці так само, як іщуе недавно йшли гітара та барабан, $і$ вона то зойкнула, то схлипувала, то раптом пронизливо скрикувала [Гуцало 1980, с.97]; - Все ладен роздарувати, бубонить вдова бандуриста і зникає в хаті [Гуцало 1980, с. 153]; $\ddot{I} і$ [Маріїн] грудний оксамитовий голос задзвонив, як дзвоник, веселою скоромовкою [Гуцало 1980, с. 177]; Ген майнула знайома дівоча постать, i Bacb-Bacь загорлав радісно [Гуцало 1980, с. 191]; Студент будзагону зареготав так несподівано, щзо шофер спитав уражено [Гуцало 1980, с. 193].

Окремий корпус дієслів відрізняється словотвірною структурою продукованих лексем (близько 140 одиниць), що мають високу дериваційну спроможність виражати, зокрема відприкметниковою основою, різні семантичні відтінки дії (інхоативи, есиви, каузативи). Кількісно переважають інхоативи (до 60 лексем), що мають семантику “набувати ознаки, названої твірним прикметником або ставати таким, як визначено твірною основою”, на зразок: блідішало, вилітнилась, доспіла, заголубіла, захмелів, здуріла, зголоднів, засумували, зачерствів, заяскравіли, змарніло, накульгував, німувала, побілішало, пожовтіло, позеленіла, поночіло, посивіла, посвіжішало, побадьорішав, подебелішав, полум'яніли, скляніла, сполохала, сполотніла, спохмурнів, струхлявів, потвердішала, почервоніло, чорніють. Пор.: Тліють $і$ горять, жаріють і вогневіють, $і$ димлять, $і$ начебто чадять десь у лісовій гущавині [Гуцало 1980, с. 27]. Обстежений корпус дієслів доводить схильність автора до вибору твірної прикметникової основи, сполученою з формантом $\boldsymbol{i}$ для номінування процесуальності дії, становлення ознаки, зокрема спричиненої певними якісними змінами, на зразок: посивіла, заголубіла, потемніло, засинів. Пор.: Він і досі не втратив свого дитячого 
дару червоніти без видимої причини[Гуцало 1980, с. 256]; Висолопив язика, важко дихає, очі почервоніли [Гуцало 1980, с. 143]; Під гайком паслась череда худоби, і серед корів яскраво пломеніли телята густої вогнистої масті [Гуцало 1980, с. 114]; А ви, кумо, вилітнились, маєте здоров'я, то й добре, я теж мала здоров'я, як була молода [Гуцало 1980, с. 237]; Але тільки уявляє, як Леся захворіла, як лежить у ліжку, як змарніло й пожовтіло ї̈ обличчя $<$ _..>[Гуцало 1980, с. 151]; Прикипівши поглядом до Ігоря, напарниияспершу зблідла, далі почервоніла, далі знову зблідла [Гуцало 1980, с. 164].

Окрему малочисельну групу дериватів (до 50 одиниць) становлять дієслова-есиви (мають семантику “виявляти ознаку, названу твірним прикметником”), на зразок: біліло, біліли, голубіла, горбився, одбуяла, зоріли, заяскріло, зеленіли, кривавились, німувала, пломеніли, поменшало, помилувався, полум'яніли, рожевіє, свіжішав, світилася, скляніла, сивіла, синіли, темніла, червоніти. Як показує обстежений корпус дієслів-есивів, у структурі дериватів переважає формант -i-, зокремав ідіолектіписьменника, маркує розгортання необмеженої в часі дії. Пор.: Пройхали біля ставків, над якими зеленіли верби [Гуцало 1980, с. 112]; По видолинку біліли хати в садках, мерехтіла вода в ставках [Гуцало 1980, с. 113]; Це був ящик із-під посилки, темніла обкришена сургучева печать, а також адреса - область, район, село [Гуцало 1980, с. 99]; Клен за вікном гойднувся, вир його важкої зелені від вітру наче розпався, й знову у вільному просторі заяскріло небо, й вибухнуло літнє сонще, обливши мої руки і письмовий стіл фосфоричним світлом [Гуцало 1980, 98]; Віднісши листи до контори колгоспу, де голубіла поштова скринька, Жерелиия взяв у сільмазі сиру, печива й подався назад [Гуцало 1980, с. 173]; Людей на вуличі й по обійстях поменшало [Гуцало 1980, с. 102].

Корпус каузативних дієслів (мають семантику “наділяти ознакою, названою твірним прикметником або робити таким, як визначено твірною основою") має до 30 лексичних одиниць для ілюстрації зміни якості предмета засобами конфіксального, конфіксального-постфіксального, на зразок: замирюватися, загострював, змилосерджується, осмілився, омолоджував, остуджувала, переінакшилося, поменшало, посвіжішав, поскупиться, потвердішала, підкріплювалися, поширювали, розженюватися, усуспільнював. Пор.: Мені трудно повірити в ї щирість, бо я зачерствів, погас, звітрився < ...> [Гуцало 1980, с. 182]; Я навіть не хотів запитати в себе: хто ж вона така, Кривенька Галинка, щоб раптом усе (С)аєць В. Г. [Заец В. Г.], v.zaiets@kubg.edu.ua Дериваційна парадигма дієслова (на матеріалі художньої прози С. Гуцала) [Деривационная парадигма глагола (на материале художественной прозы Е. Гуцало)] (Українською / На укр. яз) 
переінакшилося, мені в цей день?[Гуцало 1980, с. 103]; Видавались безплотними, риси їхні звітрились так, як звітрюється камінь-піщаник [Гуцало 1980, с. 102]; Ти ж мене з усіма в селі пересварив, тепер муситиму замирюватись [Гуцало 1980, с. 252]. Як бачимо, виразником тієї чи іншої ознаки слугують конфікси, на зразок: $o-\ldots-u-, o-\ldots-y в a-$, пере- ..-u-, за- ...-i-, за-... -юва-, по-... -а-, по-... -іши-а-, у-... -юва-, по- ... -юва-.

Обстежений корпус похідних дієслів показує продуктивність словотвірних моделей, що мають твірну іменникову основу та афікси -ува-/ -юва- для маркування граматичного значення недоконаного виду (“ставати тим, чим названо твірну основу”), на зразок: агітувати, витійствував, іронізував, жартував, лікував, міркувала, реставрувати, рятувати, спалахував, сторожував, пащекувала, програмувати, пульсували, товаришували, торжествував. Пор.: дозрівали ягоди на вишнях $і$ черешнях; плантації буряків наче фонтанували соковитою, жилавою гичкою; на водяній скалиі тоненької річечки плавали білі гуси і жовті гусенята [Гуцало 1980,с. 46-47]; Материнський інстинкт такий сильний, що однаково, кого годувати: своїх дітей чи чужих [Гуцало 1980, с. 155]; Він клав иеглину до й витійствував [Гуцало 1980, с. 191].

Особливістю ідіолекту письменника $Є$. Гуцала $\epsilon$ чисельна група відсубстантивних дієслів (близько 200 одиниць), що мають словотвірну семантику «виконувати дію (рухатися), позначати процес чи перебувати в стані, зміст яких визначається асоціативно-метафоричною співвіднесеністю 3 предметом, названим мотивувальним іменником», на зразок: вигніздилися, виправдовувався, женихатись, завихрюються, замогоричити, запозичкувала, засекретити, зсудомилася, катапультуються, купчились, наструнював, опромінився, розсекретили, порозповзалися, продзьобаєщся, усуспільнював, скособочилася, пригальмував, фосфоресиіюють тощо. Основу оригінальності слововислову автора становить метафоричність, яку передають асоціації, закладені іменниковою основою. Пор.: Зір заткався пеленою сліз, їхній туман тремтів - i тремтіли біла палата, кущі бузку та акацій за вікном, ліжка з хворими [Гуцало 1980, с. 127-128]; А от перенісся біліла ясна стьожка, й ия стьожка білої шерсті, перетнувши лоб і голову, розросталася, розпросторювалася в пухнастий білий загривок [Гуцало 1980, с. 141]; Цямрини криниці, побурівши й позеленівши, скособочилися [Гуцало 1980, с. 105]; Все ладен роздарувати, - бубонить вдова Бандуриста $і$ зникає 
в хаті [Гуцало 1980, с. 153].

Наведені приклади різноструктурних моделей вторинних відсубстантивних дієслів доводять, що мотивувальна основа іменника номінує дію, стан, тоді як окремі конфікси можуть конкретизувати маркування різної семантики дії, стану:1) динамічність виконуваної дії (зі-/3 + -юва- + -л-), на зразок: Грім то буркотів добродушно, а то враз озивався з таким запалом, що мимоволі яблуні й груші в садку зіщулювались, $i$ по картоплі, піднімаючи ї̈ блідий ивіт, перебігав переляк [Гуцало 1980, с. 15]; $<\ldots>$ при ході підошви зблискували ще новенькими фірмовими знаками, щяо золотавим сяйвом не могли не стривожити уяву спостережливих сільських жителів [Гуцало 1980, с. 15]; 2) початок дії (за- + -ува- + -л-), на зразок:Того самого дня на клені під моӥм вікном забрунькувало перше листячко [Гуцало 1980, с. 42]; Коли заграли “білий” танець, дівчата стали запрошувати хлопиів [Гуцало 1980, с. 188]; 3) коротку повторювану дію (по-+ -юва- (ува)+ -л-), на зразок: Ви з Сайорою посхоплювалися з піску й через кущі гайнули за лисеням [Гуцало 1980, с. 59]; Виглядає ріжок тернової хустини, яку він колись подарував матері на жіноче свято [Гуцало 1980, с. 152]; I раптом долинув до слуху слабенький писк, наче миші попискували в соломі, й ви здогадались: там ще є лисенята, вони чи бігають, чи бавляться [Гуцало 1980, с. 59]; Хороби ми вже полікували, оклигує собачка [Гуцало 1980, с. 155]; 4) поширення векторів дії (роз-+про--юва-+ -л- або роз-+юва-+ (ти), на зразок: А от від перенісся біліла ясна стьожка, й ия стьожка білої шерсті, перетнувши лоб $і$ голову, розросталася, розпросторювалася в пухнастий білий загривок [Гуцало 1980, с. 141]; 5) багатократність дії зізначенням робити “по-іншому”, “наново”, “через когось чи щзось” (пере-+ -y; пере-+ ува(-юва)+л), на зразок: переблискує, переборювали, перепурхували, перешіптувалися. Пор.:Де вони перечікували грозу, де ховались від погроз грому і блискавок? [Гуцало 1980, с. 19]; Через ту лапку та ще пошкоджене крило Кривенька Галинка змалечку не навчилась літати, а тільки ледь-ледь перепурхувала в повітрі, сідаючи то на ворину, то на кущ, то на коворот кринииі [Гуцало 1980, с. 100].

Серед дієслівних утворень з суфіксом і відстежуємо денотати, зокрема характерні розмовному стилю, що маркують характеристику дії, набуття стану. Пор.: Міг би погомоніти з ним, багато довідався б [Гуцало 1980, с. 113]; Олянка, ощасливлена тим чужим отетерінням, спинилась на хвильку 
погомоніти [Гуцало 1980, с. 164]; < .. > озвалась дівчина, явно не дозволяючи собі отетеріти [Гуцало 1980, с. 186]; В коморі постелили сіно, кожух, подушку і вклали Кирила, аби виспався, Кирило відбрикувався, проте заснув одразу [Гуцало 1980, с. 186].

Отже, словотвірні структури дієслів у прозі Є. Гуцала ілюструють здатність формантів впливати на стилістичне навантаження художнього тексту. Авторське моделювання форм дієслів тісно залежить від афіксів, що експлікують у художньому творі якісно-оцінне конотативне значення. Творчий доробок письменника потребує усебічного грунтовного студіювання дериваційних процесів.

\section{Література:}

1. Бабакова, О. В. «Семантична структура та функціонування дієслів звучання.»Автореф. дис. канд. філол. наук, Запоріжжя, 2007.

2. Вступ до мовознавства: підручник, І. О. Голубовська, С. М. Лучканин, В. Ф. Чемес та ін.; за ред І. О. Голубовської (Київ, ВЦ «Академія», 2016), 320.

3. Гуцало, Є. П. Полювання з гончим псом: Оповідання (Київ, Рад. Письменник, 1980), 288.

4. Городенська, К. Г., Кравченко, М. В. Словотвірна структура слова (відіменні деривати) (Київ, Наук. думка, 1981), 198.

5. Грещук, В. Украйнський відприкметниковий словотвір (Івано-Франківськ, Плай, 1995), 208.

6. Заєць, В. Г.«Стилістичні функції словотворчих засобів дієслів у художньому дискурсі Марка Вовчка.» Науковий вісник Міжнародного гуманітарного університету, Серія Філологія 19, т. 2 (2015): 17-19.

7. Коць, Т. А. Літературна норма у функціонально-стильовій і структурній парадигмі (Київ, Логос, 2010), 303.

8. Кушлик, О. «Континуум словотвірних значень дериватів вербальної зони типової словотвірної парадигми відсубстантивних дієслів із семантикою “обробляти об’єкт названою твірним іменником речовиною”.» Рідний край 1(2014): 63-69.

9. Кушлик, О. «Словотвірна парадигматика відсубстантивних дієслів зі словотвірним значенням “перебувати в психічному стані, названому твірною основою”.» Актуальні питання гуманітарних наук 15 (2016): 180-188.

10. Лагута, Т. М. «Семантико-типологічна характеристика відсубстантивних дієслів сучасної української мови.» Автореф. дис. канд. філол. наук, Харків, 2003.

11. Мацько, Л. І. та ін. Стилістика украӥнської мови: підручник (Київ, Вища шк., 2003), 462.

12. Овчиннікова, I. І. «Лексико-семантична група дієслів інтелектуальної дії в українській літературній мові.» Філологічні студї 9 (2013): 329-334.

13. Овчиннікова, І. І. «Часова локалізованість і фазовість як таксономічні ознаки дієслів дії в українській мові.» Система і структура східнослов'янських мов 6 (2012): 
106-112.

14. Плющ, М. Я. Граматика української мови. Морфеміка. Словотвір. Морфологія: підручник (Київ, Слово, 2010), 327.

15. Пономарів, О. Д.Стилістика сучасної української мови: підручник, 3-те вид., перероб. і доповн. (Тернопіль, Навчальна книга - Богдан, 2000), 248.

16. Українська мова у XX сторіччі: історія лінгвоциду: Док. $і$ матеріали,упоряд.: Л. Масенко та ін. (Київ, Вид. дім «Києво-Могилянська акад.», 2005), 399.

\section{References:}

1. Babakova, O. V. «Semantichna struktura ta funkcionuvannja diesliv zvuchannja.» Avtoref. dis. kand. filol. nauk, Zaporizhzhja, 2007.

2. Vstup do movoznavstva: pidruchnuk, I. O. Holubovs'ka, S. M. Luchkanin, V. F. Chemes ta in.; za red I. O. Holubovska (Kyi'v, VZ Akakdemija), 320.

3. Huzalo, Je. P. Poluvanna z honchum psom (Kyi'v, 1980), 288.

4. Gorodens'ka, K. G., Kravchenko, M. V. Slovotvirna struktura slova (vidimenni derivati) (Kyi'v, Nauk. Dumka, 1981), 198.

5. Greshhuk, V. i dr. Ukrajins'kij vidprikmetnikovij slovotvir (Ivano-Frankivs'k, Plaj, 1995), 208.

6. Zaiets, V. G. «Stilistichni funkziji slovotvorchih zasobiv dijesliv u hudozhn'omu diskursi Marka Vovchka.» Naukovij visnik Mizhnarodnogo gumanitarnogo universitetu, Serija Filologija 19 (2015): 17-19.

7. Kots, T. A. Literaturna norma u funktsionalno-stylovii i strukturnii paradyhmi (Kyi'v, Lohos, 2010), 303.

8. Kushlik, O. «Kontinuum slovotvirnih znachen' derivativ verbal'noji zonu tipovoji slovotvirnoji paradigmi vidsubstantivnih dijesliv iz semantikoju "obrobljati objekt nazvanoju tvirnim imennikom rechovinoju".» Ridnij kraj 1 (2014): 63-69.

9. Kushlik, O. «Slovotvirna paradigmatika vidsubstantivnih dijesliv zi slovotvirnim znachennjam “perebuvati v psihichnomu stani, nazvanomu tvirnoju osnovoju”.» Aktual'ni pitannja gumanitarnih nauk 15 (2016): 180-188.

10. Laguta, T. M. «Semantiko-tipologichna harakteristika vidsubstantivnih diesliv suchasnoï ukraïns'koï movi.» Avtoref. dis. kand. filol. nauk, Harkiv, 2003.

11. Mac'ko, L. I. i dr. Stilistika ukrä̈n'koï movi: pidruchnik (Kyi'v, Vishha shk, 2003), 462.

12. Ovchinnikova, I. I. «Leksiko-semantichna grupa dijesliv intelektual'noji diji v ukrajins'kij literaturnij movi.» Filologichni studiï 9 (2013): 329-334.

13. Ovchinnikova, I. I. «Chasova lokalizovanist' i fazovist' jak taksonomichni oznaki diesliv diji v ukrajins'kij movi.» Sistema i struktura shidnoslovjans'kih mov 6 (2012): 106-112.

14. Pljushh, M. Ja. Gramatika ukraïns'koï movi. Morfemika. Slovotvir. Morfologija: pidruchnik (Kyi'v, Slovo, 2010), 327.

15. Ponomariv, O. D. Kultura slova: Movnostylistychni porady: navch. posibnyk (Kyi'v, Lybid, 1999), 240.

16. Ukrainska mova u XX storichchi: istoriia linhvotsydu: Dok. i materialy, uporiad.: L. Masenko ta in.- Vyd. dim «Kyievo-Mohylianska akad.», 2005), 399.

Актуальні проблеми мовознавства [Актуальные проблемы языкознания]

(С)аєць В. Г. [Заец В. Г.], v.zaiets@kubg.edu.ua

Дериваційна парадигма дієслова (на матеріалі художньої прози С. Гуцала) [Деривационная парадигма глагола (на материале художественной прозы Е. Гуцало)] (Українською / На укр. яз) 


\title{
ДИСКУРС ТА ФУНКЦІОНАЛЬНИЙ СТИЛЬ: ПРОБЛЕМА СПІВВІДНОШЕННЯ
}

\section{Ковальова Олена Костянтинівна, chelena2076@gmail.com}

\author{
к. філол.наук, доцент
}

Дніпровський національний університет ім. О. Гончара

Статтю присвячено проблемі співвідношення категорій дискурсу та функиіонального стилю. Увагу до иієї проблеми обумовлено, з одного боку, зростанням популярності дискурсивного аналізу та терміна дискурс $i$, з іншого боку, тим фактом, що функиіональний стиль залишається однією з ключових категорій сучасної східноєвропейської стилістики. Окреслено ключові теоретичні засади концепиій дискурсу та функиіонального стилю; їх спільні риси; критерії їх розмежування.

Для теоретичного зіставлення обох категорій залучено концепиї дискурсу М. Фуко, франиузької та німещько-австрійської шкіл аналізу дискурсу, Н. Д. Арутюнової, Т. ван Дейка, а також розуміння стилю В. В. Виноградовим, М. Н. Кожиною. На думку сучасних дослідників, дискурс та функиіональний стиль належать до суміжних лінгвістичних дисииплін та мають близькі ознаки. Ключовою ознакою називають екстралінгвістичні фактори, які прямо визначають спещифіку дискурсу та функціонального стилю. Водночас дослідники рішуче розмежовують дискурс та функиіональний стиль, визнаючи складність проблеми виокремлення критеріїв для такого розмежування. Розрізнення обох категорій здійснюється на основі онтологічного критерію: дискурс трактується через поняття "дискурсивна формаиія", стиль - через "форму суспільної свідомості". Відповідно спеиіалісти доходять висновку про різнопорядковість, різноприродність феноменів дискурсу та функиіонального стилю. Констатується самодостатність кожної з конщепиій та наголошується на необхідності їх спільного застосування для глибшого лінгвістичного аналізу тексту.

Поряд з ичи, співвідношення дискурсу та стилю розглядається на основі текстоцентричної моделі дискурсу. Аргументується думка про певну ієрархічну підпорядкованість методів стилістики дискурс-аналізу. Говориться про “вбудовування" предмета стилістики у предмет аналізу дискурсу, яке сприяе інтердисииплінарному збагаченню: аналіз дискурсу набуває власне 
“лінгвостилістичного наповнення”, а стилістика реалізується в руслі чітко окреслених функиіональних параметрів дискурсу.

Ключові слова: дискурс, функціональний стиль, дискурсивна формація, форма суспільної свідомості, текст.

\section{ДИСКУРС И ФУНКЦИОНАЛЬНЫЙ СТИЛЬ: ПРОБЛЕМА СООТНОШЕНИЯ}

\section{Ковалева Елена Константиновна, chelena2076@gmail.com}

к. филол. наук, доцент

Днепровский национальный университет им. О. Гончара

Статья посвящуена проблеме соотношения категорий дискурса и функционального стиля в трактовках современных специилистов. Внимание к этой проблеме обусловлено, $c$ одной сторонь, возрастающей популярностью дискурсивного анализа и самого термина дискурс, и, с другой стороны, тем фактом, что функииональный стиль остается одной из ключевых категорий современной восточноевропейской лингвистики. Bыделены ключевые теоретические положения концепций дискурса и функционального стиля; общие черты дискурса и функиионального стиля; критерии их разделения.

Для теоретического сопоставления названных категорий привлечень концепции дискурса М. Фуко, франщузской и немецко-австрийской школ анализа дискурса, Н.Д. Арутюновой, Т. ван Дейка, а также понимание стиля В. В. Виноградовым, М.Н. Кожиной. По мнению современных исследователей, дискурс и функииональный стиль относятся $\kappa$ смежным лингвистическим дисииплинам и имеют общие признаки. Основным таким признаком называют экстралингвистические факторы, которые прямо определяют специфику дискурса и функиионального стиля. В то же время, исследователи решительно размежовывают дискурс и функииональный стиль, признавая сложность проблемь ux разделения. Разграничение категорий осуществляется на основе онтологического критерия: дискурс трактуется через понятие "дискурсивная формация”, стиль - через “форму общественного сознания”. Соответственно, ученые приходят $к$ выводу о разнородности, разнопорядковости, разноприродности феноменов дискурса и функционального стиля. Констатируется самодостаточность каждой из кониепичй и акцентируется необходимость их совместного применения для более глубокого лингистического анализа текста.

Соотношение дискурса и функционального стиля рассматривается также

Актуальні проблеми мовознавства [Актуальные проблемы языкознания] СКовальова О. К.[Ковалева Е. К.],chelena2076@gmail.com

Дискурс та функціональний стиль: проблема співвідношення [Дискурс и функциональный стиль: проблема соотношения] (Українською / На укр. яз) 
на основе текстоцентрической модели дискурса. Аргументируется тезис об определенной иерархической подчиненности методов стилистики дискурс-анализу. Говорится о “встраивании” предмета стилистики в предмет анализа дискурса, которое способствует интердисииплинарному обогащению: в этом случае анализ дискурса приобретает собственно “линвостилистическое наполнение”, а стилистика реализуется в русле четко обозначенных функииональных параметров дискурса.

Ключевые слова: дискурс, функииональный стиль, дискурсивная формация, форма общественного сознания, текст.

\title{
DISCOURSE AND FUNCTIONAL STYLE: THE PROBLEM OF THE CORRELATION
}

\author{
Kovalova O., chelena2076@gmail.com \\ $\mathrm{PhD}$, Associate Professor, \\ Oles Honchar National University of Dnipro
}

The article is devoted to the problem of the correlation of the categories of discourse and functional style in modern specialists interpretations. Attention to this problem is caused, on the one hand, by the growing popularity of the discursive analysis and the very term discourse, and, on the other hand, by the fact, that functional style remains one of the important categories in Eastern Europe linguistics. The key theories of discourse and functional style; the common features of discourse and functional style; the criteria for their separation have been singled out.

The concepts of M. Foucault's discourse, French and German-Austrian discourse analysis, schools of N. Arutyunova, T. van Dijk, as well as the understanding of the style of $V$. V. Vinogradov and M. N. Kozhina have been involved for the theoretical comparison of the above-mentioned categories. According to modern researchers, discourse and functional style relate to the neighbouring linguistic disciplines and have common features. One of them is extralinguistic factor, which directly determine the specificity of discourse and functional style. At the same time, researchers put borders for discourse and functional style, recognizing the complexity of the problem of their separation. The differentiation of the categories is carried out by means of the ontological criterion: the discourse is interpreted via the concept of "discursive formation", while style is interpreted via "the form of public consciousness". Accordingly, scholars come to the conclusion about the diversity of structure and nature of the discourse and functional style. The importance of each concept is stated and the neccessity of their joint application for a deeper linguistic analysis of the text is emphasized.

The correlation of the discourse and functional style is also considered on the basis of the textocentric model of discourse. The thesis about a certain hierarchical subordination of the

Actual Problems of Linguistics [A $\overline{\text { ktual'ni problemy movoznavstva] }}$

(C) KovalovaO. [Koval'ova O.], chelena2076@gmail.com

Discourse and Functional Style: the Problem of the Correlation [Dyskurs ta funkcional'nyj styl': problema spivvidnoshennja] (in Ukrainian) 
methods of stylistics and discourse-analysis is argued. It is said about the "embedding" of the stylistics into the subject of discourse analysis, which promotes interdisciplinary enrichment: in this case, the discourse analysis acquires the proper "linguostylistic" content, and stylistics is realized in the frames of functional parameters of the discourse.

Key words: discourse, functional style, discursive formation, form of public consciousness, text.

Вступ. На початку XXI століття констатується певна неузгодженість у практичному вживанні термінів дискурс (Д) та функціональний стиль (ФС). Цей факт підтверджує поява низки робіт, присвячених проблемі співвідношення Д та ФС, які мають теоретичний [Кожина 2008, Чернявская 2009, Орлова 2013, Негрышев 2014] та оглядовий [Крисанова 2016] характер. Висловлюються різні думки: про непрямі відносини між теорією Д та ФС (Н. Д. Арутюнова), про спільні та відокремлюючі ознаки ФС та Д (М. Н. Кожина), про неможливість зведення Д до стилю (Ю. С. Степанов), про суміжність, паралельне існування, але не тотожність Д та ФС (О.В.Орлова), про Д як поле практичної діяльності та стиль як теоретичний, естетичний, мовленнєвий конструкт (Н. І. Клушина). Попри різноманітність інтерпретацій дослідники сходяться в одному: вони рішуче розмежовують Д та ФС, визнаючи при цьому складність проблеми виокремлення критеріїв для такого розмежування.

Стійку цікавість до цього питання може бути пояснено, окрім популярності, власне, самого терміна дискурс, двома причинами. По-перше, теорія дискурсу та дискурсивний аналіз виявились привнесеними у вітчизняну лінгвістику і нашарувались на вже існуючу, достатньо усталену теоретикометодологічну матрицю функціональної стилістики. По-друге, спільними для обох вчень $є$ мовленнєвий підхід, орієнтованість на екстралінгвістичні фактори текстотворення, що М. Н. Кожина формулює як “вивчення процесів мовлення iз урахуванням різноманітних екстралінгвістичних умов i факторів його реалізації' [Кожина 2008, с. 191], а А. А. Негришев екстралінгвістичні фактори іменує “дискурсивним контекстом” [Негришев 2014, с. 151]. Поряд з цим Д та ФС мають принципові відмінності, різні теоретико-методологічні основи, порізному членують комунікативний простір.

Отже постає питання визначення специфіки співвідношення понять Д та ФС. Рефлексії у цьому напрямку ускладнюються, 3 одного боку, 
мультиконтекстним та мультизначним використанням терміна дискурс. 3 іншого боку, усвідомленням сучасними вченими того факту, що під впливом, зокрема, стрімкого розвитку масових комунікацій “система функціональних стилів зазнає перебудови, змінюються самі стилі та відношення між ними" [Гайда 2015, с. 18].

Серед робіт вітчизняних лінгвістів з цієї проблеми маємо назвати статтю I. С. Шевченко, у якій дискурсивно орієнтований та функціональностилістичний підходи розглянуто на конкретному прикладі мовленнєвого жанру екскурсії. Досліднця відзначає сфокусованість аналізу Д на аспекті динаміки, а функціонально-стилістичного аналізу - на аспекті статики, правомірно вбачаючи в цьому ключову їх відмінність [Шевченко 2012, с. 135]. У статті загальнооглядового характеру за авторством Т. А. Крисанова зазначається, що функціональна стилістика та дискурсивний аналіз вивчають різні аспекти тексту як продукту мовленнєвої діяльності людини [Крисанова 2016, с. 189]. Вона також дотримується думки, що відмінність ФС та Д можна окреслити опозицією понять статика - динаміка. ФС вивчає композицію тексту, принципи його побудови та вербальне наповнення, тобто вивчає текст у статиці, як готовий продукт, результат мовленнєвої діяльності. Дискурсивний аналіз пояснює текст у зв'язку із соціально-історичними аспектами його творення, тобто у динаміці. Такі висновки є цілком логічними, особливо якщо пригадати класичне визначення дискурсу Н.Д. Арутюновою як "тексту, взятого у подієвому аспекті” [Арутюнова 1990, с. 136].

Проте проблема Д та ФС $є$ набагато складнішою i потребує систематизації існуючих підходів. Адже визначити теоретико-методологічне співвідношення Д та ФС можливо, перш за все, чітко окресливши самі поняття Д та ФС. І якщо ФС має достатньо чіткі критерії визначення, то щодо Д про однозначність або будь-які сталі трактування говорити не доводиться. Роботи сучасних дослідників демонструють різноманітність підходів, яка потребує осмислення: М. Н. Кожина [Кожина 2008], В. С. Чернявська [Чернявская 2006, 2009, 2011], О. В. Орлова [Орлова 2013] демонструють, що ФС та Д функціонують у різних вимірах комунікативного простору, оскільки мають відмінні онтологічні основи. А. А. Негришев говорить про “вбудовування” предмета стилістики у предмет аналізу Д [Негришев 2014].

Мета і завдання дослідження. Як бачимо, на даному етапі постає необхідність більш детального огляду концепцій щодо співвідношення Д та 
ФС, що й обумовлює мету даної статті. Реалізація мети передбачає виконання кількох завдань, зокрема окреслення: 1) ключових теоретичних засад понять Д та ФС; 2) спільних рис Д та ФС; 3) критеріїв їх розмежування, запропонованих спеціалістами.

Виклад основного матеріалу дослідження. П. Серіо, спираючись на Д. Менгено (D. Maingueneau), наводить вісім значень терміна Д, які функціонують у лінгвістиці. О. О. Селіванова вважає найбільш вживаними 3 них чотири значення. Зупинимось на них детальніше.

1) Розуміння Д, запропоноване 3. Харрісом у 1952 році. Засновник трансформаційного та дистрибутивного аналізу, 3. Харріс розглядав Д на основі еквівалентності між фразами та ланцюжками фраз, як надфразову одиницю у контексті інших одиниць та пов'язаної з ними ситуації.

2) Подієво-ситуаційний аспект Д, який став результатом розробки Т. ван Дейком концепції комунікативної природи тексту. За Т. ван Дейком, Д є складною єдністю мовної форми, значення та дії - того, що можна назвати комунікативною подією або комунікативним актом. Важливими складовими такого акту є мовець, слухач, їхні особистісні та соціальні характеристики [Дейк 2000, с. 121-122].

3) Найбільш поширене, як зазначає О. О. Селіванова, значення Д у сучасній лінгвістичній літературі походить від положення французької семіотичної традиції про ототожнення Д з мовленням, переважно усним. У рамках цього підходу Д співвідноситься 3 комунікативним процесом, накладається на співвідношення мови та мовлення і розглядається як строго прив'язана до мовленнєвого акту подія, яка моделює та регулює мовні норми та протограматичні форми мовної свідомості, переводячи його у мовлення.

4) Д як тип дискурсивної практики. У цьому аспекті дискурс реалізує комунікативно-прагматичні аспекти мовленнєвої поведінки, що має місце у певній соціальній сфері з визначеним набором перемінних: соціальні норми, відносини, ролі, конвенції і т. д. [Селіванова 2004, с. 36-41].

Не менш важливо назвати популярне серед сучасних дослідників визначення Н. Д. Арутюнової: “Д - це мовлення, занурене у життя”, “зв’язний текст у сукупності 3 екстралінгвістичними - прагматичними, соціокультурними, психологічними та іншими факторами; текст, взятий у подієвому аспекті” [Арутюнова 1990, с. 136].

Для розуміння специфіки співвідношення понять Д та ФС важливими 
стали концепції Д, напрацьовані авторитетними школами аналізу Д французькою та німецько-австрійською. I тут потрібно акцентувати, що для обох шкіл лінгвістичний аспект дослідження Д не був пріоритетним. Французька школа (П. Серіо, М. Пеше, Ж. Отьє-Ревю, Ж. Гійом, Р. Робен) спирається на філософські концепції М. Фуко, інтерпретації марксизму А. Альтюссера, психоаналіз Ж. Лакана. Ключовими критеріями розуміння Д для представників цієї школи стали ідеологія та інституційність. При цьому поняття ідеології визначається П. Серіо не як організована система ідей, а як “будь-який семіотичний факт, що інтерпретується у світлі соціальних інтересів i в якому набувають законності соціальні значимості в їхній історичній обумовленості" [Серіо 1999, с. 20-21]. Тексти або висловлювання розглядаються як продукти ідеологічної та психічної практики, вони $\epsilon$ культурно, соціально, ідеологічно обумовленими. Аналіз Д в цій школі постає як аналіз тексту, виконаний в інституційних рамках.

До німецько-австрійської школи аналізу Д відносять У. Маaса, Ю. Лінка, Ю. Хабермаса. Розвиваючи ідеї М. Фуко, У. Маас вважає, що будьякий текст $є$ частиною та вираженням суспільної практики. Д виступає як відповідна мовна формація відносно суспільної практики, визначеної соціально та історично. Ключовим для У. Мааса та інших представників школи є поняття системності мовних явищ, спільних принципів їх застосування, яке стоїть за конкретним Д.

Рефлексії М. Фуко, французької та німецько-австрійської шкіл поєднує те, що вони “розглядають дискурси як особливі мовні формації, які корелюють 3 тією чи іншою сферою суспільної практики, людського пізнання та комунікаціі” [Чернявская 2009, с. 142].

Поняття ФС досліджене сучасними спеціалістами достатньо детально. Основу трактування ФС складають, як відомо, ідеї Ш. Баллі, вчених Празької лінгвістичної школи, напрацювання В. В. Виноградова, які істотно вплинули на подальше вивчення ФС цілим рядом дослідників - М.Н. Кожиною, I. В. Арнольд, Г. Я. Солганіком, Ю. С. Степановим, К. А. Долініним, 3. І. Хованською, Н. П. Потоцькою, В. Г. Кузнецовим та багатьма іншими, а у сучасній вітчизняній стилістиці - С. Я. Єрмоленко, Л. І. Мацько.

Більшість існуючих потрактувань ФС спираються на дефініцію, надану В.В.Виноградовим у 1955 році: “Стиль - це суспільно усвідомлена та функціонально обумовлена, внутрішньо об’єднана сукупність прийомів 
вживання, відбору та сполучення засобів мовленнєвого спілкування у сфері тієї чи іншої суспільної, загальнонаціональної мови, співвідносна з іншими такими ж засобами вираження, які слугують для інших цілей, виконують інші функції у мовленнєвій суспільній практиці даного народу” [Виноградов 1955, с. 73]. У наведеному визначенні “мовленнєва суспільна практика народу” постулюється як фактор, який визначає специфіку певного стилю. Виноградівську трактовку конкретизовано, розвинено та доповнено М. Н. Кожиною, яка вводить поняття “форма свідомості” у якості критерію формування ФС: “Своєрідний характер мовлення того чи іншого соціального його різновиду, який відповідає певній сфері суспільної діяльності та співвідносній з нею формі свідомості, і який створюється особливостями функціонування у цій сфері мовних засобів та специфічної мовленнєвої організації” [Кожина 2008, с. 91].

Додамо також визначення Ю.С. Степанова: “ФС - це історично утворена, усвідомлена суспільством підсистема всередині системи загальнонародної мови, закріплена за тими чи іншими ситуаціями спілкування (типовими мовленнєвими ситуаціями) та схарактеризована набором засобів...вираження і прихованим за ними принципом відбору цих засобів із загальнонаціональної мови” [Степанов 1965, с. 218].

3. I. Хованська дефініює ФС через поняття “сфера та умови спілкування”: “Специфічний функціональний прояв загальнонародної мови, соціально усталений, типізований спосіб вираження, пристосований до відповідної сфери та умов спілкування” [Хованская 1984, с. 190].

Не звертаючись до інших визначень ФС, можна констатувати такий ключовий момент: специфіка, своєрідність ФС обумовлюється екстралінгвістичними факторами, які прямо впливають на його формування. Дослідники виділяють серію таких факторів: форма суспільної свідомості, тип мислення, типові особливості змісту (М.Н. Кожина); сфера суспільнополітичної діяльності, тип мовомислення (Л. І. Мацько); сфера суспільної діяльності, колективно усвідомлені ситуації (С. Я. Єрмоленко); ситуації спілкування (Ю.С. Степанов); тема i сфера вживання, макроконтекст (Н. П. Потоцька); тема і сфера вживання, умови спілкування, задача мовлення (Г. Я. Солганік); умови спілкування у різних сферах людської діяльності (І. В. Арнольд); фактор соціальної універсальності, за якого у певну сферу комунікації залучаються усі носїі мови (Т. О. Воронцова).

Ряд дослідників працює над класифікацією екстралінгвістичних 
факторів. Виокремлюються два типи таких факторів: комунікативні та стилетворчі. 3. І. Хованська виділяе кілька комунікативних факторів: комунікативна сфера, соціально-культурний тип учасників комунікації, ситуативна специфіка мовленнєвої комунікації, типізована цільова настанова мовленнєвого спілкування [Хованская 1984, 191-192].

Систематизоване та цілеспрямоване вивчення стилетворчих факторів здійснюється чеськими та словацькими стилістами, починаючи 3 празьких класиків Б. Гавранека та В. Матезіуса, ідеї яких сприйняли i розвинули Ф. Травничек, А. Сдлічка, К. Гаузенблас, М. Елінек та ін. Напрацьовано цілісну концепцію, яка вважається класичною і полягає у розрізненні об'єктивних та суб'єктивних стилетворчих факторів. До об'єктивних факторів відносять: функцію стилю; ситуацію та обставини спілкування; учасників - їх число, стосунки, спосіб контакту, ступінь орієнтування на адресата; “форму” мовлення та пов'язані 3 цим фактори - діалогічність/монологічність та підготовленість / непідготовленість; "характер" офіційний/неофіційний; залежність мовлення від ситуації / вивільнення 3 ситуації; тема [Гоффманнова 2015, с. 52]. При зіставленні типологій комунікативних та стилетворчих факторів виявляються спільні фактори, зокрема, учасники та ситуації комунікації. В інших аспектах наведені типології доповнюють одна одну, створюють комплекс екстралінгвістичних факторів формування ФС. До цього необхідно додати, що дослідники підкреслюють методологічну важливість одночасного виявлення екстра- та інтралінгвістичних факторів текстотворення, адже тільки їх сукупність здатна розкрити повною мірою специфіку ФС.

Попри певну усталеність теоретичних уявлень про поняття ФС, спеціалістами констатується дискусійність окремих його аспектів. Зокрема, на тлі перегляду концепції екстралінгвістичних факторів, спірним вважається питання ефективності поєднання стилетворчих факторів 3 комунікативними, а також $з$ комунікативною моделлю, схемою акта комунікації, наприклад, 3 моделлю Р. Якобсона, від якої походить розрізнення шести основних функцій мови [Гоффманнова 2015, с. 53]. Продовжує обговорюватись питання кількості $\Phi С$, зокрема, чи мають окремо виділятись художній, рекламний та церковнорелігійний стилі.

Ще однією проблемою є поділ ФС на підстилі або жанри. Складність такої класифікації існує, по-перше, за рахунок різноманітності пропонованих 
критеріїв. По-друге, за рахунок виникнення нових, так званих гібридних жанрів, які поєднують ознаки не одного, а різних стилів і виникнення яких пов'язують зі стрімким розвитком Інтернету. Для вирішення цієї проблеми висувається перспективна ідея - застосувати до ФС модель поля А. В. Бондарко. М. Н. Кожина вживає термін "польова структура функціонального стилю” [Кожина 2008, 126], О. О. Селіванова “функціональне поле стилю” [Селиванова 2004, 105]. Згідно з такою моделлю ядром поля ФС постають тексти 3 набором традиційних для того чи іншого стилю цілей та мовленнєвих засобів, а на периферії розташовуються гібридні жанри та тексти, які використовують засоби інших стилів. Тобто “стиль “побудовано” за принципом поля, а самі ці стилі взаємодіють та впливають один на одного переважно у периферійній області” [Кожина 2008, с. 125-126]. Наприклад, на перетині ділового та наукового мовлення, тобто на периферії кожного з цих стилів може знаходитись текст інструкції як жанру.

Отже, стає очевидним, що досвід та результати вивчення ФС певним чином корелюе 3 напрацюваннями у сфері аналізу Д. Комплекс екстралінвістичних факторів, які впливають на ФС, $\epsilon$ актуальним і для формування типів Д, принаймні, якщо говорити про концепції Д Т. ван Дейка, Н. Д. Арутюнової, М. Фуко, французької та німецько-австрійської шкіл аналізу Д.

М. Н. Кожина виділяє кілька спільних параметральних ознак ФС та Д 3 уточненням, що ці ознаки мають узагальнюючий характер: 1) мовленнєвознавчий підхід обох теорій до мовних явищ, за якого основним предметом дослідження є мовлення у його різновидах; 2) екстралінгвістичні фактори, які обумовлюють і принципово визначають спосіб мовного втілення конкретного мовленнєвого висловлювання; 3) принцип системності використання мовних засобів. Системність визначається як взаємозв'язок різнорівневих мовних засобів, застосування яких диктується екстралінгвістичними факторами; 4) Тексти (письмові та усні) як результат мовленнєвої (дискурсивної) діяльності і одночасно як матеріал дослідження; 5) міждисциплінарний метод аналізу.

Ключовим, визначальним внеском М. Н. Кожиної у розуміння специфіки ФС стало іiі твердження щодо форми суспільної свідомості як головного екстралінгвістичного фактору формування ФС. Поняття форми суспільної свідомості М. Н. Кожина трактує на основі синтезу марксизму та 
класичної філологіі: як різноманітні форми відображення у свідомості людей об'єктивного світу і суспільного буття, що виникають у процесі практичної діяльності : правосвідомість, наука, політична ідеологія, мистецтво, релігія [Кожина 2008, с. 192]. Тобто вчена пов'язує форму суспільної свідомості зі сферою людської діяльності, що у формулюванні В. Є. Чернявської визначено як “фундаментальні онтологічно задані форми пізнання та діяльності” [Чернявская 2011, с.94]. Відповідно до форм суспільної свідомості М. Н. Кожина виокремлює офіційно-діловий, науковий, публіцистичний, художній та релігійний ФС і додає, що основою розмовно-побутового стилю слугує буденна свідомість у сфері побутових відносин та спілкування.

Принципове, родове розрізнення ФС та Д М. Н. Кожина проводить на основі онтологічного критерію: якщо ФС пояснюється нею через поняття форми суспільної свідомості, то Д-через поняття мовної формації. У розумінні мовної формації М.Н. Кожина використовує відомий термін М.Фуко “дискурсивна формація”, який, в свою чергу, сягає марксистського поняття суспільно-економічної формації. У роботі “Археологія знання” М. Фуко визначає дискурсивну формацію на основі філософських критеріїв: “У тому випадку, коли між об'єктами, типами висловлювань, поняттями та тематичними виборами ми могли б визначити закономірність (régularité) (порядок, кореляції, позиції та дії, перетворення), ми домовимося говорити, що маємо справу з дискурсивною формацією” [Фуко 2004, 93]. Дискурсивна формація, за М. Фуко, частіше за все відповідає не одному жанру, а поєднує кілька жанрів. "Різноманітність жанрів дискурсної формації не є випадковим виникненням за наявності ядра зі стійким змістом, вона сприяє визначенню його характеристики" [Cеріо 1999, с. 28-29]. За М. Н. Кожиною, термін дискурсна формація відображає зв'язок з ідеологією та взагалі ідеологізований підхід до об’єкта дослідження. Специфіку Д М. Н. Кожина пояснює так: “Д -це особливі мовні формації, які корелюють з будь-якою сферою людської практики, пізнання та комунікації' [Кожина 2008, с. 196]. Вчена слушно вказує на невирішеність проблеми структурування та взаємодії дискурсивних формацій у французькому підході до аналізу Д.

Відмінністю онтологічних основ генезису ФС та Д як форм мовленнєвої реалізації сфер людської свідомості пояснюється питання систематизації об’єктів ФС та Д. Теорія ФС розробила достатньо струнку загальну класифікацію свого об’єкта на стилі, підстилі, жанри і т. д. Теорія Д пропонує 
окремі класифікації типів Д за різними критеріями.

Логічним видається міркування О. В. Орлової, у якому вона підсумовує та розвиває положення М.Н. Кожиної: ФС набуває таких властивостей суспільної свідомості, як непряма соціально-історична обумовленість, тенденція до інваріантності мовленнєвих маніфестацій, типізація множинності окремих суспільних практик в об'єктивно обмежену кількість форм суспільної свідомості. Д характеризується фокусованою прив'язкою до певної суспільної практики, прямою соціально-історичною обумовленістю, рухливістю, динамічністю, процесуальністю, ситуативністю, тенденцією до множинної варіативності мовленнєвих маніфестацій [Орлова 2013, с. 21-22].

Вагомий внесок у прояснення проблеми співвідношення ФС та Д зроблено В. С. Чернявською [Чернявская 2006, 2009, 2011]. У своїх теоретичних рефлексіях дослідниця спирається на потрактування Д М. Фуко, французькою та німецькою школами аналізу Д, а також на напрацювання М.Н.Кожиної, які істотно доповнюе та розвиває. В. Є. Чернявська зосереджується на двох аспектах питання: відмінностях методологій аналізу Д і ФС та принципах членування комунікативного простору обома підходами.

Як і М.Н. Кожина, В.С. Чернявська бачить особливе значення естралінгвістичних факторів для дискурсивного та стилістичного аналізу. Проте самі ці фактори, як показує дослідниця, у кожного з підходів свої, що і визначає їх відмінність. Для стилістичного аналізу такими факторами $є$ форма суспільної свідомості, види діяльності, сфера, мета і задачі комунікації. Для дискурсивного аналізу - психологічні, політичні, національно-культурні, прагматичні фактори.

У питанні принципів систематизації комунікативного простору В. Є. Чернявська логічно вбачає фундаментальну відмінність ФС від Д. Форма суспільної свідомості як базовий критерій класифікації ФС приводить до висновку про те, що кількість ФС не може бути безкінечною, адже типові соціально значимі сфери спілкування та діяльності представляють собою глобальні сегменти людської практики.

Дискурсивному підходу властивий інший, більш деталізований принцип поділу дискурсивного простору. В. С. Чернявська акцентує увагу на тому, що на відміну від ФС, у цьому принципі відсутня ієрархічна співвіднесеність внутрішніх елементів. М. Н. Кожина називає це інституційним, ідеологічним принципом, говорячи, наприклад, про Д 
фашизму або про Д, який відповідає соціальним інститутам (церква, армія і т. д.). В. Є. Чернявська вдається до конкретизації і визначає тематичний та інтенціональний принципи поділу. На їі думку, класифікація текстів на типи Д має бути на основі приналежності цих текстів до конкретної сфери людської практики, галузі знання, періоду часу. “Д- це сукупність тематично спільних текстів, кожний з яких сприймається та ідентифікується (!) як мовний корелят певної соціально-культурної практики" [Чернявская 2011, с. 93]. Тому типів Д або дискурсивних практик може бути безкінечно багато: публіцистичний Д, політичний, медичний, юридичний, рекламний і т. д. Або, наприклад, у науковому дискурсі можливо виокремити Д хімії, Д органічної хімії, Д генетики і т. д.

Розуміння Д у цьому сенсі найбільш концентровано бачимо у такому визначенні В. С. Чернявської: “Комунікативна подія як інтегративна сукупність певних комунікативних актів, результатом якої $\epsilon$ змістовотематична єдність багатьох текстів” [Чернявская 2009, с. 147].

У підсумку В. С. Чернявська доходить висновку про самодостатність концепцій ФС і Д та наголошує на необхідності застосування кожного з них як засобу лінгвістичного аналізу тексту. ФС не може заперечуватись сучасними дискурсивними підходами і зберігає самодостатню значимість як одиниця членування текстового континууму. Одночасно Д як особливий модус опису мовної діяльності є значимим як одиниця операційного аналізу, яка додає деталізації у наші уявлення про комунікативну практику [Чернявская 2011, с. 94].

Іншу форму співвідношення ФС та Д визначає А. А. Негришев, авторитетний дослідник у галузі аналізу Д. У своєму розумінні Д він спирається на відоме трактування Н. Д. Арутюнової: “Мовлення, яке розглядається як цілеспрямована соціальна дія, як компонент, що бере участь у взаємодії людей та механізмів їх свідомості (когнітивних процесах)" [Арутюнова, с. 136]. Її розуміння Д є близьким до класичної концепції критичного дискурс-аналізу Т. ван Дейка. За ван Дейком, Д - це “складне комунікативне явище, яке включає в себе соціальний контекст, що дає уявлення як про учасників комунікації (та їх характеристики), так і про процеси виробництва та сприйняття повідомлення” [Дейк 2000, с. 113].

А. А. Негришев оперує термінами стилістика тексту та дискурсологія. Він відмічає співпадіння об’єкта дослідження обох 
дисциплін, логічно вбачаючи таким об'єктом текст. Проте предмети дослідження лінгвостилістики та дискурсології є, за А. А. Негришевим, різними: для стилістики - це структурно-семантичні особливості тексту, актуалізатором яких виступає дискурсивний контекст; для дискурсологіїявища у тексті, які пов'язують його з Д та виявляють похідність тексту від дискурсивно-комунікативного середовища [Негришев 2014, с. 151]. Іншими словами, стилістика застосовує індуктивний метод аналізу, який передбачає рух від тексту до контексту, а дискурсологія - дедуктивний метод, для якого важливим є рух від контексту до тексту.

А. А. Негришев пояснює співвідношення стилістики та дискурсології на основі напрацьованої ним текстоцентричної моделі Д. Він розглядає текст як занурений у дискурсивне середовище, тобто у контекст, який розуміє як сукупність параметрів або “стандартів" мовленнєвої діяльності, що визначають принципи породження/сприйняття тексту та його структуру.

За А. А. Негришевим, текст має чотири ключових аспекти дослідження: інтенціональний (що розкриває зв'язок автор - текст), референціальний (зв'язок дійсність - текст), когнітивний (текст реципієнт) та мовний (текст - мова). Кожний з аспектів є об’єктом вивчення певного лінгвістичного напрямку: інтенціональний аспект належить до сфери лінгвістичної прагматики, референціальний - до теорії референції, когнітивний - до когнітивної лінгвістики, i, нарешті, мовний - до лінгвостилістики.

Особливе значення у цьому комплексному підході А. А. Негришев надає саме лінгвостилістиці. Можливості іiі методологічного аналізу дозволяють найповніше дослідити текст як лінгвістичне явище i, водночас, виявити у ньому структури та механізми, які пов'язують його 3 дискурсивним середовищем, тобто контекстом. Виявлення таких структур та механізмів дослідник вбачає метою комплексного дискурсивностилістичного аналізу. Основними принципами такого аналізу є: 1) аналіз дискурсивного виміру тексту через виявлення “сил Д”, які впливають на його структуру (напрям дискурсивне середовище - текст), тобто дедуктивний принцип; 2) аналіз самої структури тексту 3 точки зору взаємодії у ньому власне стилістичних засобів мови 3 дискурсивними параметрами мовленнєво-текстової діяльності (напрямок текст - 
дискурсивне середовище), тобто індуктивний принцип. Ключовою ланкою дискурсивно-стилістичного аналізу А. А. Негришев вважає традиційний стилістичний аналіз тексту. Розширення стилістичного аналізу за рахунок категорій макротекстової структури (у розумінні Т. ван Дейка) та дискурсивної домінанти тексту забезпечує вихід на дискурсивний рівень.

Таким чином, А. А. Негришев говорить, по суті, про “вбудовування” предмета стилістики у предмет аналізу Д. I підсумовує, що таке “вбудовування" сприяє інтердисциплінарному збагаченню: аналіз Д набуває власне “лінгвостилістичного наповнення”, а стилістика реалізується у руслі чітко окреслених функціональних параметрів Д [Негришев 2014, с. 160].

Висновки та перспективи подальших розвідок. Д та ФС належать до суміжних лінгвістичних дисциплін, які мають спільні ознаки. Специфіка їх співвідношення розглядається спеціалістами в залежності від того, яке з багатьох визначень Д береться за основу. Констатується різнородовість, різнопорядковість, різноприродність Д та ФС. Поряд 3 цим, аргументується думка про певну ієрархічну підпорядкованість методів стилістики та дискурс-аналізу. Як бачимо, питання їх співвідношення не має i не може мати однозначного розв'язання, все ще залишається дискусійним, що дозволяє говорити про необхідність подальших наукових рефлексій.

\section{Література:}

1. Арутюнова, Н. Д. «Дискурс.» Лингвистический энииклопедический словарь, гл. ред. В. Н. Ярцева (Москва, Советская энциклопедия, 1990): 136-137.

2. Дейк, Т. А. ван. «Анализ новостей как дискурса.» Язык. Познание. Коммуникация (Б., БГК им. И. А. Бодуэна де Куртенэ, 2000): 111-160.

3. Виноградов, В. В. «Итоги обсуждения вопросов стилистики.» Вопросыязыкознания 1(1955): 60-87.

4. Гайда, С.«Актуальные задачи стилистики.» Актуальные проблемы стилистики 1 (2015): 11-21.

5. Гоффманнова, Я. «Концепция стилеобразующих факторов и возможности ее модификации в настоящеевремя.» Актуальные проблемы стилистики 1(2015): 51-57.

6. Єрмоленко С., Бибик С., Ганжа А. та ін. «Лінгвостилістика та культура мови на межі століть: полілог поколінь.» Украӥнська мова 4 (2016): 24-40.

7. Єрмоленко, С. Я. Нариси з української словесності. Стилістика та культура мови (Київ, Довіра, 1999), 431.

8. Кожина М. Н., Дускаева Л. Р., Салимовский В. А. Стилистика русского языка 
(Москва,Флинта: Наука, 2008), 464.

9. Крисанова, Т. А. «Функціональний стиль vs дискурс.» Наукові записки Національного університету “Острозька академія”, Серія “Філологічна”62(2016): 188-190.

10. Мацько Л. І., Сидоренко О. М., Мацько О. М. Стилістика украӥнської мови (Київ, Вища школа, 2003), 462.

11. Негрышев, А. А. «Текст в перспективе стилистики и дискурс-анализа: к методологиии сследования на материале новостного медиадискурса.» Stylistyka XXIII (Opole,Wydawnictwo Uniwersytetu Opolskiego, 2014): 149-161.

12. Орлова, О. В.«Проблема соотношения понятий стиля и дискурса в лингвистике начала XXI в. в контексте идей М. Н. Кожиной.» Вестник Томского государственного университета, Серия«Филология» 4 (24)(2013): 19-25.

13. Селиванова, Е. А.Основы лингвистической теории текста и коммуникации (Киев, Брама, изд-во О. Ю. Вовчок, 2004), 336.

14. Серио, П.«Как читают тексты во Франции.» Квадратура смысла: Франиузская школа анализа дискурса (Москва, ОАО ИГ “Прогресс”, 1999): 12-53.

15. Степанов, Ю. С.Франиузская стилістика (Москва,Высшая школа, 1965), 355.

16. Фуко, М. Археология знания (СПб, ИЦ “ГуманитарнаяАкадемия”; Университетская книга, 2004), 416.

17. Хованская, З. И.Стилистика франиузького язика (Москва,Высшая школа, 1984), 344.

18. Шевченко, И. С. «Дискурс и стиль: проблемы эвристики.» Функцииональная лингвистика 4(2012): 313-315.

19. Чернявская, В. Е. Дискурс власти и власть дискурса: проблемы речового воздействия (Москва,Флинта: Наука, 2006), 136.

20. Чернявская, В. Е.«Дискурс как фантомный объект: от текста к дискурсу и обратно?» Когниция, коммуникация, дискурс 3(2011): 86-95.

21. Чернявская, В. Е.Лингвистика текста: поликодовость, интертекстуальность, интердискурсивность (Москва, Книжныйдом “ЛИБРОКОМ”, 2009), 248.

\section{References:}

1. Arutyunova, N. D. «Diskurs [Discourse].» Lingvisticheskiy entsiklopedicheskiy slovar', gl. red. V. N. Yartseva (1990): 136-137 (In Russ).

2. Deyk T. A. van. «Analiz novostey kak diskursa [Analysis of news as a discourse].» Yazyk. Poznaniye. Kommunikatsiya (2000): 111-160 (In Russ).

3. Vinogradov, V. V. «Itogi obsuzhdeniya voprosov stilistiki [Results of discussion of questions of stylistics].» Voprosy yazykoznaniya 1 (1955): 60-87 (In Russ).

4. Gayda, S. «Aktual'nyye zadachi stilistiki [Actual problems of stylistics].» Aktual'nyye problemy stilistiki 1 (2015): 11-21 (In Russ).

5. Goffmannova, Ya. «Kontseptsiya stileobrazuyushchikh faktorov i vozmozhnosti yeye modifikatsii v nastoyashcheye vremya [The concept of style-forming factors and the possibility of its modification at the present time].» Aktual'nyye problemy stilistiki 1 (2015): 51-57 (In Russ).

6. Yermolenko S., Bybyk S., Hanzha A. ta in. «Linhvostylistyka ta kul'tura movy na mezhi 
stolit': poliloh pokolin' [Linguistic and language culture at the turn of the century: the polylog of generations].» Ukrayins'ka mova 4 (2016): 24-40 (In Ukr).

7. Yermolenko S. Ya. Narysy z ukrayins'koyi slovesnosti. Stylistyka ta kul'tura movy [Essays on Ukrainian Literature. Stylistics and language culture] (Kyi'v, Dovira, 1999), 431 (In Ukr).

8. Kozhina M. N., Duskayeva L. R., Salimovskiy V. A. Stilistika russkogo yazyka [Stylistics of the Russian language] (Moskva, Flinta: Nauka, 2008), 464 (In Russ).

9. Krysanova, T. A. «Funktsional'nyy styl' vs dyskurs [Functional style vs. discourse].» Naukovi zapysky Natsional'noho universytetu "Ostroz'ka akademiya”, Seriya "Filolohichna" 62 (2016): 188-190 (In Ukr).

10. Mats'ko L. I., Sydorenko O. M., Mats'ko O. M. Stylistyka ukrayins'koyi movy [Stylistics of the Ukrainian language] (Kyi'v, Vyshha shkola, 2003), 462 (In Ukr).

11. Negryshev, A. A. «Tekst v perspektive stilistiki i diskurs-analiza: k metodologii issledovaniya na materiale novostnogo mediadiskursa [Text in the perspective of stylistics and discourse analysis: to the methodology of research on the material of a news media discourse].» Stylistyka XXII (2014): 149-161 (In Russ).

12. Orlova, O. V. «Problema sootnosheniya ponyatiy stilya i diskursa v lingvistike nachala XXI v. v kontekste idey M. N. Kozhinoy [The problem of the correlation of the concepts of style and discourse in the linguistics of the beginning of the XXI century in the context of M. N. Kozhina's ideas].» Vestnik Tomskogo gosudarstvennogo universiteta. Filologiya 4 (24) (2013): 19-25 (In Russ).

13. Selivanova, Ye. A. Osnovy lingvisticheskoy teorii teksta i kommunikatsii [Basics of the linguistic theory of text and communication] (Kiev, Brama, izd-vo O. Ju. Vovchok, 2004), 336 (In Russ).

14. Serio, P. «Kak chitayut teksty vo Frantsii [How the texts are read in France].» Kvadratura smysla: Frantsuzskaya shkola analiza diskursa (Moskva, OAO IG “Progress”, 1999): 12-53 (In Russ).

15. Stepanov, Yu. S. Frantsuzskaya stilistika [French stylistics] (Moskva, Vysshaja shkola, 1965), 355 (In Russ).

16. Fuko, M. Arkheologiya znaniya [Archeology of knowledge] (SPb, IC “Gumanitarnaja Akademija"; Universitetskaja kniga, 2004), 416 (In Russ).

17. Khovanskaya Z. I. Stilistika frantsuzskogo yazyka [Stylistics of the French language] (Moskva, Vysshaja shkola, 1984), 344 (In Russ).

18. Shevchenko, I. S. «Diskurs i stil': problemy evristiki [Discourse and Style: Problems of Heuristics].» Funktsional'naya lingvistika 4 (2012): 313-315 (In Russ).

19. Chernyavskaya, V. Ye. Diskurs vlasti $i$ vlast' diskursa: problemy rechevogo vozdeystviya [Discourse of Power and Discourse Power: Problems of Speech Impact] (Moskva, Flinta: Nauka, 2006), 136 (In Russ).

20. Chernyavskaya, V. Ye. «Diskurs kak fantomnyy ob"yekt: ot teksta k diskursu i obratno? [Discourse as a phantom object: from text to discourse and back?].» Kognitsiya, kommunikatsiya, diskurs 3 (2011): 86-95 (In Russ).

21. Chernyavskaya, V. Ye. Lingvistika teksta: polikodovost', intertekstual'nost', interdiskursivnost' [Linguistics of the text: polycode, intertextuality, interdiscursivity] (Moskva, Knizhnyj dom “LIBROKOM”, 2009), 248 (In Russ).

Actual Problems of Linguistics [Aktual'ni problemy movoznavstva]

(C) Kovalova O. [Koval'ova O.], chelena2076@gmail.com

Discourse and Functional Style: the Problem of the Correlation [Dyskurs ta funkcional'nyj styl': problema spivvidnoshennja] (in Ukrainian) 


\title{
ЛЕКСИКО-СЕМАНТИЧНА КЛАСИФІКАЦІЯ ДІЕСЛІВ ГНОСТИЧНОГО ПСИХІЧНОГО СТАНУ В УКРАЇНСЬКІЙ, НІМЕЦЬКІЙ ТА АНГЛІЙСЬКІЙ МОВАХ
}

\author{
Коренькова Олександра Андріївна, alexandrakorenkova23@gmail.com \\ аспірантка кафедри германських та східних мов \\ Міжнародний гуманітарний університет
}

У статті розглянуто поняття та лексико-семантичну класифікаиію дієслів гностичного психічного стану на матеріалі сучасної української, німецької та англійської мов. Особлива увага приділяється виявленню наявності спільних та відмінних рис у семантиці дієслів гностичного психічного стану в украӥнській, німецькій та англійській мовах. Теоретична значущість дослідження полягає у встановленні поняття та лексико-семантичних особливостей дієслів гностичного психічного стану як окремого лексико-семантичного класу в кожній із вище зазначених мов, що може привести до подальшого розвитку досліджень лексики на позначення психічного стану. Для встановлення лексико-семантичної класифікаиії дієслів гностичного психічного стану в українській, німещькій та англійській мовах, а також виявлення спільних та відмінних рис у мовах дослідження, у повному обсязі використано корпус словникової вибірки дісслів гностичного психічного стану на матеріалі репрезентативних тлумачних словників сучасної української, німецької та англійської мов. Отримані результати статичної обробки словникової вибірки використовувалися для встановлення ступеня продуктивності лексико-семантичних груп у кожній із мов дослідження. Проведений аналіз існуючих у літературі спроб створення класифікаиій гностичних психічних станів у психології та дієслівної лексики на позначення гностичних психічних станів у лінгвістииі виявив відсутність конкретного впорядкування та опису усього обсягу понять "гностичний психічний стан" та “дієслово гностичного психічного стану”. Системний аналіз масиву наукових даних дав змогу надати власне тлумачення дієсловам гностичного психічного стану у роботі та описати особливості зазначеного класу дієслів на лексико-семантичному рівні в межах зіставного дослідження на матеріалі украӥнської, німецької та англійської мов.

Ключові слова: лексико-семантична класифікачія, дісслова гностичного психічного стану, семантичний аналіз.

Актуальні проблеми мовознавства [Актуальные проблемы языкознания] СКоренькова О. А. [Коренькова А. A.], alexandrakorenkova23@gmail.com Лексико-семантична класифікація дісслів гностичного психічного стану в українській, німецькій та англійській мовах [Лексико-семантическая классификация глаголов гностического психического состояния в украинском, немецком и английском языках] (Українською / На укр. яз) 


\title{
ЛЕКСИКО-СЕМАНТИЧЕСКАЯ КЛАССИФИКАЦИЯ ГЛАГОЛОВ ГНОСТИЧЕСКОГО ПСИХИЧЕСКОГО СОСТОЯНИЯ В УКРАИНСКОМ, НЕМЕЦКОМ И АНГЛИЙСКОМ ЯЗЫКАХ
}

\author{
Коренькова Александра Андреевна, alexandrakorenkova23@gmail.com \\ аспирантка кафедры германских и восточных языков \\ Международный гуманитарный университет
}

\begin{abstract}
B статье рассматривается понятие $u$ лексико-семантическая классификация глаголов гностического психического состояния на материале современного украинского, немецкого и английского языков. Особое внимание посвящено определению наличия общих и отличительных черт в семантике глаголов гностического психического состояния в украинском, немецком и английском языках. Теоретическая значимость исследования заключается в определении понятия $и$ лексико-семантических особенностей глаголов гностического психического состояния в качестве отдельного лексико-семантического класса в каждом из языков исследования, что может создать основу для дальнейтего изучения лексики, обозначающей психические состояния. Для установления лексикосемантической классификаџии глаголов гностического психического состояния в украинском, немецком и английском языках, а также выявления общих и отличительных черт в языках исследования, в полной мере использован корпус словарной выборки глаголов гностического психического состояния на материале репрезентативных толковых словарей современного украинского, немецкого и английского языков. Полученные результаты статистической обработки словарной выборки использовались для установления степени продуктивности лексико-семантических групп в каждом из языков исследования. Проведенный анализ представленных в литературе классификаций гностических психических состояний в психологии и глагольной лексики, обозначающей гностические психические состояния в лингвистике, выявил отсутствие адекватной классификации и описания глаголов гностического психического состояния. Системный анализ массива имеющихся научных данных создал предпосылки для разработки авторского определения глаголов гностического психического состояния и описания лексико-семантических особенностей указанного класса глаголов в рамках сопоставительного исследования на материале украинского, немецкого и английского языков.
\end{abstract}

Ключевые слова: лексико-семантическая классификация, глаголь гностического психического состояния, семантический анализ.

Actual Problems of Linguistics [Aktual'ni problem movoznavstva] (C) Korenkova O. [Koren'kova O.], alexandrakorenkova23@gmail.com

Lexical-Semantic Classification of Gnostic Mental Verbs in Ukrainian, German and English [Leksyko-semantychna klasyfikacija dijesliv gnostychnogo psyhichnogo stanu v ukrai'ns'kij, nimec' kij ta anglijs'kij movah] (in Ukrainian) 


\title{
LEXICAL-SEMANTIC CLASSIFICATION OF GNOSTIC MENTAL VERBS IN UKRAINIAN, GERMAN AND ENGLISH
}

\author{
Oleksandra Korenkova, alexandrakorenkova23@gmail.com \\ Postgraduate student of German and Oriental Languages Department \\ International Humanitarian University
}

The article deals with the concept and lexical-semantic classification of the gnostic mental state verbs on the material of modern Ukrainian, German and English languages. Particular attention is given to determination of common and distinctive features in the semantics of the gnostic mental state verbs in Ukrainian, German and English. The theoretical significance of the research lies in the definition of the concept and lexicalsemantic features of the gnostic mental state verbs as a separate lexical-semantic class in each of the researched languages, which might lead to the further development of the study of lexics denoting mental states. The lexical-semantic classification of the gnostic mental verbs in Ukrainian, German and English, identification of common and distinctive features in the researched languages was made basing on the body of the authoritative dictionaries of modern Ukrainian, German and English languages. The results of the statistical processing of the dictionary samples helped to establish the degree of productivity of lexicalsemantic groups in each of the above mentioned languages. The analysis of already made attempts to create some classifications of gnostic mental states in psychology and verbal lexicon, which denotes gnostic mental states in linguistics, revealed the absence of an adequate classification and description of these notions - "gnostic mental state" and" gnostic mental verbs". Systematic analysis of the scientific data provided an opportunity to define the gnostic mental verbs in the research and describe the features of this verbal class on the lexical-semantic level within the framework of comparative research on the material of Ukrainian, German and English.

Key words: lexical-semantic classification, gnostic mental verbs, semantic analysis.

Вступ. Важливість дослідження проблеми вербального прояву психічних станів людини зумовлює актуальність дослідження дієслів психічного стану (далі ДПС) у лінгвістиці. В той же час, проблематика їх дослідження полягає у тому, що вони характеризуються рухливістю, взаємозв'язком з психічними процесами і властивостями особистості, індивідуальною своєрідністю та великим різноманіттям. Психічні стани, як й інші психічні явища, існують у вигляді переживань, ідей у свідомості людини 
та в тій частині психіки, яку називають несвідоме. Це означає, що їх неможливо сприйняти за допомогою органів чуття та дослідити методами природничих наук. При цьому проблема психічних станів людини, яка понад чотири десятиліття тому увійшла у вітчизняну психологію як теоретично i практично недостатньо вивчена, залишається такою і в наш час. Про це свідчить той факт, що жодний підручник із загальної психології серед глибоко проаналізованих явищ психіки не мав і не має такого, як психічний стан. Таким чином, і дослідження лексики на позначення психічного стану у лінгвістиці не має достатньої теоретичної та практичної бази.

Вивчення дієслів на позначення психічних станів людини в сучасній лінгвістиці зумовило накопичення значного теоретичного потенціалу, але необхідно зазначити, що для більшості вищезазначених робіт предметом дослідження $є$ не дієслова психічного стану, а їх окремі класи або групи. Так, предметом дослідження лінгвістів виступали: особливості функціонування ДПС в англійській та китайській мовах [Cheung 2014]; структура аргументу у ДПС [Engelberg 2013]; когнітивні дієслова в лексико-семантичній системі англійської мови [Ділай 2014]; субстанціальні характеристики дієслів інформаційної діяльності [Кумейко 2013]; параметри словотвірної парадигми відприкметникових інхоативних дієслів на позначення внутрішнього стану суб'єкта в українській мові [Кушлик 2013]; дослідження семантики дієслів, які виражають психоемоційний стан особи в англійській, німецькій, іспанській та українській мовах [Навроцька 2013]; семантика дієслів знання [Падучева 2004]; мотиваційна основа дієслів на позначення психічного стану в українській та угорській мовах [Ханикіна 2017]; конструктивна варіативність дієслів психічного стану на матеріалі європейських мов [Kutscher 2009]. Відсутність порівняльного дослідження на матеріалі української, німецької та англійської мов визначає актуальність вивчення дієслів психічного стану.

\section{Об'єкт і предмет, мета і завдання дослідження.}

Об'єктом дослідження виступають дієслова гностичного психічного стану (далі ДГПС) в сучасній українській, німецькій та англійській мовах. У свою чергу, предметом дослідження є лексико-семантичні особливості ДГПС у мовах дослідження. Мета статті полягає у встановленні лексикосемантичної класифікації ДГПС, а також виявленні спільних та відмінних рис

Actual Problems of Linguistics [Aktual'ni problem movoznavstva] (C) Korenkova O. [Koren'kova O.], alexandrakorenkova23@gmail.com Lexical-Semantic Classification of Gnostic Mental Verbs in Ukrainian, German and English [Leksyko-semantychna klasyfikacija dijesliv gnostychnogo psyhichnogo stanu v ukrai'ns'kij, nimec'kij ta anglijs'kij movah] (in Ukrainian) 
у семантиці ДГПС в українській, німецькій та англійській мовах. Мета дослідження визначає необхідність вирішення наступних завдань: розглянути поняття ДГПС та його складові групи у лексико-семантичному аспекті в українській, німецькій та англійській мовах; дослідити лексико-семантичні особливості ДГПС в кожній з мов дослідження; зіставити та проаналізувати лексико-семантичні особливості ДГПС в українській, німецькій та англійській мовах.

\section{Виклад основного матеріалу дослідження.}

Під дієсловами психічного стану у роботі розуміємо дієслова, що позначають внутрішній прояв стану суб'єкта та мотивовані такими ознаками: переживати стан - набувати і виражати внутрішні якості. До класифікації дієслів психічного стану у роботі ми включаємо семантичний, видовий, фазовий та оцінний складники дієслів. Окрім того, для визначення лексикосемантичної класифікації ДПС застосовано ономасіологічний принцип, при якому дієслова 3 різними афіксами об'єднуються на основі тотожності денотативних сем на позначення психічного стану. Доцільність застосування ономасіологічного принципу при здійсненні зіставних досліджень підтверджено багатьма лінгвістами [Арутюнова 1988; Кубрякова 2008; Селиванова 2005; Ступак 2011; Ханикіна 2017]. Ономасіологічний підхід до вивчення мовних одиниць, а також існуюча у психологічній науці класифікація психічних станів [Ильин 2005; Левитов 1964; Леонова 1984; Мясищев 1966; Сосновикова 1975], дозволяють виявити у словниковому складі української, німецької та англійської мов такі лексико-семантичні класи ДПС, як: 1) дієслова гностичного психічного стану; 2) дієслова емоційного психічного стану; 3) дієслова вольового психічного стану та, відповідно, здійснити семантичну класифікацію ДПС.

В залежності від семантики психічного стану, кожен лексикосемантичний клас розподіляється на лексико-семантичні групи (далі ЛСГ). До ЛСГ ДГПС відносимо дієслова на позначення: розуміння, мрійливості, вагання, зосередженості.

Семантика ДГПС позначає ситуацію набуття суб'єктом гностичного психічного стану. Вони описуються загальною ФТ "S перебуває Vcond у стані Gnost”, де S - суб'єкт, що перебуває у психічному стані, Vcond представлено ДПС, семантика гностичного психічного стану виражена учасником Gnost, 
наприклад ДГПС (1) відати “знати, мати про що-небудь уявлення, усвідомлювати” [СУМ, с. 284], що має ФТ “S перебуває Vcond у стані усвідомлення Gnost”.

Для опису семантики ДПС у роботі використовуються традиційні семантичні ролі, виокремлені сучасними лінгвістами [Арутюнова 1988; Гордон 1980; Селіванова 2005; Ступак 2011; Kutscher 2009]. До семантичних ролей учасників ДГПС відносимо: 1) Cause - причина, за якої суб'єкт перебуває у стані; 2) фазовість (Phase) - фаза перебування суб'єкта у психічному стані; 3) експресивність (Expres) - зовнішній прояв психічного стану; 4) Intens - інтенсивність вияву психічного стану; 5) негативність (Neg) - відсутність психічного стану; 6) множинність (Plur).

На основі таких додаткових семантичних ознак, як “фазовість”, “інтенсивність", “причина", “множинність”, “експресивність”, “множинність” та їх комбінацій у роботі в межах кожної ЛСГ виділяємо лексико-семантичні підгрупи.

Лексико-семантичний клас ДГПС виступає другим за продуктивністю 3-поміж виділених класів ДПС в українській (19,0 \%) та англійській $(30,6$ \%) мовах, а також є найчисленнішим на матеріалі німецької мови (34,7 \%) (див. табл. 1).

\section{Таблиия 1.Продуктивність ДПС в українській, німецькій та англійській}

\section{мовах}

\begin{tabular}{|c|c|c|c|c|}
\hline \multirow[t]{2}{*}{ № } & \multirow{2}{*}{$\begin{array}{c}\text { Семантичні класи } \\
\text { ДПС }\end{array}$} & \multicolumn{3}{|c|}{ Продуктивність в мовах дослідження } \\
\hline & & укр. & нім. & англ. \\
\hline 1 & ДЕПС & $406(58,0 \%)$ & $130(30,7 \%)$ & $130(39,0 \%)$ \\
\hline 2 & ДГПС & $133(19,0 \%)$ & $147(34,7 \%)$ & $102(30,6 \%)$ \\
\hline 3 & ДВПС & $107(15,3 \%)$ & $126(29,7 \%)$ & $77(23,2 \%)$ \\
\hline 4 & Полісемантичні ДПС & $54(7,7 \%)$ & $21(4,9 \%)$ & $24(7,2 \%)$ \\
\hline & PA30M & $700(100 \%)$ & $424(100 \%)$ & $333(100 \%)$ \\
\hline
\end{tabular}

Під дієсловами гностичного психічного стану у роботі розуміються дієслова, які позначають розумове сприйняття, створення в уяві образів, вагання, зосередженість суб'єкта. За результатами дослідження, в межах ДГПС виокремлено 4 семантичні групи (див. табл. 2):

Actual Problems of Linguistics $\overline{\text { [Aktual'ni problem movoznavstva] }}$ (C) Korenkova O. [Koren'kova O.], alexandrakorenkova23@gmail.com Lexical-Semantic Classification of Gnostic Mental Verbs in Ukrainian, German and English [Leksyko-semantychna klasyfikacija dijesliv gnostychnogo psyhichnogo stanu v ukrai'ns'kij, nimec'kij ta anglijs'kij movah] (in Ukrainian) 
STUDIA LINGUISTICA, 2018. - Вип. 13 : 123-133

\section{Таблиия 2.Продуктивність ДГПС в мовах дослідження}

\begin{tabular}{|c|c|c|c|c|c|c|c|}
\hline \multicolumn{2}{|c|}{$\begin{array}{l}\text { Семантичні } \\
\text { групи ДГПС }\end{array}$} & Розуміння & Мрійливості & \multicolumn{2}{|c|}{ Вагання } & $\begin{array}{l}\text { Зосередже- } \\
\text { ності }\end{array}$ & PA30M \\
\hline \multirow{3}{*}{ 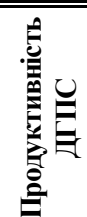 } & англ. & $64(62,7 \%)$ & $18(17,7 \%)$ & $13(12,7 \%)$ & $7(6,9 \%)$ & \multicolumn{2}{|c|}{$102(100 \%)$} \\
\hline & нім. & $94(63,9 \%)$ & $29(19,7 \%)$ & \multicolumn{2}{|c|}{$13(8,8 \%)$} & $11(7,6 \%)$ & $147(100 \%)$ \\
\hline & укр. & $84(63,1 \%)$ & $27(20,3 \%)$ & \multicolumn{2}{|c|}{$14(10,5 \%)$} & $8(6,1 \%)$ & $133(100 \%)$ \\
\hline
\end{tabular}

1) ДГПС зі значенням "розуміння" позначають розумове сприйняття суб'єктом явищ дійсності, а саме знання, міркування, мислення, роздуму, аналізу, усвідомлення, наприклад ДГПС (2) думати “розмірковувати над чимнебудь, мислити” [СУМ: 622] має ФТ "S перебуває Vcond у стані міркування Gnost". У межах ДГПС зі значенням "розуміння" превалюють ДГПС без додаткових ознак, однак наявні і такі лексико-семантичні підгрупи, як “фазовість”, “інтенсивність”, “множинність”, “причина”, “фазовість + причина”, “фазовість + інтенсивність” (див. табл. 3).

Таблиия 3. Наявність / відсутність додаткових семантичних ознак ДГПС в мовах дослідження

\begin{tabular}{|c|c|c|c|c|c|c|c|c|c|}
\hline \multicolumn{2}{|c|}{$\begin{array}{c}\text { Додаткові } \\
\text { семантичні } \\
\text { ознаки }\end{array}$} & \multirow{2}{*}{ 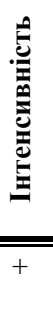 } & \multirow{2}{*}{ 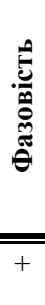 } & \multirow{2}{*}{ } & \multirow{2}{*}{ 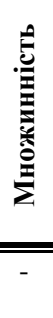 } & \multirow{2}{*}{ 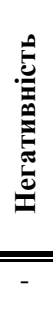 } & \multirow{2}{*}{ 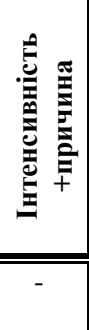 } & \multirow{2}{*}{ 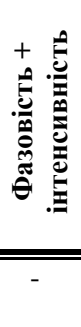 } & \multirow{2}{*}{ 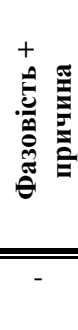 } \\
\hline \multirow{3}{*}{ 氞 } & англ. & & & & & & & & \\
\hline & нім. & + & + & + & - & - & + & + & + \\
\hline & укр. & + & + & - & + & + & + & - & - \\
\hline
\end{tabular}

2) ДГПС зі значенням “мрійливості” позначають створення суб’єктом в уявленні образів, стану замріяності тощо, наприклад ДГПС (3) мріяти “думати про здійснення чогось бажаного, прагнути в думках до чогось” [СУМ2, 233], що має ФТ “S перебуває Vcond у стані мрійливості Gnost”. 3-поміж 
ДГПС зі значенням “мрійливості” виділяємо такі додаткові семантичні ознаки, як “фазовість”, “інтенсивність”, “множинність”, “негативність” (див. табл.3).

3) ДГПС зі значенням “вагання” позначають переживання суб'єктом неспроможності відразу вирішити що-небудь; роздумуючи, схилятися то до одного, то до іншого рішення, наприклад ДГПС (4) вагатися "відчувати неспроможність відразу вирішити що-небудь” [CУМ, 154], що має ФТ “S перебуває Vcond у стані вагання Gnost". Серед ДГПС зі значенням "вагання" окрім дієслів без додаткових семантичних ознак виявлено лексико-семантичну підгрупу із додатковою ознакою “фазовість“ (див. табл. 3).

4) до ДГПС зі значенням “зосередженості” у роботі відносимо дієслова, які позначають напруженість та зібраність думок або почуттів суб’єкта, наприклад ДГПС (5) зосереджуватися “ставати зібраним, готовим до чогонебудь, напружуючи свою увагу, свої думки, зусилля і т. ін.”, що має ФТ “S перебуває Vcond у стані зосередженості Gnost". 3-поміж ДГПС зі значенням “зосередженості“" не виявлено лексико-семантичних підгруп.

\section{Висновки та перспективи подальших розвідок.}

Підсумовуючи, зазначимо, що на відміну від німецької мови, в якій ДГПС займають перше місце за продуктивністю, спільною рисою для ДГПС в українській та англійській мовах $є$ ступінь їхньої продуктивності - вони посідають друге місце 3-поміж інших семантичних класів ДПС (див. табл. 1).

Лексико-семантичний аналіз ДГПС в українській, німецькій та англійській мовах свідчить, що для них характерна однакова система загальної семантичної інформації, уміщеної в дієслівних значеннях, за допомогою яких виражені основні види гностичних психічних станів - у мовах дослідження в рамках класу ДГПС виділено 4 лексико-семантичні групи. Таким чином, ДГПС у мовах дослідження співпадають за якісним, але різняться за кількісним складом дієслів.

Таким чином, порівнюючи кількісні показники ДГПС згідно зі словниковою вибіркою, можна відмітити їхню більшу продуктивність у німецькій мові (див. табл.1.).

Спільною рисою функціонування ДГПС у всіх мовах дослідження $\epsilon$ найбільша продуктивність таких лексико-семантичних груп, як ДГПС зі значенням “розуміння” та “мрійливості”. На матеріалі словникової вибірки в українській та англійській мовах третє місце займають ДГПС зі значенням

Actual Problems of Linguistics $\overline{\text { [Aktual'ni problem movoznavstva] }}$ (C) Korenkova O. [Koren'kova O.], alexandrakorenkova23@gmail.com Lexical-Semantic Classification of Gnostic Mental Verbs in Ukrainian, German and English [Leksyko-semantychna klasyfikacija dijesliv gnostychnogo psyhichnogo stanu v ukrai'ns'kij, nimec'kij ta anglijs'kij movah] (in Ukrainian) 
“вагання”, останнє - ДГПС зі значенням “зосередженості”. На матеріалі німецької мови, навпаки, третє місце посідають ДГПС зі значенням “зосередженості”, непродуктивними виявилися ДГПС зі значенням “вагання” (див. табл. 2).

У структурі додаткової семантичної інформації в українській, німецькій та англійській мовах спостерігається ряд відмінностей. Серед ДГПС для німецької мови характерна більш розгалужена, ніж в українській та англійській мовах, система додаткових ознак, що виявляється в їх кількості (нім. мова - 6, укр. мова - 4, англ. мова - 2), а також у різновидах самих ознак (див. табл.3.).

Незважаючи на те, що у мовах дослідження превалюють ДГПС без додаткових ознак, спільною рисою в українській, німецькій та англійській мовах є найбільша продуктивність таких додаткових ознак, як “фазовість” та “інтенсивність”. Виняток складають поодинокі випадки реалізації семантичних ознак "множинність" та "негативність", які відмічені тільки в українській мові у зв'язку 3 тим, що їх значення передається за допомогою засобів префіксального словотвору. Окрім того, відмінною рисою в німецькій мові у порівнянні із українською та англійською, є наявність додаткових ознак “фаза + інтенсивність”, “причина”, “фазовість + причина”, “інтенсивність + причина”.

Здебільшого наявність додаткових семантичних ознак у мовах дослідження зумовлена семантикою ДГПС, у поодиноких випадках в українській та німецькій мовах - деривацією.

У подальших розвідках на матеріалі розглянутої у роботі лексикосемантичної класифікації ДГПС буде проведено їх семантико-синтаксичний аналіз на матеріалі текстів української, німецької та англійської мов.

\section{Література:}

1. Арутюнова, А. Р. «Лексические и семантические классы глаголов в немецком языке.» Автореф. дис. канд. филол. наук, Москва, 1988.

2. Гордон, Е. Я. «Семантические особенности каузативных глаголов чувств в русском языке.» Русский язык. Теория и методика преподавания (Душанбе, Таджикский ГУ, 1980): 77-82.

3. Ділай, І. «Когнітивні дієслова в лексико-семантичній системі англійської мови: історія та перспетиви дослідження.» Вісник Львівського університету. Серія «Іноземні мови» 22 (2014): 28-37

4. Ильин, Е. П. Психофизиология состояний человека (СПб., Питер, 2005), 412.

5. Кубрякова, Е. А. Части речи в ономасиологическом освещении (Москва, Изд-во ЛКИ, 2008б), 120.

6. Кумейко, Т. А. «Субстанціальні характеристики дієслів інформаційної діяльності.»

Актуальні проблеми мовознавства [Актуальные проблемы языкознания] СКоренькова О. А. [Коренькова A. A.], alexandrakorenkova23@gmail.com Лексико-семантична класифікація дісслів гностичного психічного стану в українській, німецькій та англійській мовах [Лексико-семантическая классификация глаголов гностического психического состояния в украинском, немецком и английском языках] (Українською / На укр. яз) 
Філологічні науки, кн. 2(2013): 221-224.

7. Кушлик, О. П. Параметри словотвірної парадигми відприкметникових інхоативних дієслів на позначення внутрішнього стану суб'єкта в українській мові.» Лінгвістичні дослідження 36(2013): 93-102.

8. Левитов, Н. Д. О психических состояниях человека (Москва, 1964).

9. Леонова, А. Б. Психодиагностика функииональных состояний человека (Москва, 1984).

10. Мясищев, В.Н. «Психические состояния и отношения человека.» Обозрение психиатрии и медицинской психологии им. В. М. Бехтерева 1-2 (1966).

11. Навроцька, Н. А. «Дієслова, які виражають психоемоційний стан особи в англійській, німецькій, іспанській та українській мовах.» Science and Education a New Dimension, Philology I (3), Issue13 (2013): 84-86.

12. Падучева, Е. В. Динамические модели в семантике лексики (Москва, Языки славянской культуры, 2004), 608.

13. Селиванова, М. Ю. «Синтаксические конструкции с каузативными глаголами и их смысловое предназначение.» Автореф. дис. канд. филол. наук, Нижний Новгород, 2005.

14. Сосновикова, Ю. Е. Психические состояния человека, их классификаиия и диагностика (Горький, 1975).

15. Ступак, І. В. «Структурно-семантичні та функціональні характеристики похідних каузативних дієслів у німецькій та українській мовах.» Типологічні, зіставні, діахронічні дослідження, т. 6 (Донецьк, ДонНУ, 2011), 470.

16. Ханикіна, Н. В. «Мотиваційна основа дієслів на позначення фізичного і психічного станів суб'єкта в українській та угорській мовах.» (Дис. канд. філол. наук,Київ, 2017), 218.

17. Chi-Hang, Cheung Candice, Larson Richard K. «Psych verbs in English and Mandarin.» Nat Lang Linguist Theory. Springer Science+Business Media (Dordrecht, 2014), 63.

18. Engelberg Stefan. «The argument structure of psych-verbs: A quantitative corpus study on cognitive entrenchment.» Constructional Approaches to Argument Structure in German, eds. Hans Boas \& Alexander Ziem (Boston, Berlin, De Gruyter Mouton, 2014).

19. Kutscher Silvia. Kausalität und Argumentrealisierung. Zur Konstruktionsvarianz bei Psychverben am Beispiel europäischer Sprachen (Tübingen, Max Niemeyer Verlag. 2009), 178.

\section{References:}

1. Arutjunova, A. R. «Leksicheskie i semanticheskie klassy glagolov v nemeckom jazyke [Lexical and semantic classes of verbs in German].» Avtoref. dis. kand. filol. nauk, Moskva, 1988.

2. Gordon, E. Ja. «Semanticheskie osobennosti kauzativnyh glagolov chuvstv v russkom jazyke [Semantic features of causative verbs of feelings in Russian].» Russkij jazyk. Teorija i metodika prepodavanija (Dushanbe, Tadzhikskij GU, 1980): 77-82.

3. Dilaj, I. «Kognitivni dieslova v leksiko-semantichnij sistemi anglijs'koï movi: istorija ta perspetivi doslidzhennja [Cognitive verbs in lexical-semantic system of English: history and perspectives of the research].»Visnik L'vivs'kogo universitetu, Serija «Inozemni movi» 22 (2014): 28-37. (In Ukr.).

4. Il'in, E. P. Psihofiziologija sostojanij cheloveka [Psychophysiology of human states] (SPb., Piter, 2005), 412.

Actual Problems of Linguistics $\overline{\text { [Aktual'ni problem movoznavstva] }}$ (C) Korenkova O. [Koren'kova O.], alexandrakorenkova23@gmail.com

Lexical-Semantic Classification of Gnostic Mental Verbs in Ukrainian, German and English [Leksyko-semantychna klasyfikacija dijesliv gnostychnogo psyhichnogo stanu v ukrai'ns'kij, nimec'kij ta anglijs'kij movah] (in Ukrainian) 
5. Kubrjakova, E. A. Chasti rechi v onomasiologicheskom osveshhenii [Parts of speech in onomasiological discourse] (Moskva, Izd-vo LKI, 2008b), 120.

6. Kumejko, T. A. «Substancial'ni harakteristiki diesliv informacijnoï dijal'nosti [Substantial characteristics of the verbs of information activity].» Filologichni nauki, kniga 2 (2013): 221-224. (In Ukr.).

7. Kushlik, O.P. «Parametri slovotvirnoï paradigmi vidprikmetnikovih inhoativnih diesliv na poznachennja vnutrishn'ogo stanu sub'ekta $\mathrm{v}$ ukraïns'kij movi [Parameters of the word-formation paradigm of adjectival inhova verbs of the internal state of the subject in Ukrainian].» Lingvistichni doslidzhennja 36 (2013): 93-102. (In Ukr.).

8. Levitov, N. D. O psihicheskih sostojanijah cheloveka [About mental states of a person] (Moskva, 1964).

9. Leonova, A. B. Psihodiagnostika funkcional'nyh sostojanij cheloveka [Psychodiagnosis of human functional states] (Moskva, 1984).

10. Mjasishhev, V. N. «Psihicheskie sostojanija i otnoshenija cheloveka [Mental conditions and human relationships].» Obozrenie psihiatrii i medicinskoj psihologii im. V. M. Behtereva 1-2 (1966).

11. Navroc'ka, N. A. «Dieslova, jaki virazhajut' psihoemocijnij stan osobi v anglijs'kij, nimec'kij, ispans'kij ta ukraïns'kij movah [Verbs that express the psycho-emotional state of a person in English, German, Spanish, and Ukrainian].» Science and Education a New Dimension, Serija «Philology» I (3), Issue 13 (2013): 84-86. (In Ukr.).

12. Paducheva, E. V.Dinamicheskie modeli v semantike leksiki [Dynamic models in the semantics] (Moskva, Jazyki slavjanskoj kul'tury, 2004), 608.

13. Selivanova, M. Ju. «Sintaksicheskie konstrukcii s kauzativnymi glagolami i ih smyslovoe prednaznachenie [Syntactic constructions with causative verbs and their semantic purpose].» Avtoref. dis. kand. filol. nauk, Nizhnij Novgorod, 2005.

14. Sosnovikova Ju. E. Psihicheskie sostojanija cheloveka, ih klassifikacija i diagnostika [Psychic states of a person, their classification and diagnosis]. Gor'kij, 1975.

15. Stupak, I. V. «Strukturno-semantichni ta funkcional'ni harakteristiki pohidnih kauzativnih diesliv u nimec'kij ta ukraïns'kij movah [Structural-semantic and functional characteristics of derivative causative verbs in German and Ukrainian].» Tipologichni, zistavni, diahronichni doslidzhennja, t. 6 (Donec'k, DonNU, 2011), 470.

16. Hanikina, N. V. «Motivacijna osnova diesliv na poznachennja fizichnogo i psihichnogo staniv sub' $k$ kta v ukraïns'kij ta ugors'kij movah [Motivational basis of verbs for denoting the physical and mental states of the subject in Ukrainian and Hungarian].» (Dis. kand. filol. nauk Kyi'v, 2017), 218.

17. Chi-Hang Cheung Candice, Larson Richard K. «Psych verbs in English and Mandarin.» Nat Lang Linguist Theory. Springer Science +Business Media (Dordrecht, 2014), 63.

18. Engelberg Stefan. «The argument structure of psych-verbs: A quantitative corpus study on cognitive entrenchment.» Constructional approaches to argument structure in German, eds. Hans Boas \& Alexander Ziem (Boston, Berlin, De Gruyter Mouton, 2014).

19. Kutscher Silvia. Kausalität und Argumentrealisierung. Zur Konstruktionsvarianz bei Psychverben am Beispiel europäischer Sprachen (Tübingen, Max Niemeyer Verlag, 2009), 178.

Актуальні проблеми мовознавства [Актуальные проблемы языкознания]

СКоренькова О. А. [Коренькова A. A.], alexandrakorenkova23@gmail.com

Лексико-семантична класифікація дісслів гностичного психічного стану в українській, німецькій та англійській мовах [Лексико-семантическая классификация глаголов гностического психического состояния в украинском, немецком и английском языках] (Українською / На укр. яз) 


\section{УДК 81'811.111}

\section{ЛІНГВОКУЛЬТУРНИЙ КОНЦЕПТ FАSНION КРІЗЬ ПРИЗМУ РЕЛІГІЙНОЇ КОНЦЕПТОСФЕРИ (НА МАТЕРІАЛІ СУЧАСНИХ АНГЛОМОВНИХ МЕДІАРЕСУРСІВ)}

\section{Крисальна Юліана В'ячеславівна, yuliana.krysalna@gmail.com}

асистент

Київський національний університет імені Тараса Шевченка,

Інститут філології

Мода як знакова система здавна сприймалася як невід'ємна частина комунікації, тож із розвитком суспільства ії вплив на світоглядні засади стає дедалі потужснішим. У статті представлена генеза взаємовпливу концептів FASHION ma RELIGION, зроблено спробу їх співставлення як двох світоглядних систем. Означено вербальні та невербальні апеляції до релігійних концептів у репрезентаціях лінгвокультурного концепту FASHION на сучасних англомовних медіаресурсах. Особлива увага приділена християнській традииї як питомій для англійської мови та культури. Побіжно окреслені репрезентації мусульманських релігійних концептів в дискурсі моди, як нові елементи масової культури сучасного англомовного суспільства. У статті проаналізований розвиток ставлення до моди від біблійних текстів до сучасних фешн-видань. У якості матеріалів дослідження, крім Біблійних текстів (у редакиії King James Bible), було використано статті, опубліковані в сучасних модних журналів, сайти відомих будинків моди, тексти релізів та описів модних колекцій, тексти популярних новинних порталів у розділах Blogs, Society, Culture тощо, а також для діахронічної перспективи було залучено тексти англомовних авторів періоду Середньовічча та епохи Відродження. У дослідженні розглядаються сучасні аксіологічні зсуви у культурі та модному дискурсі із широкою палітрою ілюстративного матеріалу. $У$ статті було визначено такі основні стадї актуалізації репрезентацій концепту FASHION, як SHAME - FAST, GRIEF AND SORROW - POWER - VICE - FREEDOM - IDENTITY RELIGION. Результати дослідження показали значний рівень когнітивної модифікації концепту FASHIO та довели антонімічну протилежність початкового та актуального складу ядра концепту FASHION у релігійній площчині.

Ключові слова: кониелт FASHION, кониелт RELIGION, релігійний концелт, когнітивна модифікація.

Actual Problems of Linguistics [Aktual'ni problemy movoznavstva]

(C) Krysalna Y. [Krysal'na Ju.], yuliana.krysalna@gmail.com

The Concept FASHION within the Cognitive Framework of Religion (Based on Contemporary English

Media) [Lingvokul'turnyj koncept $F A S H I O N$ kriz' pryzmu religijnoi' konceptosfery (na materiali suchasnyh anglomovnyh mediaresursiv)] (in Ukrainian) 


\title{
ЛИНГВОКУЛЬТУРНЫЙ КОНЦЕПТ FАSНION СКВОЗЬ ПРИЗМУ РЕЛИГИОЗНОЙ КОНЦЕПТОСФЕРЫ (НА МАТЕРИАЛЕ СОВРЕМЕННЫХ АНГЛОЯЗЫЧНЫХ МЕДИАРЕСУРСОВ)
}

\author{
Крисальная Юлиана Вячеславовна, yuliana.krysalna@gmail.com \\ ассистент \\ Киевский национальний университет имени Тараса Шевченко, \\ Институт филологии
}

\begin{abstract}
Мода как знаковая система изадавна воспринималась как неотъемлемая часть коммуникации. С развтием общества влияние моды, в частности, на мировоззренческие установки усиливается. В статье представлено развитие взаимовлияния концептов FASHION и RELIGION, сделана попытка сопоставления их как двух мировоззренческих систем. Обозначены вербальные и невербальные апеллячии к религиозным концептам в репрезентациях лингвокультурного концепта FASHION на современных англоязычных медиаресурсах. Особое внимание направлено на християнськую традищию как культурообразующую для английского языка. Обозначены некороторые репрезентации мусульманских религиозных концептов дискура моды как новые элементы массовой культуры современного англоязычного общества. В статье проанализировано изменение отношения $\kappa$ моде, начиная от библейских текстов до современных фэшн-изданий. В качестве материалов исследовании, кроме теста Библии в редакичи King James Bible, были использованы статьи современных модных журналов, сайты известных брендов и домов моды, тексты релизов и описаний модних коллекций, тексты популярних новостных порталов в разделах Blogs, Society, Culture и проч., а также для диахронической перспективы использовались тексты англоязычных авторов периода Средневековья и эпохи Возрождения. В исследовании рассмотрены современные аксиологические сдвиги в культуре и модном дискурсе, представлена широкая палитра иллюстративного материала. Определены такие основные этапь актуализации репрезентаций концепта FASHION, как SHAME - FAST, GRIEF AND SORROW - POWER - VICE - FREEDOM - IDENTITY - RELIGION. Результать исследования показали высокий уровень когнитивной модифицированности конщепта FASHION, установлено наличие антонимической противоположности первоначального и актуального состава ядра кониепта FASHION в религиозном аспекте.
\end{abstract}

Ключевые слова: кониепт FASHION, концепт RELIGION, религиозный концепт, когнитивная модификация.

Актуальні проблеми мовознавства [Актуальные проблемы языкознания]

(C) Крисальна Ю. В.[Крисальная Ю. В.], yuliana.krysalna@gmail.com Лінгвокультурний концепт FASHION крізь призму релігійної концептосфери (на матеріалі сучасних англомовних медіаресурсів) [Лингвокультурный концепт FASHION сквозь призму религиозной концептосферы (на материале современных англоязычных медиаресурсов)] (Українською/ На укр. яз) 


\title{
THE CONCEPT FASHION WITHIN THE COGNITIVE FRAMEWORK OF RELIGION (BASED ON CONTEMPORARY ENGLISH MEDIA)
}

\author{
Krysalna Y., yuliana.krysalna@gmail.com \\ Assistant Prof. \\ Taras Shevchenko National University of Kyiv, \\ Institute of Philology
}

The paper highlights the peculiarities of mutual interference between concepts FASHION and RELIGION. The study represents an attempt to compare fashion and religion as two systems of worldview. Verbal and non-verbal appeals to religious concepts within the scope of representations of concept FASHION in contemporary English media are being outlined. Special emphasis is put on Christian tradition as the cultural foundation of the English language. The paper briefly touches the problem of Muslim concepts' representations in fashion discourse as an essential part of contemporary English massculture. The change in perception of fashion from the Bible times to contemporary fashion magazines is being studied. The practical dimension of the research includes texts of King James Bible, articles extracted form modern fashion magazines, sites of well-known fashion brends, releases of fashion collections, texts of news portals especially from such columns as society, culture, blogs. The diachronic perspective is represented by the texts of English authors from the Middle Ages and the Rennaisance period. The study pinpoints axiological shifts in culture and fashion discourse. Such key stages of manifestation of various representations of the concept FASHION as SHAMEFAST, GRIEF AND SORROW - POWER - VICE - FREEDOM - IDENTITY - RELIGION were highlighted. The results of the study show a high level of cognitive modification of the concept FASHION, antonymic relations between the primary and current kernel parts of this concept are shown in religious aspect.

Key words: concept FASHION, concept religion, religious concept, cognitive modification.

Аксіологічна еклектика, когнітивна ризомність та релятивізм $\epsilon$ невід'ємними рисами сучасної епохи пост-пост-модерну. Із розвитком технологій комунікативний простір дедалі яскравіше виступає сприятливим середовищем для когнітивних альтернацій. У дослідженні представлено спробу розглянути генезу лінгвокультурного концепту FASHION у 
співвідношенні із релігійними аксіологічними домінантами та їх когнітивними модифікаціями.

Метою дослідження є встановлення віх когнітивних зсувів у процесі розвитку лінгвокультурного концепту FASHION в англійській мові та визначення їх релігійних факторів.

Мета дослідження визначає наступні завдання:

- проаналізувати зміни у перцепції лінгвокультурного концепту FASHION у діахронічному аспекті;

- дослідити релігійний компонент перцептивних зсувів у генезі лінгвокультурного концепту FASHION;

- означити вербальні та невербальні апеляції до релігійних концептів у репрезентаціях лінгвокультурного концепту FASHION на сучасних англомовних медіаресурсах.

Актуальність дослідження зумовлена високою частотністю когерентних референцій між репрезентаціями лінгвокультурного концепту FASHION та апеляціями до релігійних концептів.

Об'єктом дослідження $є$ взаємовплив лінгвокультурного концепту FASHION та релігійних концептів в англійській мові.

Предметом дослідження $\epsilon$ релігійна складова репрезентацій лінгвокультурного концепту FASHION у медіа.

У книзі «Система моди: статті з семіотики культури» Р. Барт звертає увагу на те, що кожна річ у світі моди має три різних структури: технологічну, іконічну та вербальну. Розповсюдження моди значною мірою засноване на діяльнісному перетворенні: здійсненні переходу від технологічної структури до іконічної та вербальної. Таке перетворення відбувається за допомогою операторів - «шифтерів». Р. Барт розрізняє три види «шифтерів»: від реальності до образу, від реальності до мови і від образу до мови [1, с. 40-41].

Таке твердження суголосне із визначенням лінгвокультурного концепту, за якого це - «багатомірне смислове утворення, в якому виділяються ціннісна, образна і понятійна сторони» [2, с. 5].

У сучасному медіапросторі було відстежено такі репрезентації лінгвокультурного концепту FASHION, як identity, glamour, style, lifestyle, clothing and accessories, trend, brand, advertising, popularity тощо. 
«Соціологія моди цілком звертається до реального одягу, а семіологія - до комплексу колективних уявлень. Тому використання мовної струтури призводить не до соціології а до соціологіки, постульованої Дюркгеймом та Моссом; завдання модного опису - не тільки пропонувати зразок для реального копіювання, але й перш за все широко розповсюджувати моду як смисл» [1, с. 44]. Саме смислотворча функція моди є полем найбільшого перетину концептів FASHION i RELIGION.

«Будучи концептом-регулятивом, мода регулює різні відношення і стосунки між спільнотами, групами людей та окремими особами. Як соціокультурний концепт мода відображається у лінгвокультурах і дозволяє розкрити особливості мовної свідомості і комунікативної поведінки носіїв цих культур» [6, с. 18].

У дисертаційному дослідженні «Лінгвоаксіологічні характеристики сучасного дискурсу моди» А. Р. Аркелова доводить аксіологічну природу дискурсу моди [7].

Релігія як система смислів пропонує власне потрактування багатьох нерелігійних концептів та відповідне ставлення до них. У дослідженні здебільшого розглядалась християнська релігійна традиція, як історично питома для англомовного простору та іслам як релігія, що швидко поширюється в сучасному англомовному світі.

Так, у релігійній парадигмі перші згадки про одяг у Біблії зустрічаються в контексті сорому та покарання - shame and punishment. And the eyes of them both were opened, and they knew that they were naked; and they sewed fig leaves together, and made themselves aprons[Genesis 3:7 KJB] (Мал. 1, 2). Адам і Єва самі створюють собі одяг, усвідомивши свою оголеність.

Згодом, при вигнанні із Едему, Бог створює для них шкіряний одяг Unto Adam also and to his wife did the LORD God make coats of skins, and clothed them [Genesis 3:21 KJB]. Деякі дослідники стверджують, що йдеться про надання тілесності, нового матеріального стану як результат гріхопадіння. Таку думку потверджує перелік божих покарань, які містять прямі комісиви щодо саме матеріальних, тілесних страждань Адама та його дружини: болісне народження дітей Unto the woman he said, I will greatly multiply thy sorrow and thy conception; in sorrow thou shalt bring forth children; and thy desire shall be to thy husband, and he shall rule over thee 
[Genesis 3:16 KJB];необхідність їжі та складне іï добування cursed is the ground for thy sake; in sorrow shalt thou eat of it all the days of thy life; 18 Thorns also and thistles shall it bring forth to thee; and thou shalt eat the herb of the field; піт і смерть як прояви тілесного страждання 19 In the sweatof thy face shalt thou eat bread,till thou return unto the ground; for out of it wast thou taken: for dust thou art, and unto dust shalt thou return.

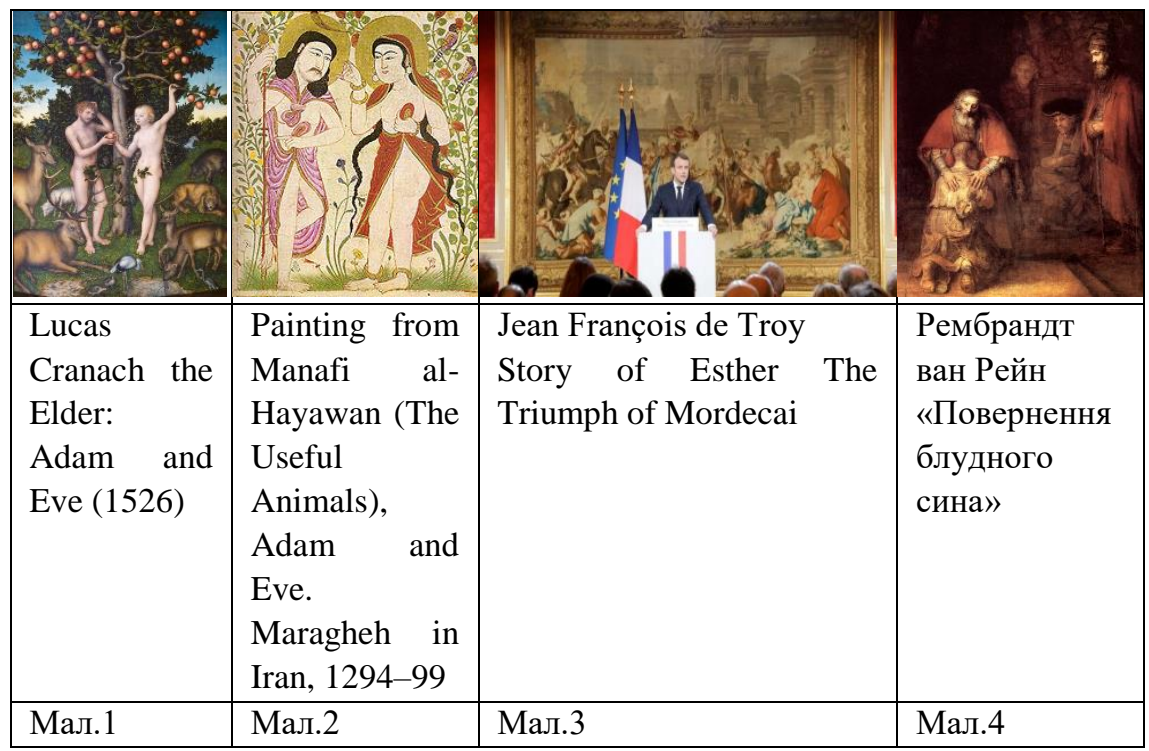

Необхідність одягу саме у контексті сорому також потверджує історія Ноя 21 And he drank of the wine, and was drunken; and he was uncovered within his tent. 22 And Ham, the father of Canaan, saw the nakedness of his father, and told his two brethren without. 23 And Shem and Japheth took a garment, and laid it upon both their shoulders, and went backward, and covered the nakedness of their father; and their faces were backward, and they saw not their father's nakedness. 24 And Noah awoke from his wine, and knew what his younger son had done unto him [Genesis 9:21-27 KJB].

Актуальні проблеми мовознавства [Актуальные проблемы языкознания]

(C) Крисальна Ю. В.[Крисальная Ю. В.], yuliana.krysalna@gmail.com Лінгвокультурний концепт FASHION крізь призму релігійної концептосфери (на матеріалі сучасних англомовних медіаресурсів) [Лингвокультурный концепт FASHION сквозь призму религиозной концептосферы (на материале современных англоязычных медиаресурсов)] (Українською/ На укр. яз) 
Споглядання оголеності батька призвело до прокляття Хама та усіх його нащадків. 25 And he said, Cursed be Canaan; a servant of servants shall he be unto his brethren. Тоді як поважливе ставлення до батька та прикриття його сорому, принесли вічне благословення Сіму та Іафету 26 And he said, Blessed be the LORD God of Shem; and Canaan shall be his servant. 27 God shall enlarge Japheth, and he shall dwell in the tents of Shem; and Canaan shall be his servant[Genesis 9:21-27 KJB].

Наступним етапом у біблійному потрактуванні одягу є маніфестації жалоби, жертвування комфортом і зручностями як результат розпуки та каяття (FAST, GRIEF AND SORROW).

Основними репрезентаціями цього аспекту є розривання одягу renting (toring) of the clothes, вдягання лахміття putting on a sackcloth, посипання пилом та попілом dust, ashes, прилюдне каяття або навпаки повне усамітнення для молитви. When Mordecai perceived all that was done, Mordecai rent (tore) his clothes, and put on sackcloth with ashes, and went out into the midst of the city, and cried with a loud and a bitter cry[Esther 4:1 KJB]. And Joshua rent his clothes, and fell to the earth upon his face before the ark of the LORD until the eventide, he and the elders of Israel, and put dust upon their heads.Joshua 7:6 So the people of Nineveh believed God, and proclaimed a fast, and put on sackcloth, from the greatest of them even to the least of them [Jonah 3:5 KJB].

Нового акценту у потрактуванні одяг набуває із входженням біблійного народу у тісні стосунки із можновладцями та правителями. Це можна прослідкувати в історії Йосифа And Pharaoh took off his ring from his hand, and put it upon Joseph's hand, and arrayed him in vestures of fine linen, and put a gold chain about his neck [Genesis 41:42 КJB]. Одяг постає як маніфестація статусу, сили та могутньості. Зокрема, крім одягу з якісних дорогих матеріалів (vestures of fine linen) як показника статусу, актуалізуються значення аксесуарів: важливим символом влади є перстень (ring), золоті прикраси (a gold chain).

В офіційній резиденції президента Франції -Слисейському палаці в Парижі $є$ величний гобелен Тріумф Мордохея (Мал. 3) як репрезентація слави, влади та перемоги над ворогами.

В книзі Естер подія, зображена на цьому гобелені, описана так: For the man whom the king delighteth to honour, 8 Let the royal apparel be brought which the king useth to wear, and the horse that the king rideth upon, and the crown 
royal which is set upon his head: 9 And let this apparel and horse be delivered to the hand of one of the king's most noble princes, that they may array the man withal whom the king delighteth to honour, and bring him on horseback through the street of the city, and proclaim before him, Thus shall it be done to the man whom the king delighteth to honour [Esther 6:5-9, КJB].

Остаточну перемогу Мардохея над Аманом також супроводжують символічні елементи вбрання: 15 And Mordecai went out from the presence of the king in royal apparel of blue and white біло-синій царський одяг, and with a great crown of gold, золота корона and with a garment of fine linen and purple вбрання із якісних тканин та оздоблене пурпуром and the city of Shushan rejoiced and was glad [Esther 8:15 KJB].

Елементи становлення репрезентації DISTINCTION AND POWER лінгвокультурного концепту FASHION також можна відстежити у Новому заповіті. Так, в притчі про блудного сина (The parable of the prodigal son) y відповідь на повернення та щиросердне каяття блудного сина And the son said unto him, Father, I have sinned against heaven, and in thy sight, and am no more worthy to be called thy son. Батько наказує дати йому найкраще вбрання та взуття - як показник статусу, добробуту та захищеності і перстень, як символ влади, 22 But the father said to his servants, Bring forth the best robe, and put it on him; and put a ring on his hand, and shoes on his feet: 23 And bring hither the fatted calf, and kill it; and let us eat, and be merry: 24 For this my son was dead, and is alive again; he was lost, and is found. And they began to be merry [Luke 15:20-24, KJB].

Тож в ході дослідження було визначено, що репрезентаціями FASHION as POWER в біблійних текстах виступали зокрема такі лексеми: Ring, the best robe, royal apparel, great crown of gold, vestures of fine linen, a gold chain.

Іншою репрезентацією FASHION у біблійних текстах $€$ REVERENCE. "You shall make holy garments for Aaron your brother, for glory and for beauty. "You shall speak to all theskillful persons whom I have endowed with the spirit of wisdom, that they make Aaron's garments to consecrate him, that he may minister as priest to Me [Exodus 28:1-6 KJB]. У книзі Вихід Бог дає детальні настанови про вбрання первосвященика, у яких підкреслюється важливість якісного оздоблення та величності вбрання на знак пошани священника та народу до

Актуальні проблеми мовознавства [Актуальные проблемы языкознания] (C) Крисальна Ю. В.[Крисальная Ю. В.], yuliana.krysalna@gmail.com Лінгвокультурний концепт FASHION крізь призму релігійної концептосфери (на матеріалі сучасних англомовних медіаресурсів) [Лингвокультурный концепт FASHION сквозь призму религиозной концептосферы (на материале современных англоязычных медиаресурсов)] (Українською/ На укр. яз) 
Бога та для виклику поваги до його служителя "You shall take the garments, and put on Aaron the tunic and the robe of the ephod and the ephod and the breastpiece, and gird him with the skillfully woven band of the ephod; and you shall set the turban on his head and put the holy crown on the turban [Exodus 29:5-6 KJB].

Втім ще одним оприявленням лінгвокультурного концепту FASHION $\epsilon$ VICE. Так, у Книзі пророка Ісаї знаходимо прокляття донькам Сіону за їх надмінність, погорду: 16 Moreover the LORD saith, Because the daughters of Zion are haughty, and walk with stretched forth necks and wanton eyes, walking and mincing as they go, and making a tinkling with their feet [Isaiah 3:16]. Відзначимо, що саме в цьому фрагменті представлено опис подібний до азів модельного бізнесу. Наприклад, на сайті www.seventeen.com знаходимо Tyra Banks's Modeling Tips-поради майбутнім моделям: Do not be a "no-neck monster." Try to elongate your neck for maximum extension. Do not stare aimlessly when posing. Create intensity for the camera through your eyes. Smize (smile with your eyes)! Do not slouch on the runway; pretend you have a wire through your spine that is pulling you up to the ceiling.Do not be forgettable. Make an impression by showing your distinctive personality [21].

Також пророк засуджує надмірне занурення у матеріальне, що виражає та підкреслює довгим детальним переліком різноманітних прикрас, оздоблень, аксесуарів, одягу: 17 Therefore the Lord will smite with a scab the crown of the head of the daughters of Zion, and the LORD will discover their secret parts. 18 In that day the Lord will take away the bravery oftheir tinkling ornaments about their feet, and their cauls, and their round tires like the moon, 19 The chains, and the bracelets, and the mufflers, 20 The bonnets, and the ornaments of the legs, and the headbands, and the tablets, and the earrings, 21 The rings, and nose jewels, 22 The changeable suits of apparel, and the mantles, and the wimples, and the crisping pins, 23 The glasses, and the fine linen, and the hoods, and the vails [Isaiah 3:17-23].

В англомовній літературі подібний прийом зустрічається у «Приборканні норовливої» В. Шекспіра, але вже у іронічному контексті:

Will we return unto thy father's house

And revel it as bravely as the best,

With silken coats and caps and golden rings,

With ruffs and cuffs and farthingales and things,

Actual Problems of Linguistics [Aktual'ni problemy movoznavstva]

(C) Krysalna Y. [Krysal'na Ju.], yuliana.krysalna@gmail.com

The Concept FASHION within the Cognitive Framework of Religion (Based on Contemporary English

Media) [Lingvokul'turnyj koncept FASHION kriz' pryzmu religijnoi' konceptosfery (na materiali suchasnyh anglomovnyh mediaresursiv)] (in Ukrainian) 
With scarves and fans and double change of brav'ry,

With amber bracelets, beads, and all this knav'ry.

What, hast thou dined? The tailor stays thy leisure

To deck thy body with his ruffling treasure[17, Act IV scene 3 line 55].

Довгий детальний перелік «благ» батьківського дому має на меті протиставлення дійсності в якій живуть Петруччо і Катаріна, підкреслення малозначності колишніх інтересів Катаріни (ruffling treasure). Можна припустити, що наведений фрагмент містить саме біблійну конотацію, та апелює до аналізованого тексту, у контексті шекспірівської доби, оскільки Біблія була на той час одним із найбільш знаних текстів у суспільстві.

Перелік у книзі пророка Ісаї завершується протиставними конструкціями, що надають емфази та більшого драматизму пророкуванню: 24 And it shall come to pass, that instead of sweet smell there shall be stink; and instead of a girdlea rent; and instead of well set hairbaldness; and instead of a stomacher a girding of sackcloth; and burning instead of beauty [Isaiah 3:16 KJB]. Так, згідно пророцтва, зміни, які спричиняє занурення у світ моди та краси із акцентом на індивідуальність, пріоритет зовнішнього над внутрішнім, матеріального на духовним, призводять до суттєвих особистісних змін і, зрештою, до повного занепаду особистості як у духовному так i матеріальному плані.

Саме у Шекспірівську добу можна відстежити розвиток нового ставлення до моди. На противагу середньовічному моралістичному відстороненню від Буденного і спрямуванню до Вічного, у суспільстві, популяризується концепт моди. Актуалізація концепту тісно пов'язана iз статутизацією: у відомому документі “The Royal Proclamation on the subject of 'excesse of apparel” від 15 червня 1574 було чітко встановлено статусні особливості одягу та прикрас.

Це був не перший закон, що встановлював обмеження та соціальну стратифікацію щодо одягу (перший Apparel act 1363 в період правління Едварда I).

На противагу аристократичному дорогому вбранню та високій увазі стратифікації за вбранням, у суспільстві були присутні постсередньовічні настрої. Так, у памфлеті Anatomy of abuses (1583), Філіп Стаббс зазначає: 'Beautiful garments are the devilles nettes to intangle poore soules in' [18] -

Актуальні проблеми мовознавства [Актуальные проблемы языкознания]

(C) Крисальна Ю. В.[Крисальная Ю. В.], yuliana.krysalna@gmail.com Лінгвокультурний концепт FASHION крізь призму релігійної концептосфери (на матеріалі сучасних англомовних медіаресурсів) [Лингвокультурный концепт FASHION сквозь призму религиозной концептосферы (на материале современных англоязычных медиаресурсов)] (Українською/ На укр. яз) 
“Гарне вбрання - це пастка диявола, щоб ловити бідні душі”. Такі засудливі висловлювання актуалізують 'VICE' як одну із складових концепту "FASHION".

У п'єсі Томаса Томкінса 'Lingua, or the Combat of the Tongue and the Five Senses for Superiority' (1604) знаходимо такі рядки: 'A ship is sooner rigged that a gentlewoman made ready'[19] - “Скоріш готовий корабель відплисти, ніж знатна пані пери ніж вийти в світ”. Задокументована у цих рядках звичка до довгої підготовки та наряджання, підтверджує актуалізацію моди в англомовному суспільстві того часу, зміну загального іiі сприйняття 3 негативного на позитивне.

В сучасному англомовному просторі протягом дослідження були відстеженні нові тенденції розвитку концепту FASHION, дедалі FREEDOM все більше актуалізується як одна із його ключових складових.

Зокрема, це має прояви у крос-культурній комунікації, на зламі чи перетині різних культурних та релігійних традицій. Наприклад, у виданні The Independent примусове зобов'язання усіх жінок носити хіджаб в Ірані та заборона у Франції традиційного мусульманського одягу для купання (Мал. 5) - буркіні (бленд слів burka - назва довгого традиційного мусульманського одягу для жінок та bikini - назва білизни) висвітлюється так: Enforced hijab in Iran and burkini ban in France are both about one issue only, says My Stealthy Freedom founder. The biggest social movement against enforced hijab in Iran and the banning of burkinis on local French beaches both demonstrate one key issue at the centre of each - the freedom of choice [16].Характерними для концепту FREEDOM $\epsilon$ репрезентації бінарних опозицій ban - choice, enfrorced-free та ін.

Інша складова близька до FREEDOM - IDENTITY також стає важливою у реперезентаціях концепту FASHION. У виданні The Daily Mail до 50 річниці створення ляльки Барбі опубліковане інтерв'ю власниці найбільшої колекції Барбі у Сполученому Королівстві, Анджели Еліс. В якому вона коментує створення нової лінії ляльок Барбі у бурках та хіджабах. 'I think this is really important for girls, wherever they are from they should have the opportunity to play with a Barbie that they feel represents them' (Мал.6) [20].

Як повідомляє журнал Woman Emirates у 2017 році учасниця конкурсу краси в штаті Мейн (США) Хаміда Ахмед виступала у хіджабі та бурці (Мал.7). 
"I competed in Miss Maine as the first Muslim girl with a Hijab. I slayed my hijab. "I want to inspire other girls to feel beautiful, confident and follow their dreams no matter where they're from." "Representation is important," she told the site. "I didn't take the crown, but it was an amazing experience"[12].

Характерними репрезентаціями англомовного концепту IDENTITY, що наразі перетинаються із концептом FASHION $є$ лексеми, що спонукають до дій та визнання людиною себе як цінності I want to inspire, підкреслення виходу за встановлені межі представниками певних соціальних, релігійних груп, I competed in Miss Maine as the first Muslim girl with a Hijab, потвердження глобалізації та міксу культур по matter where they are from, встановлення культурного, расового, соціального різноманіття як цінності representation is important.

Серед інших тенденцій слід відзначити, що в англомовному медіапросторі та індустрії моди активно розвивається поєднання релігії та моди. Зокрема, дедалі зростає кількість нейтральних повідомлень про релігійні події у стилістиці опису світських хронік, із зміщенням акценту 3 таїнства або служби на деталі модних образів їх зіркових учасників.

Так, The Daily Express повідомляє про наближення дня вінчання Принца Гаррі та Меган Маркл: The Royal Wedding dress code for guests attending the ceremony is uniform or a morning coat or lounge suit for the men. Women are asked to wear a day dress, with stipulations they must wear a hat. Kate is a fan of headwear, and chose a stunning nude creation for the biggest wedding of 2017, that of her sister, Pippa Middleton. The sculpted rose-topped hat was by milliner Jane Taylor, and Kate may turn to the designer for Meghan and Harry's wedding. Speculation is rife over who will design Meghan's wedding dress [14].

Яскравою тенденцією сучасної моди є андорогінність, маскулінізація фемінного та фемінізація маскулінного у форматі houte couture, що є прямим порушенням настанови книги Второзаконня про заборону чоловікам вдягати жіночий одяг і навпаки. 5 The woman shall not wear that which pertaineth unto a man, neither shall a man put on a woman's garment: for all that do so are abomination unto the LORD thy God[Deuteronomy 22:5, KJB].

Так, модне видання Vogue описує колекцію Тома Брауна осінь-2018 (Мал. 8) It's no accident that Browne chose to render his collection in 50 shades of gray flannel, dare we say the very fabric of the patriarchy. The designer has

Актуальні проблеми мовознавства [Актуальные проблемы языкознания]

(C) Крисальна Ю. В.[Крисальная Ю. В.], yuliana.krysalna@gmail.com Лінгвокультурний концепт FASHION крізь призму релігійної концептосфери (на матеріалі сучасних англомовних медіаресурсів) [Лингвокультурный концепт FASHION сквозь призму религиозной концептосферы (на материале современных англоязычных медиаресурсов)] (Українською/ На укр. яз) 
made toying with the line that traditionally divides a man's and a woman's wardrobe a subtle art form; in Browne's world, skirts and suits are essentially gender-neutral [15].

Питома для християнської традиції патріархальність дедалі відходить на периферію із актуалізацією сильних фемінних проявів. В моді це проявляється в образах чоловіків на підборах, у платтях тощо.

So when a troop of men in heels and fluffy dog heads came bounding down the runway-to the sounds of "Who Let the Dogs Out" no less!-the audience all but raised a cheer. Browne's male models were on a short leash quite literally, under the watchful eye of a stunning mistress dressed in a gown fit for an 18th-century queen. In the age of \#MeToo and \#TimesUp, when power structures in the workplace are undergoing a seismic shift, the symbolism was potent [15].

Резонансним прикладом цього тренду була поява чорного актора та співака Біллі Портера на церемонії Оскар у довгій оксамитовій сукнісмокінгу зі шлейфом “This look was interesting because it's not drag. I'm not a drag queen, I'm a man in a dress," Porter told Vogue magazine. Porter explained to Vogue that even though people might not agree with other's choices, it's important to remember to respect each other"[11]. - “Я не трансгендер, я - чоловік у сукні, і якщо люди не погоджуються з цим, вони все ж повинні поважати іншу думку." (Мал. 9).

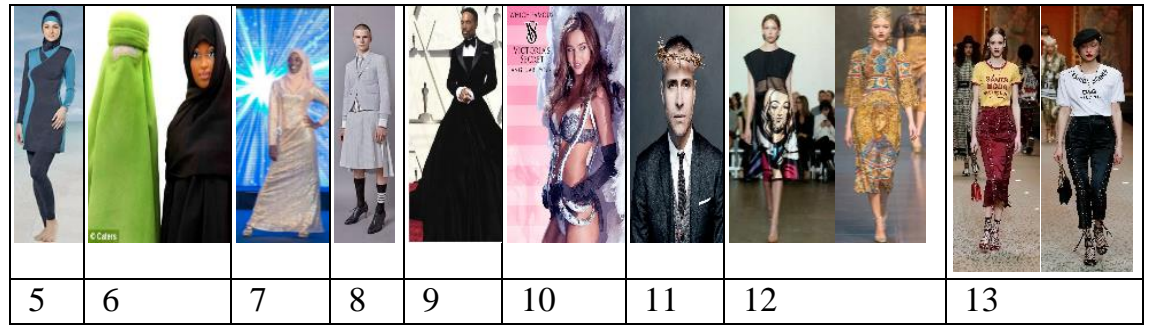

Цікавим є новий потужний тренд позиціонування самої моди як релігії. Незалежна журналістка, блогер Анна Баттіста зазначає 'Besides, it is not rare for the semantic field of religion to be employed in fashion with designers being considered as prophets, while certain magazines are dubbed 
as fashion's "Bible", and style is the one and only virtue, replacing the teleological virtues of faith, hope and love' [10]. Справді, у семантичному полі Fashion 3'явився значний масив релігійної лексики, так моделі відомого бренду жіночої білизни позиціонуються як Victoria's Secret Angels (Мал.10), журнал Cosmopolitan називає себе fashion Bible, Dolce\&Gabbana проголошують, що стиль - єдина чеснота, а відомий законодавець світу моди Карл Лагерфельд неодноразово у багатьох виданнях фігурує як fashion missionary, fashion Pope, та є основним героєм документального фільму-інтерв'ю Mode als Religion - Мода, як релігія.

Ever since we learned that Karl Lagerfeld had declared himself 'Pope of Fashion' in an upcoming German documentary, we've been finding it difficult to shake the mental image of the tireless designer in full religious habit [13].

Ірландський випуск видання the Independent повідомляє, що продюсер і автор фільму Mode als religion заявила, що їй відомі нейрологічні дослідження які потверджують, що емоційні реакції мозку католицького священника та мозку фешеніста на їх "релігійні подразники" однакова. Martina Neuen, even spoke to a neurologist proving that the emotional reactions of the brains of a Catholic priest and a fashionista are the same when facing their own "religions" [22].

Новим кроком розвитку взаємовпливу між концептами RELIGION i FASHION можна назвати блюзнірське використання релігійних образів (Мал.11), зокрема ікон, мозаїк, скульптур у колекціях одягу. Наприклад використання хрестів у якості підборів (D\&G fall 2016), зображення ікон нижче лінії талії (D\&G fall 2018, Karla Spetic, 2017) (Мал. 12), провокативна фотосесія з образом П'єти (Givenchy) тощо.

Так, описуючи нову колекцію з релігійними конотаціями від Сари Бартон, журнал Vogue згадує модний показ у колишній церкві представлений брендом Alexander McQueen: From those early heretical spectacles in deconsecrated churches, religiosity has always been a McQueen signature, but Sarah Burton added extraordinary new layers with her pre-fall collection for the label. For anyone not versed in the intricacies of Anglican worship, all one needed to know was that Burton wanted to evoke англомовних медіаресурсів) [Лингвокультурный концепт FASHION сквозь призму религиозной концептосферы (на материале современных англоязычных медиаресурсов)] (Українською/ На укр. яз) 
the humility and purity of low-church Anglicanism, rather than its incenseand-ritual high-church counterpart [9].

Яскравим прикладом реалізації тези «мода - це релігія» стала колекція осінь-зима 2018-2019 Dolce \& Gabbana "Fashion devotion" (Мал. 13) Fashion sinner' and 'D\& G devotion' were graphics seen on the $t$ shirts, claiming the brand to be a religion of its own. "Fashion is not work, fashion is devotion," Dolce said. "You live, sleep and eat with fashion, you never stop thinking about it and you love it with all your heart" [24]. Серед принтів колекції - написи Santa Moda, Fashion Sinner, Fashion Devotion, серед одягу - embroidered cross coats, monk furs, cardinal jackets and papal robe inspired inlaid skirts, parade like a procession, [23] серед аксесуарів - сумочки у вигляді кадильниць. Так, релігійна, здебільшого християнська традиція, отримує нові форми актуалізації, зокрема шляхом профанативних та дискредитивних модифікацій концепту RELIGION.

Протягом дослідження було визначено, що релігійний вимір концепту FASHION пройшов такі етапи становлення, як SHAME - FAST, GRIEF AND SORROW - POWER - VICE - FREEDOM - IDENTITY RELIGION. Це потверджує значний рівень когнітивної модифікованості концепта у релігійній ретроспективі, оскільки початковий етап FASHION as SHAME категоріально антонімічний останньому FASHION AS RELIGION.

\section{Література:}

1. Барт, Р. Система моди: статьи по семиотике культуры (Москва, 2003),512,доступ http://yanko.lib.ru/books/cultur/bart-sistema_modu.pdf.

2. Карасик, В. И., Красавский, Н. А., Слышкин, Г. Г. Лингвокультурная концептология - Парадигма (Волгоград, 2009), 116, доступ https://elibrary.ru/item.asp?id=23754421

3. Лола, Г. Н. «Дискурс моды: от нарративного коко.на к рекламному посланию.»Мода в контексте культуры 3(2008): 83-88.

4. Михайловская, И. Н., Чубина, Е. А. Особенности языка англоязычных СМИ, доступ https://scienceforum.ru/2013/article/2013007326.

5. Норбоева, Т. Б. «Понятийный анализ моды как феномена культуры.»Общество. Среда. Развитие 3 (2011): 159-161.

Actual Problems of Linguistics [Aktual'ni problemy movoznavstva]

(C) Krysalna Y. [Krysal'na Ju.], yuliana.krysalna@gmail.com

The Concept FASHION within the Cognitive Framework of Religion (Based on Contemporary English

Media) [Lingvokul'turnyj koncept FASHION kriz' pryzmu religijnoi' konceptosfery (na materiali suchasnyh anglomovnyh mediaresursiv)] (in Ukrainian) 
6. Чурсина, О. В. «Лингвокультурниый концепт «мода» в языковом сознании и коммуникативном поведении.»(Дис. канд. филол. наук, Волгоград, 2010), доступ $\quad$ https://docplayer.ru/53149651-Lingvokulturnyi-koncept-moda-vyazykovom-soznanii-i-kommunikativnom-povedenii.html

7. Аракелова, А. Р. «Лингвоаксиологические характеристики современного англоязычного дыскурса моды.»(Дис. канд. филол. наук,Пятигорск, 2017), доступ http://www.pglu.ru/upload/iblock/114/Dissertatsiya_Arakelovoy_A.R..pdf

8. King James Bible, доступ https://biblehub.com/kjv/

9. Blanks, Tim.«Pre-Fall 2013Alexander McQueen.»Vogue (16 January, 2013), доступ https://www.vogue.com/fashion-shows/pre-fall-2013/alexander-mcqueen

10. Battista, A. Fashioning Religion: How a Fake Search for the Spiritual Became an Unfashionable Trend (August, 29 2013), доступ https://irenebrination.typepad.com/ irenebrination_notes_on_a/2013/08/fashioning-religion.html

11. Hanno, Donna.'I'm a man in a dress': Billy Porter wears tuxedo gown to 2019 Oscars, доступ https://www.ctvnews.ca/entertainment/i-m-a-man-in-a-dress-billy-porterwears-tuxedo-gown-to-2019-oscars-1.4311016

12. Pudney, H. This former refugee wore a hijab and burkini in a US beauty pageant/ Harriet Pudney. - Woman Emirates - 26 December 2017, доступ http://emirateswoman.com/this-former-refugee-wore-a-hijab-and-burkini-in-a-usbeauty-pageant/

13. Karl, Lagerfeld.Fashion Pope $\quad-\quad$ Elle (29 July 2013), доступ https://www.elle.com/uk/fashion/news/g2816/karl-lagerfeld-fashion-pope-cartoonpictures-alexsandro-palombo/

14. O’Callaghan, Lauren Royal.«Wedding: dress code means Kate Middleton will definitely wear THIS item.»The Daily Express(31 March, 2018), доступ https://www.express.co.uk/life-style/style/939675/royal-wedding-dress-code-katemiddleton

15. Nnadi, Chioma.Fall 2018 ready-to-wear Thom Browne, доступ https://www.vogue.com/fashion-shows/fall-2018-ready-to-wear/thom-browne

16. Saul, Heather.«Enforced hijab in Iran and burkini ban in France are both about one issue only, says My Stealthy Freedom founder.»The Independent(20 August 2016), доступ https://www.independent.co.uk/news/people/burkini-ban-france-beacheshijab-iran-a7201011.html

17. Shakespeare,W.The taming of the Shrew, доступ http://shakespeare.mit.edu/taming_shrew/taming_shrew.4.3.html

18. Stubbes, Philip.The Anatomy of Abuses, доступ https://www.bl.uk/collectionitems/the-anatomy-of-abuses-by-philip-stubbes-1583

19. Tomkins, T. Lingua, or, The combat of the tongue, and the five senses for superiority a pleasant comedy, доступ https://quod.lib.umich.edu/e/eebo/ $\underline{\mathrm{A} 62894.0001 .001}$ ? view $=$ toc 
20. World-famous doll gets a makeover to go under the hammer for 50th anniversary, доступ https://www.dailymail.co.uk/news/article-1229760/Its-Barbie-burka-Worldfamous-doll-gets-makeover-hammer-50th-anniversary.html\#ixzz5Df95jIr9

21. Tyra Banks's Modeling Tips, доступ https://www.seventeen.com/ fashion/news/a16797/tyra-banks-modeling-tips/

22. «Popes aren't chic" - Lagerfeld.»The Independent, Ireland (26 July 2013), доступ https://www.independent.ie/style/fashion/popes-arent-chic-lagerfeld-29450529.html

23. «Fall- Winter 2018-2019 Dolce \&Gabbana Collection.»Vogue, доступ https://www.vogue.it/en/shows/show/collections-fall-winter-2018-19/dolce-egabbana?refresh ce

24. Fall-Winter 2018-2019 Dolce \& Gabbana Collection, доступ https://www.somethinghaute.com/dolce-gabbanas-fashion-devotion

\section{References:}

1. Bart, R. Sistema modi: stat'i po semiotike kul'tury(Moskva, 2003), 512, dostup http://yanko.lib.ru/books/cultur/bart-sistema_modu.pdf

2. Karasik, V. I., Krasavskij, N. A., Slyshkin, G. G. Lingvokul'turnaja konceptologijaParadigma (Volgograd, 2009), 116, dostup https://elibrary.ru/item.asp?id=23754421

3. Lola, G. N. «Diskurs mody: ot narrativnogo kokona k reklamnomu poslaniju.» Moda $v$ kontekste kul'tury 3 (2008): 83-88.

4. Mihaı̌lovskaja, I. N., Chubina, E. A. Osobennosti jazyka anglojazychnyh, dostup https://scienceforum.ru/2013/article/2013007326

5. Norboeva, T. B. «Ponjatiı̆nyı̆ analiz mody kak fenomena kul'tury.»Obshhestvo. Sreda. Razvitie 3(2011): 159-161.

6. Chursina, O. V. «Lingvokul'turniyj koncept «moda» v jazykovom soznanii i kommunikativnom povedenii.» (Dis. kand. filol. nauk, Volgograd, 2010), dostup https://docplayer.ru/53149651-Lingvokulturnyi-koncept-moda-v-yazykovomsoznanii-i-kommunikativnom-povedenii.html

7. Arakelova, A. R. «Lingvoaksiologicheskie harakteristiki sovremennogo anglojazychnogo dyskursa mody.» (Dis. kand. filol. nauk, Pjatigorsk, 2017), dostuphttp://www.pglu.ru/upload/iblock/114/Dissertatsiya_Arakelovoy_A.R..pdf

8. King James Bible, доступhttps://biblehub.com/kjv/

9. Blanks, Tim.«Pre-Fall 2013Alexander McQueen.» Vogue (16 January, 2013), доступ https://www.vogue.com/fashion-shows/pre-fall-2013/alexander-mcqueen

10. Battista, A. Fashioning Religion: How a Fake Search for the Spiritual Became an Unfashionable Trend (August, 29 2013), доступ https://irenebrination.typepad.com/ irenebrination_notes_on_a/2013/08/fashioning-religion.html

Actual Problems of Linguistics [Aktual'ni problemy movoznavstva]

(C) Krysalna Y. [Krysal'na Ju.], yuliana.krysalna@gmail.com

The Concept FASHION within the Cognitive Framework of Religion (Based on Contemporary English Media) [Lingvokul'turnyj koncept FASHION kriz' pryzmu religijnoi' konceptosfery (na materiali suchasnyh anglomovnyh mediaresursiv)] (in Ukrainian) 
11. Hanno, Donna. 'I'm a man in a dress': Billy Porter wears tuxedo gown to 2019 Oscars, доступ https://www.ctvnews.ca/entertainment/i-m-a-man-in-a-dress-billyporter-wears-tuxedo-gown-to-2019-oscars-1.4311016

12. Pudney, H. This former refugee wore a hijab and burkini in a US beauty pageant/ Harriet Pudney. - Woman Emirates - 26 December 2017 - Режим доступу: http://emirateswoman.com/this-former-refugee-wore-a-hijab-and-burkini-in-a-usbeauty-pageant/

13. Karl, Lagerfeld.Fashion Pope $\quad-\quad$ Elle (29 July 2013), доступ https://www.elle.com/uk/fashion/news/g2816/karl-lagerfeld-fashion-pope-cartoonpictures-alexsandro-palombo/

14. O’Callaghan, Lauren Royal. «Wedding: dress code means Kate Middleton will definitely wear THIS item.» The Daily Express (31 March, 2018), доступ https://www.express.co.uk/life-style/style/939675/royal-wedding-dress-code-katemiddleton

15. Nnadi, Chioma.Fall 2018 ready-to-wear Thom Browne, доступ https://www.vogue.com/fashion-shows/fall-2018-ready-to-wear/thom-browne

16. Saul, Heather. «Enforced hijab in Iran and burkini ban in France are both about one issue only, says My Stealthy Freedom founder.» The Independent(20 August 2016), доступ https://www.independent.co.uk/news/people/burkini-ban-france-beacheshijab-iran-a7201011.html

17. Shakespeare,W. The taming of the Shrew, доступ http://shakespeare.mit.edu/ taming_shrew/taming_shrew.4.3.html

18. Stubbes, Philip.The Anatomy of Abuses, доступ https://www.bl.uk/collectionitems/the-anatomy-of-abuses-by-philip-stubbes-1583

19. Tomkins, T. Lingua, or, The combat of the tongue, and the five senses for superiority a pleasant comedy, доступ https://quod.lib.umich.edu/e/eebo/ A62894.0001.001? view $=$ toc

20. World-famous doll gets a makeover to go under the hammer for 50th anniversary, доступ https://www.dailymail.co.uk/news/article-1229760/Its-Barbie-burka-Worldfamous-doll-gets-makeover-hammer-50th-anniversary.html\#ixzz5Df95jIr9

21. Tyra Banks's Modeling Tips, доступ https://www.seventeen.com/fashion/news/ a16797/tyra-banks-modeling-tips/

22. «Popes aren't chic" - Lagerfeld.»The Independent, Ireland (26 July 2013), доступ https://www.independent.ie/style/fashion/popes-arent-chic-lagerfeld-29450529.html

23. «Fall- Winter 2018-2019 Dolce \&Gabbana Collection.»Vogue, доступ https://www.vogue.it/en/shows/show/collections-fall-winter-2018-19/dolce-egabbana?refresh_ce=

24. Fall-Winter 2018-2019 Dolce \& Gabbana Collection, доступ https://www.somethinghaute.com/dolce-gabbanas-fashion-devotion/ 


\title{
ОСОБЛИВОСТІ ДАВНЬОГРЕЦЬКИХ ФРАЗЕОЛОГІЗМІВ IЗ КОМПОНЕНТОМ-ДЕНДРОНІМОМ
}

\author{
Лазер-Паньків Олеся Василівна, panlazer@ukr.net \\ канд. філол. наук, доц. \\ Київський національний університет імені Тараса Шевченка \\ Інститут філології
}

У статті викладено результати дослідження особливостей давньогрецьких фразеологічних одиниць із компонентом-дендронімом (видовою назвою дерева, назвою частини або плоду деревної рослини або їхніми дериватами). На основі лінгвокультурологічного та семантичного аналізу було здійснено характеристику їх внутрішньої форми. Це дало підстави стверджувати, щзо найбільший фразеотворчий потенціал у давньогрецькій мові має дендронім СМОКВА. Про те, наскільки широко вживаним у побуті еллінів було це дерево та його плоди, свідчить наявність у давньогрецькій мові окремих лексем на позначення певних його різновидів та частин. Досить чисельними є також ФО, які містять дендронім ДУБ, натомість дендроніми ЯБЛУНЯ, ОЛИВА, МИРТ, ЛАВР, ШОВКОВИЦЯ, СОСНА, МАСТИКОВЕ ДЕРЕВО, ТЕРЕН, ГРАНАТОВЕ ДЕРЕВО, КОРКОВЕ ДЕРЕВО та ГРУША вживаються значно рідше. Така кількісна асиметрія зумовлена особливостями їх використання еллінами у повсякденному житті. Найбільшу групу становлять ФО, у яких вживається саме видова назва дерева (а не частини дерева чи плоду). Проведене дослідження внутрішньої форми давньогрецьких ФО із компонентом-дендронімом дозволило окреслити когнітивні механізми творення вторинного значення. $62 \%$ ФО створені на основі метафоризації (за моделями “конкретне $\rightarrow$ абстрактне”, “рослина $\rightarrow$ людина”, “рослина $\rightarrow$ предмет”, “предмет $\rightarrow$ предмет”). Не мени чисельну групу становлять фразеологізми з компонентом-дендронімом, в основу яких покладено метафтонімію - складний когнітивний механізм поєднання метафори та метонімї (тип “метонімія всередині метафори” є значно продуктивнімим, ніж тип “метафора всередині метоніміі”). Наймени чисельними є ФО, основою творення яких є метонімія. Аналіз семантики давньогрецьких ФО із компонентомдендронімом дозволив виокремити наступні види мотиваційної основи цчих ФО: фізичні властивості дерев, їхніх частин та плодів, у тому числі пов'язані з досвідом 
їх практичного використання; практика використання дерев, їхніх частин та плодів у різноманітних ритуалах, обрядах та звичаях; історична подія, у якій було задіяне певне дерево чи його частина; характеристики частин дерев та плодів, пов'язані з вживанням їх у їжу; згадка про дерева у міфах та переказах.

Ключові слова: давньогрецькі фразеологізми, дендронім, лінгвокультурологічний аналіз, семантичний аналіз, внутрішня форма, метафора, метафтонімія, метонімія, мотивачійна основа.

\title{
ОСОБЕННОСТИ ДРЕВНЕГРЕЧЕСКИХ ФРАЗЕОЛОГИЗМОВ С КОМПОНЕНТОМ-ДЕНДРОНИМОМ
}

\author{
Лазер-Панькив Олеся Васильевна, panlazer@ukr.net \\ канд. филол. наук, доц. \\ Киевский национальный университет \\ имени Тараса Шевченко, \\ Институт филологии
}

В статье изложень результаты исследования особенностей древнегреческих фразеологических единиц с компонентом-дендронимом (видовым названием дерева, названием части или плода древесного растения или их дериватами). На основе их лингвокультурологического и семантического анализа была дана характеристика их внутренней формыл. Это позволило утверждать, что наибольшим фразеотворческим потенциалом в древнегреческом языке обладает дендроним СМОКОВНИЦА. О том, насколько широко использовалось в быту эллинов это дерево и его плоды, свидетельствует наличие в древнегреческом языке отдельных лексем для обозначения определенных его видов и частей. Достаточно многочисленнь также ФЕ, содержащие дендроним ДУБ, в то время как дендронимы ЯБЛОНЯ, ОЛИВА, МИРТ, ЛАВР, ШЕЛКОВИЦА, СОСНА, МАСТИКОВОЕ ДЕРЕВО, ТЕРН, ГРАНАТОВОЕ ДЕРЕВО, ПРОБКОВОЕ ДЕРЕВО И ГРУША используются значительно реже. Такая количественная асимметрия обусловлена особенностями их использования эллинами в повседневной жизни. Наибольшую группу составляют ФЕ, в которых употребляется именно видовое название дерева (а не части дерева или плода). Проведенное исследование внутренней формы древнегреческих ФЕ с компонентом-дендронимом позволило определить когнитивные механизмы создания вторичного значения. $62 \%$ ФЕ созданы на основе метафоризации (по моделям “конкретное $\rightarrow$ абстрактное”, “растение $\rightarrow$ человек”, “растение $\rightarrow$ предмет”, “предмет $\rightarrow$ предмет”). Не менее многочисленную группу составляют фразеологизмы с компонентом-дендронимом,

Актуальні проблеми мовознавства [Актуальные проблемы языкознания] (C Лазер-Паньків О. В. [Лазер-Панькив О. В.], panlazer@ukr.net

Особливості давньогрецьких фразеологізмів із компонентом-дендронімом [Особенности древнегреческих фразеологизмов с компонентом-дендронимом] (Українською / На укр. яз) 
в основу которых положено метафтонимию - сложный когнитивный механизм сочетания метафорь и метонимии (тип "метонимия внутри метафоры " значительно более продуктивный, чем тип "метафора внутри метонимии»). Наименее многочисленными являются ФЕ, основой создания которых является метонимия. Анализ семантики древнегреческих ФЕ с компонентом-дендронимом позволил выделить следующие виды мотивационной основы ФЕ: физические свойства деревьев, их частей и плодов, в том числе связанные с опытом их практического использования; практика использования деревьев, их частей $и$ плодов в различных ритуалах, обрядах и обычаях; историческое событие, в котором было задействовано определенное дерево или его часть; характеристики частей деревьев и плодов, связанные с их употреблением в пищу; упоминание о деревьях в мифах и преданиях.

Ключевые слова: древнегреческие фразеологизмы, дендроним, лингвокультурологический анализ, семантический анализ, внутренняя форма, метафора, метафтонимия, метонимия, мотивационная основа.

\title{
PECULIARITIES OF ANCIENT GREEK PROVERBS WITH DENDRONYM COMPONENT
}

\author{
Lazer-Pan'kivO.V., panlazer@ukr.net \\ PhD., Associative Professor \\ Taras Shevchenko National University of Kyiv, \\ Institute of Philology
}

The article represents the results of ancient Greek proverbs' with dendronym component peculiarities research (with tree species name, name of a part or a fruit of a tree and their derivates). On the basis of their linguocultural and semantic analysis the characteristics of their inner form were described. On this ground an assertion was made that dendronym FIG TREE has the greatest potential for proverb forming in ancient Greek language. The existence of different lexemes in ancient Greek language for certain types and parts of this tree designation attests the wide extent of this tree and its parts usage in everyday life of Hellenes. The proverbs containing dendronym OAK are also quite numerous, while dendronyms APPLE TREE, OLIVE TREE, MYRTLE TREE, LAUREL, MULBERRY TREE, PINE TREE, MASTIK TREE, THORN TREE, POMEGRANATE TREE, CORK TREE and PEAR TREE are used much less often. Such quantitative asymmetry is caused by the peculiarities of their everyday usage by Hellenes. The largest group consists of FU, in which the specific name of the tree (and not part of the tree or fruit) is used. The study of inner form of ancient Greek FU with the dendronym component allowed to determine the cognitive mechanisms of the secondary meaning formation. $62 \%$

Actual Problems of Linguistics [Aktual'ni problemy movoznavstva] (C) Lazer-Pan'kiv O. [Lazer-Pan'kivO.], panlazer@ukr.net

Peculiarities of Ancient Greek Proverbs with Dendronym Component [Osoblyvosti davn'ogrec'kyh frazeologizmiv iz komponentom-dendronimom] (in Ukrainian) 
FU are formed on the basis of metaphorization (on models "specific $\rightarrow$ abstract", "plant $\rightarrow$ human", "plant $\rightarrow$ object", "object $\rightarrow$ object"). An equally large group consists of proverbs with a dendronym component, based on metaftonimy, a complex cognitive mechanism of metaphor and metonymy combination (the type "metonymy within metaphor" is much more productive than the type "metaphor within metonymy"). The least numerous are FU formed on the basis of metonymy. The analysis of semantics of ancient Greek FU with the dendronym component made it possible to distinguish the following types of FU motivational basis: the physical characteristics of trees, their parts and fruits, associated with the experience of their practical usage; the practice of using trees, their parts and fruits in various rituals and customs; a historical event in which a certain tree or its part was involved; characteristics of tree parts and fruits concerning their consumption as food; the mention of trees in myths and legends.

Key words: ancient Greek phraseologisms, dendronym, linguoculturological analysis, semantic analysis, inner form, metaphor, metaphtonymy, metonymy, motivational basis.

Вступ. У руслі антропоцентричної парадигми сучасної лінгвістики особливо актуальними є дослідження фразеологічної системи мови, які, за Ж. В. Колоїз, “сприяють реконструюванню етнокогнітивних моделей національного мислення і знання, розв'язанню проблеми фонових знань комунікантів через виявлення паремійних аналогів й етнокультурних лакун, розкриттю найбільш важливих стереотипів масової свідомості й багатовікових векторів упливу на неї” [Колоїз 2014, 4]. “Саме фразеологічні фонди найкраще зберігають прототипні уявлення лінгвоспільнот” [Левченко 2007, 77]. Відтак, аналіз семантики ФО та когнітивних механізмів творення вторинного значення (дослідження концептуальної метафори та метонімії та опис конкретних механізмів вторинної номінації) є одним 3 пріоритетних та актуальних напрямків сучасної лінгвістики.

Рослинний світ, як зазначає Л. В. Пушко, “постає провідником між концептосферами ЛЮДИНА і ПРИРОДА” [Пушко 2007, 154]. Тому символічне значення рослин та особливості механізмів фразеотворення за їх участю у різних мовах $є$ об'єктом постійного інтересу дослідниківмовознавців. Так, аналізу символів (у тому числі, і рослинних) загалом та, зокрема, у складі фразеології присвячують свої праці Ю. Ковалюк [Ковалюк 2014], О. Левченко [Левченко 2005, 2007, 2008], Д. Лісничий [Лісничий 2007], М. Моторіна [Моторіна 2012], О. Моторний [Моторний 2011], 
Л. Пушко [Пушко 2007, 2008], Л. Савченко [Савченко 2013], Дж. Трессідер [Трессідер 1999], Л. Усик [Усик 2017], Г. Філь [Філь 2014, 2015] та інші. Когнітивні механізми творення вторинного смислу у ФО, зокрема, метафора, метонімія та метафтонімія, аналізуються на матеріалі різних мов у працях Л. Звонської [Звонська 2014], О. Шарманової [Шарманова 2011], D. Geeraerts [Geeraerts 2002], А. Сингаївської та О. Мосейчук [Сингаївська 2010] та інших. Незважаючи на достатньо велику кількість досліджень, не існує жодної праці, у якій би на матеріалі давньогрецької мови здійснювався комплексний аналіз семантичних особливостей фразеологізмів із компонентом - назвою рослин (зокрема, дендронімів).

Оскільки “пізнати, хоча б частково, концептосферу індивіда чи певного соціального угрупування можна завдяки вивченню семантики мовних знаків того чи іншого народу в певний історичний період його розвитку" [Попова 2013, 200], а фразеологія розуміється багатьма дослідниками як “відбиток картин реальності, у якій містяться фрагменти культури, історії, етнографії, психології, світогляду, релігії, менталітету, відтворюється національний характер народу, це своєрідний зразок ретельного та пильного кодування його духовної культури" [Савченко 2013, 522], дослідження семантики давньогрецьких ФО із компонентомденронімом, а також когнітивних механізмів творення у них вторинного значення викликає особливий інтерес дослідників у галузі класичної філології і набуває неабиякої актуальності.

Об'єктом дослідження стали давньогрецькі фразеологічні одиниці із компонентом-дендронімом. До компонентів-дендронімів зараховувалися видові назви дерев, назви плодів та частин деревних рослин (гілки, листя, насіння), а також їхні деривати.

Предмет дослідження - семантичні особливості, а також когнітивні механізми творення вторинного значення у давньогрецьких пареміях із компонентом-дендронімом.

Метою дослідження було проаналізувати семантичні особливості давньогрецьких паремій із компонентом-дендронімом, визначити і описати когнітивні механізми творення вторинного значення та дати характеристику мотиваційної основи творення зазначених ФО.

Матеріалом дослідження стали фразеологічні одиниці давньогрецької мови із компонентом-дендронімом (76 од.), відібрані 
методом суцільної вибірки з лексикографічних та пареміографічних джерел давньогрецької мови.

Виклад основного матеріалу. Для окреслення когнітивних механізмів творення вторинного значення необхідно, у першу чергу, звернутися до аналізу внутрішньої форми ФО, яка "є центром образа, що утворює мотиваційне підгрунтя ФО ... відіграє роль “посередника" між вторинними значеннями мовних одиниць і втіленим у знаках первинного найменування колективним досвідом народу” [Нагорна 2008, с. 5]. Отже, звернімося до лінгвокультурологічного та семантичного аналізу паремій із компонентом-дендронімом.

Серед проаналізованих ФО найбільшу групу становлять ФО 3 дендронімом смоква (26 од.). Про те, наскільки широко вживаним у побуті еллінів було це дерево та його плоди, свідчить наявність у давньогрецькій мові окремих лексем на позначення певних його різновидів та частин: $\dot{o}$

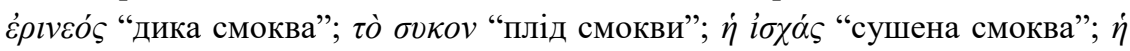

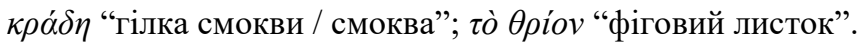

Метафоричне перенесення часто (7 од.) мотивоване фізичними характеристиками деревини смокви, яка була пориста та ні для чого не

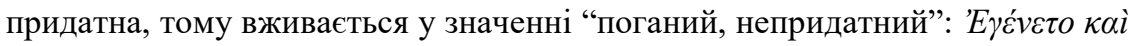

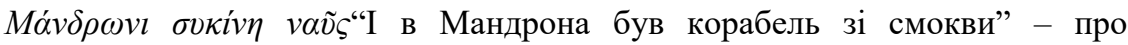

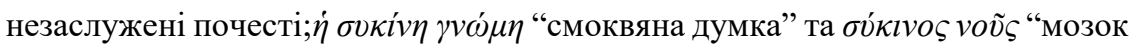

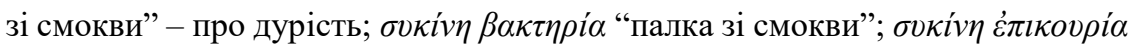

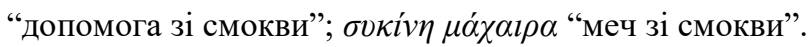

Традиційним для давніх еллінів було також використання свіжих та сушених плодів смокви у їжу в якості десерту. I, звичайно, була встановлена певна культура і порядок їхнього споживання, що відображено у вислові

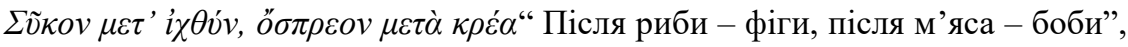
який вживається метафорично на позначення певного усталеного порядку, порушення якого не допускається у суспільстві.

Про те, що плоди смокви були традиційним вишуканим десертом у

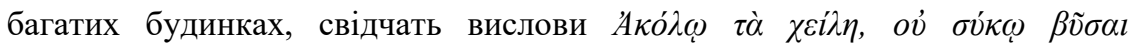
“Шматочком хліба, а не смоквою, наповнювати вуста" (заклик до простого життя) та $\Lambda \alpha \gamma \tilde{\omega} \pi \varepsilon \imath v \tilde{\omega} v \tau \iota ~ \kappa \alpha i ̀ ~ \pi \lambda \alpha \kappa о \tilde{v} \tau \tau \varepsilon \varsigma ~ \varepsilon i \varsigma ~ \sigma \tilde{v \kappa \alpha ~ " Г о л о д н о м у ~ з а и ̆ ц ю ~ і ~ х л і б ц і ~}$ за смокву".

У численних ФО відображено певні стереотипні уявлення, пов'язані 
iз вирощуванням, збиранням та споживанням смокви; 3 них ми можемо також дізнатися про певні обставини повсякденного життя стародавніх еллінів. Плоди смокви, з одного боку, були дешевими, відтак у пареміях вони метафорично вживаються на позначення чогось дешевого, нічого не вартого чи навіть непотрібного: $\dot{\alpha} v \tau$ ' $i \sigma \chi \alpha \dot{\delta} \delta \varsigma$ “за сушений інжир [смокву]”;

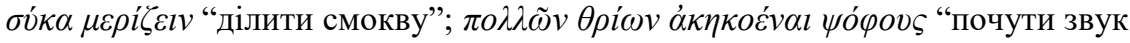

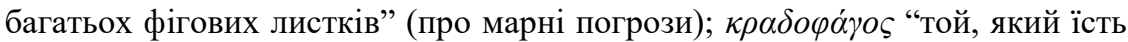
гілки смокви" (про бідних селюків).

Звернення до внутрішньої форми ФО часто допомагає зрозуміти

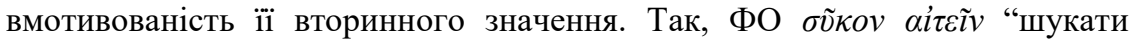
смокву” вживається у значенні “бути підлабузником", що зумовлене особливостями вирощування та продажу плодів смокви: афінські торговці лестили землеробам, бажаючи забрати в них найперші плоди смокви, які використовувалися для здійснення віщувань.

Відомим є факт, що у класичний період розвитку Стародавньої Греції у Афінах було заборонено рвати плоди священних смокв та вивозити їх, а щодо тих, хто повідомляв судову владу про порушників закону, вживали

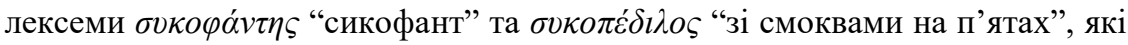

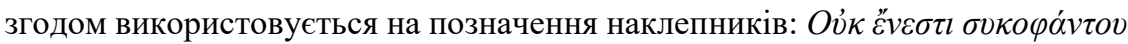
$\delta \dot{\gamma} \gamma \mu \alpha \tau o \varsigma<\varphi \alpha ́ \rho \mu \alpha \kappa o v>$ "Немає <ліків> від укусу сикофанта" .

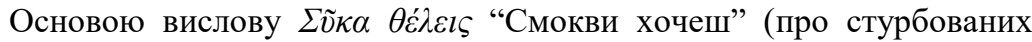
близькими небезпеками людей) стала відома історія про сицилійського купця, який, сидячи на березі після кораблетрощі, внаслідок якої втратив увесь вантаж смокви, сказав до моря: “Знаю, чого ти хочеш: смокви хочеш”.

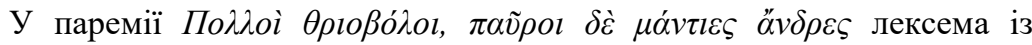
компонентом $\theta \rho \tilde{\imath} о \nu$ “листя смокви” згадується для створення паралелізму: "Багато викинутого листя смокви [та мало плодів, багато чоловіків], та мало віщунів" [Jones 1825, p. 593].

Традицію присвячувати плоди смокви Гермесу відображено у

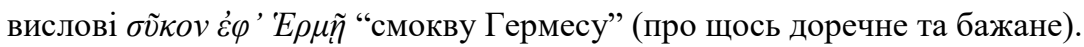

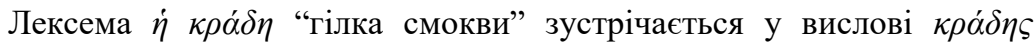
$\dot{\rho} \alpha \gamma \varepsilon i \sigma \eta \varsigma$ “коли зламана гілка смокви”. Він вживається на позначення чиєїсь раптової появи, адже актори, які з'являлися у трагічних сценах у ролі богів та допомагали розв'язати складні ситуації, прикрашали пояси гілками.

Зовнішня схожість плодів смокви між собою стала основою 


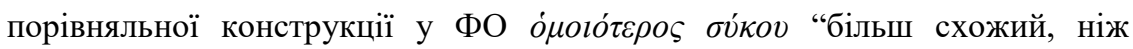
смоква”. Фізичні характеристики смокви імпліцитно присутні і у вислові

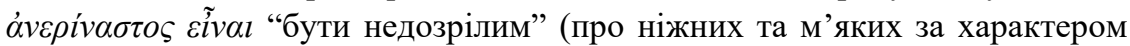
людей або ж тих, хто не доводить до кінця жодної справи, за аналогією до $\dot{\eta}$

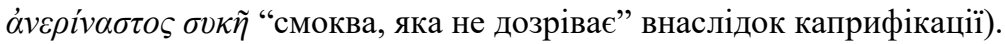

Досить чисельними (13 од.) $є$ також фразеологізми, у яких вживається дендронім дуб ( $\dot{\eta} \delta \rho \tilde{v} \varsigma)$. Як відомо, з дубом пов'язані численні давньогрецькі міфи, він використовувався у багатьох релігійних культах та обрядах.

Міфічна або релігійно-ритуальна основа присутня (експліцитно чи

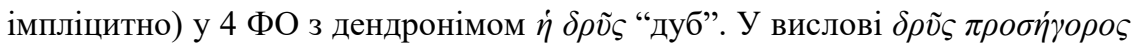

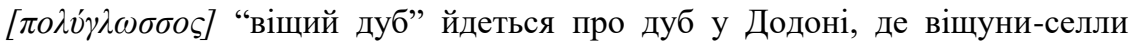
здійснювали пророцтва за шелестом листя та за звуком мідних посудин, по яких били дубовою гілкою. Основою творення ФО $\mu і \alpha \sigma \mu \alpha \delta \rho v o ́ \varsigma$ “ганьба дуба" стала історія зі жрицею, яку фіванці кинули в казан під час віщування в Додоні через ії кохання до одного з державних представників (теорів). Традиція споживання у їжу жолудів під час свята на честь Зевса символізує

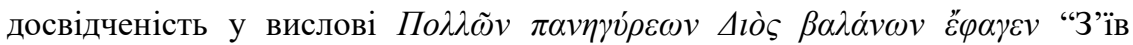
жолуді з багатьох свят Зевса".

Основою метафоричного використання дендроніма “дуб” у вислові

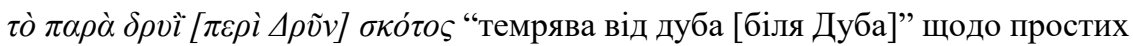
та лякливих людей стала історична подія у місті $\dot{\eta} \Delta \rho \tilde{v} \varsigma$ “Дуб”, де мілетці знищили мешканців Прієни; відтоді жінки Прієни присягаються темрявою дуба.

Однак у більшості ФО основою метафоричного використання лексеми $\dot{\eta} \delta \rho \tilde{v} \varsigma$ “дуб” стали, у першу чергу, ті характеристики, які були важливими для греків при використанні дуба у повсякденному житті. Відомо, що давні елліни, особливо найбідніші прошарки суспільства, досить тривалий час (ще до появи землеробства) вважали жолуді основною їжею [Вострецов 2017, 57]. Зміна культури харчування на краще (почали

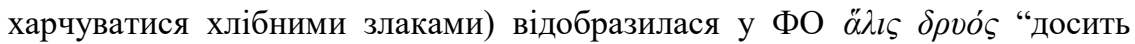
дуба”, що вживається загалом на позначення зміни життя на краще. Процес збирання жолудів зазнає метафоричного переосмислення у ФО $\ddot{\lambda} \lambda \lambda \eta v \delta \rho \tilde{v} v$ $\beta \alpha \lambda \alpha v i \zeta \varepsilon l v$ “збирати жолуді з іншого дуба" - звертання до тих, хто бере в борг в одного й того самого. 


\section{Фізичні характеристики дубової деревини стали основою} метафоричної транспозиції у висловах $\dot{\eta} \mu \alpha \lambda \alpha \kappa \grave{\eta} \delta \rho \tilde{v} \varsigma$ “трухлявий дуб” (про

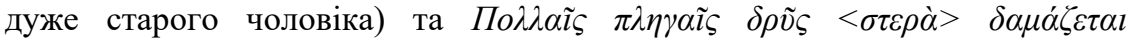
“<ТТвердий> Дуб зрубується численними ударами” (про щось міцне або неможливе).

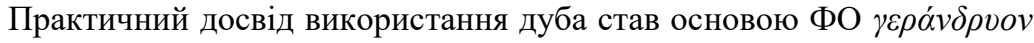
$\mu \varepsilon \tau \alpha \varphi v \tau \varepsilon v \varepsilon \varepsilon v$ “старий дуб пересаджувати” (про неможливу або марну

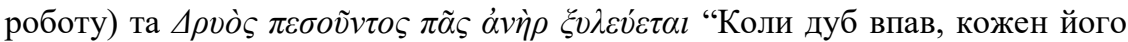
рубає" (про поведінку людей у суспільстві, коли хтось могутній зазнає невдачі чи поразки).

Певна опозиція між міфологічними уявленнями про дуб та його фізичними характеристиками, використовуваного у повсякденному житті,

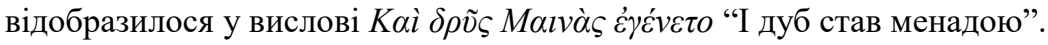

Серед проаналізованих ФО було виокремлено 6 висловів, у яких лексема $\dot{\eta} \delta \rho \tilde{v} \varsigma$ “дуб” та ії деривати вживаються у поєднанні з лексемою $\dot{\eta}$

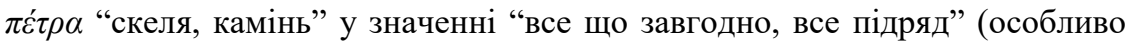
про порожні, беззмістовні балачки, вигадки та нісенітниці): $\ddot{\alpha} \lambda \iota \varsigma \delta \dot{\varepsilon} \delta \rho v o ́ \chi \omega v$

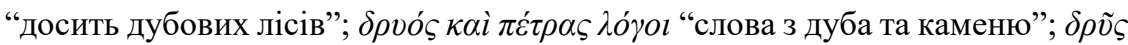

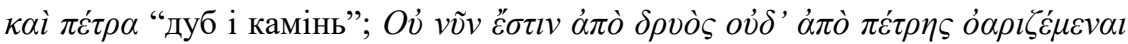

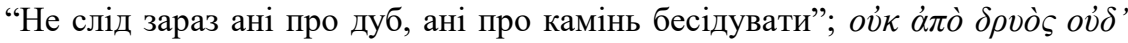

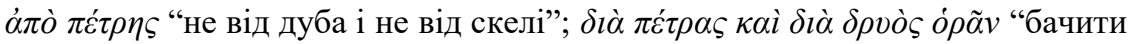
скрізь дуб і камінь".

Дендронім яблуня представлений у давньогрецькій фразеології

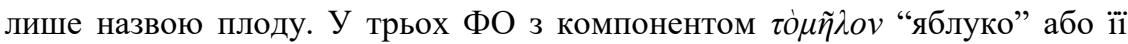
дериватом, внутрішня форма мотивована міфологічними уявленнями про

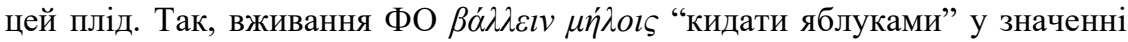
“добиватися коханої людини” стає зрозумілим лише після звернення до міфу про Аталанту, яка усім претендентам на іiі руку пропонувала позмагатися у бігу, і вбивала тих, кого наздоганяла. Лише Гіпомену вдалося iiï перехитрити за допомогою Афродити, якадала юнакові золоті яблука: він кидав яблука під час бігу, і Аталанта, піднімаючи їх, відстала.

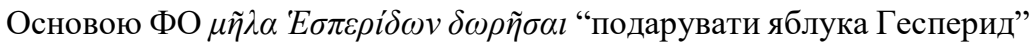
(“догоджати 3 дуже великими витратами”) став міф про чарівні золоті яблука, які оберігали геспериди. Міфологічну основу має також вислів $\tau \grave{o}$ $\tau \tilde{\eta} \varsigma$ ” $E \rho \imath \delta \varsigma \varsigma \tilde{\eta} \lambda o v$ “яблуко Ериди” (про причину сварки, предмет суперечки), 
пов'язаний із суперечкою олімпійських богинь через кинуте Еридою яблуко 3 написом "Найпрекраснішій”.

Тлумачення метафоричного значення прикметника $\mu \dot{\eta} \lambda \imath о \varsigma, 3$ у ФО

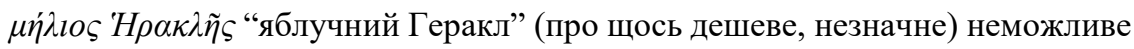
без лінгвокультурологічного коментування: в Афінах під час жертвоприношення Гераклу жертовний бик утік; тоді в яблуко встромили палички замість ніг і рогів так, щоб фігурка була схожа на бика, і завершили обряд жертвоприношення.

Серед ФО із компонентом-дендронімом було виокремлено 4 одиниці, у яких вживається дендронім олива. Основою метафоричного перенесення у них $\epsilon$ традиція використання олив та їх частин (гілок) під час спортивних

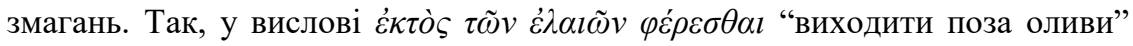
дендронім $\dot{\eta} \dot{\varepsilon} \lambda \alpha i \alpha$ “олива” вживається на позначення певних меж, адже стадії, на яких відбувалися змагання з бігу, були обмежені оливковими деревами відтак вислів набуває значення "виходити за дозволені межі; говорити чи робити щось недоречне".

Використання оливкових гілок чи оливкових вінків у якості винагороди під час спортивних змагань (що, за переказами, викликало неабиякий подив та захоплення представників інших етносів [ЛазерПаньків 2015, 271]) стало підставою для метафоричного використання

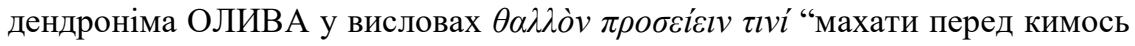
(оливковою) гілкою” (“спокушати”), ó оливу” (не заради слави чи перемоги, а за грошову або іншу винагороду),

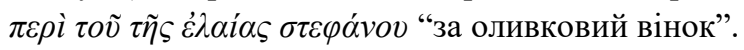

Символічне значення дендроніма мирт у давньогрецькій фразеологічній системі (4 од.) $є$ неоднозначним. Його метафоричне значення пов'язане виключно з використанням мирта у повсякденному житті. Так, про неосвічених людей, які не могли гідно та правильно

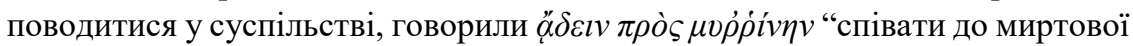
гілки”, адже той, хто не міг співати на бенкетах, брав гілку миртового дерева і співав до неї. Звичай вінчати голови правителів миртовими гілками відображено як у метафоричному використанні дієслова

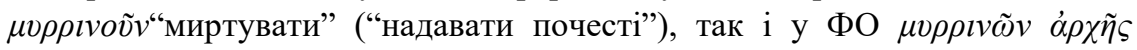
$\varepsilon \dot{\varepsilon} \iota \theta v \mu \varepsilon \tilde{v} v$ “бажати влади над миртом” (“прагнути почестей”).

Підступність змови, яку готували Гармодій і Аристогітон проти 


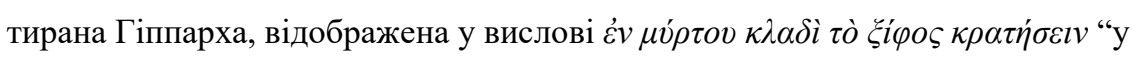
миртовій гілці меч тримати” (“готувати змову”), що має яскраву негативну конотацію.

Підступність та хитрість людини вербалізується також за допомогою

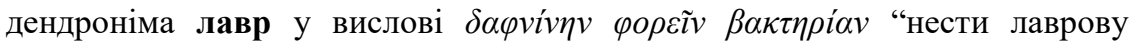
патерицю" (метафоричне вживання дендроніма ЛАВР базується на відомостях про лікувальні властивості лавра як протиотрути). Фізичні властивості лавра (звук, який він видає під час спалення) покладено в

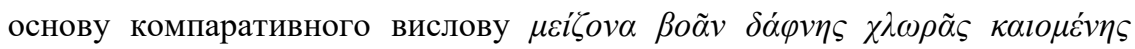
“сильніше кричати, аніж спалений зелений лавр”. Використання лавра під час обряду віщування лягло в основу метафоричної номінації пророків: $\tau \tilde{\omega} v$ $\dot{\alpha} \pi \grave{o} \delta \dot{\alpha} \varphi v \eta \varsigma$ “із тих, що з лавру”.

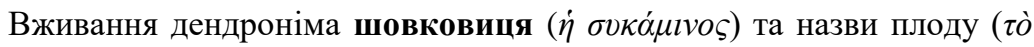
$\mu o ́ \rho o v)$ зумовлене метафоричним перенесенням фізичних властивостей шовковиці на поведінку людини у суспільстві ('H бvка́

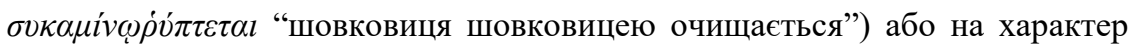

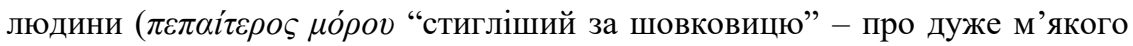
або легковірного чоловіка).

Сосна для давніх еллінів був символом смерті, загибелі. Це було зумовлене, зокрема, спостереженнями за особливостями іiі росту: зрубана сосна не відростає і не дає нових паростків, до того ж усі рослини, які ростуть поряд із сосною, гинуть. Відображенням цього є використання сосни під час релігійних ритуалів (зокрема, сосна служила знаком Кибели соснові дрова йшли на багаття для спалювання померлих, а корибанти (служителі Кібели) ходили 3 підвішеними на шиї сосновими шишками [Пилат 2006]). Таке символічне значення сосни відображене у ФО $\pi \varepsilon v ́ к \eta \varsigma$

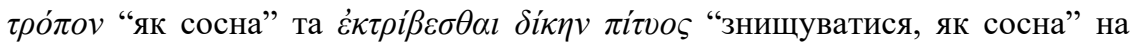
позначення повного знищення або смерті.

У корпусі проаналізованих ФО із компонентом-дендронімом було виявлено також один випадок використання лексеми $\dot{\eta} \kappa o \rho \delta \dot{\lambda} \lambda$ “шишка”:

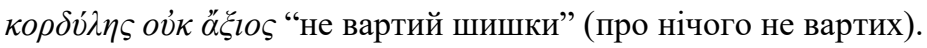

Серед рідковживаних у давньогрецькій фразеології дендронімів -

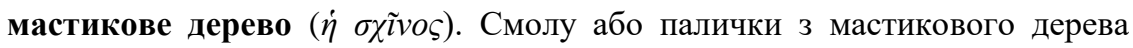
елліни жували після трапези з гігієнічною метою для підтримання чистоти зубів. Відтак, надмірна увага до власної зовнішності та одягу вербалізується 
через метафоричне використання лексеми $\dot{\eta}$ бұі̃vo “мастикове дерево / плід мастикового дерева" та іiі дериватів: $\sigma \chi \imath v о \tau \rho \tilde{\omega} \kappa \tau \alpha \iota$ (Ind.) “ті, хто жує смолу

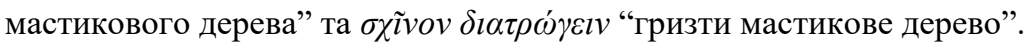

Фізичні характеристики терену (маленьке насіння та гострі колючки) стали основою метафоричної номінації у висловах $\pi \dot{\alpha} \pi \pi о \varsigma ~ \dot{\alpha} \kappa \alpha ́ v \theta \eta \varsigma$ "насінина терену” (про щось дуже мале, незначне) та ßís $\dot{\alpha} \kappa \alpha \nu \theta \dot{\delta} \delta \eta \varsigma$ “життя, поросле терном” (про важке, суворе та сповнене негараздів життя).

Плоди гранатового дерева мають у давньогрецькій культурі позитивне, міфологічне за походженням, символічне значення: вони були символом подружнього життя, плодючості, достатку та любові. Це

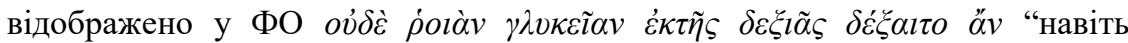
солодкого гранатового зерна не приймати з правиці” (від лихих людей не

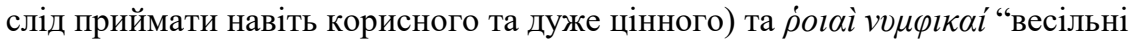
гранатові дерева" (про найкраще).

Серед висловів, у яких вживається назва частини певного виду дерев, слід згадати також ФО (2 од.) з лексемою $\delta \dot{o} \varphi \lambda \lambda \varsigma$ “кора коркового дерева”:

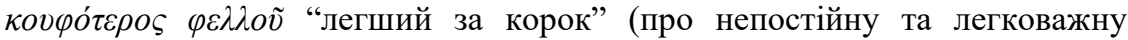
людину) та $\dot{\omega} \varsigma \varphi \varepsilon \lambda \lambda \dot{\varsigma} \varsigma$ “як корок” (про тих, хто може протистояти життєвим негараздам; за аналогією до коркової деревини, яка не тоне). Як видно, в основу метафоричної транспозиції в обох випадках покладено фізичні характеристики цієї кори.

Назва плоду груші зустрічається у єдиному вислові, де відбувається метафоричне перенесення фізичних характеристик стиглої груші на риси

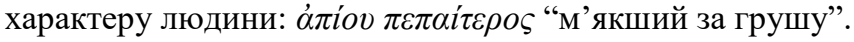

Отже, як показав аналіз семантичних особливостей давньогрецьких фразеологізмів із компонентом-дендронімом, найбільшу групу становлять паремії із компонентом - видовою назвою дерева (34 од.); серед них найбільший фразеотворчий потенціал має дендронім $\dot{\eta} \delta \rho \tilde{v} \varsigma$ “дуб” (та

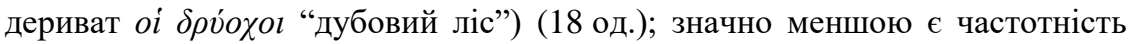
вживання видових назв інших дерев: три випадки вживання дендроніма $\dot{\eta}$

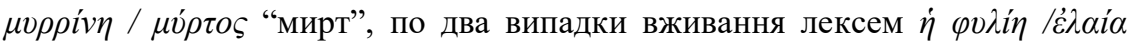

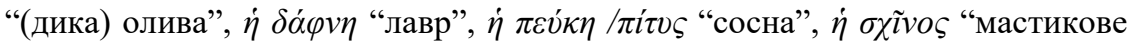
дерево”, $\dot{\eta} \not \alpha \kappa \alpha v \theta \alpha$ “терен” та по одному випадку вживання $\dot{\eta}$ бvко́ $\mu \nu v o \varsigma$

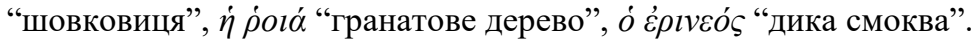

Меншою мірою вживані лексеми на позначення плодів дерев (25 од.). 
Серед них найбільше ФО із компонентом то̀ бг̃коv“плід смокви” (15 од.); вживаються також лексеми $\tau \grave{o} \mu \tilde{\eta} \lambda$ ov “яблуко" (4 од.), $\dot{\eta} \beta \dot{\alpha} \lambda \alpha v o \varsigma$ “жолудь”

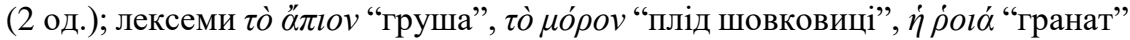
та $\dot{\eta} \kappa о \rho \delta \dot{\lambda} \lambda \eta$ “шишка" вживаються лише по одному разу.

Найменшу групу становлять ФО, у яких фразеотворення відбувається за участю лексеми на позначення частини дерева (17 од.). Серед них найбільш чисельними $є$ ФО із компонентом - назвою деревини

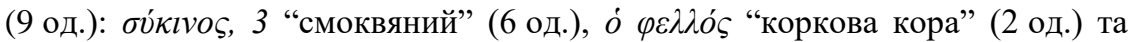
$\delta \alpha \dot{\varphi} \varphi v v o \varsigma, 3$ "зроблений 3 лавра" (1 од.); по 3 ФО із лексемами на позначеннягілок ( $\dot{\eta} \kappa \rho \alpha \dot{\delta} \eta$ “гілка смокви” та $\dot{o} \theta \alpha \lambda \lambda \dot{\varsigma} \varsigma$ “молода гілка”) та листя (

Здійснена характеристика внутрішньої форми давньогрецьких ФО із компонентом-дендронімом дозволяє окреслити когнітивні механізми творення зазначених ФО. Як стверджує С. Денисенко, “основою фразеологічного семіозису фразеологічної картини світу є метонімічне й метафоричне переосмислення" [Денисенко, с. 5]. Аналіз семантики давньогрецьких ФО із компонентом-дендронімом дозволяє виокремити групи ФО, в основу яких покладено метафору, метонімію та метафтонімію.

Метафора, як показують результати численних досліджень на матеріалі різних мов, є найбільш поширеним засобом творення вторинної номінації у фразеології. "Перенесення знака здійснюється за подібністю зорових, слухових, кольорових i подібних ознак, на основі найрізноманітніших вражень за внутрішнім зв'язком" [Звонська 2014, c. 160]. “Порівняння, а радше зіставлення двох об'єктів, є одним 3 етапів метафоротворення, який дає підгрунтя для подальших когнітивних операцій” [Левченко 2007, с. 49]. Саме за допомогою метафори мовець може позначити невідоме через добре відоме, абстрактне через конкретне тощо. Серед давньогрецьких ФО із компонентом-дендронімом $62 \%$ створені на основі метафоризації. 3 усіх моделей метафоричного перенесення, які виокремлюються лінгвістами (див., зокрема, [Сингаївська 2010]), у давньогрецьких пареміях із компонентом-дендронімом використовуються наступні:

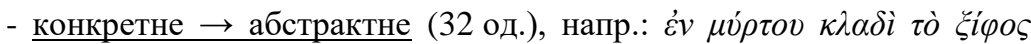
$\kappa \rho \alpha \eta \dot{\sigma \varepsilon \varepsilon v ~ “ у ~ м и р т о в і и ̆ ~ г і л ц і ~ м е ч ~ т р и м а т и ” ~(г о т у в а т и ~ з м о в у) ; ~ \beta i o \varsigma ~ \alpha ́ \kappa \alpha \nu ~} \theta \dot{\omega} \delta \eta \varsigma$

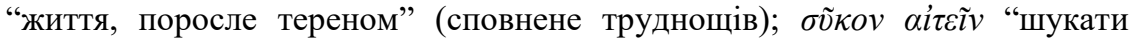


смокву" (лестити, бути підлабузником) та ін.;

- рослина $\rightarrow$ людина (тут і далі під рослиною мається на увазі видова назва дерева, назва частини чи плоду дерева) (8 од.), напр.: $\dot{\eta} \mu \alpha \lambda \alpha \kappa \grave{\eta} \delta \rho \tilde{v} \varsigma$

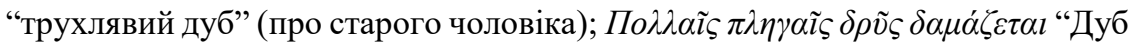
зрубується численними ударами” та ін.

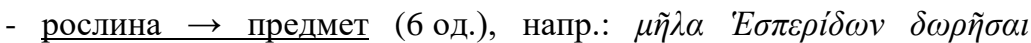

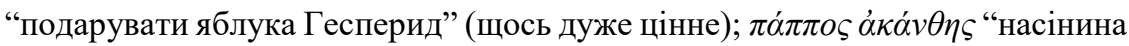
терену” (щось дешеве, незначне) та ін.

- предмет $\rightarrow$ предмет (1 од.): $\mu \eta \dot{\lambda} \iota о \varsigma ~ Н \rho \alpha \kappa \lambda \tilde{\eta} \varsigma$ “яблучний Геракл” (про щось незначне).

Не менш чисельну групу становлять фразеологізми 3 компонентомдендронімом, в основу яких покладено складний когнітивний механізм поєднання метафори та метонімії, названий Л. Гусенсом метафтонімія (17 од.). Серед них було виокремлено наступні групи ФО за типом метафтонімії (за класифікацією Л. Гусенса [Шарманова 2011, с. 195-196]):

1) тип метонімія всередині метафори (14 од.). Метафорична номінація у 13 з них відбувається за моделлю “конкретне $\rightarrow$ абстрактне”, i лише в одному вислові - за моделлю “предмет $\rightarrow$ людина". Спільною ознакою усіх ФО цієї групи є те, що в основі метафоричної номінації у них покладено метонімічне перенесення, зокрема, за моделями: позначення об'єкта дії замість дії (7 од.), суб'єкта дії замість дії (3 од.), дії замість суб'єкта (1 од.), місця дії замість дії (1 од.), цілого замість частини (1 од.), частини замість цілого (1 од.). Наприклад, в основі метафоричної номінації

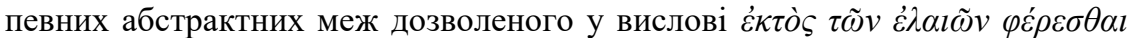
“виходити поза оливи” лежить метонімічне вживання дендроніма $\dot{\eta} \dot{\varepsilon} \lambda \alpha i \alpha$ “олива" на позначення обмеження місця змагання; метафоричне вживання

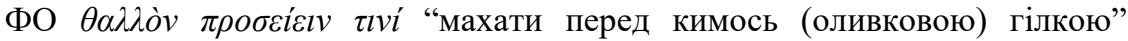
(конкретна дія) у абстрактному значенні “спокушати” базується на метонімічному вживанні дендроніма $\delta \quad \theta \alpha \lambda \lambda o ́ \varsigma$ (знаряддя дії) на позначення самої дії (нагородження переможців оливковими гілками або вінками з цих гілок).

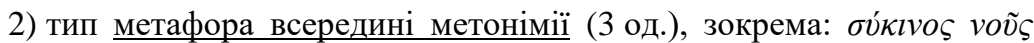
“мозок зі смокви”; $\dot{\eta}$ бvкív $\gamma v \omega ́ \mu \eta$ “фігова [смоквяна] думка" (в обох висловах в основі метонімічного позначення розумових здібностей людини шляхом вказівки на іï розум / думку лежить метафоричне використання 
прикметника бv́кıvos, 3 “смоквяний” у значенні “поганий”).

Найменш чисельними (2 од.) є ФО із компонентом-дендронімом, основою творення яких $є$ метонімія, при якій відбувається перенесення “знака за суміжністю певних двох предметів (явищ), зокрема тих, що перебувають між собою у часовому і просторовому зв'язку, у причиннонаслідкових відношеннях, у різного роду зіставленнях за дотичністю" [Звонська 2014, с. 162], при цьому “одна сутність (джерело) забезпечує ментальний доступ до іншої концептуальної сутності (мети) у межах тієї

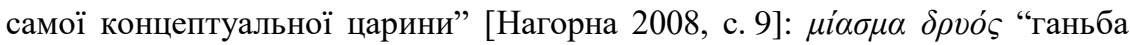
дуба", у якому метонімічне перенесення відбувається за схемою “місце (де здійснили злочин) $\rightarrow$ атрибут місця (дерево, яке у цьому місці росте)”, та $\Sigma \tilde{v} \kappa \alpha \theta \dot{\varepsilon} \lambda \varepsilon l \varsigma$ "Смокви хочеш”, у якому використано модель метонімізації “дія $\rightarrow$ стан (емоційна реакція на цю дію)”.

Зважаючи на те, що “фразеологізми вербалізують інформацію особливо значущу для лінгвоспільноти” [Левченко 2007, с. 77], у процесі творення вторинного значення у ФО 3 компонентом-дендронімом мотиваційною основою виступали різні характеристики дерев, їхніх частин та плодів. Це пов'язано з тривалим досвідом використання дерев у різних галузях життя людини. "Рослинні слова-символи, - зазначає М. С. Моторіна, - $є$ одними 3 найпоширеніших серед усього шару етносимволів мовної картини світу" [Моторіна 2012, с. 173] (дерево, наприклад, - “багатозначний прадавній символ, відомий практично всім народам світу” [Пилат 2006]). Отже, “практичне застосування рослин та обізнаність із їх властивостями, так чи так, ставали джерелом найменувань” [Усик 2017, с. 21]. Зокрема, аналіз семантики давньогрецьких ФО із компонентом-дендронімом дозволив виокремити наступні види мотиваційної основи ФО:

- фізичні властивості дерев, їхніх частин та плодів, в тому числі

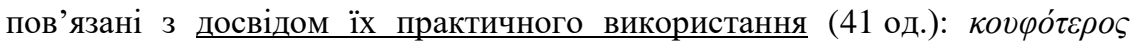

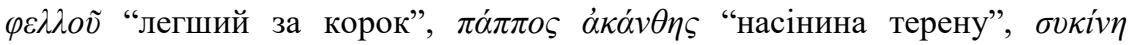

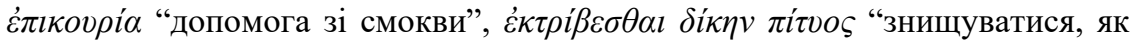

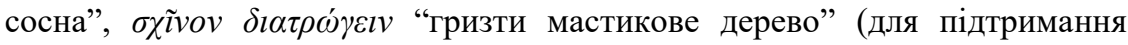

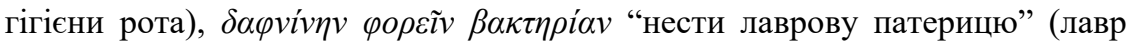
використовувався як протиотрута) та інші;

- практика використання дерев, їхніх частин та плодів у 


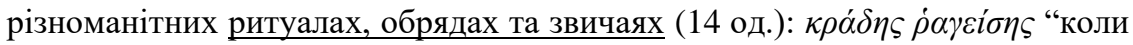
зламана гілка смокви" (використовувалися у трагедіях), $\mu \nu \rho \rho \nu \tilde{\omega} v \dot{\alpha} \rho \chi \tilde{\eta} \varsigma$

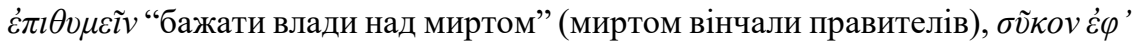
Е $\rho \tilde{\eta}$ “смокву Гермесу” (смокву посвячували Гермесу під час релігійних обрядів) та інші;

- історична подія, у якій було задіяне певне дерево чи його частина (8

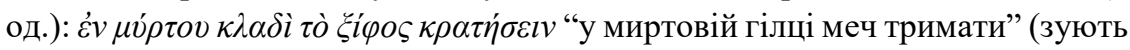
зі змовою, організованою Гармодієм і Аристогітоном проти тирана Гіппарха) та інші;

- характеристики частин дерев та плодів, пов'язані 3 вживанням їх у

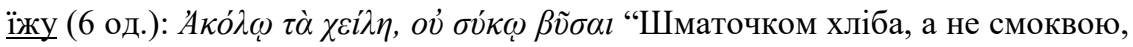
наповнювати вуста" та інші;

- згадка про дерева у міфах та переказах (4 од.): $\tau \grave{o} \tau \tilde{\eta} \varsigma ~ " E \rho \imath \delta o \varsigma ~ \mu \tilde{\eta} \lambda o v$

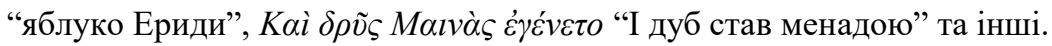

Висновки і перспективи подальших досліджень. Отже, аналіз давньогрецьких паремій із компонентом-дендронімом дає підстави зробити наступні висновки. Найбільший фразеотворчій потенціал у давньогрецькій мові мають дендроніми СМОКВА, ДУБ, МИРТ та ОЛИВА, що зумовлене особливостями їх практичного застосування давніми еллінами у повсякденному житті. Причому найбільшу групу становлять ФО, у яких вживається саме видова назва дерева (а не частини дерева чи плоду).

Серед когнітивних механізмів розвитку вторинного значення давньогрецьких ФО найбільш продуктивною $є$ метафора (зокрема, за моделлю “конкретне $\rightarrow$ абстрактне”, яка використовується у 42 \% усіх проаналізованих ФО), хоча досить численними $\epsilon$ також випадки використання метафтонімії (22\%). Найменш регулярними є метонімічні моделі (лише 2 од.).

Мотиваційна основа ФО із компонентом-дендронімом досить розмаїта. На основі аналізу семантики зазначених ФО можна зробити висновок, що для давніх еллінів визначальними при творенні вторинного значення були фізичні властивості дерев, їхніх частин та плодів, у тому числі пов’язані із досвідом їхнього практичного використання (54 \%), у той час як певні міфологічні уявлення про рослини досить рідко ставали мотивуючим фактором використання дендронімів у ФО (лише 0,05 \% випадків).

Звичайно, проведений аналіз не вирішує усіх питань, пов’язаних із

Актуальні проблеми мовознавства [Актуальные проблемы языкознания] (C)Лазер-Паньків О. В. [Лазер-Панькив О. В.], panlazer@ukr.net Особливості давньогрецьких фразеологізмів із компонентом-дендронімом [Особенности древнегреческих фразеологизмов с компонентом-дендронимом] (Українською / На укр. яз) 
особливостями давньогрецької фразеологічної картини світу. Подальше дослідження лінгвокультурологічних, структурних та семантикокогнітивних особливостей давньогрецьких паремій дозволить виявити певні етноспецифічні риси давньогрецької фразеологічної системи, а також встановити релевантні для давньогрецької лінгвокультури образні уявлення про світ.

\section{Література:}

1. Вострецов, Ю. Е. «О забытом желуде.» Исторические, философские, политические и юридические науки, культурология и искусствоведение. Вопросы теории и практики8 (82) (Тамбов, Грамота, 2017): 57-59.

2. Денисенко, С.Н. Відображення фразеологічної картини світу в семантиці фразеологізмів, доступ http://www.stattionline.org.ua/filologiya/31/1874-vidobrazhennyafrazeologichno\%D1\%97-kartini-svitu-v-semantici-frazeologizmiv.html

3. Звонська, Л. Л. «Метафоричне фразеотворення у Новому Завіті.» Міжнародний вісник. Культурологія. Філологія. Музикознавство ІІ (3)(2014): 159-165.

4. Ковалюк, Ю. В. «Фразеологізми 3 компонентом vegetable в національних картинах світу.» Вісник Житомирського державного університету імені Івана Франка 2 (2014): 117 120.

5. Колоїз Ж. В., Шарманова Н. М. Українська пареміологія: Практикум, за ред. Ж. В. Колоїз (Кривий Ріг, 2014), 77.

6. Левченко, О. П. «Фразеологічна символіка: лінгвокультурологічний аспект: монографія.» (Львів, ЛРІДУ НАДУ, 2005), 263.

7. Левченко, О. П. «Символи у фразеологічних системах української та російської мов: лінгвокультурологічний аспект.»(Дис. д-ра філол. наук, Львів, 2007), 720.

8. Левченко, О. «Рослинна символіка у фразеологічних системах (лінгвокультурологічний аспект).» Од слова путь верстаючи й до слова ... (2008): 552-566.

9. Лісничий, Д. В. «Дендроніми у поетичних текстах першої половини ХХ століття (семантичний і функціональний аспекти).» Автореф. дис. канд. філол. наук, Київ, 2007.

10. Моторіна, М. С. «Етносимволи у складі українських фразеологізмів з компонентаминазвами рослин: семантичний аспект.» Культура народов Причерноморья 248(2012): 173-175.

11. Моторний, О. А. «Компонент-назва рослини як складова фразеології верхньолужицької мови.» Мова і культура14, т. 5(2011): 128-133.

12. Нагорна, О. О. «Етнокультурні особливості семантики англійських фразеологізмів (на матеріалі британського варіанту англійської мови).» Автореф. дис. канд. філол. наук, Одеса, 2008.

13. Пилат, О. С. «Символ дерева в міфології народів світу.» Науковий вісник НЛТУ України16.4(2006), доступhttp://nltu.edu.ua/nv/Archive/2006/16_4/124_Pylat_16_4.pdf

14. Попова, Н. М. «Моделювання національної концептосфери: семантичний аналіз та когнітивна інтерпретація.» Проблеми семантики слова, речення та тексту 31(2013): 197-207.

15. Пушко, Л. В. «Антропометричність фразеологізмів з фітоморфними номінаціями (на

Actual Problems of Linguistics [Aktual'ni problemy movoznavstva]

(C)Lazer-Pan'kivO. [Lazer-Pan'kivO.], panlazer@ukr.net

Peculiarities of Ancient Greek Proverbs with Dendronym Component [Osoblyvosti davn'ogrec'kyh frazeologizmiv iz komponentom-dendronimom] (in Ukrainian) 
матеріалі англійської і української мов).» Вісник СумДУ, Серія: Філологія 2(2007): 154-157.

16. Пушко Л. В. «Реалізація аксіологічної функції фразеологізмів 3 рослинними номінаціями на позначення інтелектуальної діяльності людини (на матеріалі англійської, української та російської мов).» Вісник СумДУ, Серія: Філологія 1(2008): 87-89.

17. Савченко, Л. В. Феномен етнокодів духовної культури у фразеології української мови: етимологічний та етнолінгвістичний аспекти: монографія (Сімферополь, Доля, 2013), 600.

18. Сингаївська А. В., Мосейчук О. М. «Когнітивні механізми формування семантики однослівних ідіом.» Вісник Житомирського державного університету імені Івана Франка 51 (2010): 69-73.

19. Усик, Л. М. «Когнітивно-ономасіологічна реконструкція оцінного компонента у семантиці фітонімів (на матеріалі назв лікарських рослин у німецькій, англійській, російській та українській мовах).»(Дис. канд. філол. наук, Київ, 2017), 254.

20. Філь, Г. «Компоненти-дендроніми в структурі фразеологічних одиниць української мови як етнокультурні маркери мовної картини світу.» Рідне слово в етнокультурному вимірі(2014): 86-92.

21. Філь, Г.«Фразеологічні одиниці української мови 3 рослинними компонентамисимволами: етнонаціональний аспект.» Проблеми гуманітарних наук, Серія: Філологія 36(2015): 116-126.

22. Шарманова, О. С. «Метафтонимия как концептуальное взаимодействие метафоры и метонимии.» Вестник ИГЛУ(2011): 194-200, доступ https://cyberleninka.ru/article/n/ metaftonimiya-kak-kontseptualnoe-vzaimodeystvie-metafory-i-metonimii

23. Geeraerts, D. «The Interaction of Metaphor and Metonymy in Composite Expressions.» Metaphor and Metonymy in Comparison and Contrast, red. René Dirven \& Ralf Pörings (Berlin, Mouton de Gruyter, 2002): 435-465, доступ http://wwwling.arts.kuleuven.be/qlvl/PDFPublications/ 02Theinteraction.pdf

\section{Джерела ілюстративного матеріалу:}

24. Вейсман, А. Д. Греческо-русский словарь(Москва, Греко-латинский кабинет Ю. А. Шичалина, 1991), 1370.

25. Дворецкий, И. Х. Древнегреческо-русский словарь:в 2 т. (Москва, Гос. изд-во иностранных и национальных словарей, 1958), 1904.

26. Лазер-Паньків, О.ПАРОІМІАI ЕААНNIKAI: Давньогрецькі прислів'я та приказки: словник-довідник (Київ, ВПЦ “Київський університет”, 2015), 447.

27. Михельсон, М. И. Русская мысль и речь. Свое и чужое. Опыт русской фразеологии: Сборник образных слов и иносказаний,т. 1-2 (Санкт-Петербург, Тип. АН, 1896-1912), 2208.

28. Тресиддер, Дж. Словарь символов, пер. с англ. С. Палько (Москва, Гранд: ФАИРПресc, 1999), 443.

29. Bestiaria Latina, доступ http://schoolhousewidgets.blogspot.com/2011/12/greekproverbs-reference-page.html.

30. Corpus paroemiographorum graecorum, t. I-II,ed. E. L. a Leutsch, F. G. Schneidewin (Gottingae, 1839-1851).

Актуальні проблеми мовознавства [Актуальные проблемы языкознания]

(C)Лазер-Паньків О. В. [Лазер-ПанькивО.В.], panlazer@ukr.net

Особливості давньогрецьких фразеологізмів із компонентом-дендронімом [Особенности древнегреческих фразеологизмов с компонентом-дендронимом] (Українською / На укр. яз) 
31. Index adagiorum Graecorum, доступ http://jvpoll.home.xs4all.nl/back/Web/ erasmusa.htm

32. Jones, J.The Tyro's Greek and English Lexicon: Or a Compendium in English of the Lexicons of Damm, Sturze, Schleusner, Schweighaeuser (London, Longman, Hurst, Rees, Orme, Brown, and Green, 1825), 1482.

33. Liste griechischer Phrasen, доступ http://de.wikipedia.org/wiki/ Liste_griechischer_Phrasen.

\section{References}

1. Vostretsov, Yu. E. «O zabyitom zhelude [About the forgotten acorn].» Istoricheskie, filosofskie, politicheskie i yuridicheskie nauki, kulturologiya i iskusstvovedenie. Voprosy teorii i praktiki8 (82) (Tambov, Gramota, 2017): 57-59 (In Russ.).

2. Denysenko, S. N., Vidobrazhennya frazeolohichnoyi kartyny svitu $v$ semantytsi frazeolohizmiv [Electronic resource, Reflection of the phraseological picture of the world in the semantics of phraseologisms], access mode http://www.stattionline.org.ua/filologiya/31/1874vidobrazhennya-frazeologichno\%D1\%97-kartini-svitu-v-semantici-frazeologizmiv.html (In Ukr.).

3. Zvons'ka, L. L. «Metaforychne frazeotvorennya u Novomu Zaviti [Metaphorical phrases-forming in the New Testament].» Mizhnarodnyy visnyk. Kul'turolohiya. Filolohiya. Muzykoznavstvo II (3) (2014): 159-165 (In Ukr.).

4. Kovalyuk, Yu. V.«Frazeolohizmy z komponentom vegetable $\mathrm{v}$ natsional'nykh kartynakh svitu [Phraseologisms with vegetable component in national pictures of the world].» Visnyk Zhytomyrs 'koho derzhavnoho universytetu imeni Ivana Franka 2 (2014): 117-120 (In Ukr.).

5. Koloyiz Zh. V., Sharmanova N. M. Ukrayins'ka paremiolohiya : Praktykum [Ukrainian Paremyology: Workshop],za red. Zh. V. Koloyiz (Kryvyy Rih, 2014),77 (In Ukr.).

6. Levchenko, O. P. Frazeolohichna symvolika: linhvokul'turolohichnyy aspect [Phraseological symbolism: linguistic and cultural aspect] (L'viv, LRIDU NADU, 2005), 263 (In Ukr.).

7. Levchenko, O. P. «Symvoly u frazeolohichnykh systemakh ukrayins'koyi ta rosiys'koyi mov: linhvokul'turolohichnyy aspekt [Symbols of Ukrainian and Russian phraseological Systems: the Linguacultural Aspect].» (Dys. d-ra filol. nauk, L’viv, 2007), 720 (In Ukr.).

8. Levchenko, O. «Roslynna symvolika u frazeolohichnykh systemakh (linhvokul'turolohichnyy aspekt) [Plant symbolism in phraseological systems (linguocultural aspect)].» Od slova put' verstayuchy y do slova ...(2008): 552-566 (In Ukr.).

9. Lisnychyy, D. V. «Dendronimy u poetychnykh tekstakh pershoyi polovyny XX stolittya (semantychnyy i funktsional'nyy aspekty) [Dendronyms in poetical texts of the first part of the 20th century (semantic and functional aspects)].» Avtoref. dys. kand. filol. nauk, Kyyiv, 2007 (In Ukr.).

10. Motorina, M. S. «Etnosymvoly u skladi ukrayins'kykh frazeolohizmiv z 
komponentamy-nazvamy roslyn: semantychnyy aspekt [Ethnic Symbols in Ukrainian Phraseologisms with Plant Names Components: Semantic Aspect].»Kul'tura narodov Prychernomor'ya 248 (2012): 173-175 (In Ukr.).

11. Motornyy, O. A. «Komponent-nazva roslyny yak skladova frazeolohiyi verkhn'oluzhyts'koyi movy [Name of the plant as a component of the phraseology of the UpperLusan language].» Mova i kul'tura 14, t. 5 (2011): 128-133.

12. Nahorna, O. O. «Etnokul'turni osoblyvosti semantyky anhliys'kykh frazeolohizmiv (na materiali brytans'koho variantu anhliys'koyi movy) [Ethnocultural Features of English Phraseological Units' Semantics (A Study of British English)].» Avtoref. dys. kand. filol. nauk, Odesa, 2008 (In Ukr.).

13. Pylat, O. S. «Symvol dereva v mifolohiyi narodiv svitu [Electronic resource, The symbol of the tree in the mythology of the peoples of the world].» Naukovyy visnyk NLTU Ukrayiny 16.4 (2006), access mode http://nltu.edu.ua/nv/Archive/2006/16_4/ 124_Pylat_16_4.pdf (In Ukr.).

14. Popova, N. M. «Modelyuvannya natsional'noyi kontseptosfery: semantychnyy analiz ta kohnityvna interpretatsiya [Modeling of the national conceptual sphere: semantic analysis and cognitive interpretation].» Problemy semantyky slova, rechennya ta tekstu 31 (2013): 197-207 (In Ukr.).

15. Pushko, L. V. «Antropometrychnist' frazeolohizmiv z fitomorfnymy nominatsiyamy (na materiali anhliys'koyi i ukrayins'koyi mov) [Anthropometricity of phraseologisms with phytomorphic nominations (on the material of English and Ukrainian languages)].» Visnyk SumDU, Seriya Filolohiya 2 (2007): 154-157 (In Ukr.).

16. Pushko, L. V. «Realizatsiya aksiolohichnoyi funktsiyi frazeolohizmiv $\mathrm{z}$ roslynnymy nominatsiyamy na poznachennya intelektual'noyi diyal'nosti lyudyny (na materiali anhliys'koyi, ukrayins'koyi ta rosiys'koyi mov) [Implementation of the axiological function of phraseologisms with vegetable nominations on the designation of human intellectual activity (on the material of English, Ukrainian and Russian languages)].»Visnyk SumDU, Seriya Filolohiya1 (2008): 87-89 (In Ukr.).

17. Savchenko, L. V. Fenomen etnokodiv dukhovnoyi kul'tury u frazeolohiyi ukrayins'koyi movy: etymolohichnyy ta etnolinhvistychnyy aspekty [The phenomenon of ethnocods of spiritual culture in the phraseology of the Ukrainian language: etymological and ethnolinguistic aspects] (Simferopol', Dolya, 2013), 600 (In Ukr.).

18. Synhayivs'ka A. V., Moseychuk O. M. «Kohnityvni mekhanizmy formuvannya semantyky odnoslivnykh idiom [Cognitive mechanisms for the formation of one-word idioms semantics].» Visnyk Zhytomyrs 'koho derzhavnoho universytetu imeni Ivana Franka 51(2010): 69-73 (In Ukr.).

19. Usyk, L. M. «Kohnityvno-onomasiolohichna rekonstruktsiya otsinnoho komponenta u semantytsi fitonimiv (na materiali nazv likars'kykh roslyn u nimets'kiy, anhliys'kiy, rosiys'kiy ta ukrayins'kiy movakh) [Cognitive onomasiological reconstruction of evaluative component in the semantics of phytonyms (in medicinal plant names in the German, English, Russian and Ukrainian languages)].» (Dys. kand. filol. nauk, Kyyiv, 2017), 254 (In Ukr.). 
20. Fil', H. «Komponenty-dendronimy v strukturi frazeolohichnykh odynyts' ukrayins'koyi movy yak etnokul'turni markery movnoyi kartyny svitu[Componentsdendronyms in the structure of the phraseological units of the Ukrainian language as ethnocultural markers of the linguistic picture of the world].» Ridne slovo $v$ etnokul'turnomu vymiri(2014): 86-92 (In Ukr.).

21. Fil’, H. «Frazeolohichni odynytsi ukrayins'koyi movy z roslynnymy komponentamy-symvolamy: etnonatsional'nyy aspekt[Phraseological units of the Ukrainian language with plant components symbols: ethno-national aspect].» Problemy humanitarnykh nauk. Seriya Filolohiya 36 (2015): 116-126(In Ukr.).

22. Sharmanova, O. S. «Metaftonimiya kak kontseptual'noe vzaimodeystviye metafory i metonimii[Electronic resource, Metaphtony as a conceptual interaction of metaphors and metonymy].» Vestnik IHLU(2011): 194-200, access mode https://cyberleninka.ru/article/ n/metaftonimiya-kak-kontseptualnoe-vzaimodeystvie-metafory-i-metonimii(In Russ.).

23. Geeraerts, D. «The Interaction of Metaphor and Metonymy in Composite Expressions [Electronic resource].» Metaphor and Metonymy in Comparison and Contrast, red. René Dirven \& Ralf Pörings (Berlin, Mouton de Gruyter, 2002): 435-465, access mode http://wwwling.arts.kuleuven.be/qlvl/PDFPublications/02Theinteraction.pdf

24. Veysman, A. D. Hrechesko-russkiy slovar'[Greek-Russian dictionary] (Moskva, Hreko-latinskiy kabinet Yu. A. Shychalina, 1991),1370 (In Russ.).

25. Dvoreckij, I. H. Drevnegrechesko-russkij slovar' [Ancient Greek-Russian vocabulary],v. 1-2(Moskva, Gosudarstvennoe izdatel'stvo inostrannyh i nacional'nyh slovarej, 1958), 1904 (In Russ).

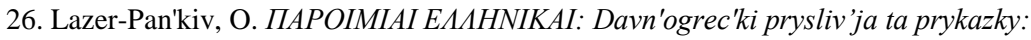
slovnyk-dovidnyk [ПAPOIMIAI EAAHNIKAI: Ancient Greek proverbs and sayings](Kyyiv, VPC “Kyi'vs'kyj universytet”, 2015), 447 (In Ukr.).

27. Mihel'son, M. I. Russkaja mysl' i rech'. Svoe i chuzhoe. Opyt russkoj frazeologii: Sbornik obraznyh slov i inoskazanij [Russian thought and speech], v. 1-2 (St. Petersburg, Tip. AN, 1896-1912), 2208 (In Russ).

28. Tresydder, Dzh. Slovar' symvolov [Dictionary of Symbols] (Moskva, Hrand, FAYR-Press, 1999), 443 (In Russ.).

29. Bestiaria Latina, access mode: http://schoolhousewidgets.blogspot.com/2011/12/ greek-proverbs-reference-page.html.

30. Corpus paroemiographorum graecorum, t. I-II, ed. E. L. a Leutsch, F. G. Schneidewin (Gottingae, 1839-1851).

31. Index adagiorum Graecorum, access mode http://jvpoll.home.xs4all.nl/back/Web/ erasmusa.htm

32. Jones, J. The Tyro's Greek and English Lexicon: Or a Compendium in English of the Lexicons of Damm, Sturze, Schleusner, Schweighaeuser (London, Longman, Hurst, Rees, Orme, Brown, and Green, 1825), 1482.

33. Liste griechischer Phrasen, access mode http://de.wikipedia.org/wiki/ Liste_griechischer_Phrasen. 
УДК 811.14:81’373

Стаття надійшла до редакиії 10.07.2018 Перевірено на плагіат 15.07.2018 p. унікальність $-97.46 \%$

\section{ВЕРБАЛІЗАЦІЯ МІЗОГІНІСТИЧНИХ УЯВЛЕНЬ У ДАВНЬОГРЕЦЬКИХ ПАРЕМІЯХ}

Левко Олександр Вадимович, o.levko@knu.иа, канд. філол. наук, доц.

Київський національний університет імені Тараса Шевченка, Інститут філологі

Чухно Юлія Василівна, vasilivna2807@ukr.net, магістр

Київський національний університет імені Тараса Шевченка, Інститут філологі

У статті проаналізовано давньогрецькі крилаті вислови і гноми, що репрезентують уявлення про жінку, та виокремлено паремії з мізогіністичним змістом. У ході дослідження встановлено, щуо з чотирьох тисяч давньогрецьких паремій лише шістдесят п'ять одиниць вербалізують уявлення про жінку, щчо складає 1,6 \% від загальної кількості. Частина цих паремій репрезентують уявлення про жіночий характер, частина - про сочіальну роль жінки як дружини. Визначено, що у проаналізованих пареміях засвідчене мізогіністичне сприйняття жінки крізь призму чоловічого погляду на дійсність. У пареміях представлені уявлення про недосконалість жіночої природи та дефективність жіночого характеру. Жінка постає нестримною, балакучою, зрадливою, підступною, хитрою, мстивою, жадібною, тобто такою, що постійно загрожуе душевній рівновазі і статкам чоловіка. "Жінка" $i$ “жіночність" вважаються атрибутом дефективних рис характеру. Внаслідок аналізу мовного матеріалу зроблено висновок, щчо негативними рисами жіночої вдачі є хитрість, підступність, легковажність, мстивість, владність, дикий норов, балакучість, допитливість, заздрісність, лінивість, боягузтво, жадібність, розбещеність, нескромність, безсоромність, спокусливість, хвалькуватість, недобросовісність $і$ невміння керувати господарством. Лише незначна кількість паремій репрезентують уявлення про шлюб та роль жінки як дружини-господині. Шлюб є лише вимушеним кроком чоловіка заради народження законних громадян полісу. Відтак, жінка у мовній свідомості давніх греків постає як каһ̀̀v како́v “добре / необхідне зло” з огляду на

Актуальні проблеми мовознавства [Актуальные проблемы языкознания] (C Левко О. В., Чухно Ю. [Левко А В., Чухно Ю.], o.levko@knu.ua, vasilivna2807@ukr.net Вербалізація мізогіністичних уявлень у давньогрецьких пареміях [Вербализация мизогинистических представлений в древнегреческих паремиях] (Українською / На укр. яз) 
іï роль у продовженні роду. У статті встановлено, щзо витоки мізогіністичних уявлень сягають образу міфічної Пандори, на яку була покладена відповідальність за світове зло і страждання людей. Мізогіністичні уявлення також представлені у художній, філософській і медичній літературі Давньої Греції. У праиях Аристотеля та Гіппократа обтрунтовано нерівність жінки та чоловіка. Жінка є нижчою істотою, ніж чоловік, щчо проявляється у душевній природі, будові тіла і навіть ролі у народженні дітей.

Ключові слова: паремія, жінка, илюб, мізогінізм, гендер, давньогрецька мова.

\title{
ВЕРБАЛИЗАЦИЯ МИЗОГИНИСТИЧЕСКИХ ПРЕДСТАВЛЕНИЙ В ДРЕВНЕГРЕЧЕСКИХ ПАРЕМИЯХ
}

\author{
Левко Александр Вадимович, o.levko@knu.иа, \\ канд. филол. наук, доц. \\ Киевский национальный университет имени Тараса Шевченко, \\ Институт филологии \\ Чухно Юлия Васильевна, vasilivna2807@ukr.net, \\ магистр \\ Киевский национальный университет имени Тараса Шевченко, \\ Институт филологии
}

В статье проанализированы древнегреческие крылатые выражения $и$ гномы, которые репрезентируют представления о женшине, и выделены паремии с мизогинистическим содержанием. В ходе исследования установлено, что из четырех тысяч древнегреческих паремий только шестьдесят пять единич вербализируют представления о женщине, что составляет 1,6\% от общего количества. Часть этих паремий репрезентирует представления о женском характере, часть - о сочиальной роли женщины как жены. Проанализированные паремии свидетельствуют о мизогинистическом восприятии женщины сквозь призму мужского взгляда на действительность. В паремиях репрезентировань представления о несовершенстве женской природы и дефективности женского характера. Женщина изображается разговорчивой, неверной, коварной, хитрой, мстительной и жадной, то есть такой, которая постоянно угрожает душевному равновесию и богатству мужа. "Женщина" $u$ "женственность" считаются атрибутом дефективных черт характера. Анализ языкового материала продемонстрировал, что к негативным чертам женского характера относятся хитрость, коварство, легкомьслие, мстительность, властность, дикий нрав,

Actual Problems of Linguistics [Aktual'ni problemy movoznavstva] (C)Levko O., Chukhno Yu. [Levko O.V., ChuhnoJu.], o.levko@knu.ua,vasilivna2807@ukr.net Verbal Representation of Misogynistic Ideas in Ancient Greek Proverbs [Verbalizacija mizoginistychnyh ujavlen' u davn'ogrec'kyh paremijah] (in Ukrainian) 
болтливость, любопытство, завистливость, леность, трусость, жадность, распущенность, нескромность, бесстылство, соблазнительность, хвастовство, недобросовестность и неумение управлять хозяйством. Лишь незначительное количество паремий вербализируют представления о браке и роли женщинь как жены-хозяйки. Брак является вынужденным шагом мужа ради рождения законных граждан полиса. Поэтому женщина в языковом сознании древних греков выступает как каһ̀̀v како́v "хорошее / необходимое зло". В статье обосновывается, что мизогинистические представления древних греков связаны с образом мифической Пандоры, на которую была возложена ответственность за мировое зло и страдания людей. Мизогинистические представления также засвидетельствованы в художественной, философской и медицинской литературе Древней Греции. В трудах Аристотеля и Гиппократа обосновано неравенство женщины и мужчины. Женщина является низшим созданием по сравнению с мужчиной, что проявляется в ее душевной природе, строении тела и роли в рождении детей.

Ключевые слова: паремия, женщина, брак, мизогинизм, гендер, древнегреческий язык.

\title{
VERBAL REPRESENTATION OF MISOGYNISTIC IDEAS IN ANCIENT GREEK PROVERBS
}

\author{
Levko Oleksandr Vadymovych, o.levko@knu.ua, \\ $\mathrm{PhD}$, Associate Professor \\ Taras Shevchenko National University of Kyiv, \\ Institute of Philology
}

\section{Chukhno Yuliia Vasylivna, vasilivna2807@ukr.net, Master of Philology Taras Shevchenko National University of Kyiv, Institute of Philology}

The article deals with Ancient Greek aphorisms and gnomes representing the notion of woman, with a particular focus on the proverbs with misogynistic meaning. As a result of our analysis, it was found out that out of four thousand Ancient Greek proverbs under study only sixty-five units verbalize the notion of woman, making up $1.6 \%$ of the total count. Some of these proverbs represent the idea of female character, while others are related to the social role of women as wives. It is determined that the proverbs under study reveal the misogynistic perception of woman through the prism of a masculine point of view. The proverbs convey the idea of feminine nature's imperfection and the deficiency

Актуальні проблеми мовознавства [Актуальные проблемы языкознания] (C Левко О. В., Чухно Ю. [Левко А В., Чухно Ю.], o.levko@knu.ua, vasilivna2807@ukr.net Вербалізація мізогіністичних уявлень у давньогрецьких пареміях [Вербализация мизогинистических представлений в древнегреческих паремиях] (Українською / На укр. яз) 
of feminine character. Women come across as unrestrained, talkative, treacherous, insidious, cunning, vindictive, greedy, that is, as ones who constantly threaten the mental balance and the possessions of their husbands. "Woman" and "femininity" are envisaged as attributes of defective character traits. As a result of the analysis of the lingual material, it was concluded that the negative features attributed to the female nature are trickery, deceitfulness, frivolity, vengeance, authoritativeness, fierceness, talkativeness, intrusiveness, envy, laziness, cowardice, greed, vulgarity, indecision, shamelessness, temptation, boastfulness, unfairness and inability to manage the household. Only a small number of the proverbs under study convey the idea of marriage and the role of women as wives and mistresses of the house. Marriage is only a forced act for a man, which has as a purpose the birth of rightful citizens of the polis. Therefore, a woman in Ancient Greek

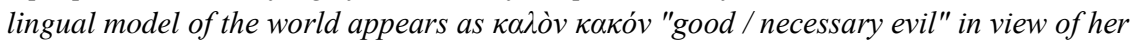
role in procreation. The study reveals that the origins of misogynistic ideas can be traced back to mythical Pandora, who was considered to be responsible for the inception of the world's evil and suffering of humanity. Misogynistic notions are also common in fiction, as well as philosophical and medical literature of Ancient Greece. In the works of Aristotle and Hippocrates, the inequality of women and men is substantiated. A woman is seen as inferior to man, which is allegedly evident in the mental nature of each, as well as the structure of their bodies and even their role in the childbirth.

Keywords: proverb, woman, marriage, misogyny, gender, Ancient Greek.

Вступ. У ХХ ст. наукова спільнота звернула увагу на гендерне питання. У рамках нової галузі знання - гендерології-стать почала вивчатися не лише за іiі анатомічними ознаками, а й за соціальними, економічними, правовими тощо. Закономірно, що гендерні дослідження торкнулися i колиски європейської цивілізації - античності. На матеріалі античних текстів питання статусу жінок вивчали у межах історії [Брюле 2005; Шарипкін 2011], філософії [Павлова 2009; Івченко 2014], культурології [Blundell 1995; Blundell 2008; Eaverly 2013], соціологіï [Cantarella 1987; Clark 1989; Schuller 2008] та лінгвістики [D’Ercole 2013]. У нечисленних лінгвістичних працях було доведено репрезентацію у мові дискримінації жінок, їх нерівного становища та незначної соціальної ролі. Наприклад, М. Д'Ерколь, проаналізувавши вибірку давньогрецьких слів на позначення жіночих занять, дійшла висновків, що тільки один із п'яти термінів існує у формі жіночого роду, що відповідно засвідчує гендерну орієнтацією мови на використання чоловічого роду [D’Ercole 2013, с. 53-71]. I хоча питання мізогінізму порушувалася у вище наведених наукових працях, проте його репрезентація у гномах,

Actual Problems of Linguistics [Aktual'ni problemy movoznavstva] (C)Levko O., Chukhno Yu. [LevkoO.V., ChuhnoJu.], o.levko@knu.ua,vasilivna2807@ukr.net Verbal Representation of Misogynistic Ideas in Ancient Greek Proverbs [Verbalizacija mizoginistychnyh ujavlen' u davn'ogrec'kyh paremijah] (in Ukrainian) 
пареміях і сентенціях - духовній скарбниці давніх греків - не була ще й досі досліджена, що й зумовлює актуальність даної статті.

Об'єкт і предмет, мета і завдання дослідження. Метою роботи $є$ дослідження вербалізації мізогіністичних уявлень у давньогрецькій лінгвокультурі. Об'єктом дослідження є репрезентація уявлень про жінку у давньогрецькій мовній картині світу. Предметом дослідження $\epsilon$ вербалізація мізогіністичних уявлень у давньогрецьких пареміях. Матеріали дослідження - корпус текстів давньогрецької мови Thesaurus Linguae Graecae (http://stephanus.tlg.uci.edu) та збірки давньогрецьких сентенцій.

Виклад основного матеріалу дослідження. Для античності було притаманним визнання нерівності жінок та чоловіків, вмотивоване їх "різною природою” [Костикова 2005, с. 19]. В античній культурі “жінки вважалися нижчими за природою і тому їхні функції обмежувалися дітонародженням та виконанням домашніх обов'язків" [Okin 1979, p. 16; цит. за: Костикова 2005, с. 19]. Філософське обгрунтування нерівності чоловіка і жінки знаходимо у працях Аристотеля. На його думку, чоловік і жінка, як вільна людина і раб, мають різну природу і не можуть бути рівними. В процесі зачаття чоловік дає дитині “форму”, тобто душу, а жінка тільки матерію, тобто тіло [Аристотель 1940, с. 90-91]. Оскільки душа за своєю природою - краща за тіло, то цілком правильним $\epsilon$ твердження, що жіноче й чоловіче начала $\epsilon$ нерівними [Костикова 2005, с. 20]. Відтак за Аристотелем, функція жінки з огляду на нижчість іiі природи полягає у виношуванні потомства. Вона також має займатися господарством, але ця функція другорядна і зумовлена тим, що люди живуть сім'ями [Павлова 2009, с. 183]. Есхіл в “Орестеі” називає жінку лише "нянею” майбутньої дитини, а сам плід $є$ продовженням чоловіка, що вказує на нижчість жінки у порівнянні з чоловіком навіть у дітонародженні:

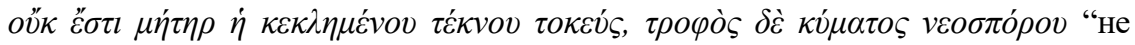
матір'ю $є$ та, що народила дитину, а годувальницею зачатого дитя” (Aesch. Eum. p. 657-661).

Яскравим прикладом мізогонізму є уявлення давніх греків про жіноче тіло. За Гіппократом, головна відмінність між жіночим та чоловічим тілом полягає у різній системі репродуктивних органів. Відповідно матка $€$ центром жіночої патології і причиною усіх жіночих хвороб, особливо коли вона розташована у жіночому тілі не на своєму місці (Hippocrates. De locis in homine, p. 47). Гіппократ підтримує припущення, що матка не має 
фіксованого місця у тілі, натомість вона “блукає” тілом у пошуках рідин і у такий спосіб зумовлює недосконалість жіночої природи. За Гіппократом, $\tau \grave{\nu} v$

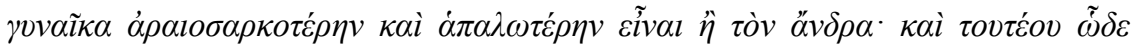

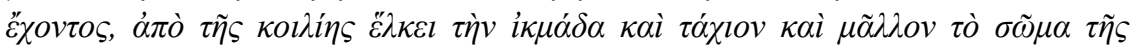

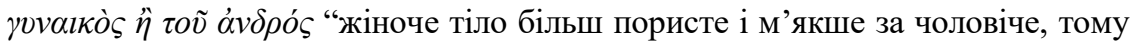
воно втягує вологу з живота швидше і краще, аніж чоловіче" (Hippocrates. De mulierum affectibus, 1.25-27). Більша кількість рідин спричиняє більшу кількість крові, яка спричиняє біль, якщо вчасно не вивільниться. Крім того, жіноча кров тепліша за чоловічу і переміщується швидше. Чоловіки не страждають від такого болю, бо їх тіло міцніше, і вони виконують більш складну роботу, тому рідини вивільняються швидше і не затримуються (Hippocrates. De mulierum affectibus 1.40-44). Отож, Гіппократ услід за іншими мислителями античності обгрунтовує нерівність жіночої і чоловічої природи навіть на анатомічному рівні.

За уявленнями давніх греків, не лише природа жінки була дефектною, а всі лиха на землі беруть початок від жінки. Б. Пауел стверджує: “Міф про Пандору, неначе біблійна історія про Адама і Єву, є етіологічним поясненням походження жінки, шлюбу і страждань у світі" [Powell 2015, p. 210]. За задумом Зевса Пандора стає покаранням за викрадення вогню Прометеєм. У поемі Гесіода "Роботи і дні” Зевс докоряє Прометею, що той перехитрив його і вкрав вогонь, за що Зевс наказує створити "злу річ для покарання смертних" (Hes. Opera at dies, p. 568-587). Попри те, що саме Прометей, чоловіче божество, розпочав протистояння богів і людей, ані його, ані Зевса ніколи не звинувачували у вивільненні зла. Приписування провини Пандорі є однією 3 найбільш патріархальних рис цього міфу, адже вона, незважаючи на роль жертви, визнається відповідальною за страждання та нещастя у світі. Однозначний образ Пандори як покарання для чоловіка проливає світло на особливості сприйняття жінки і iі характеру давніми греками. Жінка визнається “слабкою, мінливою і меркантильною” істотою, яка завдає шкоди чоловікам [Cantarella 1987, p. 28]. Х. Кінг стверджує: “Для греків жінки -

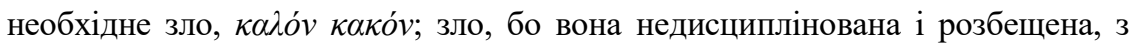
відсутністю самоконтролю, яким чудово володіє чоловік, але все ще потрібна у світі, сконструйованому чоловіком, щоб відтворювати його” [King 1983, p.110]. Такий погляд пояснює, чому жінки були обмежені сферою домашнього господарства. У межах дому жінку можна було стримувати i 
виховувати у ній покірність, підпорядкованість і смиренність.

Уявлення про недосконалість жіночої природи, а відтак - iї характеру, репрезентовані у давньогрецьких пареміях, як засвідчило наше дослідження. У багатьох пареміях представлені мізогіністичні уявлення, наприклад: $\eta$ $v v \eta ́$

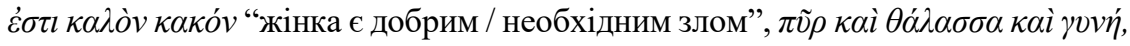

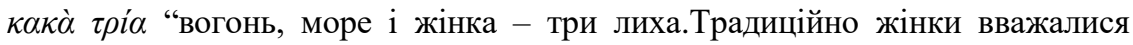
причиною різноманітних нещасть і небезпек через свій підступний шарм, який міг позбавити чоловіка здорового глузду. Згідно 3 проаналізованим матеріалом, однією з провідних властивостей жінки є їі балакучість і невміння дотримуватися таємниці. Паремії закликають не довіряти жінці, адже вона постійно плете інтриги і замислює зло. Гесіод застерігає чоловіків від лукавих жіночих слів і підступної (в́ліклолоv) натури (Hes. Opera et dies, p. 78).

Нами було проаналізовано близько 4000 давньогрецьких паремій, 3 яких виокремлено 65 одиниць, що репрезентують уявлення про жінку. Частина цих паремій вербалізує уявлення про жіночий характер, частина про соціальну роль жінки як дружини. У результаті аналізу паремій ми визначили такі негативні риси жіночої вдачі:

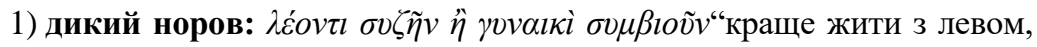

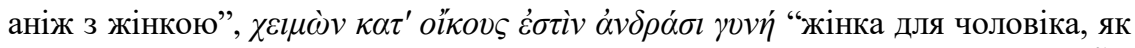

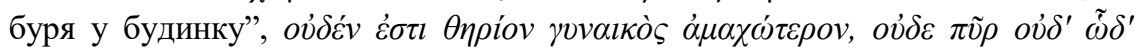

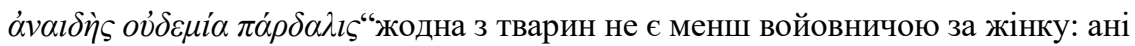
вогонь, ані настільки сміливий леопард";

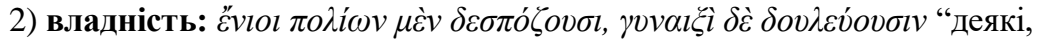
хоч і державами керують, перебувають у рабстві в жінок";

3) балакучість, допитливість: $\rho \alpha \tilde{\omega} v v \theta \lambda o l$ “бабські балачки”, $\pi \alpha ́ v \tau \alpha$

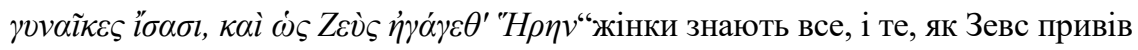
Геру";

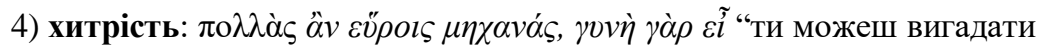
безліч хитрощів, оскількити жінка";

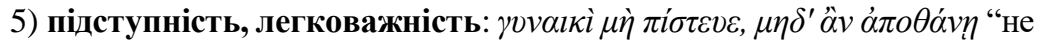

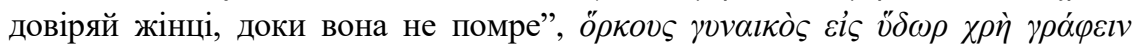

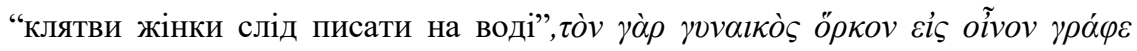
“клятви жінки пиши на вині”;

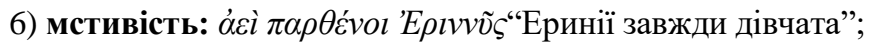

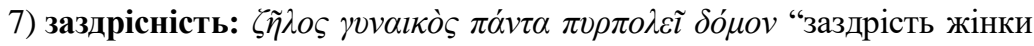


запалює увесь дім";

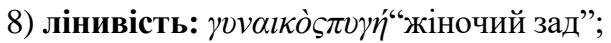

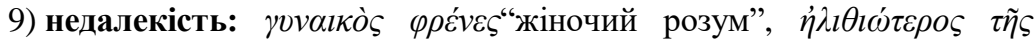

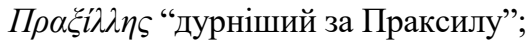

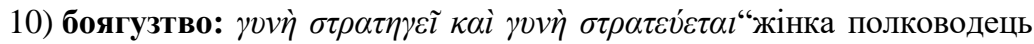

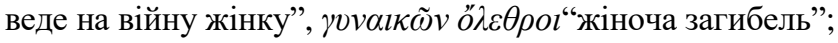

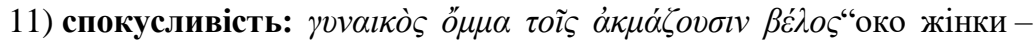

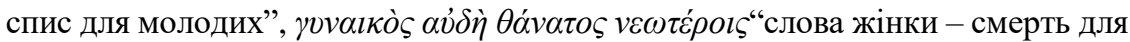
молодих";

12) розбещеність, нескромність, безсоромність: $\gamma \rho \alpha \tilde{v} \varsigma \dot{\alpha} v \alpha \theta v \tilde{\alpha}^{“ "}$ стара

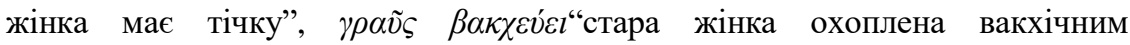

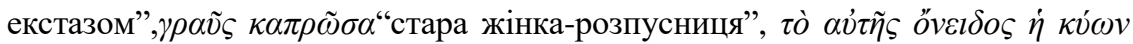

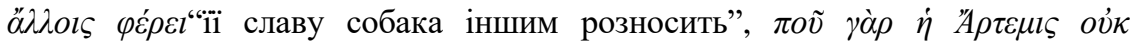

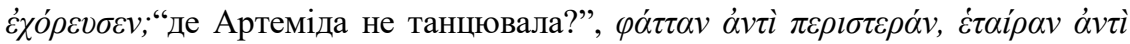
$v v ́ \mu \varphi \eta \varsigma^{\prime \prime} д и к о г о ~ г о л у б а ~ з а м і с т ь ~ г о р л и ц і, ~ г е т е р у ~ з а м і с т ь ~ н а р е ч е н о і ̈, ~ \gamma \rho \alpha \tilde{\varsigma ~}$

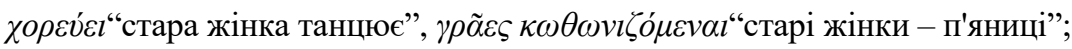

$13)$ недобросовісність, невміння керувати господарством: $\mu \eta \delta \varepsilon \dot{\pi} \tau \tau \varepsilon$

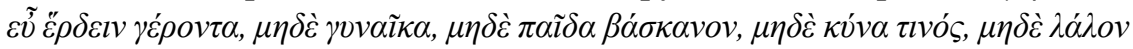

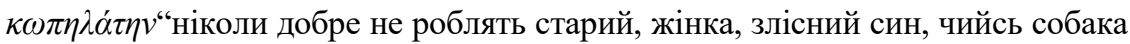

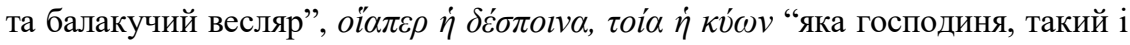

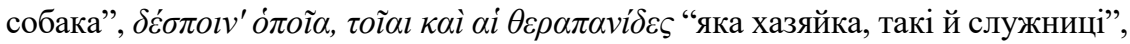

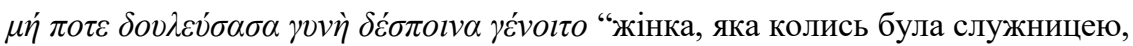
ніколи не буде господинею";

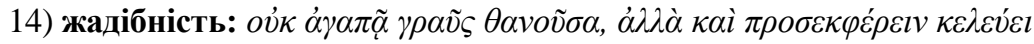
“помираюча стара не любить, але наказує принести";

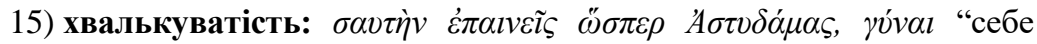
вихваляєш жінко, як Астидам".

Давньогрецькі паремії, як правило, описують жінку лише зайнятою господарством, дітьми і будинком, тобто жінку-дружину. Слід зазначити, що акцент зміщується на фінансову складову шлюбу. Утримання дружини представлене як тяжкий тягар, а багатша жінка накличе сором на чоловіка:

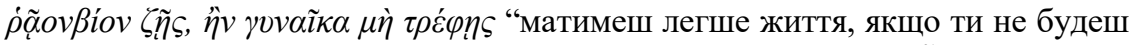

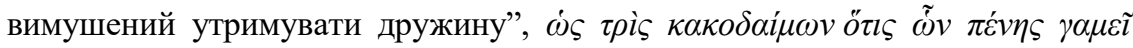

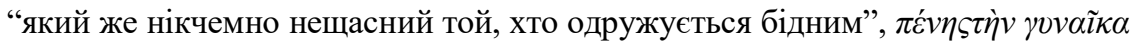

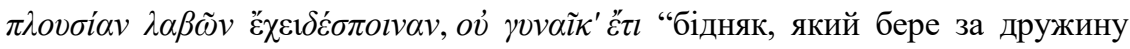


багату, матиме не дружину, а деспота", $\lambda \varepsilon v \kappa \omega ́ \lambda \varepsilon v o v ~ \lambda i v o v ~ \kappa \varepsilon \rho \delta o \gamma \alpha \mu \varepsilon \tilde{v}$ “одружуватися через розрахунок ізбілоруким льоном”, кє́ $\delta \delta \omega v ~ \gamma \alpha \mu \varepsilon \tilde{v}$

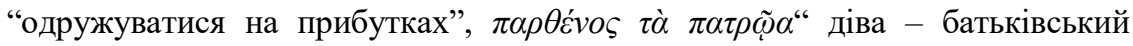
спадок".

Шлюб, як і жінка, був потрібен, у першу чергу, для народження законних громадян. Чоловіки ніяк не могли уникнути його, тому мусили миритися з усіма недоліками і перипетіями подружнього життя: $\dot{\gamma} \alpha \dot{\mu} о \varsigma$ $\gamma \grave{\alpha} \rho$

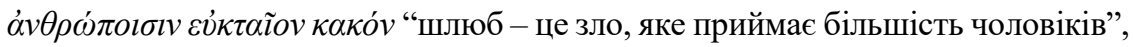

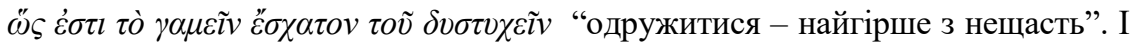
оскільки жінка була “необхідним злом” у чоловічому суспільстві, то іiі переваги чи недоліки визначалися саме на рівні суспільних характеристик, статусу, інакше жінки мало чим відрізнялися одна від одної, як засвідчує

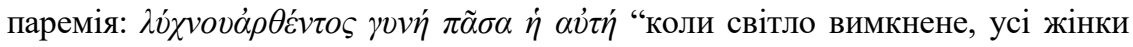
однакові”.

Висновки. У давньогрецьких пареміях, присвячених жінкам, засвідчене мізогіністичне сприйняття жінки крізь призму чоловічого погляду на дійсність. Жінка постає нестримною, балакучою, зрадливою, підступною, хитрою, мстивою, жадібною, тобто такою, що постійно загрожує душевній рівновазі і гаманцю чоловіка. “Жінка" і “жіночність” стають атрибутом неправильних, дефектних рис характеру. Лише незначна кількість паремій репрезентують уявлення про шлюб та роль жінки як дружини-господині. Шлюб є лише необхідним злом заради народження громадян полісу. Витоки жіночого зла сягають образу Пандори, яка була створена приносити нещастя, при цьому чоловіча роль в цій історії замовчується маскулінною літературою Греції, натомість уся відповідальність перекладається на плечі Пандори, а відповідно - жінок.

\section{Література:}

1. Брюле, П. Повседневная жизнь древнегреческих женщин в классическую эпоху,пер. с фр. Т. А. Левиной; под ред. А. В. Петрова (Москва, Молодая гвардия, 2005), 239.

2. Івченко, Ю. В.«Роль жінки в історії античної філософії.» Науковий вісник Ужгородського національного університету, Серія: Право29 (2/1)(2014): 12-14.

3. Костикова, И. В. (ред.) Введение в гендерные исследования (Москва, Аспект Пресc, 2005), 255.

4. Павлова, О. Н. «Философия античности: женщина как странный объект 
мышления.» Вестник Московского государственного областного университета, Серия: Философские науки 3(2009): 182-188.

5. Шарипкін, С. Я. «Відголоски матріархату в “Одіссеї”.» Науковий вісник Чернівецького університету, Серія: Романо-слов'янськийдискурс 565(2011): 221-228.

6. Blundell, S. Women in Ancient Greece(London, British Museum Press, 1995), 224.

7. Blundell S.,Rabinowitz N. S. «Women's bonds, women's pots: Adornment scenes in ancient Attic vase-painting.» Pheonix 62, No. 1/2(2008): 115-144.

8. Cantarella, E. Pandora's Daughters: The Role and Status of Women in Greek and Roman Antiquity (Baltimore, Johns Hopkins University Press, 1987), 229.

9. Clark, G.Women in the Ancient world (Oxford, Oxford University Press for the Classical Association, 1989), 46.

10. D’Ercole, M. C.«Marchands et marchandes dans la société grecque classique.»Des femmes en action. L'individu et la fonction en Grèce antique, Mètis Hors série, éd. S. Boehringer, V. Sébillotte Cuchet (Paris, 2013): 53-71.

11. Eaverly, M. Tan Men / Pale Women: Color and Gender in Archaic Greece and Egypt, a Comparative Approach(Ann Arbor, University of Michigan Press, 2013),192.

12. King, H.«Bound to Bleed: Artemis and Greek Women.»Images of Women in Antiquity, ed. A. Cameron and A. Kuhrt (London, Routledge, 1983): 109-127.

13. Okin, S.Women in Western Political Thought (Princeton, Princeton University Press, 1979),440.

14. Powell, B. B. Classical Myth, 8-th ed. (Boston, Pearson, 2015), 741.

15. Schuller, W.Die Welt der Hetären: Berühmte Frauen zwischen Legende und Wirklichkeit (Stuttgart, Klett-Cotta, 2008), 303.

\section{Список джерел ілюстративного матеріалу:}

16. Аристотель. О возникновении животных (Москва-Ленинград, Издательство Академии наук СССР, 1940), 250.

17. Гиппократ. Сочинения,кн. 1, Избранные книги, пер. В. И. Руднева, комм. В. П. Карпова (Москва, Биомедгиз, 1936), 736.

18. Лазер-Паньків, О. В. ПАРОІМІАI ЕААНNIКАI: Давньогрецькі прислів'я та приказки (Київ, ВПЦ «Київський університет», 2015), 447.

19. Baker, D. S.Greek proverbs (Belfast, Appletree press, 2007), 71.

20. Riley, H. T. A Dictionary of Latin and Greek Quotations, Proverbs, Maxims and Mottos (London, Bell, 1909), 622.

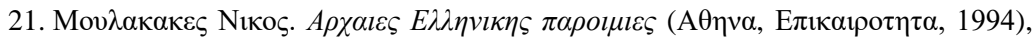
230.

\section{References:}

1. Briule, P. Povsednevnaia zhyzn drevnegrecheskikh zhenshchin v klassicheskuiu epokhu [Everyday Life of the Ancient Greek Women in the Classical Age](Moskva, Molodaia gvardiia, 2005), 239 (In Rus.).

Actual Problems of Linguistics [Aktual'ni problemy movoznavstva] (C)Levko O., Chukhno Yu. [LevkoO.V., ChuhnoJu.], o.levko@knu.ua,vasilivna2807@ukr.net Verbal Representation of Misogynistic Ideas in Ancient Greek Proverbs [Verbalizacija mizoginistychnyh ujavlen' u davn'ogrec'kyh paremijah] (in Ukrainian) 
2. Ivchenko, Yu. V. «Rol zhinky v istorii antychnoi filosofii [The Role of a Woman in Ancient Philosophy].» Naukovyi visnyk Uzhhorodskoho natsionalnoho universytetu, Seriia: Pravo29 (2/1) (2014): 12-14 (In Ukr.).

3. Kostikova, I. V. (red.) Vvedeniie v gendernyie issledovaniia [Introduction to Gender Studies](Moskva, Aspekt Press, 2005), 255 (In Rus.).

4. Pavlova, O. N.«Filosofiia antichnosti: zhenshchina kak strannyi obiekt myshleniia [Philosophy of Antiquity: Woman as a Strange Object of Cognition].» Vestnik Moskovskogo gosudarstvennogo oblastnogo universiteta, Seriia: Filosofskiie nauki 3 (2009): 182-188 (In Rus.).

5. Sharypkin, S. Ya. «Vidholosky matriarkhatu v "Odissei” [Echoes of matriarchate in “Odyssey”].» Naukovyi visnyk Chernivetskoho universytetu, Seriia: Romano-slovianskyi dyskurs 565(2011): 221-228 (In Ukr.).

6. Blundell, S. Women in Ancient Greece (London, British Museum Press, 1995), 224.

7. Blundell S., Rabinowitz N. S. «Women's bonds, women's pots: Adornment scenes in ancient Attic vase-painting.» Pheonix 62, No. 1/2 (2008): 115-144.

8. Cantarella, E. Pandora's Daughters: The Role and Status of Women in Greek and Roman Antiquity (Baltimore, Johns Hopkins University Press, 1987), 229.

9. Clark, G.Women in the Ancient world (Oxford, Oxford University Press for the Classical Association, 1989), 46.

10. D’Ercole, M. C.«Marchands et marchandes dans la société grecque classique.» Des femmes en action. L'individu et la fonction en Grèce antique, Mètis Hors série, éd. S. Boehringer, V. Sébillotte Cuchet (Paris, 2013): 53-71.

11. Eaverly, M. Tan Men / Pale Women: Color and Gender in Archaic Greece and Egypt, a Comparative Approach (Ann Arbor, University of Michigan Press, 2013),192.

12. King, H.«Bound to Bleed: Artemis and Greek Women.»Images of Women in Antiquity, ed. A. Cameron and A. Kuhrt(London, Routledge, 1983): 109-127.

13. Okin, S. Women in Western Political Thought (Princeton, Princeton University Press, 1979),440.

14. Powell, B. B. Classical Myth, 8-th ed. (Boston, Pearson, 2015), 741.

15. Schuller, W. Die Welt der Hetären: Berühmte Frauen zwischen Legende und Wirklichkeit (Stuttgart, Klett-Cotta, 2008),303.

16. Аристотель. О возникновении животных (Москва-Ленинград, Издательство Академии наук СССР, 1940), 250.

17. Гиппократ.Сочинения, кн. 1, Избранные книги, пер. В. И. Руднева, комм. В. П. Карпова (Москва, Биомедгиз, 1936), 736.

18. Лазер-Паньків, О. В. ПАРОІМІАI ЕАЯНNIКАI: Давньогрецькі прислів'я та приказки (Київ, ВПЦ «Київський університет», 2015), 447.

19. Baker, D. S. Greek proverbs (Belfast, Appletree press, 2007), 71.

20. Riley, H. T.A Dictionary of Latin and Greek Quotations, Proverbs, Maxims and Mottos (London, Bell, 1909), 622.

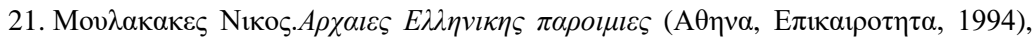
230.

Актуальні проблеми мовознавства [Актуальные проблемы языкознания]

(C Левко О. В., Чухно Ю. [Левко А В., Чухно Ю.], o.levko@knu.ua,vasilivna2807@ukr.net

Вербалізація мізогіністичних уявлень у давньогрецьких пареміях [Вербализация мизогинистических представлений в древнегреческих паремиях] (Українською / На укр. яз) 


\title{
ФУНКЦІЇ МОВЛЕННСВИХ ЖАНРІВ У ТЕКСТАХ ФРАНЦУЗЬКИХ POMAHIB XX ст.
}

\author{
Лепетюк Ірина Григорівна, irina@prevalex.com \\ канд. філол. наук, доц. \\ Київський національний університет імені Тараса Шевченка, \\ Інститут філології
}

\begin{abstract}
Дослідження базується на теорії мовленнєвих жанрів Бахтіна М. М., згідно з якою будь яка комунікачія, включаючи художню комунікачію, реалізується через мовленнєві жанри. Художня комунікачія розглядається як вторинний мовленнєвий жанр, який з'являється в умовах культурної комунікації $і$ в процесі творення використовує первинні мовленнєві жанри. Стаття представляє результати дослідження місия і ролі первинних мовленнєвих жанрів в структурі текстів франиузького роману XX cm. A саме - досліджується еволюиія появи мовленнєвих жанрів в текстах романів, їх форми присутності та їх функції. У статті аналізується семіотичний характер мовленнєвого жанру та взаємовплив мовленнєвого жанру та контексту мовленнєвої ситуачії. Досліджується використання французькими романістами мовленнєвого жанру для передачі імпліцитної інформації. На прикладі текстів франиузьких романів розглядаються та аналізуються види діалогізму. Це явище пов'язане з інтенціональним та сигніфікативним аспектами мови: кожна мова асоиіюється з певним образом мовия, відсилає до певного контексту і виражає точку зору і певне світобачення. Отже, текст роману може бути представленим як система різних мов, а також вставних мовленнєвих жанрів, що вступають у різні діалогічні взаємозв'язки, функиіонування яких зорганізоване $і$ скеровується автором згідно зі своїми інтенціями.
\end{abstract}

Ключові слова: дискурс, мовленнєвий жанр, художня комунікація, франиузький роман, вторинний мовленнєвий жанр, первинний мовленнєвий жанр, семіотика, поліфонія, діалогізм. 


\title{
ФУНКЦИИ РЕЧЕВЫХ ЖАНРОВ В ТЕКСТАХ ФРАНЦУЗСКИХ РОМАНОВ XX ст.
}

\author{
Лепетюк Ирина Григорьевна, irina@prevalex.com \\ канд. филол. наук, доц. \\ Киевский национальный университет имени Тараса Шевченко \\ Институт филологии
}

\begin{abstract}
Исследование основывается на теории речевых жанров М. М. Бахтина, по которой любая коммуникация, включая художественную коммуникацию, реализуется посредством речевых жанров. Художественная коммуникация рассматривается как вторичный речевой жанр, который в прочессе создания абсорбирует первичные речевые жанры. Статья представляет результаты исследования места и роли речевых жанров в структуре текста франиузского романа $X X$ в. Изучаются речевые жанры в тексте романа, формы их присутствия и функции. В статье анализируется семиотический характер речевого жанра и взаимовлияние речевого жанра $и$ контекста речевой ситуачии. Исследуется использование франиузскими романистами речевого жанра для передачи имплицитной информачии. На примере текстов франиузских романов рассматриваются и анализируются виды диалогизма. Это явление связано с интенциональным и сигнификативным аспектами речи: каждое высказывание ассочиируется с образом говорящего, отсылает $\kappa$ определенному контексту и выражает определенную точку зрения и мировоззрение. Таким образом, текст романа может быть представлен как система разных голосов, а также вставных жанров, которые вступают в разные диалоговые взаимосвязи, функиионирование которых организовано и регулируется самим автором соответственно его интенциям.
\end{abstract}

Ключевые слова: дискурс, речевой жанр, художественная коммуникация, культурная коммуникачия, вторичный речевой жанр, первичный речевой жанр, семиотика, полифония, диалогизм.

\section{THE FUNCTIONS OF SPEECH GENRES IN THE FRENCH NOVEL OF THE XX-th CENTURY.}

\author{
Lepetiuk I., irina@prevalex.com
}

PhD., Associative Professor

Taras Shevchenko National University of Kyiv,

Institute of Philology

The research is based on the M. Bakhtin's theory of the speech genres, according

Актуальні проблеми мовознавства [Актуальные проблемы языкознания]

(С Лепетюк I. Г. [Лепетюк И. Г.], irina@prevalex.com

Функції мовленнсвих жанрів в текстах французьких романів XX ст. [Функции речевых жанров в

текстах французских романов XX ст.] (Французькою / На франц. яз) 
to which speech communication, including artistic communication, is realized through a variety of genres of speech. The artistic text is considered as a secondary speech genre, which arises in the conditions of cultural communication and in the process of its formation absorbs a variety of primary genres. The article presents the results of investigation of the plays and role of speech genres in the structure of French novel of $X X$ c. It examines different forms of the presence of a great variety of speech genres in the novel as well as their functions. This article analyzes a semiotic character of a speech genre and interference of a speech genre and a context of a speech situation. It investigates the use by the French novelists of a speech genre for transfer implicit information. The dialogism is examined and analyzed in the text of French Novel. This phenomenon is associated with the intentional and synthetic aspects of the language: each language is associated with a certain form of the speaker, refers to a certain context and expresses the point of view and a certain world outlook. Consequently, the text of the novel may be presented as a system of different languages, as well as inserted speech genres, entering into various dialogical interactions, the functioning of which has been organized and directed by the author in accordance with their intentions.

Keywords: discourse, speech genre, artistic communication, French novel, secondary speech genre, primary genre, semiotic, polyphony, dialogism.

\title{
LE FONCTIONNEMENT DES GENRES DU DISCOURS DANS LES TEXTES DES ROMANS DU XX s.
}

\author{
Lepetiuk I., irina@prevalex.com \\ Docteur de l'Univercité Paul Valéry Montpellier III, Maître des conférences \\ Université nationale Taras Chevtchenko de Kiev, \\ L'Institut de Philologie
}

A l'origine de notre recherche il y a une idée de vérifier et d'approfondir l'hypothèse bakhtinienne selon laquelle le texte romanesque absorbe et assimile au cours de son élaboration de nombreux genres du discours qui se trouvent modifiés à leur tour dans le contexte de l'œuvre littéraire. Pour l'objet de notre analyse nous avons choisi les textes des romans du XX-e siècle. En présentant la notion du genre du discours il faut mentionner que d'après $M$. Bakhtine toute notre acivité langagière se réalise selon les modèles préétablis qui sont les genres du discours. On distinge les genres du discours premiers et les genres du discours seconds. La communication artistiqe est considérée comme le genre du discours second qui absorbe et recycle au cours de sa création les genres du discours premiers. Nous analysons la place et le rôle de différents genres du discours dans la structure des textes littéraire. L'accent particulier est mis sur leur caractère sémiotique et intertextuel ainsi que sur leur capacité de véhiculer pour le lecteur 
l'information implicite. On étudie aussi les rapports dialogiques et différents aspect de la polyponie ainsi que la présentation de la réalité à traves les genres du discours. De differentes fonctions des genres du discours dans le texte littéraire sont aussi analysées.

Mots clé : discours, genre du discours, communication artistique, le roman français, genre du discours premier, genre du discours second, sémiotique, polyphonie, dialogisme.

\section{La notion du genre du discours.}

Selon le linguiste russe M. Bakhtine, la parole est individuelle, mais en même temps elle est normalisée. Si la langue est un système de formes normalisées, l'activité discursive a aussi ses formes de communication relativement stables et fixées. M. Bakhtine appelle ces formes stables de communication - les genres du discours (GD): «chacun des types de communication sociale (...) organise, construit et achève, de façon spécifique, la forme grammaticale et stylistique de l'énoncé ainsi que la structure du type dont il relève: nous la désignerons désormais sous le terme de genre » (Todorov, 1981, 290). Dans son article sur le problème du texte, M. Bakhtine a défini les genres du discours comme « les modèles-types de construction d'un tout verbal » (Bakhtine, 1984, 338). Comme J.-M. Adam l'a remarqué, « avec la notion de «genre de discours », ce qui est mis en avant c'est l'existence de pratiques discursives réglées » (Adam, 1991, 27).

Le répertoire des GD est très grand et varié. L'énorme variété et la quantité inépuisable des GD sont expliquées par une grande variété de tous les types de l'activité humaine. En même temps, il faut souligner que chaque sphère dispose d'un ensemble de genres du discours qui évolue et s'enrichit avec elle. Une conversation familière, un entretien d'affaires, un discours scientifique, une lettre intime, un télégramme, une annonce publicitaire, une émission radiophonique, des ouvrages scientifiques, des œuvres littéraires etc. présentent, d'après Bakhtine, de nombreux genres du discours oraux et écrits formant les types différents de communication langagière.

Mais dans son article «Les genres du discours », il a proposé et décrit d'une manière détaillée la division des GD en deux groupes - les genres du discours premiers et les genres du discours seconds (GDs).

Les genres du discours premiers appartiennent à la sphère de l'activité langagière de la vie courante. Ils appartiennent à toutes les sphères de la communication courante - familière et officielle, professionnelle et quotidienne. 
« Les genres seconds du discours - le roman, le théâtre, le discours scientifique, le discours idéologique etc. - apparaissent dans les circonstances d'un échange culturel (principalement écrit) - artistique, scientifique, socio-politique - plus complexe et relativement plus évolué » (Bakhtine, 1984, 267). Le savant a aussi caractérisé les genres du discours premiers comme simples et les genres du discours seconds comme complexes car les derniers « au cours du processus de leur formation [...] absorbent et transmutent les genres premiers de toutes sortes, qui se sont constitués dans les circonstances d'un échange verbal spontané » (Bakhtine, 1984, 267). Cela concerne surtout le roman dont la structure est constituée de plusieurs genres premiers absorbés et transformés.

\section{Les GD dans la structure textuelle des romans du XXe siècle.}

$\mathrm{Si}$ au $\mathrm{XVIII}^{\mathrm{e}}$ siècle, les romanciers cherchaient à conférer au roman la caution du «vrai» et indiquaient eux-mêmes le genre dans lequel ils « déguisaient» leur texte - le mémoire, le journal intime, la correspondance, au $\mathrm{XX}^{\mathrm{e}}$ siècle l'appartenance du texte à un genre concret n'est pas évidente même s'il s'agit de la forme de l'autobiographie, comme, par exemple, La vie en fleur d'Anatole France ou A la recherche du temps perdu de Marcel Proust. ${ }^{1}$ Un autre exemple: La Chute d'Albert Camus. Ce roman est conçu comme un monologue-confession, mais en même temps, nous pouvons le considérer comme une partie d'un dialogue où les répliques de l'interlocuteur sont absentes de facto mais présentes potentiellement. Examinons quelques fragments de ce roman :

Ferez-vous un long séjour à Amsterdam? Belle ville, n'est-ce pas ? Fascinante ? Voilà un adjectif que je n'ai pas entendu depuis longtemps. Depuis que j'ai quitté Paris, justement, il y a des années de cela.

Mais permettez-moi de me présenter: Jean-Baptiste Clamence, pour vous servir. Heureux de vous connaître. Vous êtes sans doute dans les affaires? A peu près? Excellente réponse! Judicieuse aussi ; nous sommes qu'à peu près en toutes choses. »

\footnotetext{
${ }^{1}$ Madeleine Borgomano et Ravoux Rallo caractérisent $A$ la recherche du temps perdu comme genre «de l'entre-deux, ni autobiographie ni roman mais l'un et l'autre». M. Borgomano, E. Ravoux Rallo La littérature française du XX $X^{e}$ siècle. 1. Le roman et la nouvelle, Paris : Armand Colin, 1995, p. 27.
} 
Nous voyons bien que l'énoncé du personnage (ici nous avons présenté deux fragments de cet énoncé-monologue qui constitue le texte du roman) en réalité inclut plusieurs énoncés qui font partie du dialogue. Ce sont les énoncésinterrogations et les énoncés-confirmations, les réactions aux réponses reçues. D'après ces énoncés, il est facile de reconstituer au moins le contenu des répliques de l'interlocuteur potentiel.

Le récit romanesque peut être aussi constitué d'une suite des GD différents. Comme, par exemple, le roman d'Hervé Bazin Lève-toi et marche qui commence comme un monologue (ou plutôt soliloque) de l'héroïne principale et se termine par le récit du père Roquault, rédigé sous forme de journal intime. Ou le roman de François Mauriac Le næud de vipères où la première partie est écrite comme une lettre du personnage adressée à sa femme, la deuxième partie nous rappelle plutôt le journal intime, et les lettres, écrites par son fils et sa fille, constituent l'épilogue ironique de cette œuvre.

Très souvent le texte romanesque est présenté comme une structurehybride, le mélange de plusieurs GD : dans Les Conquérants d'André Malraux, nous distinguons les traits qui sont caractéristiques du journal intime, du reportage ; on trouve également les intrusions des émissions de radio, des ordres militaires, des télégrammes. Parfois cela ressemble à un collage ou à un montage.

Nombreux sont les cas où la structure textuelle du roman est constituée de GD qui fusionnent, se croisent et s'emboîtent. Dans le roman Thérèse Desqueyroux de François Mauriac, le récit est construit comme la fusion, l'amalgame des narrations de la première et de la troisième personne. Ce sont deux voix qui s'entremêlent : celle de l'auteur et celle de l'héroïne

Nous trouvons une vraie polyphonie et l'orchestration de plusieurs voix dans Les Faux-Monnayeurs d'André Gide où le récit se tisse à partir de la narration de l'auteur, des lettres des personnages, du journal d'Edouard, des notes qu'il prend à propos de l'art romanesque et du roman écrit par Edouard. La présence dans la structure narrative du roman de l'ouvrage écrit (Les FauxMonnayeurs d'André Gide ou La Nausée de Jean-Paul Sartre) ou lu par le personnage (L'Emploi du temps de Michel Butor) est assez fréquente au $\mathrm{XX}^{\mathrm{e}}$ siècle. Dans Les Faux-Monnayeurs d'André Gide et L'Emploi du temps de 
Michel Butor ces GDs faux servent de miroir aux événements qui se déroulent dans la réalité « vraie » du roman et créent « la mise en abyme »- un type de construction romanesque qui donne beaucoup de profondeur au champ narratif.

$\mathrm{Au} \mathrm{XX}^{\mathrm{e}}$ siècle, nous découvrons une autre particularité inédite du rôle des GD dans la composition romanesque : ils font non seulement partie de la structure du récit mais ils servent à la construction et au développement de la narration comme par exemple, cette lettre reçue par le narrateur dans ce fragment de La Nausée de Sartre :

Je sors; je tiens l'enveloppe entre mes doigts, je n'ose pas l'ouvrir ; Anny n'a pas changé son papier à lettres, je me demande si elle l'achète toujours dans la petite papeterie de Piccadilly. Je pense qu'elle a conservé sa coiffure, ses lourds cheveux blonds qu'elle ne voulait pas couper. Elle doit lutter patiemment devant les miroirs pour sauver son visage : ce n'est pas coquetterie ni crainte de vieillir; elle veut rester comme elle est, tout juste comme elle est. C'est peut-être ce que je préférais en elle, cette fidélité puissante et sévère au moindre trait de son image.

Les lettres fermes de l'adresse, tracées à l'encre violette (elle n'a pas changé l'encre non plus) brillent encore un peu.

« Monsieur Antoine Roquentin. »

Comme j'aime lire mon nom sur ces enveloppes. Dans un brouillard j'ai retrouvé un de ses sourires, j'ai deviné ses yeux, sa tête inclinée : quand j'étais assis, elle venait se planter devant moi en souriant. Elle me dominait de tout le buste, elle me saisissait aux épaules et me secouait à bras tendus.

L'enveloppe est lourde, elle doit contenir au moins six pages. Les pattes de mouches de mon ancienne concierge chevauchent cette belle écriture :

$$
\text { « Hôtel Printania - Bouville. » }
$$

Ces petites lettres ne brillent pas.

Quand je décachette la lettre, ma désillusion me rajeunit de six 
ans :

« Je ne sais comment Anny peut s'y prendre pour gonfler ainsi ses enveloppes : il n'y a jamais rien dedans. »

Cette phrase, je l'ai dite cent fois au printemps de 1924, en luttant, comme aujourd'hui, pour extraire de la doublure un bout de papier quadrillé. La doublure est une splendeur vert sombre avec des étoiles d'or ; on dirait une lourde étoffe empesée. A elle seule, elle fait les trois quarts du poids de l'enveloppe.

Anny a écrit au crayon :

« Je passerai à Paris dans quelques jours. Viens me voir à l'hôtel d'Espagne, le 20 février. Je t'en prie (elle a ajouté « je t'en prie » au-dessus de la ligne et l'a rejoint à «me voir » par une curieuse spirale). Il faut que je te voie. Anny. »

A Meknès, à Tanger, quand je rentrais, le soir, je trouvais parfois un mot sur mon lit : « Je veux te voir tout de suite. » Je courrais, Anny m'ouvrait les sourcils levés, l'air étonné : elle n'avait plus rien à me dire ; elle m'en voulait un peu d'être venu. J'irai. Peutêtre qu'elle refusera de me recevoir.

(Sartre, La Nausée, 90-91)

Nous nous sommes permis de citer ce long et beau morceau du roman pour montrer comment le GD peut générer la narration. Au fur et au mesure de l'ouverture de l'enveloppe et de la lecture de la lettre, chaque petit détail - le papier, l'écriture, le contenu du message - évoque dans la mémoire du personnage l'image de sa femme, les épisodes de leur vie ; ils renvoient à un autre énoncé, dit autrefois, et à un autre billet. Tout cela constitue la narration le monologue intérieur du personnage-narrateur.

Un autre exemple - Les Conquérants d'André Malraux où des bribes d'actualités, diffusées par la radio, « ouvrent » des inscriptions journalières du personnage dans son journal intime, apportent du dynamisme au récit et rythment en quelque sorte la narration.

Le fait principal que nous voulons souligner, c'est qu'au $\mathrm{XX}^{\mathrm{e}}$ siècle les romanciers utilisent beaucoup plus les sources du langage et très souvent les GD deviennent l'enjeu principal de l'esthétique du texte romanesque. En même temps, nous pouvons constater l'élargissement du répertoire des GD insérés dans la structure romanesque. 


\section{Les fonctions de GD dans les romans du XXe siècle.}

A part la présence dans la structure du roman, les GD sont aussi utilisés par les écrivains avec d'autres buts significatifs.

\subsection{La fonction informative.}

Envisageons un exemple intéressant tiré des Thibault de Martin du Gard - un télégramme et une carte envoyés par Mme de Fontanin le même jour :

Avant de rentrer chez elle, $\mathrm{M}^{\mathrm{me}}$ de Fontanin entra dans un bureau de poste, prit une feuille de télégramme, et écrivit:

« Victorine Le Gad. Place de l’Église, Perros-Guirec (Côtes-duNord).

Veuillez dire à M. de Fontanin que son fils Daniel a disparu depuis dimanche. »

Puis elle demanda une carte-lettre:

$$
\begin{gathered}
\text { «Monsieur le Pasteur Gregory, } \\
\text { Christian Scientist Society, } \\
2 \text { bis, boulevard Bineau, } \\
\text { Neuilly-sur-Seine. }
\end{gathered}
$$

Cher James,

Depuis deux jours Daniel est parti, sans dire où, sans donner de nouvelles; je suis rongée d'inquiétude. De plus, ma Jenny est malade, une grosse fièvre que rien n'explique encore. Et je ne sais où retrouver Jérôme pour le prévenir.

Je suis bien seule, mon ami. Venez me voir.

Thérèse de Fontanin

(Martin du Gard, Les Thibault, t. I, 41-42)

Dans ce fragment, l'auteur ne dit rien des relations qui existent entre Mme de Fontanin et son mari. Le lecteur peut bien en tirer ses propres conclusions en comparant ces deux textes concernant le même problème : la brièveté et le caractère officiel du premier et toute la sincérité, l'ouverture et 
l'appel à l'aide d'urgence que contient l'autre. En plus, le premier, bien qu'il s'agisse d'une information destinée à $\mathrm{M}$. de Fontanin, est adressé à une autre dame, ce qui explique implicitement la situation du couple à ce moment.

Le choix des GD différents est aussi significatif : un télégramme qui impose ses limites strictes de communication et une carte-lettre qui permet de communiquer beaucoup plus et d'une manière plus intime. C'est le caractère sémiotique du GD dont nous avons parlé qui permet de véhiculer pour le lecteur toutes sortes d'information, car le style et la construction de l'énoncé reflètent tous les facteurs de la situation communicative à laquelle il correspond et notamment les rapports entre les communicants. L'expérience et la compétence discursive du lecteur lui permettent de lire et de déchiffrer cette information implicite contenue dans la construction du GD. Cette utilisation de la valeur sémiotique du GD appartient aux mécanismes de transmission du message implicite au lecteur par le romancier. Dans le sous-chapitre qui suit nous allons examiner plus en détail ce phénomène ainsi que différents rapports dialogiques et intertextuels qui existent entre les GD et le texte du roman et qui servent aussi à la production des significations pour le lecteur.

3.2 La valeur sémiotique du $G D$.

Le texte, notamment littéraire, a été souvent l'objet de l'étude sémiotique. Selon Y. Lotman, et sa théorie de modélisation qui explique le caractère sémiotique du texte artistique :

Des systèmes modélisants secondaires représentent des structures, à la base desquelles se trouve la langue naturelle. Cependant, ultérieurement le système reçoit une structure complémentaire, secondaire, de type idéologique, éthique, artistique, ou de tout autre type. Les significations de ce système secondaire peuvent s'organiser selon des moyens propres aux langues naturelles, et selon des moyens d'autres systèmes sémiotiques (Lotman, 1973, 71).

Dans les ouvrages consacrés à la sémiotique littéraire le texte romanesque est souvent représenté comme une configuration des modélisations et comme le souligne W. Krysinski, « tout roman inscrit dans la chaîne évolutive actualise le code modélisant par une série des modélisations particulières qui en assurent la spécificité » (Krysinski, 1981, 5). C'est l'approche structurale qui est au fondement de l'étude sémiotique : la tentative de présenter le texte comme un 
ensemble d'unités formelles et significatives. Mais c'est plutôt les unités lexicales ou phonétiques, ou les isotopes sémantiques qui ont été toujours au centre d'intérêt des spécialistes de ce domaine. Mais c'est plutôt la dimension socio-culturelle de l'usage du discours (la possibilité de se référer aux classes ou groupes sociaux) et la valeur pragmatique (il s'agit de l'étude des actes de parole dans le texte littéraire) qui y sont mises en valeur. La question du rôle sémiotique du genre du discours pris dans son intégralité dans le texte romanesque n'a pas été posée ${ }^{2}$. Néanmoins dans l'article de F. Rastier nous trouvons des idées théoriques intéressantes qui correspondent entièrement à notre approche et à celle de Bakhtine :

...tout texte, par son genre, se situe dans une pratique. Le genre est ce qui permet de relier le contexte et la situation, car il est à la fois un principe organisateur du texte et un mode sémiotique de la pratique en cours. Les contingences normatives que sont les genres déterminent le rapport du texte à sa situation. En d'autres termes, le contexte situationnel agit par le biais du contexte linguistique et par la médiation de normes de genre. [...]

Les régimes interprétatifs des types de discours (politiques, religieux, etc.) sont enfin spécifiés par les contrats interprétatifs propres aux genres. A la conception syntaxique de l'interprétation, nous opposons qu'interpréter, c'est recontextualiser: ce qui sépare une interprétation d'un simple transcodage, c'est le changement de contexte. La relation $B$ réécrit $A$ doit devenir $B$ dans le contexte $Y$ réécrit $A$ dans le contexte $X$. (Rastier, 1988, 106-107)

C'est cette liaison entre la structure du GD et le contexte qui l'a engendré qui assure la signification sémiotique du GD. Ce que nous voudrions préciser et suggérer, comme hypothèse, c'est le fait que le lecteur, s'appuyant sur son expérience de la pratique discursive peut déduire, à partir du GD, présent dans le

\footnotetext{
2 Il faut signaler quand même un ouvrage très intéressant de L. Adert Les mots des autres, Paris : PUF, 1996, où l'auteur, en analysant les romans de Gustave Flaubert, s'inspire de l'approche bakhtinienne et parle de la dimension du code dans les genres du discours en tant que formes de la parole «socialement codifiée, ritualisée et institutionnalisée » (p. 50), mais la notion du genre du discours n'est pas bien déterminée (il parle en même temps des discours, des types des discours) et il n'entre pas dans le détail du fonctionnement du mécanisme de ce processus.
} 
texte littéraire, toute l'information concernant le contexte communicatif du GD, décrit dans notre schéma par trois groupes des facteurs: OS - le type des relations entre les interlocuteurs; $\mathrm{OP}$ - les buts pragmatiques et les sphères d'activité ; $\mathrm{OC}-$ les conditions de la communication. ${ }^{3}$

Cette information est véhiculée par l'image du GD qui s'associe dans la conscience du lecteur à certaine signification (une lettre d'amour, par exemple, ou une lettre de change qui appartiennent à des sphères complètement différentes dans notre conscience) et par les traits spécifiques des énoncés qui constituent ce GD.

Dans notre dernier exemple (le télégramme et la carte postale de Mme de Fontanin), nous venons de démontrer que ces deux GD contiennent une information concernant les relations de Mme de Fontanin avec les deux destinataires. Citons encore un exemple où le sens naît de la confrontation des deux sphères différentes.

\subsection{Le rôle des rapports dialogiques.}

Des rapports dialogiques surgissent souvent entre les GD dans le texte romanesque. Ces rapports occupent une place très importante dans le roman et constituent un des moyens de la production du sens complémentaire pour l'écrivain. Précisons très brièvement quels sont les types de rapports dialogiques qui peuvent exister entre les GD.

Nous venons de parler des rapports de confrontation et d'opposition. Ils peuvent se manifester non seulement comme l'opposition des différentes sphères auxquelles les GD appartiennent, mais ils peuvent être aussi construits sur une antithèse de forme ou de contenu. Voilà quelques exemples nous permettant mieux expliquer notre idée.

Cette complication des rapports dialogiques est très caractéristique des romans du $\mathrm{XX}^{\mathrm{e}}$ siècle où des liens sémantiques de caractères différents peuvent être établis entre plusieurs GD, comme dans un exemple, tiré de La Nausée de Jean-Paul Sartre, où les rapports dialogiques complexes se manifestent entre le dialogue des deux personnages au restaurant, le texte du menu, la commande et

3 Ce schéma de l'analyse du GD est présenté en détailles dans l'article de Lepetyuk I. La présentation schématique du genre du discours. Actes du colloque national des jeunes chercheurs (COLNAJEC). Université Paul Valéry Montpellier III, 2000, pp. 209-216. 
le monologue intérieur de l'un de ces personnages.

L'Autodidacte a sorti de son portefeuille deux rectangles de carton violet. Il les donnera tout à l'heure à la caisse. Je déchiffre à l'envers sur l'un deux :

Maison Bottanet, cuisine bourgeoise.

Le déjeuner à prix fixe : 8 francs.

Hors-d'œuvre au choix.

Viande garnie.

Fromage ou dessert.

140 francs les 20 cachets.

$[\ldots]$

L'Autodidacte rit avec innocence et le soleil se joue dans ses rares cheveux :

- Voulez-vous choisir votre menu ?

Il me tend la carte : j'ai droit à un hors-d'œuvre au choix : cinq rondelles de saucisson ou des radis ou des crevettes grises ou un ravier de célérie rémoulade. Les escargots de Bourgogne sont supplémentés.

- Vous me donnez un saucisson, dis-je à la bonne.

Il m'arrache la carte des mains :

N'y a-t-il rien de meilleur? Voilà des escargots de Bourgogne.

- C'est que je n'aime pas beaucoup les escargots.

- Ah! Alors des huîtres ?

- C'est quatre francs de plus, dit la bonne.

- Et bien, des huîtres, mademoiselle - et des radis pour moi.

Il m'explique en rougissant :

- J'aime beaucoup les radis.

Moi aussi.

- Et ensuite ? demande-t-il.

Je parcours la liste de viande. Le bœuf en daube me tenterait. Mais je sais d'avance que j'aurai du poulet chasseur, c'est la seule viande supplémentée.

- Vous donnerez, dit-il, un poulet chasseur à monsieur. Pour moi, un bœuf en daube, mademoiselle. 
(Sartre, La Nausée, 148-149)

Nous voyons bien que dans ce fragment du roman de Jean-Paul Sartre les deux GD - ticket de restaurant et commande du menu entrent en rapports dialogiques complexes: toute la conversation (la commande du menu) est construite à partir des conditions auxquelles le ticket est soumis. Mais en même temps, cette négociation délicate sert de caractéristique implicite des deux personnages qui ont tous les deux de bonnes intentions, mais différentes lignes de conduite. Et surtout elle ajoute beaucoup de nouveaux traits au portrait psychologique de l'Autodidacte.

Dans Les Conquérants d'André Malraux nous trouvons le cas de deux GD se trouvant en opposition du contenu. Il s'agit de deux affiches de propagande : l'une, distribuée par les contre-révolutionnaires, qui contenait le fragment final du testament de Tcheng-Daï et l'autre, proposée comme un acte de la contre-propagande par Garine :

« Note et traduit ceci :

"N'oublions jamais qu'un homme respecté par toute la Chine Tcheng-Daï, a été assassiné hier, lâchement, par les agents de nos ennemis. "

Et, pour une autre affiche que l'on devra coller A COTE :

"Honte à l'Angleterre, honte aux assassins de Schanghaï et de Canton!»

Tu mettras dans le coin de la seconde, en petits caractères : 20 mai-25 juin (l'histoire de Shanghaï et celle de Shameen). »

(Malraux, Les Conquérants, 114-115)

Par l'insertion de ces textes, le romancier montre implicitement comment fonctionnait le mécanisme de propagande et de contre-propagande à l'époque. Les rapports dialogiques complexes reflètent toute la machinerie et la finesse de la guerre idéologique. En effet le texte de la première affiche, proposée par Garine, ne mentionne pas le testament de Tcheng-Daï, mais l'affirmation que le leader chinois avait été assassiné, anéantit complètement la véracité de ce testament. L'autre affiche (qui devrait être mise exprès à coté) indique implicitement les exécuteurs de cet assassinat et renvoie à d'autres crimes commis par ces ennemis de la révolution. Cette complication des rapports dialogiques est très caractéristique des romans du $\mathrm{XX}^{\mathrm{e}}$ siècle où des liens sémantiques de caractères différents peuvent être établis entre plusieurs GD. 
Nous avons déjà cité un exemple tiré de La Nausée de Jean-Paul Sartre où les rapports dialogiques complexes se manifestent entre le dialogue des deux personnages au restaurant, le texte du menu, la commande et le monologue intérieur de l'un de ces personnages. Dans l'exemple d'André Malraux que nous venons de citer, nous trouvons aussi plusieurs GD qui entrent en dialogue : affiche des contre-révolutionnaires, testament de Tcheng-Daï, cité dans cette affiche, affiche du bureau de la propagande de Garine, qui parle de l'assassinat de Tcheng-Daï et autre affiche qui fait allusion aux exécuteurs de cet assassinat. Nous pouvons constater que ces deux derniers GD n'entrent pas en rapport d'opposition mais en rapport de complémentarité.

C'est un autre type de dialogisme qu'on peut aussi appeler synthétique car dans ce cas, un GD se complète de celui qui le suit. C'est un phénomène très répandu dans le texte du roman. Très souvent, les personnages ont recours dans un dialogue ou dans la conversation à la citation d'un GD second (ouvrage littéraire, historique, philosophique) ou d'un GD premier (la parole d'autrui) pour argumenter ou illustrer leur idée. Cela concerne aussi les GD introduits "par blocs» et consacrés au même problème comme, par exemple, les différentes notes dans les papiers de M. Thibault concernant la question de l'éducation des enfants, ou les lettres de ses pénitentiaires.

Un autre type du dialogisme, c'est les rapports synonymiques. Ce type de rapports est très proche de celui de synthèse mais a des nuances particulières, car il ne s'agit pas de complémentarité mais d'identité, et de la possibilité d'exprimer par des GD différents la même idée. Nous rencontrons ce cas intéressant chez Proust. Dans La Recherche l'écrivain a recours aux énoncés-types qu'on prononce à propos d'un malade incurable pour mieux exprimer l'état d'âme de Swann :

A partir de cette soirée, Swann comprit que le sentiment qu'Odette avait eu pour lui ne renaîtrait jamais, que ses espérances de bonheur ne se réaliserait plus. Et les jours où par hasard elle avait encore été gentille et tendre avec lui, si elle avait eu quelque attention, il notait ces signes apparents et menteurs d'un léger retour vers lui, avec cette sollicitude attendrie et sceptique, cette joie désespérée de ceux qui, soignant un ami arrivé aux derniers jours d'une maladie incurable, relatent comme des faits précieux :

«Hier, il a fait ses compte lui-même et c'est lui qui a relever une 
erreur d'addition que nous avions faite; il a mangé un œuf avec plaisir, s'il le digère bien on essaiera demain d'une côtelette », quoiqu'ils les sachent dénués de signification à la veille d'une mort inévitable.

(Proust, 347)

Ce rapport dialogique est très fin et pas très évident. Les énoncés concernant un malade ont plutôt une fonction métaphorique. Mais le mécanisme de la métaphore est construit lui aussi sur les rapports dialogiques par analogie. Par contre, ces énoncés, grâce à leur caractère stéréotypé et donc sémiotique, peuvent rimer avec les pensées intérieures du personnage et reproduire avec exactitude pour le lecteur le sentiment qu'éprouvait Swan.

\section{La stratification du texte et de la réalité romanesque}

La violation des lois du discours est aussi un des moyens que l'écrivain utilise pour produire un effet spécial sur le lecteur ${ }^{4}$. Dans ce cas-là, le romancier s'appuie sur la connaissance qu'a le lecteur des modèles discursifs ou des GD premiers (selon la terminologie de Bakhtine). Le rapport dialogique s'instaure dans ce cas-là entre la norme, l'image-modèle, présent dans la conscience du lecteur, et les violations produites.

Par exemple, dans L'Ecume des jours de Boris Vian, toute l'atmosphère d'absurdité est basée sur la violation de l'attente du lecteur. Nous avons déjà évoqué plusieurs fois la violation des lois du discours qui sert de fondement à l'esthétique de ce roman. Pour mieux expliquer le mécanisme de production de cet effet d'absurdité, voici la scène de la visite du médecin chez Chloé (pour faciliter l'explication nous avons numéroté tous les énoncés dans ce GD) :

(1)-Voulez-vous me suivre? proposa Colin

(2)-Je ne sais pas, dit le professeur, j'hésite...

Il se décida tout de même.

(3)-Qui est malade ?

(4)-Chloé, dit Colin.

(5)-Ah ! dit le professeur, ça me rappelle un air...

4 D'après le linguiste russe N. Roudiakov, la contradiction entre les événements de la réalité objective et leur représentation dans la fiction (notamment les transformations du fonctionnement des types de discours) constituent une partie importante du message de l'auteur adressé au lecteur). N.A. Roudiakov, Problemy stilistitcheskokgo analisa literatournogo proizvedenia, [Problèmes de l'analyse stylistique du texte artistique]. ADD, Voronej : VGU, 1978, p. 6. 
(6)-Oui, dit Colin, c'est celui-là.

(7)-Bon, conclut Mangemanche, allons-y. Vous auriez dû me le dire plus tôt. Qu'est-ce qu'elle a ?

(8)-Je ne sais pas, dit Colin.

(9)-Moi non plus, avoua le professeur, maintenant, je peux bien vous le dire.

(10)- Mais vous allez le savoir? demanda Colin inquiet.

(11)- Ca se peut, dit le professeur Mangemanche, dubitatif. Encore faudrait-il que je l'examinasse...

(12)- Mais venez donc..., dit Colin.

(13)- Mais oui... dit le professeur.

Colin le conduisit jusqu'à la porte de la chambre et se rappela brusquement de quelque chose.

(14)- Faites attention en entrant, dit-il, c'est rond.

(15)- Oui, j'ai l'habitude, dit Mangemanche, elle est enceinte?..

(16)- Mais non, dit Colin... vous êtes idiot... la chambre est ronde.

(17)- Toute ronde? demanda le professeur. Vous avez joué un disque d'Ellington, alors?

(18)- Oui, dit Colin.

(19)- J'en ai aussi chez moi, dit Mangemanche. Vous connaissez Slap Happy?

(20)- Je préfère...commença Colin, et il se rappela Chloé qui attendait, et poussa le professeur dans la chambre.

(21)- Bonjour, dit le professeur.

Il monta l'échelle.

(22)- Bonjour, répondit Chloé. Vous allez bien?

(23)- Mon Dieu, répondit le professeur, mon foie me fait souffrir par moments. Vous savez ce que c'est ?

(24)- Non, dit Chloé.

(25)- Bien entendu, répondit le professeur, vous n'avez certainement pas le foie malade.

Il s'approcha de Chloé et lui prit la main.

(26)- Un peu chaud, hein ?..

(27)- Je ne me rends pas compte. 
(28)- Oui, dit le professeur, mais c'est un tort.

Il s'assit sur le lit.

(29)- Je vais vous ausculter, si ça ne vous ennuie pas.

(30)- Je vous en prie, dit Chloé. [...]

(31)- Comptez, dit-il.

Chloé compta.

(32)- Ca ne va pas, dit le docteur, après vingt-six, c'est vingt-sept. (33)- Oui, dit Chloé. Excusez-moi.

(Vian, 90-91)

$\mathrm{Si}$, normalement, le médecin pendant la consultation doit toujours faire la preuve de sa compétence et de son intelligence, dans le dialogue cité, le professeur manifeste son incertitude et l'ignorance (énoncés 2, 9, 11). Il essaie tout le temps de glisser à un autre type de conversation, changer de sujet ${ }^{5}$, parler de musique et de ses préférences dans ce domaine, ce qui ne correspond pas du tout à son statut ni au but de sa visite. Il est assez bavard tandis que « la science médicale traite en effet la parole comme une fonction parasitaire, si elle véhicule autre chose pour des renseignements utiles pour le diagnostic, ou des ordres précis pour le traitement, elle ne peut être qu'un bavardage encombrant, une perte de temps, un commentaire superflu » (Baylon, Mignot, 1999, 346). C'est Colin qui tente tout le temps de faire revenir le professeur au sujet principal de sa visite. Dès le début de la consultation, nous observons aussi le changement des rôles médecin/malade : c'est le médecin qui se plaint de sa santé et non pas la malade (énoncé 23). La forme du GD est quand même conservée. On y retrouve les énoncés-types caractéristique de la consultation médicale, mais ou bien ils ont de fausses références, comme l'énoncé 15 (la question type quand on parle d'une malade «est-elle enceinte ? », posée par le professeur, concerne la chambre (!)) ou ils parodient ou imitent la forme et la structure des énoncés normaux (énoncé 31 : «comptez» au lieu de «respirez»etc.). Toutes ces violations produisent dans ce roman l'effet de l'absurdité dont nous avons parlé plusieurs fois. Pour que le lecteur reçoive ce message de l'écrivain, il faut qu'il ait une compétence discursive qui lui permette de sentir toutes ces

5 On peut même constater qu'il essaie de passer à un autre GD par l'énoncé 19. Colin est presque prêt à accepter, il commence à répondre dans le même genre (énoncé 20), mais se souvient de Chloé et se coupe la parole. Ici nous voyons bien comment fonctionne à travers l'énoncé le passage à un autre GD. 
inobservances des règles, de comprendre la signification qui naît du rapport norme/violation de norme et de l'apprécier.

Avec toute ces violations des GD un romancier peut aussi créer tout un univers à part, à l'intérieur même de son œuvre, comme par exemple Boris Vian dans le roman L'Ecume des jours crée à partir du langage deux mondes différents le monde faux sans amour et le seul monde vrai où l'amour règne.

\section{La conclusion.}

Comme cette petite étude a démontré, les romanciers français au XX-e siècle ont souvent recours aux différents genres du discours soit pour les utiliser dans la construction du texte littéraire soit pour véhiculer l'information implicite pour le lecteur en poussant ainsi le dernier vers la lecture plus active. Dans tous ces cas les auteurs exploitent souvent le caractère sémiotique du GD, leur intertextualité ou construisent les rapports dialogiques entre les GD ce qui serve à la production de la nouvelle signification.

\section{References:}

1. Adam, J.-M. Langue et littérature (Paris, Hachette 1991).

2. Adert, L. Les mots des autres (Paris, PUF, 1996).

3. Bakhtine, M. M. Esthétique de la création verbale (Paris, Gallimard, 1984).

4. Baylon, C., Mignot, X. La communication (Paris, Nathan, 1999).

5. Borgomano, M., Ravou Rallo, E. La littérature française du XX $X^{e}$ siècle. 1. Le roman et la nouvelle (Paris, Armand Colin, 1995).

6. Krysinski, W. Carrefours de signes : essais sur le roman moderne (The HagueParis-New York, Mouton, 1981).

7. Lepetyuk, I. «La présentation schématique du genre du discours.» Actes du colloque national des jeunes chercheurs (COLNAJEC) (Université Paul Valéry Montpellier III, 2000): 209-216.

8. Lotman, Y. La structure du texte artistique (Paris, Gallimard, 1973).

9. Rastier, F. «Le problème épistémologique du contexte et le statut de l'interprétation dans les sciences du langage.» Langage 129 (1998): 106-109.

10. Roudiakov, N. A. Problemy stilistitcheskokgo analisa literatournogo proizvedenia [Problèmes de l'analyse stylistique du texte artistique] (ADD, Voronej: VGU, 1978).

11. Todorov, T. Mikhaïl Bakhtine le principe dialogique (Paris, Seuil, 1981).

12. Vian, B. L'Ecume des jours (Paris, Union générale d'éditions, col. « 10/18 », 1974).

13. Camus, A. La Chute (Paris, Gallimard, 1968).

14. Malraux, A. Les Conquérant (Paris, Gallimard, (col.« Pléiade »), 1976).

15. Martin du Gard, R. Les Thibault, t. I (Paris, Gallimard, 1953).

16. Sartre, J.-P. La Nausée (Paris, Gallimard, 1938).

17. Proust, M. Du côté de chez Swann (Paris, Flammarion, 1988). 
УДК 811.124'373.46:61]-13

Стаття надійшла до редакиії 05.08.2018 Перевірено на плагіат 14.08.2018 p. унікальність $-95.34 \%$

\section{НОМІНАТИВНЕ ПОЛЕ СУБКОНЦЕПТУ SANITAS В ЛАТИНСЬКІЙ МОВІ}

\section{Милик Оксана Василівна, oxana.mylyk@ gmail.com}

канд.філол.наук, викладач кафедри латинської та іноземних мов, Львівський національний медичний університет імені Данила Галицького

Статтю присвячено дослідженню номінативного поля субконцепту SANITAS в латинській мові, яке має комплексний характер внаслідок інтеграції у його складі лексико-семантичного поля, лексико-фразеологічного поля та синонімічного ряду. Проаналізовано сутність номінативного поля субконцепту SANITAS у системі мови, визначено його ядро, приядерну зону, ближню й дальню периферії; досліджено засоби вербалізаиї мікрополів прядерної зони субконцепту SANITAS та список мовних одиниць, які вербалізують кониепт ЗДОРОВ'Я. Встановлено, що структура номінативного поля концепту ЗДОРОВ'Я складає ядерну та приядерну зони, щьо, в свою чергу, складаються з певних мікрополів, а також ближньої та дальньої периферій субконщептів SALUS, SANITAS, VALETUDO. Семантичне поле субкониепту SANITAS побудовано за принципом семантичної близькості / віддаленості від інтегральної семи та частоти набуття певних значень іменем конщепту. Визначено, що спільними для всіх трьох субконцептів SALUS, SANITAS, VALETUDO є слоти «наявність певного стану здоров'я (соматичного / психічного)» та «процес надання здоров'я (соматичного / психічного)». Наголошено, щуо субконщепт SANITAS найповніше інтегрував семи концепту ЗДОРОВ'Я та його вербалізатори є провідними у процесах позначення стану соматичного та психічного здоров'я в мовній картині світу давніх римлян. Стаття робить внесок у розвиток теоретичних засад дослідження концептів на матеріалі давніх мов, а також у розроблення теоретичних аспектів лінгвоконщептології, лінгвокультурології, лінгвоаксіології; надає підгрунтя для розуміння специфіки мислення $i$ пізнання, світогляду та особливостей інтерпретації світу, щзо були притаманні давнім римлянам.

Ключові слова: концепт, субоконцепт, SANITAS, здоров'я, номінативне поле.

Актуальні проблеми мовознавства [Актуальные проблемы языкознания] СМилик О. В. [Мылык О.В.], i.alekseeva@knu.ua Номінативне поле субконцепту SANITAS в латинській мові [Номинативное поле субконцепта SANITAS в латинском языке] (Українською / На укр. яз) 


\title{
НОМИНАТИВНОЕ ПОЛЕ СУБКОНЦЕПТА SANITAS В ЛАТИНСКОМ ЯЗЫКЕ
}

\author{
Мылык Оксана Васильевна, oxana.mylyk@gmail.com \\ канд.филол.н.,
} кафедра латинского и иностранных языков, Львовский национальный медицинский университет имени Данила Галицкого

Статья посвящена исследованию номинативного поля субконцепта SANITAS в латинском языке, который имеет комплексный характер вследствие интеграции в его структуре лексико-семантического поля, лексикофразеологического поля и синонимического ряда. Проанализирована сущность номинативного поля, показана его структура; определены его ядро, приядерная зона, ближняя и дальняя периферия; исследованы средства вербализации микрополей прядерной зоны субконщепта SANITAS и языковые единицы, вербализурующие кониепт ЗДОРОВЬЕ. Установлено, что структура номинативного поля концепта ЗДОРОВЬЕ выделяет ядерную и приядерную зоны, которые, в свою очередь, состоят из определенных микрополей, а также ближней и дальней периферий субконцептов SALUS, SANITAS, VALETUDO. Семантическое поле субкониепта SANITAS построено по приниипу семантической близости / удаленности от интегральной семы и частоты приобретения определенных значений именем конщепта. Определено, что общими для всех трех субконщептов SALUS, SANITAS, VALETUDO являются слоты «наличие определенного состояния здоровья (соматического / психического)» и «процесс восстановления здоровья (соматического / психического)». Отмечено, что субконщепт SANITAS полностью интегрировал семы концепта ЗДОРОВЬЕ и является доминирующим для обозначения состояния соматического и психического здоровья в языковой картине мира древних римлян, а лексема sanitas и однокоренные слова являются основными средствами вербализации конщепта ЗДОРОВЬЕ в латинском языке. Статья вносит вклад в развитие теоретических основ исследования концептов на материале древних языков, а также в разработку теоретических аспектов лингвоконцептологии, лингвокультурологии, лингвоаксиологии, что позволяет лучше понять специфику мышления и познания, мировоззрения и особенностей интерпретации мира через призму языкового сознания и ценностей древних римлян.

Ключевые слова: концепт, субконцепт, SANITAS, здоровье, номинативное поле.

Actual Problems of Linguistics [Aktual'ni problemy movoznavstva] (C) MylykO. [MylykO.V.], i.alekseeva@knu.ua Nominative Field of the Subconcept SANITAS in the Latin Language [Nominatyvne pole subkonceptu SANITAS v latyns'kij movi] (in Ukrainian) 


\title{
NOMINATIVE FIELD OF THE SUBCONCEPT SANITAS IN THE LATIN LANGUAGE
}

\author{
Mylyk Oksana Vasylivna, oxana.mylyk@gmail.com \\ $\mathrm{PhD}$, lecturer at theLatin and foreign languages department, \\ Danylo Halytskyy Lviv National Medical University
}

The article is devoted to the investigation of the nominative field of the subconcept SANITAS in the Latin language, which has a complex character due to the integration in its structure lexical field, phraseological field and synonymic sets. The essence of the nominative field in the system of language has been analyzed with regard to the specifics of nominative units - its verbalizers; kernel and prekernel zones, near and far peripheries have been defined; the means of microfields verbalization of the prekernel zone of subconcept SANITAS as well as the list of lingual units verbalizing the concept HEALTH have been investigated. It has been defined that nominative field structure of the HEALTH concept is represented as core and pre-core zones consisting of some microfields as well as close and distant peripheries of SALUS, SANITAS, VALETUDO subconcepts. The semantic field of the SANITAS subconcept has been built up due to the principle of semantic proximity / difference basing on the integral seme and frequency of acquiring certain meanings by the concepts' names. It has been defined that the SALUS, SANITAS, VALETUDO subconcepts share the common slots «being (somatically and/or mentally) healthy» and "providing somatic and/or mental health». It has also been emphasized that the SANITAS subconcept substantially integrated the semes of HEALTH concept that led to its dominant role in nominating both somatic and mental health states in the lingual world model of the ancient Romans, while the sanitas lexeme and co-root words appear to be the fundamental means that verbalize the HEALTH concept in the Latin language. Therefore, the article contributes to the development of the theoretical principles of ancient languages concepts' research as well as to the development of cognitive linguistics, linguistic culturology, axiological linguistics, etc. It enables to find out the specific dimensions of ancient Romans' mode of thinking and their world outlook.

Keywords: concept, subconcept, SANITAS, health, nominative field.

Вступ. Античну картину здорового існування окреслюють численні філософські погляди, в яких здоров'я визначалося найбільшою аксіологемою в системі цінностей античного світу. 
Античні філософи розрізняли здоров'я фізичне й душевне; здоров'я (фізичне й душевне) - найвище з усіх благ; благо, за Платоном, стоїть на вищому щаблі в ієрархії буття, воно $є$ станом й умовою досконалості буття, насолодою (кіренська школа, епікуреїзм), утриманням від пристрастей (кініки), чеснотою в сенсі панування вищої розумної природи над нижчою (стоїки), досконалістю особистості (за Аристотелем); античні філософи розглядали переважно внутрішній аспект «здоров'я» як злагоду тілесних і душевних проявів людини, як гармонію й пропорційність, оптимальне співвідношення тілесних i душевних складників; основними душевними якостями здорової людини є розсудливість і самовладання; життя згідно з природою, яке веде людину до доброчесності; щасливе життя полягає у володінні людиною здоровим глуздом, розсудливістю.

Аналіз останніх наукових публікацій $з$ теми дослідження. Одним із найважливіших процесів пізнавальної діяльності людини є концептуалізація, суть якої полягає в осмисленні інформації, що надходить до людини. Концептуалізація призводить до утворення концептів, концептуальних структур і всієї концептуальної системи в ментальності людини. В останні роки зріс інтерес до дослідження концепту як одиниці, яка забезпечує мовленнєво-розумову діяльність індивіда. Цій проблемі зокрема присвячені праціН. Д. Арутюнової, М. М. Болдирєва, С. Г. Воркачева, О.О.Залевської, В. І. Карасика, С. С. Нікітіної, Г. Г. Слишкіна, Ю. С. Степанова та інших дослідників. Науковці О. С. Васильєва та Ф. Р. Філатов, концепцію ЗДОРОВ'Я в античності називають «мозаїкою смислів і значень, які шикуються в складний і дивовижний семантичний візерунок навколо центрального поняття «здоров'я»: «гармонія» й «домірність», «краса» й «калокагатія», «злагода 3 власною природою» й «підпорядкування природі цілого», «розсудливість» і «самовладання», «осягнення Вищого Блага» й «набрання блага у власній душі»». Розсудливість, що грунтується на знанні того, в чому полягає «Вище Благо», і духовна свобода, незалежність від минущих зовнішніх благ, - становлять фундамент здоров'я, незворушності й стійкості духу [Васильева 2001, c. 25]. 
Вивчення концептосфери давніх римлян $є$ важливою ланкою у пізнанні їхнього світогляду, особливостей інтерпретації світу через призму мовної свідомості, духовних та матеріальних цінностей. Концепт ЗДОРОВ'Я відображає у свідомості стародавніх римлян не тільки знання про здоровий / нездоровий стан людини, але й експлікує вияв цінності людини в античному світі, ставлення людини до самої себе, ставлення держави до людини, систему вищих аксіологем людського буття. Саме це зумовлює актуальність публікації.

Об'єктом дослідження є субконцептSANITAS в латинській мові. Предмет дослідження - особливості вербалізації субконцепту SANITAS в латинській мові. Мета та завдання дослідження - виявити та описати сутність номінативного поля субконцепту SANITAS в латинській мові.

Одним із першочергових завдань у дослідженні певного концепту є одержання найбільш повного списку мовних одиниць, які вербалізують цей концепт [Богданова2009, с. 47]. Номінативне поле відрізняється від усіх інших структурних угрупувань лексики насамперед тим, що воно має комплексний характер, включаючи в свій склад групи таких типів: лексико-семантичне поле, лексикофразеологічне поле, синонімічний ряд тощо, але в той же час не виступає як структурне угрупування в системі мови, а являє собою виявлену і впорядковану сукупність номінативних одиниць [Попова 2007].

Номінативне поле концепту принципово неоднорідне: воно містить як прямі номінації безпосередньо самого концепту, що утворює ядро номінативного поля, так і номінації окремих когнітивних ознак концепту, що розкривають зміст концепту і відношення до нього в різних комунікативних ситуаціях, утворюючи периферію номінативного поля [Постовалова 2011, с. 66-67].

3. Попова та Й. Стернін наводять вичерпний перелік мовних засобів, які можуть входити в номінативне поле концепту та забезпечити його опис в процесі лінгвокогнітивного дослідження [Постовалова 2011]: прямі номінації концепту (ключове слово репрезентант концепту, яке обирається дослідником в якості імені концепту та імені номінативного поля, і його системні синоніми); 
похідні номінації концепту (переносні, похідні); спільнокореневі слова, одиниці різних частин мови, деривативно пов'язані з основними лексичними засобами вербалізації концепту; симіляри; контекстуальні синоніми; оказіональні індивідуально-авторські номінації; стійкі поєднання слів, синонімічні ключовому слову; фразеосполучення, які включають ім'я концепту; паремії (прислів'я, приказки та афоризми); метафоричні номінації; стійкі порівняння 3 ключовим словом; вільні словосполучення, які номінують певні ознаки, що характеризують концепт; асоціативне поле, отримане в результаті експерименту зі словом-стимулом, що іменує концепт; суб'єктивні словесні дефініції, запропоновані учасниками експерименту як тлумачення запропонованого їм концепту; словникові тлумачення мовних одиниць, що об'єктивують концепт; словникові статті в енциклопедіях або довідниках (інформаційно-експлікативні тексти); тематичні тексти (наукові або науково-популярні, що розповідають про зміст концепту); публіцистичні або художні тексти, які розкривають зміст концепту властивими ним засобами; сукупності текстів (за необхідності експлікації або обговорення змісту складних, абстрактних чи індивідуально-авторських концептів).

Ключове слово (лексична одиниця, яка найбільш повно номінує досліджуваний концепт) i його синоніми утворюють ядро номінативного поля. До ядра номінативного поля услід за Л. М. Михайловою, будемо відносити лексеми, які відзначаються: a) високою частотністю вживання; б) найбільшою узагальненістю за своєю семантикою у прямому значенні; в) стилістично та експресивно нейтральні [Попова 2007].

У структурі концепту $є$ ядро (когнітивно-пропозиційна структура концепту), приядерна зона (інші лексичні репрезентації концепту, його синоніми тощо) і периферія (асоціативно-образні репрезентації). Ядро і приядерна зона переважно репрезентують універсальні й загальнонаціональні знання, а периферія - індивідуальні [Маслова 2008].

У латинській мові існує кілька ключових лексем для номінації «здоров'я», які певною мірою відрізняються за значенням, точніше називаються різні його стани: salus, sanitas, valetudo, що відображає 
особливість уявлень давніх римлян про феномен «здоров'я». Саме тому вважаємо за доцільне розглядати інтегральну сему концепту ЗДОРОВ'Я у форматі трьох субконцептів: SALUS, SANITAS, VALETUDO. За визначенням I. В. Постовалової, саме субконцепти забезпечують множинне варіативне позначення головного концепту [Постовалова 2011, с. 35].

У даному дослідженні зупинимось детальніше на сутності субконцепту SANITAS та його засобах вербалізації.

Аналіз лексикографічного матеріалу, фрагментів оригінальних текстів, етимології та дериваційного поля лексем 3 історичною основою *salu-/salv-, *san-, *val- дав можливість зробити певні узагальнення. Історична основа *san-, за деякими припущеннями, сягає праіндоєвропейської основи *sŭa-/ sa: i.-є.*si-sə-mai «втішати, заспокоювати». Лексикографічні видання [Дворецкий 2008; Forcellini 1965; Glare 1968] дали змогу встановити лексико-семантичний діапазон слова SANITAS: «здоровий глузд, розсудливість, розумність», «тверезість, спокій, урівноваженість» (50\%), «здоров'я, здоровий стан» (40\%), «міцність, надійність, правильність» (10\%); прикметник sanus: «психічно / розумово здоровий» $(30,3 \%)$, «фізично здоровий» $(21,2 \%)$, «вільний від пристрастей, від афектів, розважливий» $(19,8 \%)$, «тямущий, солідний» $(9 \%)$, «цілющий» $(7,6 \%)$, «непошкоджений, у гарному стані» $(7,6 \%)$, «характерний для здорового стану» $(4,5 \%)$. Дериваційний аналіз дав можливість виявити, що більша частина дериватів має основне лексичне значення - «психічне здоров'я, психічний стан». Отже, субконцепт SANITAS є ментальною одиницею, яка відображає у свідомості давніх римлян уявлення про «психічне здоров'я», «нормальний психічний стан», «психічну урівноваженість, відповідність психічних реакцій обставинам i ситуаціям", «здатність до саморегуляції поведінки відповідно до соціальних норм та правил». Тож інтегрованою семою субконцепту

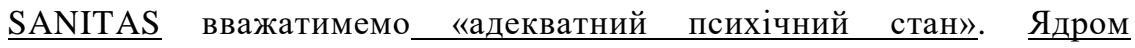
номінативного поля субконцепту SANITAS $є$ іменник sanitas «здоровий глузд, розсудливість, розумність», «тверезість, спокій, урівноваженість», прикметник sanus «психічно / розумово здоровий», «вільний від пристрастей, від афектів, розсудливий», прислівник sane 
«розумно, розсудливо, при здоровому глузді»; дієслово sanare «лікувати, зцілювати(душу), «напоумити когось, утішати».

У приядерній зоні субконцепту SANITAS можна виділити три мікрополя, які близькі до інтегрованої семи: 1) «брак різного роду афектів, адекватність поведінки»; 2) «душевне зцілення»; 3) «розсудливість, поміркованість, здоровий глузд».

Мікрополе «браку різного роду афектів, адекватної поведінки» поєднує слова, лексичне значення яких «стриманість, урівноваженість, поміркованість, самовладання»: tenere cupiditates suas (Cic. Verr. 2, 3, 3) - стримувати свої пристрасті; moderatio, onis, $\mathbf{f}$ - обмеження, самовладання, стриманість: moderatio cupiditatum (Cic. Fin. 2, 19), moderatio ardorum (Cic. N. D. 2, 92) - приборкання пристрастей; moderatio animi (Rhet. Her. 1, 1, 1) - стриманість, самовладання, урівноваженість; requies, etis, f - спочинок: requies animi (Tac. Ann. 2, 33, 3)-душевне задоволення; quies, etis, f - спокій, відпочинок: quies animi (Vell.2, 6, 2) - душевний спокій; modestia, ae, f - поміркованість, стриманість: modestia dolendi (Sen. Dial. 6, 2, 4) самовладання, приборкання пристрастей: modestia ac moderatio (Sen. Ep. 88, 30) - поміркованість і стриманість; temperantia, ae, f поміркованість, стриманість, самовладання; continentia, ae, f стриманість, самовладання; parsimonia, ae, $\mathbf{f}$ - стриманість, тверезість; sobrietas, atis, $\mathbf{f}$ - тверезість, стриманість, поміркованість.

Мікрополе «душевного зцілення" поєднує лексеми із семантикою «зцілення - позбавлення станів афекту, утішання, заспокоєння, полегшення страждань»: sanabilis, e - виліковний, цілющий: душевно/фізично, позбавлений афектних станів; cura doloris (Cic. Fam. 5, 16, 5) - утішання в скорботі; cura lacrimis (Prop.1, 3, 46) - заспокоєння від сліз; consolor, atus sum, ari - утішати, полегшувати, пом'якшувати; solor, atus sum, ari - утішати, заспокоювати; resedo, -, - , are - полегшити, зцілити; relevo, avi, atum, are - полегшити, заспокоїти, втішити; consolatio, onis, f - втішання, заспокоєння; consolamen, inis, n - утішання; paregoria, ae, f - заспокоєння, втішання, полегшення; mitigatio, onis, f - заспокоєння, втішання; sedamen, inis, n - заспокійливий засіб, утішання, заспокоєння; sedatio, 
onis, f,placatio, onis, $\mathbf{f}$ - заспокоєння; avocamentum, i, n - заспокоєння, утішання.

Мікрополе «розсудливості, поміркованості, здорового глузду»об'єднує лексеми із семантикою «розсудливості, поміркованості, розважливості, розумності, здорового глузду»: resanesco, sanui, -, ere - братися за розум, отямитися, mens, mentis, f розсудливість, поміркованість; mens animi (Lucr. 4, 757) розум;bonamens (Liv. 39, 16, 5) - здоровий глузд; sapiens, entis розумний, розважливий, розсудливий; sapientia, ae, f - розсудливість, здоровий глузд; sapienter - мудро, розсудливо; sapio, ii (ivi, ui), - , ere - бути розумним, розсудливим; ratio, onis, f - розум, здоровий глузд, розважливість: in gyrum rationis ducere (Cic. Off. 1, 26, 90) - напоумити; sensus, us, m - відчуття, сприйняття, свідомість, відчуття; розум, розсудливість: homo celer sensu (Vell. 2, 118, 2) - кмітлива людина; sensus communis (Hor. Serm. 1, 3, 63; Sen. Ben. 1, 12, 3) - здоровий глузд; imisensus(Hor. Epod. 14, 1) - глибина свідомості; animostare (Hor. Serm. 2, 3, 211) - зберігати здоровий глузд; resipisco, ivi (ii) / ui, -, ere знову прийти до тями, отямитися, схаменутися; adsanitatemreverti (Caes. D. G. 1, 42), adsanitatemredire (Cic. Fam. 12, 10, 1) - отямитися, схаменутися.

Ближня периферіяоб'єднує слова, лексичне значення яких «психічне здоров'я, брак афектів, адекватність поведінки, душевне зцілення, розсудливість, поміркованість, здоровий глузд» не $\epsilon$ головним, але умотивоване основним лексичним значенням (наприклад, пряме значення іменника cerebrum, i, n - мозок, оскільки мозок $є$ «осередком» розуму, це слово набуло цілком умотивованих значень «розум, розсудливість»): cerebrum, $\mathbf{i}, \mathbf{n}$ - головний мозок, розум, розсудливість; consilium, $\mathbf{i}, \mathbf{n}$ - розумність, розсудливість: simul consilium cum re amisisti? (Ter. Eu. 241) - невже разом з грішми ти втратив розум?; bono consilio facere (Pl. Aul. 476; Cic. Off. 1, 33, 120) - зробити при здоровому глузді; miscere stultitiam consiliis brevem (Hor. Carm. 4, 12, 125) - домішувати до розсудливості деяку частку глупоти; nullius consilii esse (Cic. Sest. 36) -бути безрозсудливим, некмітливим; intellectus, us, m - розуміння; розсудливість: intellectus animi (Quint. Inst. $10,1,14)$ - розсудливість; intellegentia, ae, f - розуміння; 
розсудливість: intellegentia communis (Cic. De or. 1, 249) - здоровий глузд; sinceritas, atis, f - збереженість, неушкодженість: sinceritas et animi et corporis (Val. Maх. 2, 6, 8) - здоров'я душі й тіла; confirmatio, onis, f - зміцнення, укріплення:confirmatio animi- душевне заспокоєння, утішання; mulceo, mulsi, mulsum, ere - заспокоювати, полегшувати: mulcere dolorem (Plin. Nat. 30, 58) - полегшувати біль, страждання; mitigo, avi, atum, are - полегшувати, приборкувати: mitigare odium precibus (Cic. Red. pop. 23) - приборкувати ненависть благаннями; mitigare dolorem (Cic. Fin. 2, 29, 95) - полегшувати страждання; mitigare animum (Tac. Hist. 1, 69, 28) - заспокоювати душу,mitigare iram (Ov. Trist. 4, 6, 13) - вгамовувати гнів; sublevo, avi, atum, are - послаблювати, полегшувати: sublevare metum (Tac. Ann. 14, 4, 4) - зменшити страх; potens sui (Hor. Carm. 3, 29, 41) - той, хто опановує себе; in potestate mentis esse (Cic. Tusc. 3, 5, 11) - володіти собою, бути при здоровому глуздi; sensus convaluere mеi (Ov. Trist. 1, 3, 13) - я оговтався; сотроs sui esse (Liv. 8, 18, 11) - бути при повній свідомості; аеqио апіто еsse (Cato Agr. 2, 5.) - байдуже, безпристрасно; medicabilis, e - виліковний (який лікує душевні хвороби, афекти); valetudo, inis, $\mathbf{f}$ - здоров'я: valetudo ei neque corporis nеque animi constitit (Suet. Calig. 50, 2) - y нього не збереглося ні тілесного, ні душевного здоров'я.

Дальня периферія об'єднує вербалізатори, які набувають у певному контексті значень «психічне здоров'я, брак афектів, адекватність поведінки, душевне зцілення, розсудливість, поміркованість, здоровий глузд», проте ці семи не умотивовані основним лексичним значенням слова: cor habere (Pl. Persa 623; Petr. 63, 8) - розумно, розсудливо; corde conspicere (Pl. Pseud. 767) розуміти; поnаbsone $(\mathrm{Gel} .15,25,1)$ - розумно, розсудливо; поп excidere sibi (Quint. Inst. 11, 2, 45.) - не втрачати контролю над собою; поп concuti (Sen. Ep. 71, 25) - залишатися незворушним; de lana sua cogitare (Ov. Ars 2, 683) - думати лише про свої справи, залишатися незворушним; nil admirari (Hor. Ep. 1, 6, 1) - нічим не вражатися, бути незворушним; tenere iram (Curt. 4, 2, 5.) - стримувати гнів; reprimere iracundiam (Ter. Ad. 794) - стримувати роздратування; tетреrare iras (Verg. A.1, 55) - стримувати гнів, temperare amori sиo (Petr. 83, 5) - 
вгамовувати свою пристрасть; allevare animum maerore (Curt. 4, 15, 11) - утімати душу від смутку; апітит recipere (Liv. 21, 58, 10) опритомніти, опанувати себе; expergefactum сариt erigere (Lucr. 5, 1204) - одуматися; vincere animos iramque (Ov. Ep. 3, 85) - приборкати свій запал і гнів; dum mетоr ipse mei, dum spiritus hos regit artus (Verg. А.4, 333) - поки я в повній свідомості, поки душа управляе иим (моїм) тілом; ех апіто scrupulum evellere (Cic. S. Rosc. 6) - утішати серие (душу); sermone recreare (Petr. 65, 6) - заспокоювати розмовою; judicium, i, n - розсудливість, розум, поміркованість: јиdicio facere (Cic. Fam. 10, 27, 2) - робити розсудливо; pectus, oris, n- серце, розум, розсудливість: toto pectore cogitare (Cic. Att. 13, 12, 4) - мислити розсудливо, de summo pectore dicere (Gell. 17, 13, 7) / hiscere (Apul. Fl. 9) - говорити необдумано; sal, salis, m - сіль, метафорично - розум: salem habere (Ter. Eu. 399) - бути розумним; иsurpatio bonae mentis (V.Mах. 4, 4) - володіння здоровим глуздом.

Висновки та перспективи подальших розвідок. Отже, аналіз лексикографічного матеріалу дав можливість зробити висновки, що субконцепт SANITAS є такою ментальною одиницею, яка відображала у свідомості давніх римлян уявлення про «психічне здоров'я», «адекватний психічний стан», «психічну урівноваженість, відповідність психічних реакцій до обставин і ситуацій», «здатність до саморегуляції поведінки згідно із соціальними нормами та правилами». Інтегральною семою субконцепту SANITAS $є$ «адекватний психічний стан». Ядром номінативного поля субконцепту SANITAS є іменник sanitas, прикметник sanus, прислівник sane, дієслово sanare. Приядерну зону утворюють мікрополя: 1) «брак різного роду афектів, адекватність поведінки»; 2) «душевне зцілення»; 3) «розсудливість, поміркованість, здоровий глузд».

\section{Література:}

1. Богданова, А. Г. «Когнитивная интерпретация единиц номинативного поляконцепта «вежливость» (на материале немецкого и русского языков).» Вестник Томского государственного университета 319 (2009): 11-15.

2. Васильева, О. С. Психология здоровья человека: эталоны, представления, установки: учебное пособие для студ. высш. учеб. заведений (Москва, Издательский центр «Академия», 2001), 352.

Актуальні проблеми мовознавства [Актуальные проблемы языкознания] СМилик О. В. [Мылык О. В.], i.alekseeva@knu.ua Номінативне поле субконцепту SANITAS в латинській мові [Номинативное поле субконцепта SANITAS в латинском языке] (Українською / На укр. яз) 
3. Дворецкий, И. Х. Латинско-русскийсловарь (Москва, Русский язык, 1976), 1088.

4. Маслова, В. А. Когнитивная лингвистика (Мн., Тетра Системс, 2008), 272.

5. Михайлова, Л. М. «Построение номинативного поля концепта «ГОВОРЕНИЕ» в современном английском языке.» Гуманитарные и социиальные науки 5 (2008), доступ hses-online.ru/2008/05/10_02_04/5_6.pdf.

6. Попова, 3. Д., Стернин, И. А. Когнитивная лингвистика (Москва, АСТ, Восток-Запад, 2007), 315.

7. Постовалова, І. В., Зана, Л. Ю. «Літературознавчий аналіз художнього твору: функціонування поняття “концепт”.» Вісник Луганського національного університету імені Тараса Шевченка, Серія Філологічні науки, ч. II, № 3 (214) (2011): 32-43.

8. Forcellini Ae. Lexicontotius Latinitatis, t. 1-4 (Forni, 1965).

9. Glare P. G. W. Oxford Latin Dictionary (Oxford, Oxford Universitypress, 1968), 2151.

\section{References:}

1. Bogdanova, A. G. «Kognitivnaja interpretacija edinic nominativnogo polja koncepta «vezhlivost'» (na material nemeckogo i russkogo jazykov) [Cognitive interpretation of units of the nominative field of the concept "politeness" (on the material of the German and Russian languages)].» Vestnik Tomskogo gosudarstvennogo universiteta 319 (2009): 11-15. (In Russ.).

2. Vasil'eva, O. S. Psihologija zdorov'ja cheloveka: jetalony, predstavlenija, ustanovki: ucheb. posobie [Psychology of human health: standards, ideas, attitudes] (Moskva, Izdatel'skij centr «Akademija», 2001), 352 (In Russ.).

3. Dvoreckij, I. H. Latinsko-russkijs lovar [Latin-Russian Dictionary] (Moskva, Russkij jazyk, 1976), 1088 (In Russ.).

4. Maslova V. A. Kognitivnaja lingvistika [Cognitive Linguistics] (Mn., Tetra Sistems, 2008.), 272 (In Russ.).

5. Mihajlova, L. M. «Postroenie nominativnogo polja koncepta «GOVORENIE» v sovremennom anglijskom jazyke [Construction of the nominative field of the concept "SPEAKING" in modern English].» Gumanitarnye i social'nye nauki 5 (2008), dostup // hses-online.ru/2008/05/10_02_04/5_6.pdf (In Russ.).

6. Popova, Z. D. Kognitivnaja lingvistika [Cognitive Linguistics] (Moskva, AST, Vostok-Zapad, 2007), 315 (In Russ.).

7. Postovalova, I. V. «Literaturoznavchij analiz hudozhn'ogo tvoru: funkcionuvannja ponjattja «concept» [Literary analysis of artistic work: the functioning of the notion "concept»].» Visnik Lugans'kogo nacional'nogo universitetu imeni Tarasa Shevchenka, Serija Filologichni nauki, ch. II, № 3 (214) (2011): 32-43 (In Ukr.).

8. Forcellini Ae. Lexicontotius Latinitatis, t. 1-4 (Forni, 1965).

9. Glare, P. G. W. Oxford Latin Dictionary (Oxford: Oxford Universitypress, 1968), 2151.

Actual Problems of Linguistics [Aktual'ni problemy movoznavstva] (C) Mylyk O. [Mylyk O.V.], i.alekseeva@knu.ua Nominative Field of the Subconcept SANITAS in the Latin Language [Nominatyvne pole subkonceptu SANITAS v latyns'kij movi] (in Ukrainian) 
УДК 811.111`42:82 - 1

Стаття надійила до редакиії 12.08.2018 Перевірено на плагіат 15.08.2018 p. унікальність $-96.3 \%$

\title{
ПОЕТИЧНИЙ ТЕКСТ ЯК СПЕЦИФІЧНИЙ ЗАСІБ ВІДТВОРЕННЯ ДІЙСНОСТІ
}

\author{
Москвичова Оксана Анатоліївна, oksana20121980@gmail.com \\ канд. філол. наук, доц. \\ Херсонський державний університет
}

Статтю присвячено дослідженню специифіки відтворення дійсності $y$ поетичній моделі світу, якою вона постає у британських поетичних текстах, шляхом лінгвопоетичного аналізу лексико-семантичних тропів як вербальних засобів актуалізачї когнітивних прочесів формування поетичної моделі світу, а також виявленню аксіологічно забарвлених глибинних смислів, специфічних для когнітивного стилю поезії британського романтизму, модернізму $i$ постмодернізму, иляхом лінгвокогнітивного $і$ поетико-когнітивного аналізу визначеної тропеїки. 3 позиції когнітивної лінгвістики та когнітивної поетики поетичний текст окреслюється у статті як втілення у поетичній творчості результату когнічії поета та його інтерпретації оточуючої дійсності крізь призму свого фізичного та соціально-культурного досвіду. Згідно з основними положеннями когнітивної лінгвістики, когнітивна поетика акцентує увагу дослідників поетичних текстів на метафоричності людського мислення, на його художності та образності, завдяки яким можлива концептуалізація дійсності людиною з опорою на ї̈ тілесний та сенсомоторний досвід. У реконструкиії поетичної моделі світу британських поетичних текстів звертаємось до сутності поезії та поетичного тексту, до специфіки відтворення дійсності у межах поетичного тексту, до естетичного аспекту поезї та до лінгвокомунікативних особливостей поетичного тексту. Стаття є актуальною y світлі тенденцій сучасних поліпарадигмальних досліджень, оскільки $\epsilon$ узагальненням $i$ систематизачією трьох лінгвістичних парадигм (лінгвопоетичної, лінгвокогнітивної $i$ поетико-когнітивної), спрямованих на побудову поетичної моделі світу як конструкту, у якому втілено глибинний смисл поетичних текстів у різні культурно-історичні періоди. Мета, завдання, результати й висновки статті обумовлені розкриттям специфіки поетичного світосприйняття, втіленої у поезї британського романтизму, модернізму $i$ постмодернізму. специфический способ отображения действительности] (Українською / На укр. яз) 
Ключові слова: картина світу, поетична модель світу, концептуальні тропи, лінгвокогнітивні механізми.

\section{ПОЭТИЧЕСКИЙ ТЕКСТ КАК СПЕЦИФИЧЕСКИЙ СПОСОБ ОТОБРАЖЕНИЯ ДЕЙСТВИТЕЛЬНОСТИ}

\section{Москвичёва Оксана Анатольевна, oksana20121980@gmail.com}

канд. филол. наук, доц.

Херсонский государственный университет

Статья посвящена исследованию специфики отображения действительности в поэтической модели мира в британских поэтических текстах при помощи лингво-поэтического анализа лексико-семантических тропов как вербальных актуализаторов когнитивных прочессов формирования поэтической модели мира, а также выявлению аксиологически маркированных глубоких смыслов, которые специифичныл когнитивному стилю поэзии британского романтизма, модернизма и постмодернизма при помощи лингвокогнитивного и поэтико-когнитивного анализа тропеики. Под углом зрения когнитивной лингвистики и когнитивной поэтики поэтический текст является воплощением в поэтическом творчестве результатов когниции поэта и интерпретации им окружающей действительности через призму его физического и сочиально-культурного опыта. Согласно основным положениям когнитивной лингвистики, когнитивная поэтика акцентирует внимание исследователей поэтических текстов на метафоричности человеческого мылиления, на его художественности и образности, благодаря которым возможна концептуализация действительности человеком с опорой на его телесный и сенсомоторный опыт. В прочессе реконструкции поэтической модели мира британских поэтических текстов обращаемся к сущности поэзии и поэтического текста, к специфике отображения действительности в рамках поэтического текста, $\kappa$ эстетическому аспекту поэзии $u$ лингвокоммуникативным особенностям поэтического текста. Статья актуальна в аспекте тенденций современных полипарадигмальных исследований, поскольку представляет собой обобщение и систематизацию трёх лингвистических парадигм (лингвопоэтической, лингвокогнитивной и поэтико-когнитивной), которые ориентированы на моделирование поэтической модели мира как конструкта, в котором воплощен глубокий смысл поэтических текстов в разные культурно-исторические периоды. Цель, задачи, результать и выводы статьи обусловлены раскрытием специифики поэтического восприятия мира, воплощенного в поэзии британского романтизма, модернизма и постмодернизма. 
Ключевые слова: картина мира, поэтическая модель мира, концептуальные тропь, лингвокогнитивные механизмы.

\title{
POETICAL TEXT AS THE SPECIFIC WAY OF THE REFLECTION OF REALITY
}

\author{
Moskvichova Oksana Anatolyevna, oksana20121980@gmail.com \\ $\mathrm{PhD}$, Assistant Professor \\ Kherson State University
}

The article is dedicated to the embodiment of reality in the poetic model of the world of the British poetry by means of the linguistic and poetic analysis of tropes as the way to actualize cognitive processes in the formation of the world model. By means of linguistic, poetic and cognitive analysis the cognitive aspect of the poetry of the British romantic, modern and post-modern periods is investigated. From the position of cognitive linguistics and cognitive poetics poetry is analyzed as the embodiment in the poetical works the result of cognition of a poet and his interpretation of reality on the background of his physical, social and cultural experience. Reconstruction of the poetical model of the world on the base of British poetical texts is accentuated on the notion of poetry and poetic texts, on the reflection of reality in poetry, on esthetic aspect of poetry and on linguistic and communicative peculiarities of poetry. The article is actual as the generalization of linguistic, poetic and cognitive paradigms aimed to the construction of the model of the world of different cultural and historic periods. The aim and the results of investigation are determined by the specification of the poetical viewpoint embodied in the British poetry of romantic, modern and post-modern periods.

Key words: world image, poetical model of the world, conceptual tropes, linguistic and cognitive mechanisms.

Вступ. Поезія освітлюється у лексикографічних джерелах як художньо-образна словесна творчість. Термін «поезія» пов'язаний із мистецтвом слова і фольклором та, у вужчому розумінні, представляє собою ритмічно організоване мовлення, сформоване на основі конкретноісторичної версифікаційної системи на відміну від прози [Гром'як 2007, c. 540-541]. Цим терміном позначають віршовані твори певного поета, нації чи епохи. У переносному значенні «поезія» означає чарівність, привабливість [Гром'як 2007, с. 540-541] і є синонімом до художньої літератури. Поетичний текст відтворює «іншу реальність» [Там само, c. 540-541], пов'язану 3 довколишнім світом багатьма асоціативними 
каналами. Оперта на ірраціональні принципи світобачення, поезія відмінна тим самим від логічних структур і відрізняється від прози з іiі виразним логічним компонентом, котрий посилює частку раціональних ознак у романі та повісті [Там само, с. 540-541].

Актуальність статті визначається іiі відповідністю загальному спрямуванню сучасної лінгвістики на вивчення зв'язку між мовою, мисленням i культурою, на розробку способів експлікації концептуального змісту поетичних текстів для реконструкції світобачення поетів шляхом конструювання і декодування поетичної моделі світу. Стаття $є$ актуальною у світлі тенденцій сучасних поліпарадигмальних досліджень, оскільки $\epsilon$ узагальненням i систематизацією трьох лінгвістичних парадигм (лінгвопоетичної, лінгвокогнітивної і поетико-когнітивної), спрямованих на побудову поетичної моделі світу як конструкту, в якому втілено глибинний смисл поетичних текстів у різні культурно-історичні періоди.

Об'єкт і предмет, мета і завдання дослідження.

Метою статті $\epsilon$ узагальнення теоретичних надбань вивчення поетичного тексту як специфічного засобу відтворення дійсності в аспекті когнітивної поетики.

Досягнення поставленої мети зумовлює розв'язання таких завдань:

- визначити особливості поетичного тексту як специфічного засобу відтворення дійсності і форми естетичної комунікації у лінгвопоетичних дослідженнях;

- встановити роль тропів при дослідженні поетичного тексту у лінгвопоетичному ракурсі;

- з'ясувати сутність потрактування поетичного тексту у контексті теорії когнітивної лінгвістики, зосередивши увагу на художній картині світу і моделі світу у поетичних творах.

Об'єктом дослідження постають лексико-семантичні тропи (епітет, метафора, образне порівняння, метонімія, оксюморон та метаморфоза) як вербальні засоби актуалізації когнітивних процесів формування поетичної моделі світу.

Предмет дослідження становить когнітивний потенціал тропів як вербальних засобів об'єктивації лінгвокогнітивних механізмів формування та декодування поетичної моделі світу, опредметненої у 
словесній тканині поетичних творів британського романтизму, модернізму і постмодернізму.

\section{Виклад основного матеріалу дослідження.}

У сучасній лінгвістиці традиційно існують чотири аспекти дослідження поетичного тексту, тобто його метрики, ритміки, рими, строфіки. Вказані аспекти вірша досліджено багатогранно, проте на окрему увагу заслуговує встановлення структурного зв'язку віршованого мовлення 3 явищами інших рівнів поетичного тексту (фонетикою, граматикою, стилістикою, семантикою). Вказані рівні дозволяють досліджувати поетичний текст у ракурсі його складових елементів, котрі мають свої певні закономірності і об’єднані у єдине ціле у межах поетичного тексту:

- звукова складова (фоніка й метрика поетичного тексту);

- словесна складова (граматика, морфологія, синтаксис вірша);

- стилістична складова (семантика, тропи, фігури у поетичному тексті);

- образна складова (словесні поетичні образи, мотиви, ідеї, емоції, вербально втілені у вірші);

- семіотична складова (знаки та символи, репрезентовані у лексичних одиницях поетичного тексту) [Лотман 1996, с. 23-25].

В аспекті лінгвопоетики дослідження поетичного тексту передбачає виявлення стилістичних прийомів та виразових засобів, котрі допомагають декодувати творчий задум поета, його естетичну інтенцію вплинути на читача. Лінгвопоетичний огляд вірша здійснюється на трьох рівнях, тобто семантичному (аналіз прямих значень лексичних одиниць поетичного тексту), метасеміотичному (аналіз додаткових (конотативних) значень лексичних одиниць вірша) i власне лінгвопоетичному рівні (аналіз естетичного потенціалу слів та їх ролі у створенні образності у поетичному тексті шляхом його наповнення стилістичними прийомами та виразовими засобами) [Бєлєхова 2004, c. 55-58].

Відтворення дійсності у поетичній творчості постає даниною історичним акцентам певної епохи, оскільки поет $є$ посередником між суспільством та його буттям або історією. Буття окремої особистості та цілого суспільства пов'язане з історичним часом, а поет як посередник 
між буттям та історією етносу є активним учасником відображеної ним у своїй поетичній творчості історичної дійсності. Уявлення людства та поета про історію, про час, про основні суспільно-історичні події епохи, про сутність культурно-історичних періодів можуть бути різними в залежності від епохи та лінгвокультурної спільноти, проте сутність тріади «Буття-Час-Людина» $\epsilon$ константною. У тріаді під ланкою «Людина» розуміємо не тільки творчу особистість поета, котрий відтворює історичну дійсність у своїй творчості, а й людину та суспільство окремої епохи, котрі читають поетичну спадщину певного поета. Історизм у поетичній творчості поета й образність віршованих текстів сприяють відтворенню основних історичних, культурних, суспільно-політичних подій у корпусі поезії епохи [Рашковский 2016, c. 25-26].

Естетичність поезії обумовлена іiі взаємодією з філософією у відображенні таких естетичних категорій, як: прекрасне, естетичне, піднесене, трагічне, комічне, потворне, тощо.

3 часів античності глибинна сутність поезії у відтворенні дійсності полягала у відтворенні навколишньої реальності шляхом словесної гармонії та ритму задля розкриття та розвитку мови. Антропоцентризм християнства сприяв наголошенню важливої ролі особистості поета у відтворенні ним реальності у власній поетичній творчості. Поет постає активним співучасником оточуючої його дійсності, іноді імпліцитним, котрий звертається до відомого або не відомого йому співрозмовника чи адресата 3 інтенцією привернути його увагу до тих проблем, котрі хвилюють поета. У такий спосіб проявляються лінгвокомунікативні особливості поетичного тексту, оскільки для поета віршований текст $\epsilon$ діалогом з читачем. У рамках комунікативної лінгвістики поезія ритмічно впорядкована словесна форма співбесіди поета з самим собою, а через себе - 3 іншими, тобто читачами або адресатами. Поезія монодіалог і внутрішньо напружена комунікація, втілена в образній поетичній творчості [Левин 1977, с. 8].

Інтеграція потрактувань поетичного тексту у його здатності відображати навколишню дійсність дозволяє розуміти його як самостійну єдність і певним чином організовану семіотичну структуру, котра підпорядковується правилам мови носіїв окремої лінгвокультурної 
спільноти [Лотман 1996, с. 66-67]. Значна роль поетичного тексту у віддзеркаленні дійсності обумовлена тим, що вірш $\epsilon$ потужним механізмом для пошуку істини поетом, засобом для культурної комунікації між носіями мови та пізнання ними реальності завдяки тому, що поетичний світ корелюється з моделлю реального світу [Там само, c. 100-102].

Відтворенню дійсності у поетичному тексті сприяє його образність, котра створюється поетом шляхом використання стилістичних прийомів та фігур, зокрема тропів. Тропи - лексичні виразові засоби, в яких одне слово або словосполучення вживається у зміненому значенні (метафора, гіпербола, літота, метонімія, синекдоха, антономазія, іронія, персоніфікація, алегорія, перифраз, епітет, оксиморон, метаморфоза) [Арнольд 2005, 123-125; Москвичова 2015, 190].

Тропи - не лише образна сітка, крізь яку сприймається світ, а й певне суб'єктивне відношення до реальності, котре обумовлює характер світобачення та відчуття дійсності. Тропи (порівняння, метафори, метонімії) як виражально-зображувальні засоби $є$ двоаспектними, оскільки вони виражають денотативний зміст, формують його сутність та оцінку і суб'єктивне відношення. В основі тропів - операції трансформації, тотожності, суміжності, контрасту. Завдяки цим операціям лексичні компоненти тропів стають образними структурами задля створення ефекту переконання, емоційної реакції, доказовості [Арнольд 2005, с. 130-131; Москвичова 2015, с. 178].

Завдяки образності, втіленої у поетичному тексті за допомогою тропів, читач має змогу уявляти предмети навколишньої дійсності і осягнути сутність свого буття. У стилістичному аспекті тропи постають взаємодією значень слів при створенні художніх образів. Образ $є$ основним засобом художнього узагальнення дійсності, знаком об'єктивного корелята людських переживань та особливою формою суспільної свідомості, а також відображенням зовнішнього світу у свідомості людини. Художній образ як одна 3 форм віддзеркалення реальної дійсності надає можливості людині по-новому сприймати світ і передавати своє власне ставлення до нього. Образ - модель дійсності, котра відновлює інформацію, отриману людиною 3 навколишньої 
дійсності, у новій сутності у процесі практичного пізнання особистістю реальності. Образ не тільки віддзеркалює навколишній світ, а й матеріалізується у тексті, відокремлюється від творця і стає фактом дійсності. Образи сприяють виникненню можливості передати читачу особливе бачення світу поетом або автором і виражені в тексті метафорою, метонімією, синекдохою та іншим інвентарем тропів [Бєлєхова 2004, с. 70-73]. Читач, спираючись на власний естетичний та соціальний досвід, інтерпретує інформативність образів окремої епохи.

Провідна роль поетичних текстів у відображенні дійсності обгрунтовується культурою певної нації і зверненням поетів до одвічних проблем буття людини, життя та смерті. На відміну від філософії та прози, поетичні тексти буяють образністю, втіленою у словесних поетичних образах. Містичність й тайна поетичного слова обумовлена здатністю поетів впливати на людські душі, підбадьорювати, змусити співпереживати читача вірша разом 3 поетом, осягнути власну сутність $\mathrm{i}$ своє місце у Всесвіті. Поезія у будь-який культурно-історичний період була й залишиться реакцією поета на негаразди суспільства, війни, політичні події. Водночас, поезія постає рефлексією особистісних і душевних страждань і переживань самого поета, його духовною сповіддю перед читачем.

Саме тому, поетичний текст $є$ антропоцентричним, оскільки відображає власне судження поета, його життя. Віддзеркалення дійсності у поезії тісно пов'язане з мовою певної лінгвокультурної спільноти або нації, тому що у поетичному мисленні відбиття реальності долає шлях від мислення поета до вираження ним свого світогляду словесно і реалізації його поетичної позиції у поетичному тексті за допомогою лексичних одиниць й прикрашення його словесними поетичними образами [Левин 1977, с. 10]. Схематично цей процес $\epsilon$ таким:

$$
\text { мислення поета } \rightarrow \text { мова } \rightarrow \text { поезія }
$$

Становлення образності поетичного тексту та іï ролі у відображенні реальності в ньому обумовлено еволюцією образу від архаїчного періоду до сьогодення [Бєлєхова 2004, с. 160]. Так, в архаїчний період здатність людей співвідносити предмети та явища навколишньої дійсності сприяла виникненню образного мислення і образ поставав формою мислення людини та засобом пізнання. Перенесення 
уявлення людства про навколишню дійсність в архаїчні міфологічні та фольклорні джерела обумовлене законами природи й сприяло естетичному освоєнню світу людиною. Відображення дійсності у вказаний період характеризується єдністю суспільства i природи, соціальних та природних явищ [Бєлєхова 2004, с. 156]. Хоча, архаїчний період не ознаменовано зафіксованими літературними поетичними пам'ятками, проте, у магічних заклинаннях та ритуалах прослідковується виникнення метафор та метаморфоз [Бєлєхова 2004, с. 81-82; Москвичова 2015, c. 5-10].

3 часів античності філософи, представники Олександрійської школи, висловлювали свої судження у формі поетичних творів (Арат, Тіт Лукрецій Кар) [Гром'як 2007, с. 540-541]. У зазначений період поезія подолала шлях свого становлення від міфології до духовної лірики й ораторської прози (Демосфен), філософської прози (Платон і Аристотель) й історичної прози (Плутарх, Тацит) [Гром'як 2007, с. 540-541]. На важливу роль поезії у відображенні реального та уявного світів указував Аристотель і зазначав, що поезія більш багата на філософський смисл, ніж історія [Гром'як 2007, с. 540-541]. Поетична спадщина Античності свідчить про наявність естетичного та філософського сприйняття дійсності античними поетами, а тексти збагачуються метафорами, метоніміями, паралелізмом та метаморфозою [Бєлєхова 2004, с. 90-91; Москвичова 2015, с. 150].

У середньовічній поезії формується художня ідея, новий тип художнього образу, націленого на відтворення ідеалів та догм епохи. На відміну від образів Античності, котрі відтворювали дійсність у поезії за принципами краси, мрії та гармонії, середньовічна образність збагачується архетипами, спрямованими на розкриття та осягнення сутності християнства. Поетична творчість Середньовіччя відрізняється від Античності фантазією, багатою поетичною уявою, котрі здатні вплинути на людину та очистити ii думки та почуття. У період Античності відображення дійсності у поезії фокусувалось навколо питань життя та смерті, стосунків людини з природою, основних моральних догм того часу. У Середньовіччі поетична увага у відображенні дійсності зосередилась на проблематиці душі людини, iii внутрішнього світу, потойбічного життя, нагороди або покарання за праведну чи грішну 
поведінку. Стереотипи поетичного мислення зазнали впливу усталених християнських символів, котрі уможливлювали осягнення поетом взаємозв’язку між сакральним та профанним, між небом і землею, між людиною та богом [Бєлєхова 2004, с. 112; Москвичова 2015, с. 20].

Спільність між філософією та поетичною творчістю набуває чіткого окреслення в епоху Відродження, оскільки люди почали звертати увагу на свою сутність, пізнавати реальність та буття, шукати відповіді на одвічні філософськи питання стосовно сутності життя та смерті, зокрема й у поетичних текстах того часу та витворах мистецтва. У подальшому, в епоху Відродження, Нового часу, романтизму, модернізму та постмодернізму, символічна уява стала одним із видів поетичного мислення і символізм виокремився як спосіб художнього відображення життя у семантиці не лише поетичного, а й художнього тексту, збагативши їх не лише символами, а і симулякрами [Бєлєхова 2004, c. 144; Москвичова 2015, с. 112] ('симулякр' - маскування відображеної реальності, гіперреальність [Гром'як 2007, с. 256-257]). Від Середньовіччя до сьогодення образність поетичного тексту та відображення дійсності у віршах шляхом словесних поетичних образів характеризується поступовою еволюцією від метафори до символу, від символу-алегорії до метонімії, від метонімії до знаку [Бєлєхова 2004, с. 25; Москвичова 2015, с. 174].

Розвиток британської поетичної уяви зумовлений культурноісторичними подіями епох, котрі сприяли трансформації тропів, i, відповідно, вплинули на образність у поетичних текстах як засобі відображення дійсності. Так, англійський романтизм (друга половина XVIII століття - XIX століття) не є тільки літературною або поетичною течією, а й характеризується універсальним поглядом на світ шляхом всебічного осягнення дійсності і узагальнення знань людства. Романтизм 3'явився у період розчарування та відчаю європейського суспільства, у час віри у нові ідеали після французької революції. Епоха характеризується розчаруванням митців у місії людства на тлі руйнування історичних ідеалів епохи. Романтизм постав новою музою помсти та туги, прокляття та відчаю. Зазначена культурно-історична епоха відзначається естетичним ракурсом сприйняття реальності. Англійський романтичний поет - мислитель, який творить на межі 
протиріч між ідеалом та історією. Крах своїх переконань поет-романтик порівнює 3 вічністю, 3 античною давниною, ідеальною та істинною реальністю. Британські поетичні тексти романтизму надзвичайно образні та символічні, рясніють метафорами, метаморфозами, метоніміями, оксиморонами, порівняннями [Бєлєхова 2004, с. 166; Москвичова 2015, c. 168].

Модерністська британська поетична традиція (кінець XIX початок XX століття) прагнула пізнати сутність буття людини, реалістично відобразити дійсність, привернути увагу суспільства до проблем сучасності. Епоха характеризується експериментами у поетичній творчості, відхиленням від мовних норм та ритмічних віршованих канонів. У такий спосіб британські поети привертали увагу читачів до невпорядкованості у світі, парадоксу реальності, нестабільності мови у відображенні буття. Британські поетичні тексти вийшли за межі поетичної творчості і наблизились до сфер живопису, графіки, музики шляхом графічності та фонетичності. У британській модерністській поезії акцентується увага на картині світу поета та на його авторській стилістиці, інтертекстуальності, архетипності. У британській поезії модернізму розширюються значення слів, збагачується полісемантичність англійського лексикону. Віршовані тексти буяють тропеїкою, наповненою знаками, символами, симулякрами. Набуває змін діада «мова - поезія», оскільки поетична мова збагачує певну мову у формі додаткового мовного пласту завдяки образності стилістичних виразових засобів. Багатий інвентар тропів сприяє фундаменталізації картини світу поета та епохи за допомогою різних мовних субстратів, котрі описують реальність як ієрархічну систему [Бєлєхова 2004, с. 164; Москвичова 2015, с. 180].

Британський постмодернізм (друга половина XX століття теперішній час) характеризується агностицизмом (неспроможністю об'єктивного пізнання дійсності та іiі закономірностей), естетичним плюралізмом, відмовою від дидактичності текстів, кодуванням текстів, усуненням авторського «я», інтертекстуальністю, іронією, епатажністю. Елімінується опозиція між мовою та світом, між конкретним та абстрактним, між живим та неживим, між сакральним та профанним, між високим та низьким; між минулим, теперішнім і майбутнім, між часом та специфический способ отображения действительности] (Українською / На укр. яз) 
простором, між культурою та природою, між реальним та уявним, між мистецтвом і не мистецтвом. Британський поетичний текст окреслюється маргінальністю поета (відчуженням від соціуму), його прагненням відродити еталонність мови, відродити пї цінності у протиставленні до британської культури. Увагу читача зосереджено у поетичному тексті на трансформаціях, процесах становлення особистості. Британська постмодерністська поезія виходить за межі етики, естетики та граматики i зорієнтована на вираженні філософських поглядів поета. Важливими конструктивними елементами постмодерністського британського поетичного тексту постають іронія, самоіронія, мовна гра [Бєлєхова 2004, с. 166; Москвичова 2015, с. 184].

\section{Висновки та перспективи подальших розвідок.}

Висновуємо, що поетичний текст як специфічний засіб відтворення дійсності характеризується своєю комплетивністю ('комплетивність' лінгвістична функція, пов'язана 3 процесами неологізації, метафоричної номінації, зі сферою поетичної фразеології). Поезія постає процесом і результатом творчої діяльності поета, спричиненої мовними, естетичними та соціальними факторами. Від архаїчної епохи до сучасності головну роль у відображенні дійсності у літературних та поетичних пам'ятках відігравала образність, втілена у художніх та поетичних текстах за допомогою тропів. Виникнувши у стародавній культурно-історичний період, тропи поступово укорінились у творчості поетів різних культурно-історичних періодів, зокрема й у британській поезії. Тропеїчність сприяє лінгво-стилістичному втіленню естетичності поетичних текстів та реалізації у віршах основних філософських естетичних категорій та естетичної функції.

Перспектива подальших досліджень обумовлена вивченням специфіки відтворення дійсності у поетичній моделі світу, шляхом лінгвопоетичного аналізу лексико-семантичних тропів як вербальних засобів актуалізації когнітивних процесів формування поетичної моделі світу, а також виявленню аксіологічно забарвлених глибинних смислів, специфічних для когнітивного стилю поетів британського романтизму, модернізму і постмодернізму, шляхом лінгвокогнітивного та поетикокогнітивного аналізу визначеної тропеїки, що передбачає застосування когнітивно-дискурсивних стратегій інтерпретації смислу поетичної 
моделі світу, а саме: реконструкцію аксіологічно навантажених художніх концептів як складників поетичної моделі світу, моделювання концептуальних тропів як когнітивного підгрунтя формування поетичної моделі світу та конструювання концептуальних блендів як емергентних когнітивних структур втіленого розуміння у поетиці британського романтизму, модернізму і постмодернізму.

\section{Література}

1. Арнольд, И. В. Стилистка. Современный английский язик (Москва, Флинта, Наука, 2005): 89-127.

2. Бєлєхова, Л. І. Словесний образ в американській поезії: лінгвокогнітивний аспект (Москва, ООО “Звездопад”, 2004), 376.

3. Левин, Ю. И. «Лирика с коммуникативной точки зрения.» Избранныетрудыл: Поэтика. Семиотика (The Hague - Paris, Structure of texts and Semiotics of Culture, 1977), 14.

4. Літературознавчий словник-довідник, за ред. Р. Т. Гром'яка, Ю. І. Коваліва, В. І. Теремка (Київ, ВЦ «Академія», 2007), 752.

5. Лотман, Ю. М. Внутри мыслящих миров. Человек - текст - семиосфера история (Москва, Языки русской культуры, 1996): 23-114.

6. Москвичова, О. А. «Еволюція метаморфози в англійському поетичному мисленні.» Монографія (Херсон, Айлант, 2015), 220.

7. Рашковский, Е. Философия поэзии, поэзия философии (СанктПетербург,Алтейя, 2016): 5-34.

\section{References:}

1. Arnold, I. Stylistics. The Modern English Language (Moskva, Flinta. Nauka, 2005):89-127 (inRuss).

2. Belekhova, L. Word image in the American Poetry: Linguistic and Cognitive aspects (Moskva, Zvezdopad, 2004), 376 (inUkr.).

3. Levin, Y. Poetry from the Communicative Viewpoint (The Hague-Paris, Structure of Texts and Semiotics of Culture, 1977), 14 (inRuss.).

4. Gromyak, R. Literary Dictionary (Kyyv, Akademia, 2007), 752 (inUkr.).

5. Lotman, Y. In the Intraworlds. A human - a text - a semioticsphere - history (Moskva,Yaziki russkoj kultury, 1996): 23-114 (inRuss.).

6. Moskvichova, O. Evolution of Metamorphosis in the English Poetry (Kherson, Aylant, 2015), 220 (inUkr.).

7. Rashkovskiy, E. Philosophy of Poetry, Poetry of Philosophy (Sankt-Peterburg, Alteya, 2016): 5-34 (in Russ.). 


\title{
ФУНКЦІОНУВАННЯ АЛЮЗІЙНИХ ІМЕН В ХУДОЖНЬОМУ ТЕКСТІ
}

\author{
Трищенко Ірина В'ячеславівна, itryshchenko@ hotmail.com \\ канд. філол. наук, доц. \\ Київський національний університет імені Тараса Шевченка \\ Інститут філології
}

Стаття присвячена дослідженню специфіки функиіонування алюзійних імен в художньому тексті в позиції звертання. Вони розглядаються в рамках прийому метафоричної антономазіі та трактуються як випадки актуалізаиії алюзї в художньому тексті. Алюзійні імена поділяються на імена реальних особистостей та імена літературних, біблійних персонажів. Вони також аналізуються як засоби вторинної номіначії адресата. Цей прочес відбувається на основі вибору спільної семантичної ознаки для суб'єктів первинної та вторинної номінації. Вказані імена розрізняються також за ступенем відомості їхніх денотатів для читачів. Окрім іменсимволів досліджуються алюзійні імена, які утворюються на основі вторинної оказіональної номінації. Вибір певної спільної семи та нейтралізачія різних опозицій додають їм експресивності. Визначається роль контексту при актуалізаиії алюзійних імен та наводяться приклади набуття ними як позитивних, так інегативних конотаиій в залежності від контексту. Окрім иього розглядаються варіанти експлікаиії мотивациї вибору тієї чи іншої ознаки для перейменування, а саме в прямій мові або репліках персонажів (як мовия, так і адресата), в авторському тексті та ремарках.

Ключові слова: художній текст, антономазія, алюзія, звертання, вторинна номінація, мотиваиія вибору семантичної ознаки.

\section{ФУНКЦИОНИРОВАНИЕ АЛЛЮЗИВНЫХ ИМЕН В ХУДОЖЕСТВЕННОМ ТЕКСТЕ}

\author{
Трищенко Ирина Вячеславовна, itryshchenko@hotmail.com \\ канд. филол. наук, доц. \\ Киевский национальный университет имени Тараса Шевченко \\ Институт филологии
}

Статья посвящена исследованию специифики функционирования аллюзивных имен в художественном тексте в позииии обращения. Они рассматриваются в рамках приема метафорической антономасии и трактуются как случаи 
актуализации аллюзии в литературном дискурсе. Аллюзивные имена подразделяются на имена реальных личностей и литературных, библейских персонажей. Они также анализируются как средства вторичной номинации адресата. Этот процесс происходит на основе общего семантического признака субъектов первичной и вторичной номинации. Указанные имена различаются также по степени известности их денотатов читателям. Помимо символических имен исследуются аллюзивные имена, которые создаются на основе вторичной окказиональной номинации. Выбор определенного общего семантического признака и нейтрализачия различных оппозиций добавляет экспрессивности этим именам. Определяется роль контекста при актуализации таких имен и приводятся примерь приобретения ими как положительных, так и отрицательных коннотаций в зависимости от контекста. В статье также выделяются и характеризуются видь мотивации употребления вторичных номинаций-обращений: объективная, субъективная и речевая. Кроме этого, рассматриваются варианты экспликации мотивированности выбора того или иного признака для переименования, а именно в прямой речи или репликах персонажей (как говорящуего, так и адресата), в авторском тексте и ремарках.

Ключевые слова: художественный текст, антономазия, аллюзия, обращение, вторичная номиначия, мотивачия выбора семантического признака.

\title{
FUNCTIONING OF ALLUSIVE NAMES IN LITERARY DISCOURSE
}

\author{
Tryshchenko Iryna, itryshchenko@ hotmail.com \\ $\mathrm{PhD}$ in Philology, Associate-Professor \\ Taras Shevchenko National University of Kyiv \\ Institute of Philology
}

This paper is devoted to the study of specifics of allusive names functioning in literary discourse. They are considered within the framework of metaphoric antonomasia and are treated as cases of allusion actualization in literary discourse. Allusive names are subdivided into names of real persons and names of literary, biblical characters. They are analyzed as means of secondary nomination of the addressee. This process takes place on the basis of common semantic feature of subjects of primary and secondary nomination. The semantic feature that is in the focus of metaphoric antonomasia may take both central and peripheral place in the semantic structure of original name. The given names are also distinguished according to the familiarity of their denotata to the readers. Many names have become symbols of certain human qualities. The denotata of such names are models of a certain kind, i.e. they impersonate the highest degree of some quality. In their 
figurative use the weakening in quality intensity is observed for the occasional referent. Besides symbolic names, allusive names based on secondary occasional nomination are studied. The choice of certain common semantic features and neutralization of different oppositions add expressivity to such names. The role of context during the actualization of such names is established, and examples of acquiring by them positive or negative connotations are discussed. Types of motivation of secondary nominations usage as address forms are revealed and characterized in this paper: objective, subjective and speech ones. Besides that, variants of explication of motivation for the choice of this or that semantic feature for renaming are defined. They include direct speech or remarks of the characters (both the speaker and addressee), author's text or remarks.

Key words: literary discourse, antonomasia, allusion, form of address, secondary nomination, motivation for the choice of semantic feature.

Дослідження експресивних засобів художнього тексту, на наш погляд, завжди залишається актуальним. Літературний процес безперервно триває. 3'являються нові художні твори і нові жанри. Їх автори вдаються до різних експериментів та демонструють нові креативні техніки письма для зацікавлення читачів та вираження в образній формі наболілих проблем людства. Для кращого розуміння авторського задуму потрібен об'єктивний науковий аналіз. Серед указаних експресивних засобів нашу увагу привернули звертання. Дані складні номінативні одиниці розглядалися, як правило, в структурно-семантичному (Ю. Д. Апресян, О. Г. Ветрова, В. Є. Гольдин, М. А. Олікова, Дж. Лич, М. Шорт), прагматичному (Н. Д. Арутюнова, М. М. Бахтін, Г. Г. Почепцов, М. Л. Прет, С. К. Левінсон)та соціолінгвістичному аспектах (Р. Браун, М. Форд, А. М. Монтгомері, С. М.Ервін-Тріп). Але їх стилістичні особливості та експресивний потенціал не знайшли ще достатньо повного відображення в науковій літературі. Ось чому об'єктом нашого дослідження виступає система експресивних засобів художнього тексту, а ії предметом - особливості звертань як складових вказаної системи. Метою даної розвідки є дослідження специфіки функціонування антономазій-звертань в художньому тексті на матеріалі творів сучасних англомовних авторів.

У статті стверджується, що метафорична антономазія є одним із випадків актуалізації алюзії в літературному дискурсі. Ми також спробуємо продемонструвати, що метафорично вживані власні імена належать до категорії посилань, тобто до одного із двох головних маркерів алюзії [Реrri 1978, p. 289-307]. 
Алюзійні власні імена (антропоніми) можна розділити на дві групи: імена реальних особистостей (письменників, акторів, політичних діячів) та імена літературних та/або біблійних персонажів. Метафоричний перенос $\epsilon$ типовим для таких імен. Проаналізуємо декілька прикладів із художніх творів, в яких імена реальних особистостей та літературних персонажів використовуються як засоби вторинної номінації адресата [Телия 1977, с. 191210]. Таке вживання базується на певних спільних рисах ситуативного адресата та реального носія даного імені.

(1) ... But Sarah stood aside and indicated the gasping, throat-clutching Mrs. Poulteney, which gave Mrs. Fairley her chance to come to her aid. "You wicked Jezebel - you have murdered her!'”[Fowles 1980, p. 212]

(2) 'Never mention a lady's name in connection with a scandal, Sherlock. Shame on you. '[Bellem 1978, p. 167]

(3) Tom: I'm going out on the terrace.

Jim (goes after him): You know, Shakespeare - I'm going to sell you a bill of goods! [Bellem 1978, p. 176]

У першому прикладі один з персонажів алюзійно вживає біблійне ім'я, звертаючись до іншого персонажа. В другому прикладі ім'я Шерлока Холмса лунає при звертанні до звичайного приватного детектива. В третьому прикладі мовець використовує ім'я Шекспіра у розмові зі своїм другом, який пробує займатися письменництвом.

Таким чином при метафоричній антономазії перенос імені з об’єкта первинної номінації на об'єкт вторинної номінації відбувається на основі певної спільної семантичної ознаки. Але цей процес супроводжується порушеннями обмежень сполучуваності, тобто нейтралізацією різних опозицій.

Семантична ознака, яка потрапляє у фокус метафоричної антономазії, може займати як центральне, так і другорядне місце в семантичній структурі вихідного імені. Отже вищезгадані семантичні ознаки (семи) можуть нейтралізуватись у межах вказаних опозицій.

Вважаємо за доцільне зауважити, що алюзійні власні імена розрізняються також за ступенем відомості їхніх денотатів. Багато імен стали символами певних людських якостей. Так, Отелло символізує ревнощі, Даліла - підступність, сер Галахад - благородство. Таким чином, денотати цих імен є еталонами певного роду, тобто вони представляють найвищу міру якості. 
Але у випадках їх образного вживання спостерігається послаблення інтенсивності певної якості для оказіонального референта.

Проте існують алюзійні імена, які вживаються не так часто як символічні. Для них вторинна номінація має оказіональний характер [Азнаурова 1977, с. 89-90]. Якщо процес переходу власних імен у звичайні представити у вигляді шкали, то символічні імена розташувалися б ближче до ії кінця (повний перехід до звичайних імен), ніж оказіональні алюзійні імена.

Вибір певних спільних семантичних ознак і нейтралізація різних опозицій безперечно додають експресивності як алюзійним іменам, так і всій оповіді загалом. Хотілося проілюструвати попередні твердження деякими прикладами з художньої літератури.

(1) “Wake up, Sleeping Beauty", he heard Miss Withers saying, after what seemed a lapse of only a few moments. "We're almost there, Oscar, I am very happythat I never married you, for you snore like a sawmill. ”[Palmer 1978, p. 263]

(2) I ankled on deck and lamped him swimming clumsily around a houseboat like a big white whale. "Hi, Moby Dick," I said.[Bellem 1978, p. 169]

У першому прикладі ім'я Sleeping Beauty вживається іронічно при дружньому звертанні до чоловіка із звичайною зовнішністю. Семантична структура даного імені включає наступні значимі семантичні ознаки: 1) перебувати у стані сну, 2) жіноча стать, 3) приваблива зовнішність. У даному випадку перша ознака - знаходження у стані сну - обрана як спільна. Нейтралізація опозицій відбувається стосовно інших двох ознак (жіноча: чоловіча стать, приваблива: звичайна зовнішність). Ім'я Sleeping Beauty $€$ прикладом комплексної або подвійної антономазії. Спочатку це словосполучення було звичайною фразою. Потім воно стало іменем літературного персонажа. У нашому контексті спостерігається його частковий перехід до категорії загальнихімен.

У другому прикладі ім'я кита з роману Мелвілла звучить у звертанні до людини. На нашу думку, первісне ім'я містить наступні значимі ознаки: 1) тварина, 2) здатність плавати, 3) великій розмір. При алюзійному вживанні спільними є друга та третя ознаки. Але значима опозиція тварина:людина нейтралізується в даному контексті. Це призводить до створення гумористичного ефекту і певним чином характеризує автора алюзії.

Отже для розуміння алюзійного імені, читач, усвідомлюючи наявність цілого спектра семантичних ознак, які входять до його семантичної структури, 
має обрати ознаки релевантні для даного контексту.

Всі алюзійні імена проаналізовані вище як випадки метафоричної антономазії $\epsilon$ ситуативними і вживаються поряд із реальними іменами персонажів. Проте при метафоричному переносі можуть бути задіяні як постійні риси (якості) референта, так і іï/його риси, які виявляються тільки в певній ситуації. Іншими словами, персонажі можуть використовувати алюзійні імена як засоби безпосередньої реакції на поведінку, слова та вчинки їх співбесідників в окремих ситуаціях.

(1) Conveners: Charlatan! Madam Kill-joy! Mrs. Jeremiah!

Fortune Teller: And you! Mark my words before it's too late. Where'll you be?[Wilder 1988, p. 147]

(2) 'Perfect,' I said appreciatively, pulling down the anorak sleeves to coverthem. 'Thank you, Florence.' 'And Nightingale to you, too!,' she sais making a face at me. [Francis 2000, p. 159]

У першому прикладі антономазія базується на здатності референта передбачати долі людей, тобто передбачати майбутнє. Вона робить це завдяки своїм певним уродженим здібностям. Тут алюзійно вживається ім'я біблійного пророка. Нейтралізація опозиції чоловік:жінка сприяє його експресивності. Поєднання сучасної форми та старовинного імені біблійного пророка посилює ефект алюзії та виокремлює іiі.

У другому прикладі персонаж вживає алюзійне ім'я при звертанні до своєї кузини Джоани. Воно слугує засобом вираження його схвалення попередніх дій дівчини. Вона вправно і акуратно перебинтувала пошкоджені зап'ястки свого брата. Тому він використовує алюзійно ім'я медсестри Флоренс Найтінгейл, яка відома завдяки своїй відданості справі та вправності. Тут алюзійне ім'я має позитивну конотацію.

Хоча метафорична антономазія є окремим випадком актуалізації алюзії на рівні персонажів, вона все ж таки опосередковано адресована читачам. Ефект алюзії полягає в ії розпізнанні читачем. Отже, у наведеному вище прикладі із Флоренс Найтінгейл адресат розпізнає алюзію мовця та відповідно реагує на неї. На нашу думку, більшість читачів теж легко розпізнають цю алюзію та зрозуміють їі значення. Проте в деяких інших ситуаціях персонажадресат не може розпізнати алюзію і змушений просити пояснення у співбесідника.

(1) "Charles, my son, my son." 
"How do you mean Charles?"

"Do you have to be rich, Allen? Do you have to?"[Steinbeck 1985, p.69]

(2) Chasuble. ... But I must not disturb Egeria and her pupil anylonger.

Miss Prism. Egeria?My name is Letitia, Doctor.[Wilde 1981, p. 98]

$\mathrm{У}$ першому прикладі персонаж ймовірніше за все має на увазі Чарльза Бона (одного 3 персонажів роману Фолкнера «Авесалом, Авесалом»), звертаючись до свого сина Алена. У другому прикладі персонаж алюзійно вживає ім'я з римської міфології. В даних прикладах експлікація нездатності адресата визначити алюзію виявляс невідповідність між обсягами фонових знань персонажів і таким чином надає читачам додаткову інформацію про них. Це в свою чергу допомагає читачам зробити нові висновки стосовно персонажів та стосунків між ними.

Реакція читачів на дані алюзії буде варіюватися від однієї особистості до іншої. Ті читачі, які розпізнають алюзію, будуть задоволені тим, що вони змогли це зробити. А ті читачі, які не зрозуміли значення алюзійних імен, все ж таки можуть відчути якісь відхилення від текстової норми. Вживання алюзійних імен поряд із реальними іменами персонажів буде деавтоматизувати сприйняття тексту такими читачами. На нашу думку, частини тексту з ситуативними алюзійними іменами вирізняються на фоні всього тексту, де реальні імена персонажів $€$ нормою.

Ще одним способом посилення впливу алюзійної антономазії на читача $\epsilon$ зіставлення алюзійного імені з частиною висловлювання, яка належить до іншого стилю (регістру) або висловлювання, яке містить алюзійне ім'я із суміжним висловлюванням в межах одного мовленнєвого обміну.

(1) 'So long, Savior!' 'Steinbeck 1985, p. 24]

(2) 'Do you know what son of a bitch you are?'

'Yes, O Daughter of Jerusalem. '[Steinbeck 1985, p. 24]

У першому прикладі алюзійне біблійне ім'я вживається із розмовною фразою «Пока!» в одному висловлюванні. В другому прикладі алюзійне ім'я із Біблії зіставляється із лайкою в попередньому висловлюванні. В обох випадках використання алюзійних імен надає іронічної та саркастичної тональності мовленню персонажів.

Проаналізувавши цілу низку прикладів із вторинними номінаціямизвертаннями, можемо дійти висновку про існування декількох видів їх вмотивованості, а саме: об’єктивної, асоціативної (суб’єктивної) і мовленнєвої. 
Під об'єктивною - ми розуміємо мотивацію, яка базується на якійсь об'єктивно притаманній адресату або характерній для нього ознаці.

(1) Ellie (groaning) Oh! Even the hair that ensnared him false! Everythingfalse!

Mrs. Hushabye. Pull it and try. Other women can snare men in their hair; butI canswing a baby on mine. Aha! You can't do that, Goldilocks. [Shaw 1989, p. 105]

(2) "There is no supposition about what he's done. He went to the Alcazar Arms at eight fifteen tonight and throttled Ruby Rose Reading to death, Angel Face." And that was the first time I heard myself called that. [Woolrich 1978, p. 235]

У першому прикладі такою ознакою $є$ золотаве волосся дівчини, а в другому - приваблива зовнішність.

Асоціативна або суб'єктивна мотивація передбачає виникнення у мовця (номінатора) різноманітних асоціацій, які спонукають його до вживання вторинних номінацій-звертань. Наведемо декілька прикладів:

(1) He called them all killers.

"Hi-ya, Killer", he would say to Sam. ...'Look, Killer," he would say to Dopey, "I got a horse in this next race that's a cinch. "'Saroyan 1975, p. 111]

(2) Bending to switch off the light, I continued the motion and attempted to kiss him. ... My lips fell on the creased space of skin just beside one corner of his mouth. "O.K., frog," I said. [Updike 1987, p.407]

(3)Billy. Smooth move, Norman.

Norman. Thanks, cool breeze. That's give talk, Ethel. [Saroyan 1975, p.94]

Перший приклад ми взяли 3 оповідання В. Сарояна «Миша». Дія відбувається в середовищі нікому не потрібних людей, які опинилися на дні і майже втратили людське обличчя. Власні невдачі та приниження породили в них не співчуття до ближнього, а жорстокість і зневагу до слабого. Своїми словами та вчинками вони вбивають все людяне в собі та інших. Ось чому головний герой даного оповідання на ім'я Миша (воно символізує його загнаність та зацькованість) називає їх вбивцями, хоча знає їх справжні імена. Ці імена подаються для контрасту в авторському вводі прямої мови. Спочатку слово «вбивці» зустрічається в авторському тексті як звичайний іменник. Потім воно лунає як антономазії-звертання, які позначають різних адресатів. Для мовця (номінатора) вони - представники одного клану, страшної, руйнівної сили. На його думку, вони не достойні звичайних людських імен. В даному контексті це слово в позиції звертання зберігає свою негативну конотацію, 
тобто адгерентна конотація не протиставляється інгерентній. Вживаючи згадані антономазії-звертання, мовець виражає своє негативне ставлення до адресатів, протест проти їхньої жорстокості.

У другому прикладі мовець адресує зоометафоричне звертання своєму прийомному синові. Перед цим він розповідав хлопчику казку власного авторства про незвичайне та кумедне жабенятко. I незграбний, беззахисний хлопчина-підліток асоціюється у мовця із жабенятком з його казки. В даній ситуації метафоричне звертання має позитивні конотації. Про це свідчить дія мовця, яка передує звертанню та виражається дієсловом «kiss».

У третьому прикладі представлена ситуація спілкування діда та онукапідлітка. Вони знаходяться в човні на озері. В'юнкий, рухливий онук асоціюється у діда із прохолодним легким вітерцем, який віє на озері. Ось чому дідусь вживає таке метафоричне звертання.

При мовленнєвій мотивації стимулом для мовця - номінатора слугує попередня репліка співрозмовника або якась иї частина. Наприклад:

"Oh, brother, I'm clean”, Hall said. "I wish I was always so clean as I am on this one. I'm so clean, I glisten, I shine, I gleam." ... They started for the door. At the door Carella turned. “Oh. One more thing, Sun God. ” [McBain 1998, p. 124]

У цьому прикладі метафоричне антономазія-звертання зустрічається в діалозі колишнього засудженого та інспектора поліції. Антономазія-звертання вживається інспектором іє реакцією на слова співбесідника, який намагається довести свою повну непричетність до справи. Інспектор не може не бути уїдливим щодо співбесідника, який далеко не такий вже бездоганний, яким хоче себе представити. В основу перейменування мовець (інспектор) бере ознаки, які виражені в мовленні співбесідника за допомогою синонімічних дієслів «glisten», «shine», «gleam». У цій ситуації антономазія-звертання звучить саркастично, уїдливо.

У контексті зазвичай експлікуються мотиви вибору ознаки, яка лежить в основі перейменування або подається інформація, яка робить мотиви та інтенції мовця зрозумілими для читача. Така інформація зустрічається як в авторському тексті, так і в мовленні персонажів. Вона частіше подається в передтексті, ніж в посттексті.

У першому з наведених нижче прикладів в передтексті подається опис зовнішності і вказується та ознака адресата, на базі якої утворюється антономазія-звертання в наступній репліці одного з персонажів. 
У другому прикладі така ознака зовнішності адресата представлена в посттексті після репліки персонажа, яка містить антономазію-звертання.

(1) Around a corner we looked at a short dirty wop in a purple silk shirt who sat in a wired-together office chair... Red stepped behind him noiselessly. He said gently: "Hi, Shorty. How's all the bambinos" [Chandler 1985, p. 93].

(2) He laughed lightly. "Go back to your post, Slim. I'll look into this. He movedlazily in front of me and the tall one appeared to fade into the dark. [Chandler 1985, p. 96]

Мотивація вибору ознаки у вторинних номінаціях-звертаннях може бути експлікована за допомогою порівняння. Номінатор-мовець вживає антономазіізвертання, коли не знає імені адресата або намагається виразити в образній, експресивній формі своє ставлення до адресата, дати оцінку тим чи іншим його якостям. У першому випадку перейменування відбувається, як правило, на основі характерної зовнішньої ознаки. В другому випадку можливості для вибору ознаки, на якій базується перейменування, значно ширші.

Таким чином, у результаті проведеного дослідження можемо стверджувати, що алюзійні власні імена, розглянуті вище як приклади антономазії, є складовими системи експресивних засобів художнього тексту. Їхня експресивність формується завдяки поєднанню метафоричного переносу i емоційної оцінки. В контексті вони можуть набувати позитивних або негативних конотацій та виражати не/схвалення персонажем-мовцем поведінки, мовлення, зовнішності тощо персонажа-адресата в певних ситуаціях. Алюзійні власні імена використовуються для створення гумористичного, іронічного ефекту та для характеристики персонажів. Мотивація вживання антономазій-звертань експлікується в прямому мовленні із представленням ознаки, яка лежить в основі перейменування, як в репліці мовця, так і в репліці адресата. До того ж, ця ознака може бути представлена в авторському тексті та авторській ремарці. На нашу думку, всім представленим засобам притаманна різна ступінь експлікованості мотивації: від найвищої - для безпосереднього пояснення в прямій мові, до найменшої- при виведенні із ситуації.

\section{Література}

1. Азнаурова, Э. С.«Стилистический аспект номинации словом как единицей речи.» Языковая номинация. Виды найменований (1977): 86-128.

2. Телия, В. Н.«Вторичная номинация и ее виды.»Языковая номинация. Виды 
найменований (1977): 129-221.

3. Perri, C. «On Alluding.» Poetics 7 (1978): 289-307.

\section{Список джерел ілюстративного матеріалу}

4. Bellem, R. L. The Lake of the Left-Hand Moon (NewYork, A Mentor Book, 1978), 414.

5. Chandler, R. Farewell, my lovely. Stories (Harmondsworth, Penguin Books, 1985), 368.

6. Fowles, J. The Ebony Tower. Eliduc. Enigma (Moscow, Progress Publishers, 1980),246.

7. Francis, D. Nerve (London, Sydney, Pan Books, 2000), 219.

8. McBain, E. Killer's Payoff (Harmondsworth, Penguin Books, 1998), 160.

9. Palmer, S. The Riddle of the Twelve Amethysts (NewYork, A Mentor Book, 1978), 414.

10. Saroyan, W. Selected Short Stories (Moscow, Progress Publishers, 1975), 464.

11. Shaw, J. B. Heartbreak House (Harmondsworth, Penguin, 1989), 160.

12. Steinbeck, J. The Winter of Our Discontent (Moscow, Vyssaja Skola, 1985),271.

13. Updike, J. Of the Farm (Moscow, Raduga Publishers, 1987), 496.

14. Wilde, O. The Importance of Being Earnest (London, Bloomsbury, 1981), 144.

15. Wilder, Th. Heaven's My Destination (Moscow, Raduga Publishers, 1988), 382.

16. Woolrich, C. Angel Face (NewYork, A Mentor Book, 1978), 414.

\section{References}

1. Aznaurova, E. S. «Stilisticheskiy aspect nominatsii slovom kak jedinitsei rechi.»Yazykovaja nominatsiya. Vidy naimenovaniy [«Stylistic aspect of nomination by a word as a unit of speech.» Language nomination. Types of nominations] (1977): 86-128 (in Russ).

2. Teliya, V. N. «Vtorichnaya nominatsiya i jeje vidy.» Yazykovaja nominatsiya. Vidy naimenovaniy [ «Secondary nomination and its types.» Language nomination. Types of nominations] (1977): 129-291 (in Russ).

3. Perri, C. «On Alluding.»Poetics 7 (1978): 289-307.

4. Bellem, R. L. The Lake of the Left-Hand Moon (NewYork, A Mentor Book, 1978), 414.

5. Chandler, R.Farewell, my lovely. Stories (Harmondsworth, Penguin Books, 1985): 368.

6. Fowles, J.The Ebony Tower. Eliduc. Enigma (Moscow, Progress Publishers), 246.

7. Francis, D. Nerve (London, Sydney, Pan Books, 2000), 219.

8. McBain, E. Killer's Payoff (Harmondsworth: Penguin Books, 1998), 160.

9. Palmer, S. The Riddle of the Twelve Amethysts (NewYork, A Mentor Book, 1978), 414.

10. Saroyan, W. Selected Short Stories (V., Progress Publisher, 1975), 464.

11. Shaw, J. B. Heartbreak House (Harmondsworth, Penguin, 1989), 160.

12. Steinbeck, J. The Winter of Our Discontent (Moscow,Vyssaja Skola, 1985), 271.

13. Updike, J. Of the Farm (Moscow, Raduga Publishers, 1987), 496.

14. Wilde, O. The Importance of Being Earnest (London, Bloomsbury, 1981), 144.

15. Wilder, Th. Heaven's My Destination (Moscow,Raduga Publishers, 1988), 382.

16. Woolrich, C. Angel Face (NewYork, A Mentor Book, 1978), 414. 
Стаття надійшла до редакиії 26.08.2018 Перевірено на плагіат 28.08.2018 p. УДК 811.133.1 унікальність - $96.2 \%$

\title{
ПОНЯТТЯ МОВНОЇ НОРМИ ТА ФРАНЦУЗЬКОЇ ЛІТЕРАТУРНОЇ МОВИ 3 ПОЗИЦЇ̈ СОЦІЛІНГВІСТИКИ
}

\author{
Хайдар Даріна Мохамедівна, haidaryshka15@gmail.com \\ аспірант \\ Київський національний університет імені Тараса Шевченка, \\ Інститут філології
}

У статті розглядаються проблеми норми, особливості функиіонування сучасної франиуької мови, а саме ситуативна варіативність, яка впливає на вибір певних мовних одиниць, відповідно до ситуації комунікативного акту. Дане дослідження є актуальним тому, що при дослідженні мови посутне значення має вивчення ї̈ норми на всіх рівнях - граматичному, лексичному, фонетичному. Разом із розвитком мови, з появою в ній нових рис, модифікується також і ї̈ норма. Іншими словами, норму необхідно розглядати не в статиці, а в динаміщі, приймаючи до уваги «динамічний аспект норми». У лінгвістиці термін «норма» використовується у двох значеннях - широкому та вузькому. У широкому сенсі норма - ие традиційно і стихійно сформовані способи мови, щчо відрізняють одну мовну систему від інших (у иъьому розумінні норма близька до поняття узусу, тобто загальноприйнятих, усталених способів використання иієї мови). У вузькому сенсі норма - це результат иілеспрямованої кодифікації мови. Таке розуміння норми нерозривно пов'язане з поняттям літературної мови, яке інакше можна назвати нормованим, або кодифікованим.

Ключові слова: мовна норма, сучасна франиузька мова, сочіолінгвістика, літературна мова

\section{ПОНЯТИЕ ЯЗЫКОВОЙ НОРМЫ И ФРАНЦУЗСКОГО ЛИТЕРАТУРНОГО ЯЗЫКА С ПОЗИЦИИ СОЦИОЛИНГВИСТИКИ}

\author{
Хайдар Дарина Мохамедовна, haidaryshka15@gmail.com \\ аспирант \\ Киевский национальный университет имени Тараса Шевченко, \\ Институт филологии
}

В статье рассматриваются проблемь нормы, особенности функционирования современного франиузского языка, а именно ситуативная вариативность, которая влияет на выбор определенных языковых единии, в 
соответствии с ситуацией коммуникативного акта. Данное исследование актуально тем, что основное внимание уделено изучению нормы на всех уровнях языка - грамматическом, лексическом, фонетическом. Вместе с развитием речи, с появлением в ней новых черт, модифицируется также и ее норма. Иными словами, норму необходимо рассматривать не в статике, а в динамике, принимая во внимание «динамический аспект нормы». В лингвистике термин «норма» используется в двух значениях - широком и узком. В широком смысле норма - это традиционно и стихийно сложивщиеся способы языка, отличающие одну языковую систему от других (в этом смысле норма близка к понятию узусу, то есть общепринятым, устоявшимся способам использования этого языка). В узком смысле норма - это результат ичеленаправленной кодификации языка. Такое понимание нормы неразрывно связано с понятием литературного языка, которое по-иному можно назвать нормированным, или кодифицированным.

Ключевые слова: языковая норма, современная французская речь, сочииолингвистика, литературный язык.

\title{
LANGUAGE STANDARD AND FRENCH LITERARY LANGUAGE ACCORDING TO SOCIOLINGUISTICS
}

\author{
Khaidar D., haidaryshka15@ gmail.com \\ PhD Student \\ Taras Shevchenko National University of Kyiv, \\ Institute of Philology
}

The article is focusing on the problems of standards, the peculiarities of functioning of modern French language, such as situational variability which influences the choice of certain language unit according to a situation of the communicative act. This research is relevant since the essential value is given to the study of the language norm at all levels of language organization - grammatical, lexical, phonetic. Together with development of the speech, with emergence of new features in it, its norm is modified as well. In other words, the norm needs to be considered not in a statics, but in dynamics, in view of "dynamic aspect of norm". In linguistics the term "norm" is used in two ways - broad sense and narrow. In a broad sense, the norm is a traditionally and spontaneously established methods of language that distinguish one language system from the others (in this sense, the norm is close to the concept of "usage", i.e. generally accepted, well-established ways of using this language). In the narrow sense, the norm is the result of purposeful codification of a language. Such understanding of norm is closely connected with a concept of the literary language which otherwise could be called normalized or codified language.

Key words: language standard, contemporary French, sociolinguistics, literary 
language.

Мета та зумовлені нею основні завдання нашого дослідження полягають у структуризації варіативності функціонування сучасної французької мови.

Під мовною нормою, зазвичай, розуміють сукупність загальновживаних мовних засобів та правил їх уживання, прийнятих у суспільстві в конкретну епоху. Найбільш широку мовну норму становить національна мова у всьому різноманітті не тільки форм свого існування, а й потенційних можливостей, тобто мова в такому разі розуміється як система. Відтак, особливо доречним є розмежування понять «система мови» та «мовна система».

Система мови позначає мову як систему норм, структурних рівнів $\mathrm{i}$ внутрішніх закономірностей iï функціонування, тобто ту мову, яка представлена в академічних словниках і граматиках, яка виникає в результаті дії різних лінгвістичних законів.

Мовна система розглядає мову в загальнокультурному, соціальному контексті, тобто мовна система як поняття містить у собі не тільки кодифіковану мову, а й мовну свідомість, що виражає уявлення людей різних соціальних верств про мову, а також некодифіковані функціональностилістичні шари, тобто все суспільне оточення академічної мови.

Наголосимо, закони системи мови, перш за все, регламентують акцентологічні, словотворчі та граматичні аспекти норми. Однак у розробленій Е. Коссеріу тріаді «система-норма-узус» не менш важливими є питання узусу, тобто загальноприйнятого вживання мовної одиниці, на відміну від іï оказіонального вживання [Коссериу, 1963]. Ці питання безпосередньо пов'язані 3 проблематикою вибору слова 3 варіативної парадигми та його функціонування в різних сферах і ситуаціях спілкування.

Натомість В.Г.Гак у своїх дослідженнях, присвячених питанням мовної норми, зазначає, що в сучасному мовознавстві розрізняють два основних аспекти цього поняття - об'єктивну мовну норму, загальноприйняту в конкретному соціальному колективі форму мовних засобів, та оцінювальну, аксіологічну норму, яка встановлює правильність або неправильність цих об'єктивних норм. Науковець висловлює думку про те, що цій відмінності в загальних рисах відповідає розрізнення описової / дескриптивної (об'єктивної) 
та приписуючої / прескриптивної (суб’єктивної) норм [Гак, 1984: 7]. 3 цією відмінністю корелюють поняття норми та її кодифікація.

$Ф$. Ельгорскі розрізняє три аспекти розуміння норми:

1. Об’єктивна, «дескриптивна» норма - поняття, співвідносне 3 поняттями системи, структури та узусу мови.

2. Приписуюча, «прескриптивна» норма передбачає відбір мовних засобів 3 точки зору їх правильності. Саме під впливом цієї норми створюється літературний стандарт, який «приписується» носіям мови як найкращий спосіб вираження.

3. Норма - зразок, що розробляється 3 методичною метою, зокрема зразок використання мовних засобів [Helgorski, 1982, 1].

Норма - це системне явище, багатошарове і складне, а кожен варіант мови, кожна форма передбачає наявність власної норми. Існує загальнонаціональна норма, якою в основному володіють усі, для кого мова $є$ рідною. Крім того, можна говорити про діалектну норму, про просторіччя, про норми літературної мови в іiі усній та письмовій формах. $€$ також більш приватні норми окремих функціональних стилів: норма розмовної мови, норма стилю ділового спілкування та ін. Отже, мова регламентується кількома нормами.

Між окремими нормами існують так звані «пограничні зони», де й відбувається взаємодія та взаємопроникнення різних норм. Тому в будь-якій нормі, у тому числі й у літературній мові, існують коливання, варіантні явища. При цьому, логічною є можлива відома невизначеність у визнанні конкретних мовних фактів нормативними або ненормативними.

Відомо, що норма стабільна, але разом із тим, вона допускає варіювання мовних засобів: поряд з абсолютною нормою існують варіативні норми. Абсолютної норми повинні дотримуватися всі носії мови, порушувати цю норму можуть лише ті, для кого ця мова не є рідною, або носії діалектної мови й просторічь. Варіативні норми можуть бути «імперативними» в тому разі, якщо відхилення від норми є частотними, але вважаються порушенням правил мови, або «диспозитивними», не строго обов'язковими, якщо норма допускає стилістичні або нейтральні варіанти [Гак, 1984, 10].

Літературна норма єдина та загальнообов'язкова для всіх, хто говорить цією мовою, вона консервативна, спрямована на збереження засобів і правил їх використання, накопичених у суспільстві попередніми поколіннями. У той 
же час, літературна норма не статична, а мінлива в часі, тобто передбачає динамічну взаємодію різних способів мовного вираження в залежності від умов спілкування [Крысин, 2002, 82].

Динамічний аспект мови безпосередньо пов'язаний 3 узусом або нормою мови, що є «сукупністю тенденцій у використанні мовних засобів» [Денисова, 2002, 86]. Норма мови відноситься до конкретної форми реалізації системних протиставлень, що не передбачають вибір. Узус (норма мови), тобто реалізація в мові форм, що надаються системою i нормою, $\epsilon$ варіативним, а отже, допускає вибір. I те, що сьогодні сприймається як відхилення від норми, через 20-30 років може бути визнано саме нею [Денисова, 2002, 86]. Узус відображає специфіку мови в аспекті іiі функціонування. Він може помітно відрізнятися від норми мови, оскільки допускає різного роду відхилення від неї [Гак, 1985, 28].

Джерела поновлення літературної норми різноманітні. Перш за все, це усна мова. Вона рухлива, у ній виникають різні новоутворення, що не схвалюється офіційною нормою. При неодноразовому повторенні багатьма людьми ці нововведення можуть проникати в літературний обіг і складати конкуренцію фактам, що встановлені традицією.

В оновленні норми, в її зміні важливим є також соціальне середовище, у якому аналізоване новоутворення набуває поширення. Чим вища «суспільна вага» тієї чи іншої соціальної групи, їі престиж у суспільстві, тим легше ініційовані нею мовні нововведення набувають поширення в інших групах носіїв мови.

Дослідження питань норми з позицій соціальної лінгвістики змінює уявлення про норму як ознаку, характерну винятково для літературної мови. При підході до мови як до сукупності різних соціально-диференційованих форм існування (літературна мова, соціальні й територіальні діалекти, просторіччя та ін.) на перший план висувається положення про те, що норма $\epsilon$ ознакою не тільки літературної мови, а й інших компонентів аналізованої мовної системи (розмовної мови, діалектів тощо).

Таким чином, актуалізується твердження про те, що варіативність мовних засобів (як прояв літературної норми) забезпечує функціональностилістичну диференціацію мови. Разом із тим, саме кодифікована і стабільна норма літературного стандарту $є$ тим нейтральним фоном, без якого неможливе сприйняття стилістично зниженої лексики взагалі [Туманян, 1994]. 
Усі форми існування мови в своєму соціумі становлять мовну норму цього соціуму. Природа мовних норм однакова і в літературній мові, і в діалектах або арго, оскільки головне, на основі чого створюється саме явище мовної норми, - це наявність у мовців «мовного ідеалу».

Відтак, логічним є висновок про наявність у мові не однієї, а кількох норм, залежно від соціолінгвістичних особливостей комунікації.

Норма, яка виявляється в кодифікованій нормативності, $\epsilon$ літературною, або стандартною «нормою першого рівня». Вона $€$ нейтральним фоном, на якому проявляються відхилення від неї, характерні як для форм існування мови, так і для окремих підсистем цих форм або конкретних мовних одиниць усіх рівнів. Натомість різні соціолекти (арго, професійні та корпоративні жаргони) мають власні норми, які визначаються як соціальні норми «другого рівня). Обидві норми в межах національної мови утворюють загальну соціолінгвістичну норму, яка може існувати у трьох видах:

1) домінування норми першого рівня над нормою другого рівня;

2) паритетне співіснування обох норм;

3) домінування норми другого рівня [Хомяков, 1997, 150].

Наголосимо, норма може бути лінгвістичною та соціолінгвістичною. У поняття соціолінгвістичної норми включається також сукупність правил, відповідно до яких ті, що говорять, обирають мовну підсистему або окремі елементи для побудови соціально коректного висловлювання.

Засадничим положенням у нашому дослідженні $\epsilon$ те, що норма проявляється в нормативності, яка є постійною мовною якістю, без якої не можуть функціонувати жодні форми існування мови і жодні одиниці всіх мовних рівнів. Нормативним можна визнати все те, що приймається комунікантами в конкретному комунікативному акті, в соціумі і суспільстві в цілому.

Для забезпечення основної функції мови - комунікативної - існування соціолінгвістичної норми є досить важливим, оскільки за кожною сферою спілкування закріплена певна підсистема мови. Порушення правил вибору мови або підсистеми може спричинити нерозуміння між суб'єктами, що говорять [Саблина, 1982, 26].

Молодіжна лексика надзвичайно рухлива, вона має некодифікований характер і підпорядковується, перш за все, соціолінгвістичній нормі, яка менш стійка, ніж мовна. Періодично виникають інновації, як у мові, так і в 
суспільстві, які становлять інтерес, відповідно, і з боку власне мовців, і з боку соціолінгвістів.

Дослідження сучасної французької мови виявляють зміни у співвідношенні нормованих i ненормованих мовленнєвих уживань. Йде постійний процес формування єдиної уніфікованої мови на всіх мовних рівнях: фонетичному, лексичному, граматичному.

У сучасній французькій мові простежуються зміни у співвідношенні нормованих i ненормованих мовленнєвих вживань. Тобто відбувається постійний процес формування єдиної для всіх усередненої, уніфікованої мови на всіх мовних рівнях: фонетичному, лексичному, граматичному.

Під терміном «літературна мова» розуміють оброблену форму будьякої мови, яка може існувати як в усній, так і в письмовій формах. Літературна мова як категорія історичної лінгвістики зазнає змін: на різних етапах еволюції вона набуває різних якостей. Літературна мова донаціонального періоду суттєво відрізняється від мови національного етапу: як остання в соціально-комунікативній системі домінуюча форма існування мови остання підлягає уніфікації, кодифікується, набуваючи ознаки «стандартної» мови [Туманян, 1985, 9].

Отже, літературна мова виділяється на тлі національної мови i знаходиться в певному протиставленні до решти форм існування національної мови, що не належать до літературних. Літературна мова протиставляється нелітературним сферам, до яких належать соціальні діалекти. Дослідження розвитку лексичного складу соціального діалекту може мати посутне значення для розуміння динаміки літературної мови. Так, сьогодні зміщуються межі між окремими формами існування літературної мови та нелітературними утвореннями. Літературна мова, перебуваючи в русі, піддається стилістичній диференціації, як правило, під впливом необхідності в більш розчленованій і точній мовній комунікації.

Підпорядкована нормі літературна мова, що має потужний арсенал тонко диференційованих засобів, розрахована на вдумливе проникнення у зміст сказаного і вимагає чіткої вимови слів, яка іноді $є$ досить складною для артикуляційного апарату людини, сьогодні не відповідає вимогам розмовної мови. Тому літературна мова послуговується лексичними та граматичними формами, запозиченими з просторічних і жаргонних систем, де закон економії мовних зусиль і закон аналогії не мають нормативних перешкод. 
Слід зазначити, що літературна мова не була б надійним засобом спілкування, не володіла б багатими засобами вираження, якби не запозичила все найкраще, що $є$ в різних соціальних діалектах, професійних мовах i говорах.

Доволі складно встановити межі французької літературної мови в національній мові, особливо іiі нижньої межі, або кордону між власне літературною мовою та нелітературними утвореннями національної мови. У кожній національній мові існують принаймні дві радикально протилежні форми існування: літературна і нелітературна. Поряд із літературною мовою, яка характеризується загальнонародною значущістю та обов'язковістю, більшість мовознавців відносять до нелітературних утворень національної мови територіальні й соціальні діалекти: молодіжний жаргон, арго, сленг тощо. Нелітературні форми існування національної мови відіграють значну роль у суспільному житті і суттєво впливають на форму самої літературної мови. Таким чином, відбувається взаємодія між літературною та нелітературною формами національної мови.

Усі форми існування мови, врешті-решт, утворюють мову як певну систему систем. Варіанти територіального та соціального характеру не тільки мають свої сфери функціонування, а й різняться один від одного своєю внутрішньоструктурної організацією, залишаючись при цьому взаємопов'язаними системами, що утворює одиницю більш складного порядку - архісистему (мова народу в цілому) [Туманян, 1985].

На сучасному етапі в лінгвістиці все більшого поширення набуває польова модель дослідження мови. Польові утворення відображають положення про системність лексики та доцільність структурного підходу до вивчення мови. Цей факт підтверджує уявлення про мову як про систему систем, які взаємодіють між собою [Попова, Стернин, 1989, 7].

Слова, які утворюють лексичний корпус мови, можуть бути об'єднані в синонімічні ряди, тематичні групи, лексико-семантичні групи, лексикосемантичні поля, асоціативні угруповання тощо.

Тому застосування польового підходу дозволяє суттєво розширити дослідження мовного матеріалу. Усе це визначає перед науковцями завдання всебічного дослідження не окремих, а семантично пов'язаних слів у межах різних лексико-семантичних явищ - взаємообумовлених і взаємопов'язаних.

Однією $з$ особливостей функціонування французької мови нині $є$ 
взаємодія між літературним та розмовним варіантами мови, з одного боку, та вплив некодифікованих лексичних одиниць на розмовну мову, з іншого. У результаті цього процесу в писемних текстах офіційного характеру з'являються мовні одиниці, що прийшли зі знижених регістрів усного мовлення. Технічне вдосконалення способів передачі інформації і постійно зростаюча роль аудіовізуальних засобів у системі масової комунікації сприяють виходу розмовної мови за межі побутової комунікативної сфери, елементи якої функціонують у тих галузях і на тих рівнях, які традиційно вважалися кодифікованими формами (наприклад, публічні виступи, що представлені в писемних засобах масової інформації).

Французька мова на сучасному етапі свого розвитку характеризується демократизацією та інтелектуалізацією. Перша тенденція проявляється в тому, що розмовна мова проникає в раніше недоступні їй сфери. Друга пов'язана 3 проникненням політики й науки в галузь повсякденного спілкування, у результаті чого розмовна мова збагачується новими термінами, лексичними інноваціями.

Так, Л. Гільбер зауважує, що зі зміною морально-етичних засад змінюється характер відносин у суспільстві, швидко зникають табу на вживання лексики, відбувається взаємопроникнення регістрів мови, що, логічно позначається на лексичній нормі [Guilbert, 1972, 47].

Інший французький соціолінгвіст Л.-Ж. Кальве стверджує, що мовні форми, які розглядаються як помилкові, іноді стають «нормативними», а знижений лексикон входить до загальновживаної мову, його розуміють усі, хоча й уживається він відповідно до ситуації спілкування [Calvet, 1994, 9]. При цьому дослідник підкреслює, що знижена лексика постійно поповнює загальний лексикон, сприяючи втрати їі первісного зниженого маркування. Більше того, знижені одиниці, які перестають бути засекреченими, стають символом для тих, хто хоче підкреслити свою відособленість і свій код [Calvet, 1994, 75-77].

Відтак, соціально-знижені одиниці мови, з одного боку, є відхиленням від загальної норми, з іншого, є приватною нормою. У межах цієї норми є своя варіативність. Зазвичай, виділяють такі знижені регістри французької мови: фамільярний, просторічний та арготичний. Розмежування цих рівнів у лексикографії викликає певні труднощі. У різних словниках ті ж самі лексичні одиниці часто належать до різних регістрів мови. Однак наявність широкого 
контексту їх уживання дозволяє диференціювати фамільярний, просторічний, арготичний регістри в стилістичному та прагматичному аспектах.

До фамільярного регістру у французькій традиції належить найменш знижена лексика. У соціолінгвістиці фамільярна мова визначається як мова повсякденного спілкування, як основа розмовної мови всіх класів суспільства.

При визначенні фамільярного регістру мови більшість лінгвістів вказують на особливості ситуації спілкування [Calvet, 1994, 195]. Поняття «фамільярна мова» відображає такі моменти:

1. Фамільярна мова як специфічна мовна підсистема зі своєю лексикою відрізняється від загальнонаціональної мови, але не виходить далеко за межі літературної норми.

2. Фамільярна мова є особливим «мовним регістром», який вказує на невимушеність та дружній характер спілкування.

Фамільярний рівень (найменш знижений порівняно 3 іншими регістрами мови в системі зниженої лексики) відрізняється від інших мовних підсистем ситуацією спілкування та $є$ прагматично насиченим. Так, співрозмовники, які хочуть порозумітися в неофіційній ситуації, вживають одиниці цього рівня. При чому лексика вказаного регістра відрізняється від лексичних одиниць інших регістрів зниженою лексики швидше позитивним, ніж негативним компонентом значення. Це пов'язано з досить близькими стосунками між співрозмовниками в сімейному чи дружньому колі.

Фамільярний рівень спілкування характерний майже для всіх соціальних прошарків суспільства.

Просторічний регістр є універсальним для національних мов, але в кожній із них є певні особливості, що визначає взаємозв'язки просторічного реєстру з літературною мовою.

Просторіччя розуміється як сукупність мовних реалізацій, які вважаються типовими для неосвіченої чи недостатньо освіченої частини суспільства і такими, що порушують літературну норму [Calvet, 1994]. При цьому багато лінгвісти відзначають нестабільність та неоднорідність просторіччя [Gadet, 1992, 122], а також відсутність чітких меж між просторіччям та фамільярною мовою, тобто вчені вказують на тенденцію до зближення аналізованих мовних явищ.

У лінгвістичних працях учених слов'янського простору просторіччя розуміється, з одного боку, як сукупність засобів мови, які перебувають за 
межами літературної норми; з іншого боку, - як набір знижених лексичних одиниць, якими однаково користуються i носії просторіччя, i носії літературної мови 3 відповідною виражальною метою [Бондалетов, 1987; Беликов, Крысин, 2001].

3. I. Хованська, розмежовуючи просторіччя та фамільярну мову, наголошує, що критерієм опозиції «фамільярна мова / просторіччя» слугують соціокультурні фактори [Хованская, 1984, 83]. Якщо вживання першої (фамільярної мови) пов'язане винятково із ситуацією, то другий спосіб вираження (просторіччя), що проявляється головним чином у невідповідності літературним нормам, властивий недостатньо освіченим людям, більше того, він є для них основним.

Відповідно, категорія просторіччя, що належить до середньозниженого мовного регістру, також вказує на прагматичний характер уживання одиниць у мовленні.

Арго, у широкому розумінні цього терміна, визначається по-різному в дослідженнях вітчизняних та зарубіжних лінгвістів.

В. Д. Бондалетов вважає арго сукупністю слів та фразеологічних зворотів, які вживаються передусім декласованими елементами [Бондалетов, 1987, 74].

В. С. Слістратов визначає арго як одне з найбільш суперечливих явищ мовної культури. Дослідник розподіляє елементи арго за трьома основними рівнями та характеризує їх відповідно до трьох основних систем.

Так, перший рівень закритої системи - вища герметика, відповідна перша система є закритою (арготизми функціонують тільки в межах певної соціальної групи і не можуть переходити в інші рівні цієї системи).

Другий рівень системи - соціально-побутовий, або матеріальнодіяльнісний, до якого автор відносить в основному професійні арго. Друга система - відкрита (можливий перехід арготизмів із системи в систему або їхній рух у межах системи).

Третій рівень системи - стихійна, або ігрова герметика. Третя система відкрита (ця система передбачає вільний вихід арготизмів у навколишній світ) [Елистратов, 1994, 597].

Таким чином, арго, за В. С. Слістратовим, є узагальнено-абстрактним поняттям, що відображає культуру розвитку суспільства і людства в цілому.

У нашій роботі арго розглядається як найбільш знижений регістр, що 
відрізняється від інших пейоративною експресією.

У французькій лінгвістиці арго традиційно розглядалося як соціальний діалект, різновид мови, яким послуговувалися передусім декласовані елементи суспільства: професійні злодії, бандити, жебраки, тобто маргінальні представники суспільства. Основною функцією арго була криптолалічна функція; тобто цей «соціальний діалект» був створений передусім для того, щоб мова була не зрозумілою для «чужих», тобто з метою самозахисту.

У сучасних наукових студіях досить часто вживається i термін «загальне арго» (argot commun), що включає також поширені слова традиційного арго [Fraш; ois-Geiger, 1991]. Так, Л.-Ж. Кальве вживає термін «сучасне арго» (argot moderne) на позначення мови, яка вже не є секретною, а просто відображає певну манеру висловлення. Сучасне арго включає лексику арготичного походження, що вживається людьми, які не мають жодного відношення до злочинного світу. Це мова, яка використовується у ЗМІ, в літературі, реєструється у словниках, постійно оновлюється та змінюється відповідно до модних тенденцій [Calvet, 1994].

Іноді термін «арго» вживають на позначення мови певних професійних i соціальних груп, тобто того, що називають професійними і груповими жаргонами. Таким чином, можна зустріти поняття «арго студентів, солдатів, артистів, лікарів» тощо.

При цьому зауважимо, власне слово argot в однині вживається на позначення злодійського арго, а в множині argots, або з визначенням (argots des étudiants, argots des typographes), - професійних і групових арго (жаргонів) [Gadet, 1992, 103].

Відповідно до проаналізованого нами матеріалу, арго - найбільш знижений мовний регістр, який відрізняється від інших регістрів мови специфічним словником. Вживається арго, як правило, з метою приховування предмета комунікації.

Відомо, що в мовній практиці досить складно визначити точну межу між літературно-розмовним та фамільярно-розмовним різновидами мови. Як правило, показником «літературності» розмовної мови є соціокультурні характеристики іiі носія, зокрема, наявність у нього необхідного освітнього рівня. Можливість судити про деякі особливості мовної поведінки освічених людей у неофіційних умовах можна реалізується в писемних засобах масової інформації. Поряд з офіційними публічними заявами, цитованими у зниженій 
формі, в інтерв'ю, наприклад, представлені спонтанні висловлювання або фрагменти неофіційних розмов, у яких мовці реалізують свою звичну повсякденно-розмовну мовну манеру.

Для сучасної французької мови характерним є проникнення зниженої лексики до повсякденного побуту культурних людей - процес, який іще кілька десятиліть тому вважався неприпустимим. Стирання в мовному узусі кордонів між повсякденною та літературною мовою відображене також у художній літературі. На думку Ю. П. Уварова, «журналісти і політики нерідко вживають поширені слова і вирази розмовно-побутової лексики насамперед для того, щоб створити видимість атмосфери довірливого спілкування з тими, до кого вони звертаються. Зниження стильових регістрів у цьому разі продиктовано особливостями політичного життя Франції. Саме тому політичні діячі так часто застосовують образно-експресивні слова та вирази 3 фамільярно-побутового мовлення, а саме: 3 метою наближення до широких мас читачів і слухачів ...» [Уваров, 1988, 139].

Сьогодні простежується певне «розшарування» мови. Зміна в соціально-комунікативних умовах сучасної Франції (розширення комунікативних процесів у суспільстві, доступність освіти, демократизація форм і засобів спілкування) призвела до того, що літературно-мовні книжні форми втратили престижність, а в деяких комунікативних сферах вони навіть сприймаються негативно. Так, за твердженням Т. Зелдіна, про значення філософії та літератури у розвитку мови сьогодні доводиться говорити лише щодо мовних смаків меншості. «Різновиди» мови вимагають до себе такого ж ставлення, як і «справжня» французька мова, без визнання переваги стилю, прийнятого у правлячих колах » [Т. Зелдін, 1989, 286].

Таким чином, відбувається переорієнтація розмовної мови на новий оцінковий зразок, що визначається соціально-психологічними ціннісними стереотипами. Один із таких стереотипів пов'язаний із надзвичайно високою оцінкою, яку має в суспільній свідомості ознака «молодий», до складу якої входять такі характеристики, як здоров'я, краса, перспективність, динамічність. Інакше кажучи, у сучасному французькому суспільстві посутній інтерес викликають практично всі аспекти життєвої поведінки певної соціальної групи, яка виокремлюється на основі вікової ознаки.

У зв'язку з цим особливо актуальним $є$ питання стратифікаційної варіативності мови, яка пов'язана передусім із соціальною структурою 
суспільства. Означена нами варіативність відображається в тих мовних і мовленнєвих відмінностях, які виявляються між представниками різних соціальних верств і груп.

Висновки. Основні точки зору фахівців на проблему норми французької літературної мови 3 позицій соціальної лінгвістики вказують на наявність в мові різних норм, що допускають варіювання: від незначного використання елементів молодіжного соціолекта до широкого і стійкого його вживання в різних ситуаціях спілкування, що підтверджує положення про зміну лексичної складової молодіжної мови. А ось варіативність мовної норми пов'язана 3 соціально комунікативною системою мови, що виражається в різних формах існування національної мови. Мовна варіативність розглядається як система територіальних і соціальних варіантів.

\section{Література:}

1. Хомяков, В. А. «Норма как лингвостилистическое понятие и просторечие.» Актуальные вопросы английской филологии (1997): 148-151.

2. Саблина, Е.Н. «Семантические способы обогащения синонимических рядов в лексике социального диалекта.» Автореф. дис. канд. филол. наук (Москва, 1982).

3. Уваров, Ю. П., Гринева, Е. Ф., Громова, Т. Н. Словарь разговорной лексики французского языка (Москва, Просвещение, 1988), 139.

4. Зэлдин, Т. Все о франиузах, пер. с франц (Москва, Прогресс, 1989), 439.

5. Елистратов, В. С. «Арго и культура.» Словарь московского арго: Материаль 1980-1994 г2. (Москва, Русские словари, 1994), 700.

6. Бондалетов, В. Д. Социальная лингвистика (Москва, Просвещение, 1987), 159.

7. Хованская, 3. И. Стилистика французского языка (Москва, Высшая школа, 1984), 344.

8. Туманян, Э. Г. «Понятие «языковая норма» с позиций социальной лингвистики.» Проблемы языковой жизни Российской Федерации и зарубежных стран (1994): 120-123.

9. Попова, 3. Д., Стернин, И. А. Полевые структуры в системе языка (Воронеж, Изд-во ВГУ, 1989), 198.

10. Gadet, F. Le français populaire (Paris, PUF, 1992), 128.

11. Calvet, L.-J. La sociolinguistique (Paris, 1993), 127.

12. François-Geiger, D. «Argots: la cohabitation.» Europe 738 (1990): 30-35.

13. Guilbert, L. «Peut-on definir un concept de norme lexicale?» Langue française 16 (Paris, Larousse, 1972): 29-48.

14. Чиликина, О. Н. «Некоторые особенности французской разговорной речи.» Теория и история германских и романских языков в современной высшей школе России (2002): 28-32.

15. Крысин, Л. П. «О речевом поведении человека в малых социальных 
общностях: Постановка вопроса.» Языки личность (Москва, Наука, 2002): 78-86.

16. Косериу, Э. «Синхрония, диахрония и история.» Новое в лингвистике 3 (1963), 568.

17. Гак, В. Г. «Норма и толерантность.» Иностранные языки в школе 1 (1984): 7 15.

18. Helgorski, F. «La notion de norme en linguistique.» Le français modeme 1 (1982): 1-14.

\section{References:}

1. Homjakov, V. A. «Norma kak lingvostilisticheskoe ponjatie i prostorechie.» Aktual'nye voprosy anglijskoj filologii (1997): 148-151.

2. Sablina, E. N. «Semanticheskie sposoby obogashhenija sinonimicheskih rjadov v leksike social'nogo dialekta.» Avtoref. dis. kand. filol. nauk (Moskva, 1982).

3. Uvarov, Ju. P., Grineva, E. F., Gromova, T. N. Slovar' razgovornoj leksiki francuzskogo jazyka (Moskva, Prosveshhenie, 1988), 139.

4. Zjeldin, T. Vse o francuzah, per. s franc (Moskva, Progress, 1989), 439.

5. Elistratov, V. S. «Argo i kul'tura.» Slovar' moskovskogo argo: Materialy 19801994 gg. (Moskva, Russkie slovari, 1994), 700.

6. Bondaletov, V. D. Social'naja lingvistika (Moskva, Prosveshhenie, 1987), 159.

7. Hovanskaja, Z. I. Stilistika francuzskogo jazyka (Moskva, Vysshaja shkola, 1984), 344.

8. Tumanjan, Je. G. «Ponjatie «jazykovaja norma» s pozicij social'noj lin- gvistiki.» Problemy jazykovoj zhizni Rossijskoj Federacii i zarubezhnyh stran (1994): 120123.

9. Popova, Z. D., Sternin, I. A. Polevye struktury v sisteme jazyka (Voronezh, Izd-vo VGU, 1989), 198.

10. Gadet, F. Le français populaire (Paris, PUF, 1992), 128.

11. Calvet, L.-J. La sociolinguistique (Paris, 1993), 127.

12. François-Geiger, D. «Argots: la cohabitation.» Europe 738 (1990): 30-35.

13. Guilbert, L. «Peut-on definir un concept de norme lexicale?» Langue française 16 (Paris, Larousse, 1972): 29-48.

14. Chilikina, O. N. «Nekotorye osobennosti francuzskoj razgovornoj rechi.» Teorija $i$ istorija germanskih $i$ romanskih jazykov $v$ sovremennoj vysshej shkole Rossii (2002): 28-32.

15. Krysin, L. P. «O rechevom povedenii cheloveka v malyh social'nyh obshhnostjah: Postanovka voprosa.» Jazyki lichnost' (Moskva, Nauka, 2002): 78-86.

16. Koseriu, Je. «Sinhronija, diahronija i istorija.» Novoe v lingvistike 3 (1963), 568.

17. Gak, V. G. «Norma i tolerantnost'.» Inostrannye jazyki v shkole 1 (1984): 7-15.

18. Helgorski, F. «La notion de norme en linguistique.» Le français modeme 1 (1982): 1-14. 


\section{MICT}

\section{Голубовська І. О., Дарчук Н. П., Черненко А. А.}

Дослідницький проект: Мова і дискурсивні практики світового медіапростору у контексті змін аксіологічних домінант

\section{Голубовська І. О.}

Як вивчається та досліджується грецька мова в Україні (з нагоди

Міжнародного дня грецької мови 9.02.19.) [How Greek Language is Studied and Researched in Ukraine (on the occasion of International Greek Language

Day 9.02.19.)] 26

\section{Васильєва Т. О.}

Морбіальна метафора в економічному дискурсі сучасних іспаномовних 3MI

Гриценко С. П.

Статика і динаміка мови: проблеми рівноваги 48

Довбищенко Ф. В.

Авторська наративна стратегія в I книзі твору Ксенофонта "Виховання Kipa”

Заєць В. Г.

Дериваційна парадигма дієслова (на матеріалі художньої прози С. Гуцала)

Ковальова О. К.

Дискурс та функціональний стиль: проблема співвідношення 106

Коренькова О. А.

Лексико-семантична класифікація дієслів гносичного психічного стану в українській, німецькій та англійській мовах

Крисальна Ю. В.

Лінгвокультурний концепт $F A S H I O N$ крізь призму релігійної концептосфери (на матеріалі сучасних англомовних медіаресурсів) ......134

Лазер-Паньків О. В.

Особливості давньогрецьких фразеологізмів із компонентом-дендронімом 
Левко О. В., Чухно Ю.

Вербалізація мізогіністичних уявлень у давньогрецьких пареміях 173

\section{Лепетюк I. Г. [Lepetiuk I.]}

Функції мовленнєвих жанрів в текстах французьких романів XX ст. [Le fonctionnement des genres du discours dans les textes des romans du XX s.] 184

Милик О. В.

Номінативне поле субконцепту SANITAS в латинській мові .203

\section{Москвичова О. А.}

Поетичний текст як специфічний засіб відтворення дійсності

Трищенко I. B.

Функціонування алюзійних імен в художньому тексті .228

Хайдар Д. М.

Поняття мовної норми та французької літературної мови 3 позиції соціолінгвістики 


\section{CONTENT}

\section{Golubovska I., Darchuk N., Chernenko H.}

Research Project: Language and Discourse Practices of World Media in the Context of Axiological Dominants' Change

\section{Golubovska I.}

How Greek Language is Studied and Researched in Ukraine (on the occasion of International Greek Language Day 9.02.19.) 26

\section{Vasylieva T.}

Morbial Metaphor in Economic Discourse of the Modern Hispanic Media .....30

\section{Gritsenko S.}

Statics and Dynamics of the Language: the Issue of Balance

\section{Dovbyshchenko F.}

The Author's Narrative Strategy in the Book I of Xenophon's "Cyropaedia" ...

\section{Zaiets V.}

The Derivational Paradigm of the Verb (on the Material of E. Hutsalo Fiction Prose)

\section{Kovalova O.}

Discourse and Functional Style: the Problem of the Correlation 106

\section{Korenkova $\mathbf{O}$.}

Lexical-Semantic Classification of Cognitive Psych Verbs in Ukrainian, German and English

\section{Krysalna Y.}

The Concept of FASHION within the Cognitive Framework of Religion (Based on Contemporary English Media)

\section{Lazer-Pan'kiv $O$.}

Peculiarities of Ancient Greek Proverbs with Dendronym Component 


\section{Levko O., Chukhno Yu.}

Verbal Representation of Misogynistic Ideas in Ancient Greek Proverbs 173

\section{Lepetiuk I. [Lepetiuk I.]}

The Functions of Speech Genres in the French Novel of XX c. [Le fonctionnement des genres du discours dans les textes des romans du XX s.] 184

Mylyk O.

Nominative Field of the Subconcept SANITAS in the Latin Language .203

\section{Moskvichova 0.}

Poetical Text as the Specific Way of the Reflection of Reality

\section{Tryshchenko I.}

Functioning of Allusive Names in Literary Discourse .228

\section{Khaidar D.}

Language Standard and French Literary Language According to

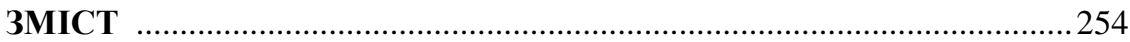

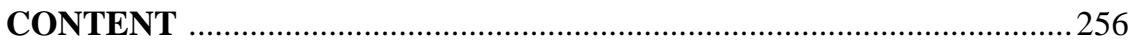

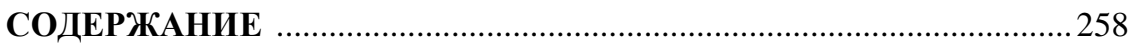

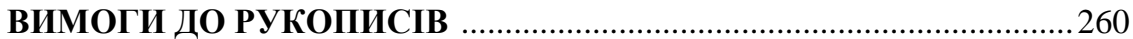

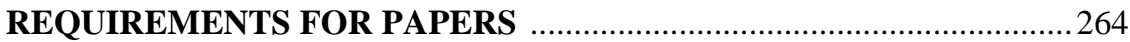

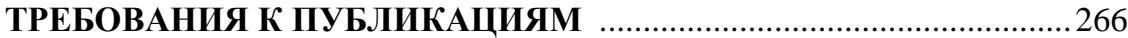




\section{СОДЕРЖАНИЕ}

Голубовская И. А., Дарчук Н. П., Черненко А. А.

Исследовательский проект: Язык и дискурсивные практики мирового медиапространства в контексте изменений аксиологических доминант ....9

\section{Голубовская И. А.}

Как изучается и исследуется греческий язык в Украине (по случаю Международного дня греческого языка 9.02.19.) ........................................26

\section{Васильева Т. А.}

Морбиальная метафора в экономическом дискурсе современных

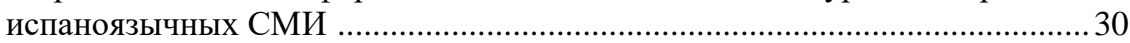

\section{Гриценко С. П.}

Статика и динамика языка: проблемы равновесия .48

\section{Довбищенко Ф. В.}

Авторская нарративная стратегия в I книге произведения Ксенофонта "Воспитание Кира"

\section{Заец В. Г.}

Деривационная парадигма глагола (на материале художественной прозы Е. Гуцало)

Ковалева Е. К.

Дискурс и функциональный стиль: проблема соотношения 106

\section{Коренькова А. А.}

Лексико-семантическая классификация глаголов гностического психического состояния в украинском, немецком и английском языках ....

\section{Крисальная Ю. В.}

Лингвокультурный концепт FASHION сквозь призму религиозной концептосферы (на материале современных англоязычных медиаресурсов) 
Лазер-Панькив О. В.

Особенности древнегреческих фразеологизмов с компонентомдендронимом

\section{Левко А В., Чухно Ю.}

Вербализация мизогинистических представлений в древнегреческих паремиях 173

\section{Лепетюк И. Г. [Lepetiuk I.]}

Функции речевых жанров в текстах французских романов XX ст. [Le fonctionnement des genres du discours dans les textes des romans du XX s.] ...

Мылык О. В.

Номинативное поле субконцепта SANITAS в латинском языке 203

Москвичёва О. А.

Поэтический текст как специфический способ отображения действительности

\section{Трищенко И. В.}

Функционирование алюзивных имен в художественном тексте .228

Хайдар Д. М.

Понятие языковой нормы и французского литературного языка с позиции социолингвистики

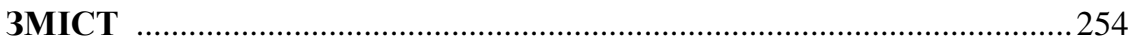

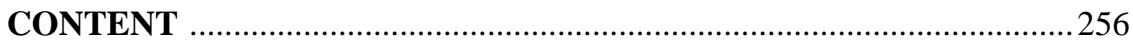

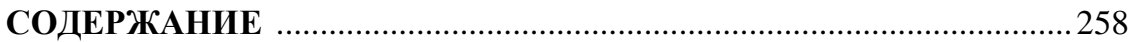

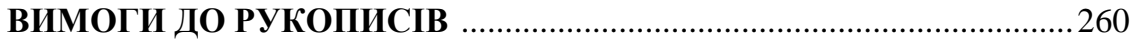

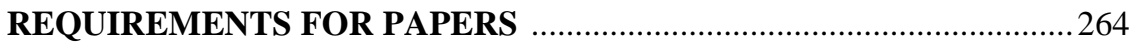

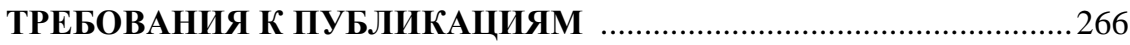




\section{ВИМОГИ ДО РУКОПИСІВ}

для публікації у фаховому збірнику наукових праць "STUDIA LINGUISTICA" (2018 рік)

ISSN 2411-1562

(кафедра загального мовознавства, класичної філології та неоелліністики)

Інституту філології

Київського національного університету імені Тараса Шевченка; м. Київ, 01033, бульвар Т. Шевченка, 14, каб.141; тел. 8 (044) 239-34-15; e-mail: zagmoclasphil@gmail.com)

Збірник наукових праць "Studia Linguistica" є фаховим виданням із дисциплін філологічного (мовознавство) профілю. Наказ Міністерства освіти і науки України № 747 від 13.07.2015 p.

Редакція фахового збірника наукових праць "Studia Linguistica" розглядає подані до друку матеріали (статті, рецензії, хроніки тощо) від спеціалістів у галузі лінгвістики за умови, що подані рукописи не публікувалися раніше, відповідають проблематиці збірника та оформлені відповідно до вимог.

1. Матеріали для публікації приймаються від спеціалістів у галузі лінгвістики. Мови публікацій: українська, російська, англійська, німецька, французька, румунська, польська.

2. Обсяг публікації - 0,5 друк. арк. (від 8 до 12 повних сторінок, включаючи літературу).

3. Над назвою ліворуч зазначається номер УДК. поряд з УДК зазначається розділ, в якому має бути розміщено статтю:

Проблеми загального, порівняльно-історичного, типологічного та зіставного мовознавства

Проблеми класичної філології та неоелліністики

Проблеми когнітивної лінгвістики, лінгвокультурології та етнолінгвістики 
Проблеми лінгвокомунікативістики, дискурсології та прагмалінгвістики

Проблеми перекладознавства

Проблеми прикладної лінгвістики

4. Відцентрована назва статті друкується жирними ВЕЛИКИМИ ЛІТЕРАМИ через 1 інтервал (шрифт - Times New Roman, 14).

5. Нижче (через 2 інтервали) відцентровано жирним курсивом Прізвище, Ім'я, По батькові автора. Нижче через 1 інтервал звичайним курсивом по центру науковий ступінь та вчене звання (н-д, д-р філол. наук, проф.; канд. філол. наук, дои.; викл.; асист.; асп.; студ.); ще нижче через 1 інтервал відцентровано звичайним курсивом місие роботи або навчання (назва установи пишеться повністю, без скорочень) (шрифт - Times New Roman, 14). Нижче зазначається e-mail автора статті.

6. Нижче подається вступна анотація обсягом від 150 до 200 слів згідно з ДСТУ ГОСТ 7.9. та Ключові слова (максимум 5-6 слів) мовою самої статті. Друкується 13 шрифтом Times New Roman через 1 інтервал курсивом (слово Анотація не писати, а слова Ключові слова: писати після анотації $з$ нового рядка).

7. Нижче подаються назва статті, ім'я автора та вступні анотації обсягом від 150 до 200 слів і ключові слова російською та англійською мовами. Якщо стаття написана російською або англійською мовами, то ім'я автора, назва публікації, анотації та ключові слова подаються обов'язково українською та однією із затверджених редколегією іноземних мов (друкуються шрифтом Times New Roman 13 через 1 інтервал (слова Аннотация або Summary не писати, а слова Ключевые слова, Key words: писати після анотації з нового рядка курсивом).

8. Основний текст рукопису друкується через 1,5 інтервали, шрифт Times New Roman 14, без переносів. Поля вгорі, внизу - 2 см, ліворуч - 2,5 см, праворуч - 1,5 см; відступ абзацу - 1,25 см (виставляти автоматично).

9. Фрагменти рукописів, що слугують ілюстративним матеріалом, друкуються курсивом.

10. Чітко диференціювати тире і дефic. Значення слів, виразів тощо беруться в лапки (лапки повинні бути тільки відкритими “ та закритими ”).

11. На початку статті обов'язково повинні визначатися актуальність, мета, предмет, об'єкт, наукова новизна дослідження. 3 постанови президії ВАК України від 15 січня 2003 р. № 7-05/1 “Про підвищення вимог до фахових видань, внесених до переліків ВАК Украйни” п. 3. Редакційним колегіям 
організувати належне рецензування та ретельний відбір статей до друку. Стаття повинна містити такі структурні елементи: 1. Вступ (постановка проблеми у загальному вигляді та їі зв'язок із важливими науковими та практичними завданнями, аналіз останніх наукових публікацій з теми дослідження, її актуальність). 2. Об'єкт і предмет, мета і завдання дослідження. 3. Виклад основного матеріалу дослідження. 4. Висновки та перспективи подальших розвідок. 5. Література (оформлена згідно 3 вимогами ДАК України). 6. Список джерел ілюстративного матеріалу (за наявності). 7. References (оформлені згідно з вимогами зарубіжних стандартів).

12. Посилання в тексті оформлюються таким чином: у квадратних дужках $з$ посиланням на прізвище і рік видання, номер сторінки вказується після коми, наприклад [Голубовська 2004, с. 94], [Бацевич 2003, с. 37-56; Freeman 2000, p. 254].

13. Перед крапками, комами, двокрапками, крапками 3 комами, знаками питання та оклику, а також після дужки та лапок не ставити пропусків.

14. Використані наукові джерела подаються після тексту у рубриці Література (відцентрована назва, жирним шрифтом, Times New Roman 14), в алфавітному порядку. Бібліографічний опис складається згідно з Chicago Style: Notes and Bibliography. 3 абзацу 1,25 см починається перше джерело. Шрифт Times New Roman 12, 1 інтервал. Кожна позиція списку літератури подається 3 нового рядка. Спочатку подавати в переліку за алфавітом видання російською та українською мовами, потім - іноземними (теж за абеткою). Усі роботи одного автора потрібно вказувати за зростанням років видання.

15. Список джерел ілюстративного матеріалу оформлюється згідно 3 вимогами до списку Літератури, за нумерацією продовжує список літератури.

16. Список літератури під заголовком References (відцентрована назва, жирним шрифтом, Times New Roman 14), в якому посилання оформлюються згідно з вимогами зарубіжсних стандартів та подаються для кирилиці у вигляді транслітерації за допомогою програми BGN (Board of Geographic Names), що представлена на сайті: http://www.translit.ru та 3 перекладом на англійську мову у квадратних дужках. Список повинен повторювати у своїй послідовності список Літератури та Список джерел ілюстративного матеріалу. Якщо в списку є посилання на іноземні публікації, вони повністю повторюються. 
Схема бібліографічного посилання:

- автор (и) (транслітерація);

- назва статті (транслітерація);

- [переклад назви статті англійською мовою у квадратних дужках];

- назва українського або російського джерела (транслітерація);

- [переклад назви джерела англійською мовою у квадратних дужках - парафраз (для журналів можна не робити)];

- вихідні дані $з$ позначеннями англійською мовою, або тільки цифрові;

- позначення мови статті (In Ukr. / In Russ).

\section{Приклад опису статті:}

Golubovs'ka, I. O. «Klasychni movy u konteksti suchasnogo movoznavstva: epistemy, metamova, instrumentarij [Classical Languages in the Context of Modern Linguistics: Epistemes, Metalanguage, Linguistic Devices].» Studia Linguistica 8 (2014): 3-10 (In Ukr.).

17. Після References подається дата надходження авторського оригіналу до редколегії. Шрифт Times New Roman 10.

18. Вартість однієї сторінки публікації - 50 гривень.

19. Для аспірантів та авторів без наукового ступеня обов'язковою $\epsilon$ рецензія на статтю наукового керівника або доктора філологічних наук.

20. Статті проходять рецензування та перевіряються на плагіат. У разі виявлення порушення видавничої етики статтю не рекомендують до друку. Статті приймаються тільки за умов дотримання редакційних вимог.

21. На окремому аркуші подати відомості про автора статті:

22.

- Прізвище, Ім'я, По батькові;

- посада та місие роботи або навчання;

- науковий ступінь та вчене звання;

- адреса, телефон, е-таіl.

Дата надходження статті до редакиії 13.10.2018 


\section{REQUIREMENTS FOR PAPERS in periodical \\ "STUDIA LINGUISTICA" (ISSN 2411-1562) \\ Chair of General Linguistics, Classical Philology and Neohellenic Studies, Institute of Philology, Taras Shevchenko National University of Kyiv, Ukraine e-mail: zagmoclasphil@gmail.com}

The Journal invites papers (including articles, reviews, opinions, etc.) from scholars in the field of linguistics. Papers are acceptable for publication on condition they have never been published before; their topics are relevant to the "Studia Linguistica" research focus and the text is presented in a predetermined format. Papers must describe the current state of the investigated problem and comprise the new findings revealed in the course of research.

Theoretical approaches must be supported by the appropriate illustrations.

1. Languages - Ukrainian, Russian, English, French, German, Romanian, Polish.

2. Paper must consist of: 0,5 p. p. for an analytical article; 0,3 p. p. for an article; 0,25 p. p. for a review.

3. Above the title on the left indicate the Universal Decimal Classification Index (UDC). Near the UDC - note section, whithin which the article might be placed:

Problems of general, comparative and historical, typological linguistics

Problems of classical philology and neohellenic studies

Problems of cognitive and cultural linguistics, ethnolinguistics

Problems of linguistic communication and discoursology

Problems of translation studies

Problems of applied and mathematical linguistics

4. Title of the article is printed in the center in 1 space (font - Times New Roman 14, bold CAPITALS).

5. Below (after 2 intervals) centered in bold italics Last Name, First Name of the author. Below 1 interval ordinary italics centered academic degree and academic title (PhD, assistant (associate) professor, postgraduate student, etc.). 1 interval below on the center place of work or study (institution name is written in full, without abbreviations; font - Times New Roman 14, ordinary italics). Below is the author's e-mail.

6. Instructions for preparation abstracts or summary: Three abstracts before the text of article sized from 150 to 200 words $\left(1^{\text {st }}-\right.$ in original language, $2^{\mathrm{d}}-$ in Ukrainian, $3^{\mathrm{d}}$ - in English or one of the journal's language - see p. 1) are to be found below followed by the key words ( 5 or 6 ) after each. The Second name of the author and his initials are placed before the abstracts, typed in bold (13 pt.). Institutional affiliation is on the next line in italics (13 pt.). The title is typed in bold (13 pt.) on abstract's language. Abstracts and Key words must be typed in Times New Roman 13 pt., ordinary italics in 1 space.

7. Paper format: the text must be typed in Times New Roman 14 pt. in 1.5 space in regular font with no hyphens at the end of line. Margins - at the top and bottom $-2 \mathrm{~cm}$; left $-2,5 \mathrm{~cm}$; right $-1,5 \mathrm{~cm}$. Paragraph indention $-1,25 \mathrm{~cm}$. Any extra fonts used in the paper must be supplied separately, like characters and illustrations.

8. Fragments of the paper containing illustrations must be typed in italics. 
9. Quotes and definitions are enclosed in quotation marks ("word"). A hyphen (-) must be clearly distinguished from a dash (-), e.g.: "Language - is ...", but "lexicogrammatical meaning".

10. Topicality, aim, and objectives of the study must be placed in the introductory part of the paper, typed in a light font and underlined. A scientific paper must include final or intermediate results of the study. A paper submitted for publication must be completed and comprise the following mandatory elements: 1. Introduction (problem statement indicating its connection with the important scientific and practical objectives). Analysis of recent researches and publications cited by the author. 2. Identification of the study's goal and objectives. 3. Presentation of the research supported by detailed illustration of the theses. 4. Conclusions and prospects of further investigation in the field. 5. Literature. 6. References illustrative material (if any).

12. All citations are given in square brackets, e. g. [Brown 2004, p. 94]. Citation of a series of works of the same author or several authors is marked by a semicolon, e. g.: [Grice 2003, p. 37-56; Freeman 2000, p. 254]. If pages are indicated from ... to ..., these are separated by a dash $(-)$, not a hyphen $(-)$. Temporal segments are presented likewise: XII-XIII c.

\section{Sources:}

The bibliography follows the text, including the list of reference sources. The word. "Literature" is typed after the text and centered. If necessary, List of Illustrative Material is included continuing the numbering from the previous list.

14. Scientific sources are submitted after the text within the heading Literature (centered, in bold, Times New Roman 14), in alphabetical order. Bibliographic description should be done according to Chicago Style: Notes and Bibliography. The first source begins with step back in $1.25 \mathrm{~cm}$. Font Times New Roman 12, one interval. Each position of the list of references is submitted beginning from a new line. First come editions in Russian and Ukrainian languages in alphabetical order, after - in foreign languages (also in alphabetical order). Works of one and the same author should be given in order of ascending years.

\section{Instructions for paper submission.}

The editorial board accepts:

- information about the author on a separate sheet and in a separate file including: full first and second names, patronymic name, degree, rank, place of employment or training (postgraduates should indicate the year of training), position, phone numbers, home and e-mail addresses;

- review of the submitted paper by the scientific supervisor for a postgraduate.

All materials are submitted in a folder, indicating the date of their reception by the editorial board. The electronic copy of the article and information about the author are sent to: zagmoclasphil@gmail.com

Papers submitted to the editorial board, including those not accepted for publication, will not be returned to the author.

16. The cost of one page of publication $-2 \$$. Payment is made after reviewing the article and checking it out for plagiarism.

Date of the acception by the Editorial Board 13.10.2018.

$\overline{\text { REQUIREMENTS FOR PAPERS }}$ 
STUDIA LINGUISTICA, 2018. - Vol. 13 : 266-268

\section{ТРЕБОВАНИЯ К РУКОПИСЯМ ДЛЯ ПУБЛИКАЦИИ В СБОРНИКЕ НАУЧНЫХ ТРУДОВ "STUDIA LINGUISTICA" (2018 год) \\ ISSN 2411-1562}

(кафедра общего языкознания, классической филологии и неоеллинистики Института филологии

Киевского национального университета имени Тараса Шевченка; г. Киев, 01033 , бульвар Т. Шевченка, 14, каб.141; тел. 8 (044) 239-34-15; e-mail: zagmoclasphil@gmail.com)

Сборник научных трудов "Studia Linguistica" является специализированным изданием в области дисциплин филологического (языкознание) профиля. Приказ Министерства образования и науки Украины № 747 от 13.07.2015 г.

Редакция сборника научных трудов "Studia Linguistica"

рассматривает представленные к печати материалы (статьи, рецензии, хроники и т.д.)

от специалистов в области лингвистики при условии, что предоставленные рукописи

не были опубликованы ранее, соответствуют проблематике сборника

и были оформлены в соответствии с выдвигаемыми требованиями.

1. Материалы для публикации принимаются от специалистов в сфере лингвистики. Языки публикации: украинский, русский, английский, немецкий, французский, румынский, польский.

2. Объем публикации - 0,5 печат. л. (от 8 до 12 полных страниц, включая литературу).

3. Над названием слева указывается номер УДК. Рядом с УДК - отмечается раздел, в котором должна быть размещена статья:

Проблемы общего, сравнительно-исторического, типологического и сопоставительного языкознания

Проблемы классической филологии и неоеллинистики

Проблемы когнитивной лингвистики, лингвокультурологии и этнолингвистики

Проблемы лингвокоммуникативистики, дискурсологии и прагмалингвистики

Проблемы перевода

Проблемы прикладной лингвистики

4. По центру название статьи печатается жирными БОЛЫШИМИ БУКВАМИ через 1 интервал (шрифт - Times New Roman, 14).

5. Ниже (через 2 интервала) по центру жирным курсивом Фамилия, Имя, Отчество автора. Ниже через 1 интервал обычным курсивом по центру научная степень и ученое звание (н-р, д-р филол. наук, проф.; канд. филол. наук, доц.; препод.; ассист.; асп.; студ.); еще ниже через 1 интервал по центру обычным курсивом место роботы или обучения (название учреждения пишется полностью, без сокращений) (шрифт - Times New Roman, 14). Ниже указывается e-mail автора статьи.

6. Ниже подается аннотация объемом от 150 до 200 слов согласно с ДСТУ ГОСТ 7.9. и Ключевые слова (максимум 5-6 слов) языком самой статьи. Печатается 13 шрифтом Times New Roman через 1 интервал курсивом (слово Аннотаиия не писать, а слова Ключевые слова: писать после аннотации с новой строчки). 
7. Абзаца- 1,25 см (выставлять автоматически).

8. Фрагменты рукописей, Ниже указывается название статьи, имя автора и аннотация объемом от 150 до 200 слов и ключевые слова на русском и английском языках. Если статья написана на русском или английском языке, то имя автора, название публикации, аннотация и ключевые слова подаются обязательно на украинском языке и на одном из утвержденных редколлегией иностранном языке (печатается шрифтом Times New Roman 13 через 1 интервал). Слова Аннотация или Suтmary не писать, а слова Ключевые слова, Кеу words писать после аннотации с новой строчки курсивом.

9. Основной текст рукописи печатается через 1,5 интервала, шрифт Times New Roman 14 , без переносов. Поля вверху, внизу - 2 см, слева $-2,5$ см, справа $-1,5$ см; отступ которые служат иллюстративным материалом, печатаются курсивом.

10. Четко дифференцировать тире и дефис. Значение слов, выражений и т.п. заключаются в кавычки (должны быть только «открытыми» и «закрытыми»).

11. Вначале статьи обязательно определяются актуальность, цель, предмет, объект, научная новизна исследования. Из постановления президиума ВАК Украины от 15 января 2003г. №7-05 / 1 “О повышении требований $\kappa$ профессиональным изданиям, внесенным в перечень ГАК Украины”,, п.3.: Редакционным коллегиям организовать надлежащее рецензирование и тщательный отбор статей в печать. Статья должна содержать следующие структурные элементы: 1. Введение (постановка проблемы в общем виде и ее связь с важными научными и практическими задачами, анализ последних научных публикаций по теме исследования, ее актуальность). 2. Объект и предмет, цель и задачи исследования. 3. Изложение основного материала исследования. 4. Выводы и перспективы дальнейших исследований. 5. Литература (оформлена в соответствии с требованиями ВАК Украины). 6. Список источников иллюстративного материала (при наличии). 7. References (оформленные согласно требованиям зарубежных стандартов).

12. Ссылки в тексте оформляются следующим образом: в квадратных скобках со ссылкой на фамилию и год издания, номер страницы указывается после запятой, например [Голубовская 2004, с. 94], [Бацевич 2003, с. 37-56; Freeman 2000, с. 254].

13. Перед точками, запятыми, двоеточиями, точками с запятыми, вопросительными знаками и знаками восклицания, а также после скобок и кавычек пропуски на ставятся.

14. Использованные научные источники подаются после текста в рубрике Литература (по центру название, жирным шрифтом, Times New Roman 14), в алфавитном порядке. Библиографическое описание составляется согласно Chicago Style: Notes and Bibliography. C абзаца 1,25 см начинается первый источник. Шрифт Times New Roman 12, 1 интервал. Каждая позиция списка литературы подается с новой строки. Сначала подавать в списке по алфавиту издание на русском и украинском языках, затем - на иностранном (также в алфавитном порядке). Работы одного автора указываются по возрастанию года выпуска издания.

15. Список иллюстративного материала оформляется в соответствии с требованиями к списку Литературы, нумерация продолжает список.

16. B References (по центру название, жирным шрифтом, Times New Roman 14) ссылки оформляются в соответствии с требованиями зарубежных стандартов и подаются для кириллицы в виде транслитерации с помощью программы BGN (Board of 
Geographic Names), что представлена на сайте: http://www.translit.ru, далее следует перевод на_английский язык в квадратных скобках. Список должен повторять в своей последовательности список Литературы и Список иллюстративного материала. Если в списке есть ссылки на иностранные публикации, они полностью повторяются.

Схема библиографической ссылки:

- автор (и) (транслитерация);

- название статьи (транслитерация);

- [перевод названия статьи на английский язык в квадратных скобках];

- название украинского или русского источника (транслитерация);

- [перевод названия источника на английский язык в квадратных скобках (для названий журналов не обязательно)];

- исходные данные с обозначениями на английском языке, или только цифровые;

- обозначение языка статьи (In Ukr. / In Russ.).

\section{Пример описания статьи:}

Golubovs'ka, I. O. «Klasychni movy u konteksti suchasnogo movoznavstva: epistemy, metamova, instrumentarij [Classical Languages in the Context of Modern Linguistics: Epistemes, Metalanguage, Linguistic Devices].» Studia Linguistica 8 (2014): 3-10 (In Ukr.).

17. После References казывается дата поступления авторского оригинала в редколлегию. Шрифт Times New Roman 10.

18. Стоимость одной страницы публикации - 50 гривен.

19. Для аспирантов или авторов без научной степени обязательна рецензия на статью от научного руководителя или доктора филологических наук.

20. Статьи проходят рецензирование и проверяются на плагиат. В случае выявления нарушений издательской этики статья не рекомендуется к опубликованию. Статьи принимаются только при соблюдении редакционных требований.

21. На отдельном листке подается информация об авторе статьи:

- Фамилия, имя, отчество;

- долюнность и место работы или учебы;

- ученая степень и ученое звание;

- адрес, телефон, е-таіl.

Дата поступления статьи в редакциио 13.10.2018

Підп. до друку 30.11.2018. Формат 60×841ㅜㄹ. Папір. офс. Гарнітура “Таймс”. Друк. офс. Ум. друк. арк. 1,9. Обл.-вид. арк. 1,9. Наклад 100 прим. Зам. 575.

Віддруковано у ТОВ-Видавництві “ЛОГОС” із оригіналів автора.

Свідоцтво про внесення суб'єкта видавничої справи Державного реєстру видавців,виготівників і розповсюджувачів видавничої продукції серія ДК № 201 від 27.09.2000 р.01030, Київ-30, вул. Богдана Хмельницького, 10, тел. 235-60-03 